Universidad Nacional de La Plata

FACULTAD DE HUMANIDADES Y CIENCIAS DE LA EducacióN SeCRETARÍA DE Posgrado

\title{
Libros de arena, desiertos de horror: la narrativa de Roberto Bolaño
}

\author{
Paula Aguilar
}

Tesis para optar por el grado de Doctora en Letras

Directora Dra. Teresa Basile, UNLP

La Plata, 15 de octubre de 2013 
Soñábamos con utopía y nos despertamos gritando Roberto Bolaño, "Déjenlo todo"

Me dijo que su libro se llamaba el Libro de Arena, porque ni el libro ni la arena tienen ni principio ni fin Jorge Luis Borges, "El libro de arena"

Comprendieron que un libro era un laberinto y un desierto.

Que lo más importante del mundo era leer y viajar Roberto Bolaño, Los sinsabores del verdadero policía 


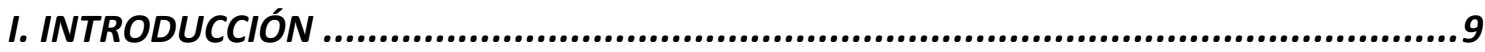

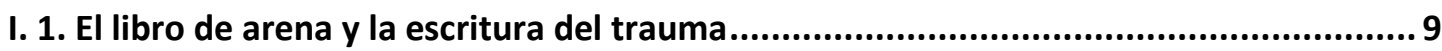

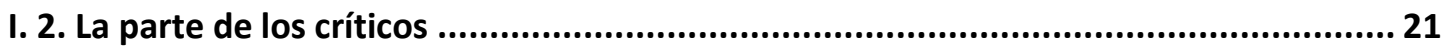

II. "PASILlO SIN SALIDA APARENTE": LA MEMORIA EN EL CHILE DE LA POSDICTADURA

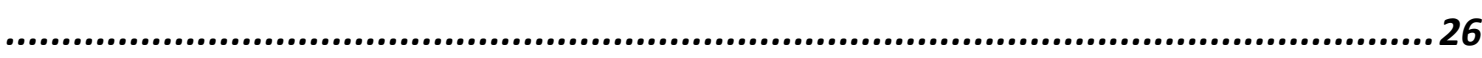

II. 1. La memoria bajo la dictadura: entre el testimonio y la hipervanguardia .................. 26

II. 2. La memoria en la democracia 'pactada' ................................................................ 30

II. 3. Intervención en la memoria pactada: la Revista de crítica cultural ...........................33

II. 4. "La herencia de Donoso es un cuarto oscuro", literatura en el Chile posdictatorial. . 37

III: FIGURAS DE ARTISTA: ESCRITURA Y VIDA, LITERATURA Y HORROR ...................43

III. 1. Malas vidas: historias particulares de infames ...................................................47

III. 2. Una temporada en el infierno: Estrella distante ...................................................56

III. 3. Bolaño est un autre: historias mínimas, grandes cuentos ......................................71

III. 4. Los detectives salvajes, fragmentos de una biografía de América Latina en su

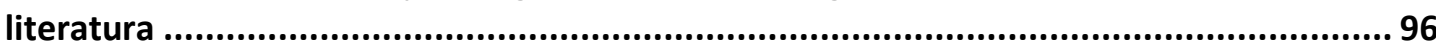

IV. LA MEMORIA EN LA TENSIÓN ENTRE TESTIMONIO Y FICCIÓN ...........................111

IV. 1. Testimonio y confesión. Literatura, melancolía y posdictadura (Nocturno de Chile)

IV. 2. Testimonio y fantástico. Relecturas de la tradición latinoamericana ..................... 125

Ni mágico ni maravilloso: el realismo visceral y las huellas del fantástico rioplatense ..............125

Del infrarrealismo al realismo visceral ..........................................................................136

V. EL POLICIAL: CRÍMENES DEL PASADO, HUELLAS DEL PRESENTE ....................... 174

VI. REINSCRIPCIONES DE LA MEMORIA EN EL PRESENTE DE AMÉRICA LATINA: 2666

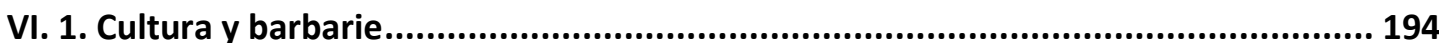

VI. 2. Desiertos de horror: América Latina, literatura y violencia .................................. 205

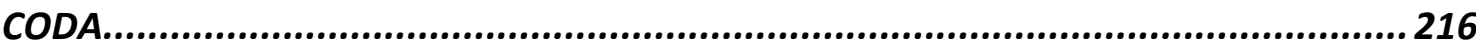

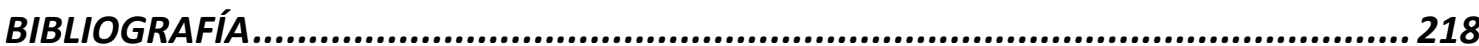




\section{Presentación}

Nuestro trabajo propone el análisis de la narrativa de Roberto Bolaño atendiendo a los principales debates en torno a los vínculos entre historia reciente y literatura que han marcado la agenda cultural y literaria de América Latina en los últimos años. Nos interesa explorar los aspectos centrales de su proyecto literario como una intervención en el espacio enunciativo de la posdictadura en el Cono Sur en torno a los modos de narrar el horror de las últimas dictaduras militares. La cuestión de la memoria se coloca en un espacio privilegiado del campo cultural para examinar los restos del pasado traumático desde diferentes aristas, como los tópicos de la derrota, el duelo y la melancolía que forman parte de los reflexiones abiertas con las transiciones democráticas para pensar la historia reciente. Desde la literatura, la pregunta por los modos de narrar el horror postula diferentes opciones estéticas y perspectivas desde las cuales abordar las representaciones de la violencia: como las (im)posibilidades de la representación (Adorno), las posibilidades del testimonio (Levi, Agamben), el lugar de la ficción y la autoficción o los desplazamientos y reescrituras de géneros literarios, entre otros. Los aportes de la crítica especializada en torno a la Shoá sirven de marco y antecedente a los debates más localizados en el Cono Sur de las experiencias latinoamericanas que desde las ciencias sociales y la crítica cultural abordan los usos y significaciones de la memoria (Jelin, Vezetti, Richard), las (im)posibilidades del duelo y la melancolía (Gundermann, Avelar, Moreiras) entre otros núcleos de discusión centrados en leer el fin de siglo XX en América Latina atravesado por la violencia de la historia. Las alternativas estéticas que despuntan en el nuevo escenario manifiestan un impulso renovador a partir de la reescritura y el desplazamiento de las tradiciones literarias. En este marco, se reciclan diferentes géneros literarios para dar cuenta de una experiencia determinada por el horror, la pérdida y el trauma. En este sentido, proponemos explorar las particularidades de la "escritura del trauma" que Bolaño pone en práctica y focalizamos nuestro análisis en tres modalidades estéticas que adquieren importancia y en los noventa presentan particularidades que impiden cristalizarse en géneros: tales son "el policial", "el fantástico" y las denominadas "escrituras del yo".

Para leer la narrativa de Roberto Bolaño en este contexto es necesario sondear las particularidades del campo cultural y literario chileno con el cual dialoga, aun en términos negativos. Es decir, para sustraer a Bolaño de los límites locales de discusión 
se vuelve necesario recortarlo de las líneas estéticas integrada por los polos de la vertiente testimonial y la hipervanguardia, y por la denominada "Nueva narrativa chilena". Esto constituye un primer paso para colocar a Bolaño en un lugar privilegiado de la literatura latinoamericana reciente. Así, otro eje fundamental de nuestro análisis consiste en evaluar su propuesta narrativa como una lúcida intervención en los cambios que en la tradición literaria latinoamericana se gestan desde los sesenta hasta los noventa y principios del siglo XXI. Para lo cual indagamos en los debates en torno a los nuevos realismos o realismos adjetivados que han dado lugar a una serie de estudios críticos (como los de Cánovas, Gramuglio, De Diego, Contreras, Chiani, Dalmaroni) que permiten repensar los modos en que la literatura reelabora América Latina. Así, proponer, con Bolaño, un "realismo visceral" como posibilidad estética implica dinamitar en el interior de la literatura latinoamericana más canonizada, la del boom, para quebrantar todo mito de totalidad asociado a una posible identidad continental de tintes optimistas y para ir contra toda imagen que estanque la esencia exclusiva de lo latinoamericano como una identidad otra, fabulosa o exótica. Bolaño articula una escritura visceral, sin épica, cuyo paisaje emblemático es el desierto, y la cartografía que arma no tiene que ver con el frenesí revolucionario que conectó América Latina con Europa en la década de los sesenta sino con las escenas de barbarie y horror que instalaron las guerras, las dictaduras, los totalitarismos -y que también unen ambos continentes.

En la Introducción planteamos la posibilidad de leer la obra narrativa completa de Roberto Bolaño más allá de un ordenamiento cronológico, atendiendo a su arquitectura hipertextual que posibilita múltiples entradas y salidas, un rasgo que bajo la metáfora borgeana del "libro de arena" juega con la posibilidad del infinito, antes que con la idea de totalidad. La presencia de Jorge Luis Borges en la narrativa de Bolaño retorna una y otra vez, de modo que comenzar con una imagen borgeana y sus derivas nos parece una opción hasta imaginada por el mismo Bolaño. Además, el libro de arena también instala otro rasgo recurrente en los textos del escritor chileno: el horror. En "Avatares de la Tortuga" Borges escribe: "Hay un concepto que es el corruptor y el desatinador de los otros. No hablo del Mal cuyo limitado imperio es la ética; hablo del infinito" (1932, en Discusión, OC: 254). Si Borges anhela una "ilusoria biografía del infinito" (254), Bolaño explora el más limitado territorio del Mal. No se detiene en conjeturas filosóficas o matemáticas porque el desasosiego de la historia se impone y es 
a partir de las reflexiones en torno a los vínculos entre historia y literatura, entre el mal y la escritura, entre la civilización y la barbarie que abordamos su narrativa. La figura de Borges, además, se instala entonces como epicentro del huracán Bolaño para dar cuenta de las posibilidades universales e infinitas de la literatura por encima de fronteras geoculturales; sin embargo para Bolaño, a diferencia de Borges (más argentino), el puerto de partida siempre es América Latina.

El Capítulo 1 reseña alguno de los trabajos más importantes que la crítica ha producido en los últimos años marcados por la "epidemia" (Volpi), el "mito" (Castellanos Moya) de Bolaño. De los pioneros volúmenes compilados por Celina Manzoni y Patricia Espinosa a las tesis de doctorado publicadas en diferentes países, la obra de Bolaño ha suscitado innumerables lecturas. Los pioneros trabajos hacen eco de la urgencia de leer y mostrar un proyecto estético innovador y excéntrico. Finalizando la primera década del nuevo siglo, nuevos aportes se presentan contra los lugares comunes que atrapan a Bolaño en cuestiones de contenido y lo posicionan como un nuevo representante del exotismo latinoamericano, y contra miradas esencialistas se abren nuevas lecturas enmarcadas en las discusiones sobre el mercado mundial (Sánchez Prado, Corral). En este capítulo establecemos un "estado de la cuestión” de la crítica actual sobre la literatura de Roberto Bolaño para desde allí proponer los alcances de nuestra perspectiva de análisis.

En el Capítulo 2 postulamos la necesidad de enmarcar su producción en el escenario de los debates en torno a las herencias de las últimas dictaduras latinoamericanas y para ello se vuelve necesario indagar las reflexiones sobre la memoria, asumiendo la singularidad del caso chileno. Así, las discusiones del campo cultural y literario chileno encarnan en diferentes voces, estéticas, proyectos y soportes discursivos (como la hipervanguardia y la Revista de crítica cultural, las Ciencias sociales y el testimonio, la "Nueva narrativa chilena") que funcionan como telón de fondo en el que la figura de Bolaño se recorta, irreverente y solitaria. Entre paréntesis (que recopila ensayos, reseñas, artículos y discursos de Bolaño) se presenta aquí como una intervención crítica que aborda la dimensión reflexiva sobre los avatares del escritor, la sustancia de la literatura y los temas luego ficcionalizados en sus cuentos y novelas, sobre sus "lugares en la literatura" y sus "lugares en la sociedad" (Gramuglio 1992: 37-64). Si es desde el interior de la democracia chilena "limitada" que Roberto Bolaño aborda con irreverencia ciertos nudos incómodos de la memoria, sin colocarse ni en la transparencia de la memoria testimonial, ni en la opacidad de la memoria 
nómada de la hipervanguardia chilena, su proyecto, sin embargo, se erige en un espacio más amplio de discusión que abarca un campo intelectual y literario latinoamericano atravesado por diversas propuestas sobre las cuales Bolaño apunta sus afinidades tácitas y sus rechazos explícitos respecto de sus pares.

En el Capítulo 3 se abordan las imágenes de escritor que atraviesan los textos de Bolaño desde los aportes teórico-críticos de las "escrituras del yo" y particularmente de la "autoficción” (Dubrosky, Alberca, Amícola). Las biografías ficcionales (especialmente de escritores y artistas) exploran la cuestión del mal y la violencia e interrelacionan el horror y el arte como una forma crítica de discutir la tradición y el canon. Como en La literatura nazi en América Latina cuyas disparatadas entradas biográficas de artistas réprobos hacen trizas las arbitrariedades y complacencias del campo literario ilustrado y canónico. Estrella distante continúa con estas vidas de artistas y criminales que incitan a reflexionar sobre arte, ética y política. También las figuras de autor que aparecen dispersas en los cuentos (Llamadas telefónicas, Putas asesinas, El gaucho insufrible y El secreto del mal) y en Los detectives salvajes pueden leerse desde la autoficción como imágenes y contraimágenes del escritor Roberto Bolaño, (cuyo nombre propio aparece derivado como "Bolaño", "Belano" y "B") que instalan un recorrido por el sistema literario latinoamericano reciente. Recuperamos las figuras de escritor para dar cuenta de la "biografía intelectual" de Bolaño a través de sus estancias en Chile, México y Barcelona. Desde la autoficción, el recorrido está marcado por el fuerte vínculo de la literatura con la revolución en los sesenta/setenta y se extiende hasta la centralidad del mercado en los noventa. Aquí, es importante explorar el lugar de la literatura y la condición del escritor a partir del quiebre provocado por las dictaduras militares.

El Capítulo 4 expande las posibilidades que las "escrituras del yo" ofrecen para explorar los avatares de la memoria y sus poéticas. La "confesión" y el "testimonio" se revelan así como instancias de diálogo con las tradiciones latinoamericanas que Bolaño recupera y socava para trazar su propio recorrido estético. En Nocturno de Chile el duelo y la melancolía articulan el problema de la memoria, el olvido, los silencios y complicidades a través de la confesión mentirosa de un cura y crítico literario que nuevamente desenmascara los vínculos entre arte y crimen. Amuleto y Monsieur Pain indagan los modos de narrar el horror desde un presente crepuscular que vincula otros acontecimientos de América Latina (como Tlatelolco) y otras experiencias, como los totalitarismos europeos (en especial la Alemania del nazismo y la España del 
franquismo) evitando estancarse en memorias locales. El testimonio reformulado por Bolaño desplaza el protocolo del género e incorpora nuevas aristas desde su estética visceral. Es pertinente entonces enmarcar esta relectura de la tradición latinoamericana del boom a la posdictadura a partir de los conceptos clave de las décadas anteriores: nos detenemos entonces en el realismo mágico, lo real maravilloso y el fantástico rioplatense.

En el Capítulo 5 exploramos cómo el género policial surge como otra posible matriz desde la cual sumergirse en los vínculos entre escritura y violencia a partir de la relación dialéctica entre lo cotidiano y el horror. Los usos del policial de Bolaño se enmarcan en las nuevas reapropiaciones del género que la narrativa latinoamericana realiza en los últimos años (la serie negra, el policial clásico o de enigma y el policial intelectual). Las marcas del género que Bolaño retacea permiten un juego que imprime un código al mismo tiempo que lo diluye, en un relato anclado entre los vaivenes de la "escritura del trauma" y el "trauma de la escritura" tal como veremos en La pista de hielo, Una novelita lumpen, Amberes y El Tercer Reich.

En el Capítulo 6 Bolaño da un giro en la perspectiva de la violencia extrema. Además de explorar el nazismo, 2666 aborda los problemas de la violencia desatada por el narcotráfico y el neoliberalismo. De este modo entonces fragua un pasaje de la violencia protagonizada por las dictaduras militares y los totalitarismos hacia esas violencias de nuevo signo que emergen en América Latina bajo el prisma neoliberal. Lo cual significa pasar del fin de siglo XX a inicios del siglo XXI, de un modo de violencia a otro. La novela constituye el último proyecto planificado del escritor (ante la inminencia del trasplante de hígado, que no llega a producirse), en ella se recupera la violencia como otro eje central (textualizado tempranamente en Consejos de un discípulo de Morrison a un fanático de Joyce) que supone un particular estado de la cuestión de la narrativa reciente en América Latina en el que vuelve a recuperar ciertos tópicos de la tradición del continente.

De este modo el recorrido a través de la obra narrativa completa de Bolaño nos permite ir a las experiencias de la violencia extrema y del mal radical centradas en las dictaduras del Cono Sur hacia la reciente (y no tan reciente) emergencia de nuevas formas en que la violencia (también infinita, también de arena) se hace presente en los femicidios de la frontera mexicana, en el narcotráfico y en los efectos del neoliberalismo en los noventa. 


\section{INTRODUCCIÓN}

El resto, más que una historia o un argumento, es un itinerario Roberto Bolaño, "El Ojo Silva"

\section{1. El libro de arena y la escritura del trauma}

La narrativa del escritor chileno Roberto Bolaño (Santiago de Chile, 1953Barcelona, 2003) ha adquirido importancia en el campo intelectual de América Latina en los últimos años, tanto en los círculos de escritores como en el público lector y en los medios académicos. Si en un comienzo su aceptación plena en Chile ha tropezado con algunas dificultades -ocasionadas por su visión crítica e irreverente de la tradición literaria chilena-, en cambio Bolaño ha logrado imponer cómodamente su literatura en América Latina y en España primero, en Estados Unidos y resto de Europa luego. Su temprana muerte y la publicación de su obra por la editorial Anagrama no han sido ajenas a ello.

Desde los pioneros volúmenes colectivos de Celina Manzoni (2002) y Patricia Espinosa (2003), el número de publicaciones en torno a la obra de Bolaño ha aumentado copiosamente. Estos primeros trabajos constituyen valiosos acercamientos pero, en tanto compilaciones, se detienen más en análisis particulares de las novelas que en recorridos mayores que pongan en relación la narrativa completa de Bolaño. Ocurre lo mismo en las cuidadosas ediciones de Edmundo Paz Soldán y Gustavo Faverón Patriau (2008), de Felipe Ríos Baeza (2010), de Fernando Moreno (2005 y 2011) y de Raúl Rodriguez Freire (2012). En los últimos años, han aparecido también nuevos trabajos críticos que abordan individualmente la escritura del autor (Bolognese, 2010; Poblete Alday, 2010; González, 2011) y una necesidad de renovación en las lecturas parece adherir a una deslocalización de Bolaño que brega por alejarlo de viejos clisés latinoamericanistas, tal es el tono del estudio de Wilfrido Corral (2011) sobre la recepción anglosajona de Bolaño, por ejemplo.

En un contexto acelerado donde las lecturas de Bolaño proliferan en diferentes formatos y medios (artículos, blogs, conferencias, coloquios, libros, etc.) nuestro trabajo 
surge de la necesidad de una perspectiva más amplia e integral sobre la obra del escritor, que retome ciertos núcleos, a la vez que transite otras vías posibles para articular una visión de obra completa que, lejos de implicar un cierre, intenta descubrir los pliegos de una obra abierta (Eco 1962).

Descartar una lectura que priorice un ordenamiento cronológico de los textos es sostener que la obra de Bolaño en tanto conjunto rechaza una lectura lineal o teleológica, para proponer una lectura en espiral porque cada texto remite, anticipa o retoma a otro, de modo que es posible leer la obra en su conjunto como un gran hipertexto narrativo. ${ }^{1}$ Es decir, como derivaciones de un texto a otro que en sus diferentes transformaciones pueden identificarse como injertos, según Gerard Genette (1989: 14). La metáfora es elocuente si tenemos en cuenta que los injertos se utilizan en botánica, por ejemplo- para permitir el crecimiento, propagar especies, es decir para proliferar, expandirse y jugar con el infinito. Con Borges, sabemos los peligros de pretender lo infinito. "El libro de arena", sin principio ni fin, reviste la idea de infinito con lo monstruoso, una puerta de acceso al caos como zona donde el ser humano se pierde, pues carece de las coordenadas para transitarla (o posee demasiadas coordenadas inútiles) pero que sin embargo cabe en un libro. ${ }^{2}$ El infinito y el mal no son cuestiones

\footnotetext{
${ }^{1}$ Ignacio Echeverría (1996) tempranamente propone, en su reseña sobre Estrella distante, el concepto de "fractalidad" para acercarse a los textos de Bolaño. El crítico español más tarde señalaría como su más notable característica el hecho de que "cualquiera sea el libro de Bolaño por el que empiece, ingresa el lector en un espacio común al que concurren todos los libros restantes" (2002: 45) y vuelve a insistir en la fractalidad como un efecto que permite leer la obra entera "como una especie de dispositivo articulable al que se van sumando nuevas piezas" (47). Incluso se ha propuesto como categoría para el análisis literario a partir de imágenes como el laberinto o las cajas chinas (Borges y Kafka serían sus referentes) además de adquirir casi las aristas de un movimiento (con su manifiesto correspondiente). Son intervenciones, en los bordes de la academia, que circulan en la web (Ver por ejemplo los sitios: http://literaturafractal.blogspot.com.ar/; o el "Manifiesto del fractalismo" en: http://www.galeon.com/fractalismo/ y el "Manifiesto Fractal" en http://jamillan.com/celpic.htm).

Creemos que lo fractal es útil como figura más que como categoría de análisis, pues los rasgos que se listan en los sitios mencionados remiten más a conocidos temas y procedimientos (especialmente desde la literatura fantástica más sistematizada por decirlo de alguna manera) que a una novedosa manera de leer. El espectro que rodea a esta idea de lo fractal supone nociones como recursividad, repetición, multiplicidad e incluso el rizoma que Gilles Deleuze y Félix Guattari derivan de la biología. La idea de hipertexto es, a nuestro criterio, la que más se aproxima al modo posible de lectura de la obra en su conjunto que proponemos. Coincidimos con Alexis Candia (2005) cuando afirma "que Bolaño intenta un palimpsesto total, un esfuerzo por disolver los límites entre sus textos y así buscar la totalidad paradójicamente desde el fragmento -para tejer una red de magia que construya un universo cerrado: el planeta Bolaño". Creemos necesario ir más allá de la descripción para poder descifrar las implicancias que dicho proyecto tiene, vislumbrar lecturas que lo expliquen. Ver también: Rojas Pachas (2009).

${ }^{2}$ Comienza el relato de "El libro de arena": "La línea consta de un número infinito de puntos; el plano, de un número infinito de líneas; el volumen, de un número infinito de planos; el hipervolumen, de un número infinito de volúmenes... No, decididamente no es éste, more geometrico, el mejor modo de iniciar mi relato" (Borges 1975).
} 
extrañas a Bolaño. ${ }^{3}$ Los personajes y motivos que va injertando en sus diferentes textos -y así transmigran de obra en obra- evitan su clausura porque cada texto se abre a otro. El procedimiento es también el de Julio Cortázar en el camino que va del capítulo 62 de Rayuela a la novela 62 pero el eco es borgeano, es la idea del texto como borrador, abierto a correcciones, a reescrituras, al infinito.

Por un lado, la noción de hipertexto nos permite aprehender los textos de Bolaño en su dimensión no secuencial sino en sus bifurcaciones. Esto no significa un texto fragmentario, descentrado o caótico pues el hipertexto implica un cierto orden que es establecido por el lector, quien elige dónde empezar y cómo proseguir la lectura. Partiendo de Genette, la teoría del hipertexto nutre las posibilidades de las nuevas tecnologías y abarca dos importantes líneas de análisis, la primera se circunscribe a aspectos técnicos que el nuevo medio -la world wide web- permite para organizar la información y la otra, incorpora -desde una perspectiva posestructuralista- los estudios de crítica y teoría literaria respecto de la noción de texto. Precisamente cuando George Landow (1992) explora el concepto de hipertexto lo hace converger con categorías propias de los estudios literarios desde Mijaíl Bajtin, Roland Barthes, Jacques Derrida y Jean Braudrillard y establece precursores literarios como el Ulises de James Joyce (y Finnegan's Wake, sobre todo), Tristram Shandy de Laurence Sterne, o Gravity's Rainbow de Thomas Pynchon.

Lo metaliterario o la intertextualidad son recursos asociados a las posibilidades del hipertexto, que permanecen al interior de la obra -aun cuando impliquen saltos, guiños 'hacia afuera'- pero lo que nos interesa resaltar es que la noción de hipertexto ofrece un modo de ver la narrativa completa de Bolaño en su conjunto, no sólo como una posibilidad de escritura sino también como un modo de lectura. De ahí, que la importancia al lector que Umberto Eco destacaba en la obra abierta vuelve a actualizarse con esta figura de hipertexto. ${ }^{4}$

\footnotetext{
${ }^{3}$ En "Avatares de la Tortuga" Borges escribe: "Hay un concepto que es el corruptor y el desatinador de los otros. No hablo del Mal cuyo limitado imperio es la ética; hablo del infinito" (1932, en Discusión, $O C:$ 254).

4 También, la metáfora de Borges del "libro de arena", con la cual nos quedamos, imprime varias inquietudes en el lector. La sensación de falta, o el resto que los textos liberan también trasluce la sospecha de que algo volverá a aparecer en otras páginas; el déjà vu experimentado al atravesar por diferentes obras es el otro lado de lo siniestro que permea algunos textos. Ni principio, ni fin: el universo Bolaño se rescribe tantas veces como se lee; personajes, motivos y atmósferas se escurren como granos de arena para volver a conformarse en el infinito impulso de reciclaje que proponen sus textos.
} 
Junto con los conceptos que permiten interpretar la narrativa de Bolaño en conjunto señalamos los procedimientos que arman este texto hipertextual basado en la recursividad y la reescritura. La "transmigración de personajes" es uno de los rasgos más visibles. Ramírez Hoffman, cuya vida se informa en las entradas biográficas desquiciadas de La literatura nazi en América reaparece con protagonismo absoluto en Carlos Wieder de Estrella distante. Igual deriva recorre Auxilio Lacouture quien expande las diez páginas de voz de Los detectives salvajes en una novela 'propia', Amuleto o el general Eugenio Entrescu que de una brevísima mención en La literatura nazi en América se convierte en protagonista de un relato intercalado en 2666. Personajes secundarios en novelas se apropian de algún cuento, como Lalo Cura (en Putas asesinas) cuya historia también conocemos en 2666 o Joanna Silvestri quien apenas aparece en Estrella distante y su perfil se completa en el cuento homónimo de Llamadas telefónicas.

A veces, la "condensación de argumentos" explosiona en otro texto, se distiende y completa como la biografía del personaje Amalfitano que se atisba en 2666 pero se completa en Los sinsabores del verdadero policía. Amalia Maluenda, la empleada mapuche de las hermanas Garmendia en Estrella distante, única testigo de los asesinatos cometidos por Carlos Wieder, será el germen de la voz de Auxilio Lacouture, otra sobreviviente, y ambas encarnan la memoria hilada de "la historia de terror", de homicidios e injusticias latinoamericanas.

Las "derivas del nombre Bolaño" a través de toda la obra constituye otro de los procedimientos de este hipertexto. Así, hay personajes escritores que ficcionalizan datos reconocidos de la biografía del autor Roberto Bolaño (el nombre propio se disemina como "Bolaño", "Belano", "B") y también hay narradores que asimismo comparten las mismas características (generalmente están anclados en los años de juventud -son poetas, son pobres- tal como leemos en algunos cuentos de Llamadas telefónicas y Putas asesinas, en Los detectives salvajes, o en Estrella distante).

A veces son ciertos "temas, tópicos e imaginarios" que retornan insistentemente, y hacen eco en los modos de armar el relato como los huecos que introduce el fantástico o las derivas del policial; o también, la constante reaparición de ejes que vertebran los textos, aún sesgadamente, y configuran el Hipertexto-Bolaño. Estas modalidades estéticas y tópicos redundan en lo siniestro, lo abismático, lo oculto y lo fantasmático un imaginario crepuscular que exploraremos en este trabajo. 
Este libro de arena de Roberto Bolaño que abordamos está regido por dos principios constructivos que son los que trazan vínculos internos en la economía organizativa hipertextual: por un lado, lo inconcluso y por el otro, lo retornable. Es posible vincular estos dos principios constructivos con la economía del trauma, es decir, las características de la discursividad del trauma se corresponden con la discursividad del Hipertexto-Bolaño. Ciertas obsesiones y recurrencias, como lo fragmentario e inconcluso de la escritura, pueden leerse a partir de una reflexión sobre el impacto de la experiencia de lo traumático y la necesidad de dar cuenta de ello. El trauma nombra una herida, un daño latente del pasado que afecta al sujeto y retorna compulsivamente en las vivencias actuales. El acontecimiento traumático manifiesta aquello que no es asimilado completamente en el momento en que sucede sino con retraso en su repetición (LaCapra 2001, 2008). Pero también el "olvido" latente es una posibilidad de la memoria ya que preserva el evento traumático en su literalidad, en su "acting out", su repetición compulsiva (Caruth 1991: 187, LaCapra 2008: 188). Esto genera una "escritura del trauma" que se erige a partir de la experiencia del mal radical y de la violencia extrema. ${ }^{5}$ De modo que la escritura está atravesada por una doble instancia definida por la experiencia de lo latente que aparece como una amenaza, que pugna por emerger. Esa presencia oculta del pasado se coloca como una inminencia, como un peligro que va a suceder (aunque ya aconteció). Así, se configura una escritura quebrada que da cuenta de la dificultad de la palabra en los modos de armar el relato. No se establece una continuidad explicativa, o se fracturan las secuencias lógicas, porque hay una fisura en el orden de la experiencia que corta el hilo del relato. Esto da lugar también a un imaginario melancólico porque el trauma se constituye como un estadio que no termina de elaborarse y el proceso de duelo no consigue suturar la herida abierta. El acontecimiento traumático genera una "escritura del trauma" y un "trauma de la escritura" tal como veremos en Amuleto, Una novelita lumpen o Amberes y vertebra además el relato de todo el Hipertexto-Bolaño en su conjunto. ${ }^{6}$

\footnotetext{
${ }^{5}$ LaCapra advierte contra la aplicación de conceptos del psicoanálisis en cuestiones relacionadas con la historia. Sin reducir las profundidades que los acontecimientos tienen en su dimensión política, económica o social los aportes del psicoanálisis (melancolía, duelo, trauma) suman posibilidades de análisis a la historiografía y a la teoría literaria (1995: ix). Como el libro de arena, el evento traumático "tiene lugar fuera de los parámetros de la realidad "normal", tales como la causalidad, la secuencia, el tiempo y el espacio. El trauma es, entonces, un evento que no tiene principio ni fin, ni antes, ni durante, ni después" (Laub 1992: 68-68, traducción nuestra).

${ }^{6}$ La idea que Sandra Contreras comparte respecto de su propio recorrido crítico para leer la narrativa de César Aira nos resulta sumamente reveladora en tanto permite conformar un relato que funcione como guía en la aproximación de una obra en su conjunto, no ya a partir de "su capacidad para demostrar, o estabilizar, u ordenar sino para hacer creer" (Contreras 2003:11). A partir de, en nuestro caso, las
} 
A diez años de la muerte de Roberto Bolaño, las piezas publicadas hasta ahora ${ }^{7}$ desde los juegos de apertura o multiplicación, sin detenerse ni clausurarse, confluyen en un centro hacia el que las partes se dirigen que se llama 2666. Esta novela póstuma refracta el universo bolañano y es hacia ella también donde convergen los caminos de lectura que proponemos en el presente análisis. Es decir, en nuestra acometida al Hipertexto-Bolaño el nodo principal lo constituye 2666 y es a partir de ella que las vías de acceso a otros textos se abren y confluyen. Percibimos cómo supo captar la radiografía panorámica de América Latina en el pasaje hacia el siglo XXI: entre un fin de siglo XX marcado por la violencia de la historia, sus traumas y las urgencias del pasado contra los olvidos del presente, y un presente (inicios del siglo XXI) en el cual la violencia emerge visceral en las ciudades, en las subjetividades asediadas por el mal que parece anclarse en el crimen, lo ilegal, la corrupción pero también en los sujetos, en sus lenguas, sus prácticas. 2666 involucra todo ese espectro (la memoria del pasado, la memoria del presente) y recupera los nudos más importantes de su proyecto abocado a recuperar y descomponer las bases de la tradición latinoamericana reciente. Bolaño sostiene la necesidad de revisar las estrategias locales de identificación en el marco de la desnacionalización (globalización, universalización, mundialización), pero con la apuesta a sostener que la literatura todavía sigue pensando a América Latina

En el gesto metodológico que aborda una obra en su conjunto, la lectura crítica que aquí proponemos fluye por diversos itinerarios para construir un recorrido propio (Dalmaroni 2009: 9), que atraviesa la obra de Bolaño realizando paradas puntuales en ciertos textos e integra este libro de arena a uno de los proyectos narrativos más originales de la literatura latinoamericana reciente. Es necesario en este punto incluir algunas cuestiones para precisar, tanto respecto de los textos abordados como de la tarea crítica iniciada.

Los textos de Bolaño interpelan, en cada página, las categorías de autor, obra y nación, por lo cual asumimos la recuperación de tales categorías sin prescindir de algunos procesos críticos que las han rearticulado para hilvanar los modos en que Roberto Bolaño se apropia de ellas, las rescata y también las vacía.

novelas, cuentos y ensayos de Roberto Bolaño, el texto-Bolaño, intentaremos entonces tramar un relato que lo narre, una lectura crítica que es también un "acto ficcional o de inventiva" como Panesi ha señalado (1994: 7), este relato estará anclado, como veremos, en los traumas de la historia y sus vínculos con la literatura.

${ }^{7}$ En homenaje al escritor, a diez años de su muerte, el CCCB (Centre de Cultura Contemporània de Barcelona) organizó la muestra “Archivo Bolaño. 1977- 2003” (del 5 marzo 2013 al 30 junio 2013) donde se exhibe solo el diez por ciento del legado literario que un laborioso Bolaño dejó en cuadernos y computadoras. 
Por un lado, la noción de autor inherente a todo estudio que emprenda la perspectiva de obra completa (hacemos la salvedad necesaria que en nuestro caso ésta se circunscribe a la narrativa) supone casi abiertamente la idea de consagración, de autor legendario que ha fraguado el Romanticismo y ha explotado - en todos los sentidos- la industria editorial contemporánea. Desde las incómodas, rebeldes o magnánimas figuras de autor construidas por los mismos escritores (de Lord Byron a Dylan Thomas, de Víctor Hugo a Arthur Rimbaud, Leopoldo Lugones, José Martí, o Roberto Bolaño), hasta las diversas intervenciones de la crítica que lo han resguardado o -lejos de intentar su desaparición- han explorado sus espacios, sus funciones, pareciera que en verdad sí importa quién está hablando (Foucault, 1969).

En Argentina, en los últimos años, han aparecido ensayos críticos que refieren el tema -desde el artículo ya clásico de María Teresa Gramuglio, "La construcción de la imagen", hasta los trabajos que incluyen diversas perspectivas teóricas (como los de Julio Premat o José Amícola) - junto con una vuelta a las "escrituras del yo" que ha suscitado diversas intervenciones críticas por todo el continente. La apuesta de Bolaño a la noción de autor puede examinarse en la construcción de diversas figuras de personajes escritores desde la cuales reflexionar sobre el propio lugar. La canonización de un escritor y la función-autor que le da unidad a su obra al mismo tiempo que la rebasa forman parte del proceso de "invención" que transforma al autor en autoridad “cuya vida ejemplar o significación nacional se considera como más fundamental que sus textos mismos" (Chartier 1998: 22, cursivas nuestras). En Bolaño encontramos una apuesta compleja a la noción de autor, hallamos la presencia de figuras de escritores de diversa índole, de faros literarios no hay duda. Aunque también se pone en jaque de varias maneras como exploraremos en varios textos (sobre todo a partir del concepto de autoficción).

Por otro lado, siguiendo la propuesta de Chartier cuando lee a Foucault, entra en cuestión la noción de pertenencia a una geografía y cultura específicas. Entonces ¿en qué medida Bolaño es un autor chileno? O mejor aún ¿qué significa que Bolaño sea un autor latinoamericano? Así, no solo debemos resignarnos a "la recuperación de una voluntad de lectura totalizadora" (Kohan 2003: 1) que enarbola nuevamente las nociones de autor y obra sino también la de nación, no sólo esta última como narración (Bhabha 1990), también las dos anteriores en tanto relatos, construcciones, derivas. Los textos de Bolaño están atravesados por esa doble pertenencia entre Chile y América Latina que se coloca en el denominado nuevo escenario mundial. 
Si bien nuestra lectura no aspira a "funcionar como totalidad" (Kohan 2003: 2) en tanto clausura pues no pretendemos concluir la aproximación crítica a la narrativa de Bolaño con sentencias reveladoras de sentidos últimos, la interpretación implica en mayor o menor medida un cierre de sentido que asumimos. Pero como no se podrá dejar de leerlo, cada lectura será un fragmento más en el intento por explorar esta “constelación de partes interactivas" (Zaid 2004) que supone su obra narrativa. ${ }^{8}$

Por otra parte, esa sensación de inconclusión que, creemos, forma parte del proyecto literario de Bolaño (y que sólo para asirnos temporariamente a alguna certeza evocamos la categoría de obra abierta y apelamos a la imagen del libro de arena) esquiva todo intento de cierre total de sentido en el juego inteligente que arma y desarma cualquier marco de referencia. En este sentido, como ha sido destacado por más de un crítico, el secreto $^{9}$ aparece como un espacio privilegiado en la escritura de Bolaño, y sin embargo ese lugar constituye un vacío, que posibilita múltiples conjeturas (aquí también Bolaño nos enseña el uso del policial o del fantástico como modos discursivos desestabilizadores), pero ninguna solución, entonces "al rehusar la asignación al texto (y al mundo como texto) de un 'secreto", el texto mismo se pronuncia contra "la detención del sentido" (Barthes 1968). ${ }^{10}$ En nuestra lectura, además, contemplamos este rasgo (lo inconcluso, el secreto, etc.) desde la "escritura del trauma" que recoloca ese vacío en la latencia de un horror del pasado entre el olvido y la memoria.

\footnotetext{
${ }^{8}$ Aquí seguimos la "intervención" de Sandra Contreras -junto a Barthes- cuando le responde a Martín Kohan respecto del Gran Relato que supone una lectura que sostenga al Autor y su Obra en tanto totalidad. Se trata de una interesante discusión en torno a las posibilidades de la crítica, el corpus y la teoría de la que participaron los citados Contreras y Kohan y continuaron Miguel Dalmaroni y Jorge Panesi (Boletín 11 y 12). Señala Contreras: "la explicación, en tanto estabilización y desciframiento, tiene un carácter devaluado (...) esa -ya inútil- pretensión de "descifrar" reduce al texto a un significado último, detiene el sentido, limita su proliferación" (Contreras 2003: 10). Por su parte, el crítico francés afirma: "La escritura es ese lugar neutro, compuesto, oblicuo, al que va a parar nuestro sujeto, el blancoy-negro en donde acaba por perderse toda identidad, comenzando por la propia identidad del cuerpo que escribe." (Barthes 1968)

${ }^{9}$ Ver De Rosso (2002)

${ }^{10}$ Es elocuente el recuerdo de Sergio González Rodríguez (2008): "Roberto Bolaño zen: está acodado en la barra de un bar rodeado de escritores. Dice: si quieres ser novelista tienes que ser capaz de resolver el siguiente enigma: dos hombres roban un banco a punta de pistola, se escapan con el botín y se refugian en una cabaña en la sierra. Al final, la policía localiza la cabaña. El botín está intacto, colocado sobre la mesa. Fuera hay tres tumbas excavadas en la tierra. Dos hombres, tres tumbas. ¿Qué es lo que ha sucedido? Roberto Bolaño invitaba a plantear preguntas precisas (¿murieron los atracadores? ¿Había una mujer?, etcétera). Al final diría, sonriente: "no has podido encontrar la solución del enigma, jamás podrás ser un buen novelista pero, al menos, podrás contar esta historia". Puesto con otras palabras: en el acertijo reside la imposibilidad de narrar por tu parte una historia referida por alguien. Cuando mucho, la convertirás en un relato degradado de lo que oíste. Tal es el trabajo del novelista".

González Rodríguez, Sergio, "Roberto Bolaño zen: fotografía y narrativa indicial", Cátedra Bolaño, 2008, Santiago, UDP, http://www.revistadossier.cl/
} 
Podemos intuir una ambición casi balzaciana (de obra total) en los lazos internos que amalgaman las novelas o relatos entre sí del Hipertexto-Bolaño (ya mencionados, como: personajes que aparecen y desaparecen para volver en otros textos, expansiones de fragmentos que constituyen nuevas obras, mismas situaciones desde nuevos ángulos, o con matices diferentes, etc.). O también es posible pensar que una (im)posible totalidad ha entrado en tal crisis que sólo accedemos a sus astillas, sus fragmentos desperdigados en diferentes textos que se contradicen, se expanden, dialogan entre sí, pero no se completan en un todo coherente. ${ }^{11}$ Otra vez, Barthes: "un texto no está constituido por una fila de palabras, de las que se desprende un único sentido, teológico, en cierto modo (pues sería el mensaje del Autor-Dios), sino por un espacio de múltiples dimensiones en el que se concuerdan y se contrastan diversas escrituras, ninguna de las cuales es la original: el texto es un tejido de citas provenientes de los mil focos de la cultura." Es en esta línea que nos proponemos leer la narrativa de Roberto Bolaño: como un tejido de géneros y voces que interpelan la historia y la literatura. Así, el Hipertexto-Bolaño, el libro de arena, trama un relato imposible de abordar de manera lineal pues su continuidad está atravesada por los quiebres que remiten a la experiencia del trauma. Es el relato de un trauma lo que leemos al tener una visión integral, hipertextual de su narrativa, en el que la memoria y las relaciones entre el mal y la literatura ocupan un lugar central.

La lectura es otro punto clave en la obra de Bolaño. El escritor chileno no escribe la historia reciente latinoamericana, la lee. Porque en Bolaño el Autor es antes que nada Lector. La conclusión que hace Barthes en el ensayo que hemos venido citando constituye uno de los centros vitales y productivos de la escritura bolañana: "el nacimiento del lector se paga con la muerte del Autor”. Esto puede rastrearse a través de las apariciones de personajes autores, como ya mencionamos, y de la presencia de lectores tras la pista del escritor (Césarea Tinajero en Los detectives salvajes, Benno von Archimboldi en 2666) que se dirigen a un fracaso en el que, sin embargo, gana la escritura. En este doble juego que es la literatura, Bolaño resalta el oficio del escritor que es después de leer. Los textos son tanto lecturas de lo real como consecuencia de las

\footnotetext{
11 "Bolaño parece escribir fragmentos de un texto único y desconocido. El juego es: el fragmento que pervierte a la obra, que la desecha como totalidad, pero que también la desea. Llegar al fragmentarismo es llegar al desastre, como territorio de lo que nunca podrá ser totalizado o visto en virtud del conjunto. Trozos sin límite externo, unidos ya no al deseo de la caída sino a la caída puesta en funcionamiento" (Espinosa 2003: 22-23).
} 
lecturas de una función-autor que constantemente deviene función-lector. ${ }^{12}$ Se vuelve entonces necesario destacar la importancia de la biblioteca en Bolaño, sujeto-lector que escribe en consecuencia: su escritura es un efecto de lectura. Cada texto es un estante de la borgeana biblioteca de Babel (otra precursora del hipertexto); por eso, la insistencia en la vida de escritores-lectores, por eso la necesidad de recuperar formas literarias como el policial o el fantástico para leer la realidad latinoamericana.

En resumen, vamos a explorar la narrativa de Bolaño-autor/lector desde América Latina, defendiendo la posibilidad de abordar su "obra" a partir de los debates y agenda de intereses que la teoría y crítica literaria latinoamericana ha manifestado especialmente en el Cono Sur y que se extiende al resto del continente latinoamericano.

Por último, en nuestro ejercicio de "crítica polifónica" (Ludmer 1973) si coincidimos con la lucidez crítica de Wilfrido Corral cuando afirma que estamos ante el "paso absoluto de Bolaño de una literatura latinoamericana estereotipada a una nueva literatura mundial" (2011: 17) también sostenemos que para abrir tal vía de lectura no es necesario sustraerlo de sus raíces -o quizás mejor, sus vísceras: la historia y la literatura recientes latinoamericanas. ${ }^{13}$ En realidad, coincidimos a medias con la cita anterior de Corral y cambiaríamos ese "paso absoluto" por una idea más matizada (y tal vez, menos comprometida) de "bisagra" o "a medio camino" entre los órdenes trazados por Corral, en diálogo con los planteos iniciados con la recepción latinoamericana de Pascale Casanova o Franco Moretti, en las intervenciones de Ignacio Sánchez Prado, entre otros, a la luz del complejo vínculo que Bolaño establece entre Chile, América Latina y "el mundo".

Es preciso colocar a Bolaño en una tradición literaria latinoamericana signada por diversos cambios, desplazamientos que van desde la década de los sesenta, fuertemente marcada por la revolución cubana y las narrativas del boom latinoamericano, hacia el fin de siglo sacudido por las experiencias de las dictaduras y por la emergencia de nuevas escrituras que intentan procesar los significados de esta época "crepuscular".

\footnotetext{
${ }^{12}$ En Bolaño antes que Barthes o Foucault, está Borges: "que otros se jacten de las páginas que han escrito, a mí me enorgullecen las que he leído" ("Elogio de la sombra", 1969), y así lo evoca Bolaño: "soy mucho más feliz leyendo que escribiendo" ("Autorretrato", 2004).

${ }^{13}$ Tal es la idea que comparte Ignacio Echeverría: "El debate sobre la "literatura mundial" adquiere particular acuidad en este punto: el relativo a las simplificaciones, desplazamientos o malentendidos que conlleva una lectura abstraída del marco de referencias en que una obra determinada se explica más cabalmente. Pues no cabe duda de que, aun sin pretenderlo, toda obra ofrece resistencias a su apropiación por parte de un lector desconocedor del marco en que ha sido creada" (2013: 186).
} 
En el marco de la desarticulación de las literaturas nacionales durante la década del noventa, Bolaño constituye un eje renovador al recuperar cuestiones que han formado parte del horizonte de intereses en la cultura latinoamericana. Por un lado, Bolaño escapa al problema de las literaturas del boom signadas por la definición de una identidad latinoamericana que luego fue absorbida por el prisma del exotismo, por parte del mercado literario internacional, a través del realismo mágico o de lo real maravilloso.

De un modo diferente a lo que la crítica literaria latinoamericana plantea respecto de la literatura chicana o niuyoriqueña, entre otras, Bolaño asume que el orden de la biblioteca latinoamericana se descompuso y ya no responde al vínculo entre territorio, lengua y literatura lo que le permite articular por ejemplo, las dictaduras latinoamericanas con el Holocausto y fraguar un mapa latinoamericano (Cono Sur, México, Centroamérica) a través de las múltiples lenguas que reafirman su “extraterritorialidad” (Echeverría 2002, 2007). Los textos de Bolaño no reproducen "el castellano neutro", la lengua aplanada del mercado editorial y de los medios masivos de comunicación sino que desde la mezcla -y no la mímesis- se construye una escritura atenta a las jergas, a los modismos del espacio latinoamericano. No es el mexicano rural de Juan Rulfo, ni el rioplatense de Juan Carlos Onetti, o el guaraní de Augusto Roa Bastos ni el quechua de José María Arguedas. La valorización de lo heterogéneo que la diversidad de las lenguas de Bolaño actualiza supone menos una identificación esencialista y territorial que una apertura de fronteras (por las que cruzan las lenguas, las literaturas y las violencias); y también está lejos de exotizar la multiplicidad permitida por la globalización. Los detectives salvajes es el ejemplo más impresionante (los argentinismos de Fabio Ernesto Logiacomo, el voseo de la uruguaya Auxilio Lacouture, los chilenismos de Andrés Ramírez, las muletillas caribeñas de los nicos, entre otros), pero no es exclusivo. Bolaño puede usar "follar" o "coger", "gilipollas" o "ciútico"; incluso hasta puede imitar el tono de las traducciones hispanas del inglés, como bien nos muestra "La parte de Fate" en $2666 .{ }^{14}$

\footnotetext{
${ }^{14}$ La cuestión de la lengua arrastra varios años de debate latinoamericano y no es un tema que pierda vigencia. En este sentido es interesante la intervención de un grupo de intelectuales (profesores universitarios, escritores, académicos, etc) argentinos que proponen la creación de espacios de estudio y debate sobre el tema y apuestan "a generar un estado de sensibilidad respecto de la lengua, que no se restrinja a una reflexión académica sino que enfatice sobre su dimensión política y cultural, y que se proyecte sobre las grandes batallas contemporáneas alrededor de las hegemonías comunicacionales y la democratización de la palabra" ("Por una soberanía idiomática", Página 12, Buenos Aires, 17 de septiembre, 2013) .
} 
Bolaño si bien desconoce fronteras en el sentido más clásico, de nacionalismos o localismos, apuesta a lo latinoamericano como parte activa y no periférica de la cultura occidental, la imagen no es muy optimista (dictaduras, derrotas etc) pero aun así es. Y por ello, resulta interesante vislumbrar cómo Bolaño recupera de alguna manera la idea de la literatura como documento, sea de civilización o de barbarie, de cuyo legado (atemporal pero no ahistórico) no podemos prescindir y parece coincidir con César Aira cuando escribe:

"Arte es la actividad mediante la cual puede reconstruirse el mundo, cuando el mundo ha desaparecido" (2004:82). 


\section{2. La parte de los críticos}

La argentina Celina Manzoni tempranamente compiló y editó un aporte pionero a la obra del escritor (Roberto Bolaño. La escritura como tauromaquia, 2002), el cual reúne artículos y entrevistas que ya habían sido publicados en distintos medios latinoamericanos junto con lecturas inéditas de obras específicas.

El objetivo de algunos de estos ensayos es el de divulgar la narrativa del escritor chileno, como las reseñas o presentaciones a sus libros publicadas en periódicos y revistas culturales (como El Mercurio de Chile, La Vanguardia de Barcelona, y otros de Argentina, México, Venezuela, España). Es interesante la inclusión de los comentarios de escritores que valoran tempranamente la obra de Bolaño y la reconocen como parte de su propia generación de latinoamericanos (y españoles). A modo de ejemplo, Juan Villoro afirma que Los detectives salvajes es "una de las más brillantes novelas mexicanas" y Enrique Vila-Matas asegura que Bolaño "es el escritor que más se parece a mí, o viceversa".

El volumen también cuenta con análisis críticos sobre algunas de las obras de Bolaño como La pista de hielo, La literatura nazi en América latina, Monsieur Pain, Estrella distante y Los detectives salvajes, novelas que organizan la estructura del volumen junto con los cuentos de Llamadas telefónicas. Si bien son estudios de obras específicas, permiten perfilar líneas de lectura para ingresar en la narrativa bolañana. Cabe destacar la inserción de su obra en una tradición que traspasa las fronteras chilenas, en constante diálogo con el corpus literario latinoamericano y hasta occidental. Al respecto, las lecturas de Celina Manzoni o Ignacio Echeverría de La literatura nazi en América latina develan un linaje argentino, particularmente a partir de Borges, en las relecturas - y reescrituras- de Historia universal de la infamia. Para Juan Masóliver Ródenas, el fragmentarismo y la acumulación que caracterizan a Los detectives salvajes, ubican a esta novela en la tradición que Cervantes inauguró y a la que también pertenecerían Cortázar o Monterroso. Por su parte, Marcelo Cohen integra la lectura de Estrella distante a los modos de armar el relato de la narrativa policial estadounidense, "un escepticismo chandleriano, quizás austeriano, pero histriónicamente, empastadamente universal" (2002: 35).

En cuanto a la relación de Bolaño con la historia de la literatura latinoamericana -y con la historia a secas-, Gonzalo Aguilar bien describe un tono melancólico, contra 
el "entusiasmo" de las narrativas del boom. Para Bolaño "ya no emana ninguna autoridad ni de la literatura, ni de los escritores" (2002: 148), en tanto pertenece a un campo literario signado por la violencia y la barbarie de las últimas dictaduras latinoamericanas.

Las visiones más generales abordan la obra a partir de una serie de características tales como el desplazamiento, la búsqueda, la vaguedad, las alusiones. Recorridos geográficos (Chile, México, Francia, España), identidades borrosas, relatos intercalados, hechos que se anuncian y no suceden, una galería de personajes en tránsito, constituyen otros elementos que conforman un universo en constante movimiento a partir de lo que Elvio Gandolfo denomina "bulimia argumental" (2002: 115-119). Por último, el volumen recopila cierta bibliografía existente, sobre todo en la red y en publicaciones periódicas (diarios, revistas, suplementos culturales, etc.). ${ }^{15}$

El segundo aporte a la bibliografía crítica de Bolaño es Territorios en fuga. Estudios críticos sobre la obra de Roberto Bolaño, proyecto dirigido por Patricia Espinosa (2003), de la Universidad de Chile, con el objetivo de reunir ensayos sobre el escritor y, al mismo tiempo, difundir "la nueva crítica chilena". Con la explícita intención de intervenir en el espacio de la crítica literaria, ${ }^{16}$ se incluyen múltiples voces con predominio de los más jóvenes (junto a José Promis o Grínor Rojo, encontramos las nuevas perspectivas de Magda Sepúlveda, Alvaro Bisama, Cristian Gómez, Roberto Contreras, entre otros). Nuevas miradas que irrumpen en la escena académica de la democracia para llenar un vacío, al igual que Roberto Bolaño "intervino de manera radical en el triste panorama narrativo chileno". En un tono casi polémico, el volumen se presenta más como el intento de instalar un debate en torno a la controvertida figura del escritor y los modos de hacer crítica en Chile que como un nuevo aporte al estudio de la obra de Bolaño.

Todos coinciden en el lugar diferenciado que ocupa el autor en la literatura de Chile. Según Darío Osses, Bolaño instituye "una voz propia” que sacude el polvo de la narrativa chilena más preocupada por vender que por escribir; su figura pública $-\mathrm{y}$ literaria- deja una fuerte impronta "en una órbita distinta a los demás" para Álvaro Bisama. La narrativa de Bolaño se posiciona en el campo literario chileno de los

\footnotetext{
${ }^{15}$ Asimismo, abundan en Internet artículos y reseñas sobre sus obras; tanto en publicaciones electrónicas como en páginas individuales.

${ }^{16}$ La editora, Patricia Espinosa, señala: "Creí necesario recuperar la función crítica, recoger escrituras cuyos tonos, paradigmas, recurrencias, desvíos y contradicciones nos permitan advertir cómo se articula hoy la crítica y desde dónde y cómo se lee a Bolaño".
} 
noventa desde un margen ambiguo, que el mismo autor ha incentivado a partir de una imagen de escritor irreverente, poco adepto a las instancias de legitimación de -algunos de- sus pares chilenos: talleres, entrevistas, cócteles editoriales. Esta imagen se desdibuja, en parte, al confirmarse el lugar central que ocupa en las letras latinoamericanas, no sólo a partir del éxito editorial de sus obras sino de las lecturas realizadas por la academia y la crítica (como lo confirma este volumen de Espinosa), a pesar de que esta centralidad se muestre parcial en Chile, en tanto sólo es reconocida por unos pocos. ${ }^{17}$ No es casual que en los dos textos que ofrecen un panorama de la narrativa chilena actual, como el del crítico Rodrigo Cánovas, Novela chilena: nuevas generaciones. El abordaje de los huérfanos (1997) y la compilación de ponencias leídas en el seminario organizado por el diario La Época sobre "Nueva narrativa chilena" (1997), el nombre de Roberto Bolaño sólo se mencione en esta última publicación, en dos oportunidades.

Si bien la edición de Espinosa incluye ensayos sobre la poesía de Bolaño, el análisis de sus cuentos y novelas ocupa un lugar central en la labor crítica, predominando las lecturas de la novela que lanzó al escritor a la vorágine editorial y le otorgó un lugar fundamental en la literatura latinoamericana: Los detectives salvajes (1998). ${ }^{18}$

A partir de lo que Patricia Espinosa denomina "su condición de latinoamericanidad deslocalizada", el abordaje de su obra se organiza a partir de ciertos tópicos -antes mencionados- como la pertenencia a una tradición latinoamericana (el análisis de Promis, por ejemplo, se retrotrae a las vanguardias); y de conceptos tales como el desplazamiento, las identidades en fuga, la vaguedad, la hibridez, ya sea por sus temas o por el uso de diferentes géneros y subgéneros, particularmente el policial (en los trabajos de Magda Sepúlveda, Roberto Contreras y Marcelo Novoa),

En los últimos años, ha aparecido un sinnúmero de trabajos críticos que abordan la narrativa completa del autor. Dos de ellos, El balido de la oveja negra: La obra de Roberto Bolaño en el marco de la nueva Narrativa Chilena de Patricia Poblete Alday,

\footnotetext{
${ }^{17}$ Al respecto, Espinosa aclara: "Acostumbrados a un campo cultural donde cada persona que tiene una cuota de poder lo ejerce con violencia segmentadora, decidí hacer un gesto obviamente retrógrado. La idea ha sido invitar, incluso a los supuestos 'enemigos' de Bolaño, y exponer sus escrituras a la confrontación. No resulta casual, en todo caso, que un importante número de narradores y críticos se haya negado a participar bajo mil y a veces entendibles excusas. Gestos que sin duda revelan un miopía extrema, pero cuyas causas profundas tienen mucho que ver con el estado actual del quehacer crítico."

${ }^{18}$ Obtuvo el Premio Herralde de novela en 1998 y el Rómulo Gallegos al año siguiente.
} 
(UCM, 2006) y Pistas de un naufragio. Cartografía de Roberto Bolaño de Chiara Bolognese (Alción Editora, 2010), sintetizan algunas de las principales líneas de lectura.

Poblete Alday analiza la obra de Bolaño desde los aportes críticos y teóricos sobre el mito y la postmodernidad. El objetivo de esta tesis doctoral es delinear algunos rasgos significativos de su narrativa marcando similitudes y diferencias con la denominada Nueva Narrativa Chilena. La tesis plantea que los relatos de Roberto Bolaño reactualizan los patrones narrativos de la mitología. La lectura no incluye un análisis pormenorizado del trabajo que Bolaño realiza con otras formas genéricas tradicionales, pero incluye una mención a la literatura fantástica desde una perspectiva ortodoxa (Todorov). Con insistencia se afirma que los textos de Bolaño no son fantásticos y -pese a citar los postulados de Jackson- solo se incluye a lo fantástico en tanto fuente de temas. No se los considera como parte constitutiva de una escritura que utiliza la tradición literaria de manera novedosa, sino como motivos que reflejan la condición posmoderna, con su fragmentarismo y crisis del lenguaje.

Chiara Bolognese también ofrece un recorrido por ciertos temas o ejes de la poética de Roberto Bolaño en el marco de la postmodernidad. A partir de subtítulos que indican temas o rasgos del estilo posmoderno, luego de una breve descripción, se detallan obras a modo de ejemplo, intercalando citas que ilustran lo mencionado. Es un recorrido muy general por algunas características recurrentes en los textos a la luz de algunas nociones centrales de Zygmut Bauman que funcionan como intervenciones teóricas para enmarcar la lectura (espacio líquido, la fluidez), aún cuando esas intervenciones no son necesarias para clarificar la lectura. Ambos estudios, el de Bolognese y el de Poblete Alday, trabajan con la postmodernidad como matriz temática y formal, articulando rasgos ya mencionados por la crítica con referencias a los textos. Un aspecto a destacar en la investigación de Bolognese es la inclusión de la poesía de Bolaño en el análisis, dando cuenta del universo Bolaño de un modo más abarcador.

Otras compilaciones y trabajos se han sumado al aluvión crítico sobre Bolaño (Moreno y Paz Soldán; Ríos Baeza y Candia, por mencionar algunas). Nos interesa destacar dos publicaciones en tanto emergen con la consciencia de propiciar un giro a las lecturas críticas del "primer momento", de fines de los noventa. En este sentido, Raúl Rodríguez Freire (2011) compila un nuevo volumen crítico sobre el escritor de Los detectives salvajes y, reconociendo sólo dos antecesores (los trabajos iniciales de Celina Manzoni y Patricia Espinosa), asevera el cambio de época respecto de la recepción de la obra de Bolaño. Los pioneros trabajos hacen eco de la urgencia de leer y mostrar 
mientras que finalizando la primera década del nuevo siglo el proyecto de Rodríguez Freire se presenta "contra su banalización y el consecuente extravío de su potencia" (9). Contra el lugar común, entonces, que para Rodríguez Freire la crítica moderna instala en las lecturas de Bolaño (abocada al catálogo de la literatura latinoamericana con el boom como horizonte y la temática de la violencia como color local) Fuera de quicio apuesta a explorar la "política radical de su estética" poniendo el eje en la literatura, sin que los adjetivos gentilicios importen. En esta línea, Wilfrido Corral (2010) aborda el lugar que ocupa Bolaño en el marco de la denominada literatura mundial y apunta a cierto sector de la crítica especializada a partir de la recepción anglosajona de Bolaño. En contrapunto con el volumen que Ignacio Sánchez-Prado edita para incluir a América Latina en el debate por la literaria mundial, Corral asume un postura polémica respecto de las "previsibles y dependentistas reacciones "teóricas" latinoamericanistas" al detenerse en las reseñas que la crítica anglosajona ha realizado en base a los cuentos de Bolaño para colocarlo dentro de la nueva literatura mundial e interpelar a nuevos críticos que adviertan la inflexión que las obras de Bolaño sostienen para la crítica en tiempo presente.

Nuestra propuesta, como ya adelantamos, aborda la narrativa del escritor chileno en su conjunto para explorar cómo el Hipertexto-Bolaño se coloca en las problemáticas en torno a los vínculos entre la literatura y la memoria reciente y sus enclaves traumáticos desde América Latina sin que ello implique cerrarle las puertas de la cada vez más mencionada mundialización. 


\section{II. “PASILLO SIN SALIDA APARENTE”: LA MEMORIA EN EL CHILE DE LA POSDICTADURA}

\section{(...) la turbiedad de una memoria que debe seguir perturbando}

Nelly Richard

\section{1. La memoria bajo la dictadura: entre el testimonio y la hipervanguardia}

Considerar el contexto histórico en el cual Roberto Bolaño ha escrito su obra, implica explorar el escenario de los debates en torno a las herencias de las últimas dictaduras latinoamericanas, e indagar las reflexiones sobre la memoria, asumiendo la singularidad del caso chileno.

Para comenzar, realizaremos una aproximación al campo intelectual chileno a la luz de las intervenciones teórico-críticas -en especial aquellas promovidas desde la Revista de crítica cultural, dirigida por Nelly Richard- vinculadas con las problemáticas de la memoria, tales como el trauma, el duelo, la culpa, la violencia, el terrorismo de Estado, los sistemas dictatoriales, la revisión del pasado, entre otras. Con la apertura democrática, la cuestión de la memoria ha sido un tema fundamental y, desde múltiples voces la "memoria" se coloca en un espacio fracturado de revisión y elaboración del pasado reciente. El lenguaje narra la condición posdictatorial en términos de trauma, duelo, melancolía (Alberto Moreiras, Tomás Moulián, Pablo Oyarzún, entre otros), y a través de estéticas que proclaman la pluralidad de sentidos, contra el olvido, el consenso, la reconciliación y la impunidad (Nelly Richard, Diamela Eltit, Sergio Rojas, Willy Thayer, entre otros).

Asimismo, la reflexión en torno al pasado traumático conlleva el análisis de los posibles modos de relatar y procesar la experiencia de las dictaduras y sus significaciones en el presente: el "cómo narrar". Por lo tanto, definir la propuesta estética de Bolaño (en especial el modo en que articula desde su narrativa el problema de la memoria) implica tomar en cuenta el campo literario chileno de los noventa, atravesado por la tensión entre una línea testimonial, la hipervanguardia y las nuevas 
narrativas (neorrealismos, neobarrocos, neoliberales). Es, en el cruce de estas corrientes literarias, donde Bolaño articula un realismo particular, el "realismo visceral"; posicionándose en el campo literario latinoamericano, en diálogo con los debates actuales en el marco de los denominados nuevos realismos, o "realismos adjetivados" (De Diego 2001) que desarrollaremos más adelante.

Si bien la obra de Bolaño se publica ya iniciada la democracia, resulta necesario retrotraernos al momento de la dictadura a fin de evaluar allí ciertos modos en que la literatura va definiendo perspectivas y propuestas frente a la experiencia dictatorial. En este sentido, Nelly Richard describe la configuración de espacios enunciativos en el campo literario e intelectual bajo el gobierno de Augusto Pinochet, y confronta dentro del "polo victimado" - que de ningún modo resulta uniforme ni coordinado-dos escenas culturales como alternativas a las crisis provocadas por la dictadura, dos campos discursivos que interpelan al régimen militar (Richard 1994: 55).

Por un lado, las estéticas del testimonio, las épicas de la resistencia que, para Richard, "siguen subordinadas al contenido programático de referentes totales y hegemonizadores de sentido" (1989:17) y, por el otro, las estéticas de la ruptura, las poéticas del desajuste, el deshecho, la fragmentarización y la reconstrucción que caracterizan a gran parte de las producciones de las artes plásticas, la fotografía y la literatura.

Los dos polos antes mencionados se continúan en la apertura democrática dando lugar al discurso sociológico, por un lado; y al anti-proyecto de "crítica cultural" de Nelly Richard, surgido en torno a las prácticas culturales de la hipervanguardia o escena de avanzada, ${ }^{19}$ por el otro. El primero utiliza la perspectiva de la sociología y se preocupa por la elaboración de marcos teóricos para pensar -en la transición- la reforma del estado, el perfil de la democracia, los resabios del autoritarismo, los problemas de la modernización y del neoliberalismo, entre otros. Sus representantes más destacados son José Joaquín Brunner, Norbert Lechner, Martín Hopenhayn y Tomás Moulian. Mientras que el otro polo emplea la lengua literaria y las herramientas del arte para ocuparse de otras problemáticas de la sociedad postdictatorial menos procesadas, como lo residual y contradictorio, lo traumático e intempestivo del recuerdo y de la violencia. Ambas posiciones implican diversas -casi opuestas- políticas de

\footnotetext{
${ }^{19}$ Movimiento artístico formado a finales de los setenta y principios de los ochenta del que participaron artistas plásticos, escritores que, con palabras de Nelly Richard, intentan una "salida de marco" contra la dicotomía orden/caos de la dictadura para liberar alternativas de sentido a través de lo estético.
} 
intervención en la esfera pública: mientras desde la sociología se intenta tender puentes con la recientemente inaugurada transición; en cambio la Revista de Crítica Cultural y el grupo de artistas de la avanzada radicalizan su crítica. Teresa Basile resume las dos posturas en la transición chilena: "mientras FLACSO buscó los modos de reconducir el proceso democrático a través del 'consenso' y la 'negociación' de las partes escindidas del cuerpo social e incluso la participación activa de algunos de sus miembros (...) Richard se opone a esas alianzas de poder y elige una suerte de margen extremo y siempre desarticulante" (1997: 30). Un margen que opera en términos de resistencia.

También ambas posiciones disponen vías alternativas para la memoria. Nelly Richard valoriza los modos en que el arte y la literatura procesan el pasado reciente, evitando cualquier tipo de cristalización o fijeza. Por otro lado, acusa a la cultura de izquierda, (acercando la izquierda partidaria y militante a la izquierda renovada) de revalidar el Chile anterior al Golpe de 1973 en un proyecto de restitución de la memoria y a partir de la prédica de una continuidad de los valores fracturados por la experiencia de la dictadura. Sin embargo, los intelectuales de FLACSO -en abierta polémica con Nelly Richard- prefieren y defienden una memoria que tenga capacidad de institucionalizarse, y que permita en su nombre articular políticas de diversa índole en el marco de los reclamos por los Derechos Humanos. Así, la cuestión de la "memoria" surge en un espacio fracturado de revisión y elaboración del pasado, que incluye desde un lenguaje que narra la condición posdictatorial en términos de trauma, duelo, melancolía, hasta las "discursividades en fuga" que, sostenidas por el disenso, desterritorializan el lenguaje y experimentan con el sentido.

Es necesario destacar que este mapeo del contexto chileno de la posdictadura es funcional al proyecto de Nelly Richard, quien contrasta dos posiciones estéticas -y políticas-, dejando de lado otras intervenciones que también constituyen el campo cultural chileno, para así posicionarse como uno de los polos en cuestión, aquel que ejerce la crítica retrospectiva de la dictadura, frente a quienes prefieren la negociación. Para la ensayista chilena, el discurso de las ciencias sociales carece del registro problematizador de la lengua poética, de la matriz desestabilizadora del arte, necesaria para cuestionar la trama social y cultural que dejó la dictadura. La palabra violentada necesita reencontrar nuevos sentidos y busca intervenir desde un margen, para no ser incorporada al aparato estatal del consenso: "Las palabras resignificándose a sí mismas en polémicas verbales con los léxicos de la academia o de la institución, son parte del trabajo crítico-cultural que consiste en echar el signo a pelear contra el reparto oficial de 
las categorizaciones acreditadas" (1992: 5). Así, en una incisiva entrevista hecha por la Revista de Critica Cultural a José Joaquín Brunner, ${ }^{20}$ despunta la crítica a los "referentes plenos", a la "linealidad y transparencia" socio-comunicativa, atribuidos a las ciencias sociales, caracterizadas como reticentes a nuevas búsquedas discursivas. A su vez, Brunner, desde la sociología, cuestiona “el elogio de los márgenes”, apuntando con ello a la posición de Richard, como inoperante y defiende la necesidad de lo institucional $-\mathrm{y}$ del mercado- porque, indefectiblemente, el objetivo es intervenir políticamente en el espacio público.

Al ubicarse como interlocutora en un espacio bipolar, aun desde una defensa del margen, Nelly Richard buscará un acceso a la centralidad, apelando al arte y a la literatura como prácticas del disenso en medio de los pactos conciliatorios post Pinochet. Nos interesan las intervenciones de este proyecto en tanto interrogan acerca de una "poética de la memoria": qué posibilidades discursivas iluminan un pasado traumático en el presente conflictivo; de qué manera es posible dar cuenta de ello y qué papel le cabe, entonces, a la literatura en esta coyuntura. Estos interrogantes se continúan en un escenario particular: la Concertación.

${ }^{20}$ En el primer número de la Revista de Crítica Cultural, mayo de 1990. 


\section{2. La memoria en la democracia 'pactada'}

El fin de la dictadura en Chile presenta particularidades dentro de los procesos democratizantes experimentados en el Cono Sur, en el marco de las denominadas "transiciones conservadoras" (Ansaldi 2010) sujetas a condiciones según los acuerdos que en mayor o menor medida se establecen entre las cúpulas militares y las civiles o partidarias, como señala Waldo Ansaldi para el caso chileno. A fines de la década del 80, comienza la denominada "democracia pactada" o "democracia limitada" a partir del Plebiscito Presidencial de 1988 que decidirá el destino de Augusto Pinochet. El objetivo fue conseguir el apoyo popular que convertiría a Pinochet en el primer presidente civil. La Junta Militar accede a la posibilidad de un régimen democrático en el que se mantiene el marco político y legal -que le es favorable- de la Constitución de $1980^{21}$, avalada por los partidos políticos de la transición. El resultado del Plebiscito fue de $44,01 \%$ por el "Sí" y 55,99\% por el "No". ${ }^{22}$ La victoria de la "Concertación de Partidos por el No" no significó, sin embargo, la derrota de Pinochet. Su continuidad en la escena política (Senador vitalicio y Comandante en Jefe del Ejército) debilita la idea de un Chile en democracia plena. ${ }^{23}$

La "transición" estimula una revisión crítica del pasado, tarea que oficialmente en Chile se reduce a los llamados "pactos para la reconciliación". De hecho, el presidente Patricio Ailwyn establece, en 1991, la Comisión Nacional de Verdad y Reconciliación, la cual publica el documento conocido como Informe Rettig. ${ }^{24}$ En este texto se esquiva la revisión del pasado traumático, en pos de un presente sin conflictos

\footnotetext{
${ }^{21}$ Entre las enmiendas efectuadas, se destaca la que establece la misma cantidad de miembros civiles y militares en el senado, lo que permitirá la vigencia del gobierno dictatorial en el proceso democrático. Carlos Ruiz explica: "La Constitución del 80 (...) establece límites al sufragio universal como fuente de las autoridades democráticas y concede un rol político de primera importancia a las Fuerzas Armadas." En: "Democracia, consenso y memoria: una reflexión sobre la experiencia chilena". Politicas y estéticas de la memoria, Nelly Richard (comp.), Santiago, Cuarto propio, 2000.

${ }^{22}$ En las elecciones, realizadas al año siguiente, asume el demócrata cristiano Patricio Aylwin. Ver Garretón M., Manuel Antonio, El plebiscito de 1988 y la transición a la democracia., Santiago de Chile, FLACSO, 1988.

${ }^{23}$ Felipe Portales en una entrevista declara: "Después de la dictadura se establece un régimen derivado de la propia dictadura, que es la democracia tutelada o nominal. Démosle el nombre que queramos, pero en el fondo no es un régimen democrático que cumpla con los requisitos mínimos que para tal efecto ha definido la humanidad. En Chile la Constitución y las leyes no son el producto de la voluntad popular. Además la dictadura dejó amarrado un conjunto de leyes que en virtud del sistema electoral, que ella misma impuso, se hacen prácticamente imposibles de ser modificadas". La Nación on line Chile (www.lanacion.cl "El mito de la democracia en Chile", domingo 29 de agosto de 2004

${ }^{24}$ El presidente de la Comisión fue el entonces senador Raúl Rettig Guissen
} 
para un futuro prometedor: "La Comisión Nacional de Verdad y Reconciliación cuyo objeto ha sido contribuir al esclarecimiento global de la verdad sobre las más graves violaciones a los derechos humanos cometidas en los últimos años, con el fin de colaborar a la reconciliación de todos los chilenos". ${ }^{25}$ El informe analiza el contexto del golpe militar en términos de una bipolaridad extrema, un enfrentamiento político que instaló un estado de crisis en la sociedad chilena. Esta polarización facilita, en la transición democrática, la coexistencia pacífica entre el gobierno y las Fuerzas Armadas. Carlos Ruiz (2000: 18) analiza lo que él denomina el "estilo elitista, tecnocrático y consensual de la democracia en la transición" a partir de la Comisión Rettig y resalta "el hecho que se incluya en la definición de las violaciones a los derechos humanos también a actos terroristas" como "sintomático de este espíritu ecléctico y consensual que equipara lo que fueron crímenes perpetrados desde el estado militar con actos de resistencia frente a un poder dictatorial".

Al equiparar la culpabilidad entre actos terroristas y crímenes dictatoriales se aplana todo conflicto inherente a la elaboración de un pasado doloroso. Y también la memoria de la reconciliación evade toda responsabilidad, a través de una simbólica aceptación de las violaciones contra los derechos humanos durante el gobierno militar. La sociedad chilena se conforma, entonces, con admitir que estos hechos ocurrieron; el marco legal y político del país impide la realización de juicios. ${ }^{26}$ Es interesante comparar con el caso argentino: el primer gobierno democrático postdictatorial posibilita la creación de la CONADEP, el informe conocido como Nunca Más y el posterior juicio a las Juntas Militares. En la llamada teoría de los dos demonios se homologa la violencia polarizada de las Fuerzas Armadas y la guerrilla, entre las cuales la sociedad se asume como víctima inocente de un enfrentamiento que no buscó y del que no participó. Este relato anclado en la memoria del Nunca Más oficializó el pasado dictatorial a la luz de la lucha de los organismos de derechos humanos y las posibilidades jurídicas de procurar justicia ante lo sucedido. ${ }^{27}$

En cambio, la sociedad chilena se conforma con admitir que estos hechos ocurrieron y el marco legal y político del país impide la realización de juicios. Memoria

\footnotetext{
${ }^{25}$ Informe Rettig en "Puro Chile. La memoria del pueblo": http://www.purochile.org/rettig00.htm. Cursivas nuestras.

${ }^{26}$ Ver también en el mismo volumen: Moulian, Tomás "La liturgia de la reconciliación". Es interesante comparar con el caso argentino: el primer gobierno democrático postdictatorial posibilita la creación de la Conadep, el informe conocido como Nunca Más y el posterior juicio a las Juntas Militares.

${ }^{27}$ Como ejemplifica Florencia Levín (2007) "(la fiscalía) durante el Juicio a las Juntas, que eligió no mencionar la participación política de las víctimas para reforzar el argumento de la violación, por parte de los militares, de los derechos humanos universales".
} 
y justicia sólo conviven en el plano simbólico, lo que requiere un estado de alerta frente a las políticas de la memoria. 


\section{3. Intervención en la memoria pactada: la Revista de crítica cultural}

En este contexto inicial de la democracia "limitada" o "pactada" nace la Revista de Crítica Cultural (primer número en mayo de 1990), bajo la dirección de Nelly Richard, como un fuerte gesto de intervenir en las discusiones enmarcadas en la apertura democrática: memoria, mercado, consenso, etc. Así, el primer número publica una serie de artículos bajo el título "Transición, cultura, democracia" con textos de Beatriz Sarlo, Hugo Achugar, José Joaquín Brunner y Julio Ortega, como los primeros voceros de un proyecto que se posiciona en la agenda de debates de Chile y de América Latina. A partir de una poética que defiende lo transgresivo, lo disruptivo, la revista pretende ocupar un lugar en las reconfiguraciones del campo cultural chileno.

La memoria es una de las cuestiones principales abordadas por esta revista y se coloca como eje inevitable de discusión ante la pasividad de las políticas estatales. Se impone la necesidad de reflexionar en torno al "cómo nombrar" el pasado reciente. Así, surgen expresiones como "abrir fuego", con frases de Guadalupe Santa Cruz, o "irrumpir en esa costra mediante la palabra que nombra y delira" (1995: 17) para describir la tarea crítica de discutir la memoria en medio de los pactos del consenso. Se exige una "memoria activa, no como mero depósito de hechos del pasado, sino como conglomerado de "residuos de significación histórica y narrativas en curso que busca ser ella misma intervención, suceso y realidad" (Richard 1995: 33), no sólo contra el silencio oficial, sino además contra la versión nostálgica de cierta discursividad de izquierda que intenta suturar el quiebre dictatorial volviendo a un idílico 'estado anterior'. Se trata, entonces, de hacerse cargo del presente en su condición postdictatorial. La "posdictadura" le recuerda al presente que es "producto de una catástrofe pasada" (Avelar 1997: 22). Idelber Avelar rechaza las denominaciones que "no apunten su procedencia y así su burda actualidad, su mera presencia: tiempos de 'democracia, (...) 'estabilidad', (...) 'gobernabilidad" a favor de una "mirada que aspira a ver en el presente lo que a ese presente excede -el suplemento que el presente ha optado por silenciar (...) su condición postdictatorial, su fantasmagórico duelo irresuelto" (2000: 37). Alberto Moreiras también reflexiona sobre las características y tendencias del pensamiento en la postdicadura: la derrota, el duelo, la melancolía y la 
posibilidad de sobreponerse a la pérdida del horizonte utópico a través de un pensamiento crítico.

La crítica al mercado es fundamental en el Chile modernizado de la posdictadura. Dinámico y veloz, el mercado trasmite una memoria "liviana" que refiere el pasado evitando toda reflexión sobre el mismo, y resulta orgánico al proyecto tranquilizador de un recuerdo bajo el signo de la reconciliación. El "boom de la memoria" (Huyssen 1999:8) forma parte de la industria de la memoria en un escenario caracterizado por la "simulación", que negocia por medio del trueque: estabilidad por silencio (Moulián 1996: 5).

Un momento crucial del debate fue lo que la revista denominó "El estallido 'Pinochet", ${ }^{\prime 28}$, es decir, la detención del dictador en Londres, los 503 días que para los chilenos amenazaron la impunidad en Chile. Este acontecimiento reactivó la necesidad de revisitar el pasado, desgarrando "el velo transparencial del hipotético consenso" (Villalobos-Ruminott 1999: 20). Cabe destacar que, tal como indica Waldo Ansaldi, a partir del 2000 se advierten una serie de eventos como "pasos significativos" para dejar atrás los "condicionantes institucionales impuestos por el pinochetismo" (Ansaldi 2010) -desde el desafuero de Pinochet en 2000 hasta las enmiendas de la Constitución de 1980 en 2005.

Se reabre el debate pero, rápidamente, es digerido por la dinámica de la sobreabundancia, transformándose en "una sobredosis de indigestión historizante" (Jocely-Holt 1999: 30). Como lo resume Willy Thayer, la memoria de la concertación pasó de la documentalidad a la publicidad, para que lo acontecido circule como recuerdo y documento colaborando así “con la conversión del 11 de septiembre de 1973 en caso finiquitado" (2004: 13)

Nuevamente la revista se posiciona como vigía contra toda tendencia de osificación y construcción de imágenes maniqueas, estancas de la memoria “oficial”. Miguel Dalmaroni analiza cómo, en intervenciones hechas por la escritora Diamela Eltit y, sobre todo, por Nelly Richard, la Revista de Crítica Cultural participa en los debates posdictatoriales sobre la construcción de una memoria y, por ende, sobre los modos de narrar el pasado traumático, privilegiando una poética del nomadismo, la fuga, la incertidumbre (Dalmaroni 2004: 132), exacerbando la práctica de la fragmentación y el quiebre. Sin embargo, Dalmaroni advierte también la recuperación de un sentido

${ }^{28}$ Ver Dossier homónimo en la Revista de Crítica Cultural, no 18, junio 1999. 
reconocible, hasta "compartido con la discursividad de la estética testimonial de los movimientos de defensa de los derechos humanos" que se instala en ese discurso que proclama la opacidad. Una poética contra la univocidad del signo que, sin embargo, cristaliza en una ética esperable, por "el reconocimiento de la necesidad histórica y política de ciertos niveles de construcción de 'verdad', de 'restitución' o de 'identidad"'. Hay una oscilación entre la fuga discursiva como forma de resistencia crítica, y la necesidad de fijar "posiciones, enunciados, identidades" (Dalmaroni 2004: 139-141).

Se evidencia, entonces, cómo la revista desarrolla un discurso propio que la diferencia y la ubica en las reconfiguraciones del campo cultural chileno y que, a su vez, le permite acceder a formas institucionalizadas del debate público, también, para establecer un diálogo académico internacional.

En este sentido, el libro del crítico brasileño Idelber Avelar (Alegorías de la derrota: La ficción postdictatorial y el trabajo del duelo, 2000) resulta imprescindible para esbozar un panorama de la escena chilena posdictatorial, pues intenta articular las preocupaciones y propuestas de la Revista de Crítica Cultural con una crítica literaria del Cono Sur. ${ }^{29}$

En la contratapa del libro de Avelar, Nelly Richard describe "una poética de la escritura que hace contrastar la opacidad de sus pliegues y dobleces figurativos, de sus torceduras de pensamiento, con las simplificaciones técnicas e instrumentales del mercado capitalista”. Avelar comparte con el proyecto de la crítica cultural, por ejemplo, el cuestionamiento al discurso de las ciencias sociales, en consonancia con la "hegemonía conservadora en las llamadas transiciones democráticas". ${ }^{30} \mathrm{Si}$ bien el análisis de Avelar aborda la obra de escritores tan disímiles como el argentino Ricardo Piglia, la chilena Diamela Eltit y el brasileño João Gilberto Noll, el marco que describe aporta aproximaciones críticas que exceden tanto las novelas analizadas como las poéticas y teorizaciones promulgadas por la revista en torno a la "memoria en tiempos de mercado".

Así, es interesante el punto de partida y eje de las lecturas de Avelar: lo que denomina el "terreno afectivo de la posdictadura", la experiencia de la derrota, el carácter interminable del duelo y la melancolía. Un marco teórico-crítico a partir del

\footnotetext{
${ }^{29}$ Es interesante notar el recorte que realiza el crítico brasileño, para quien "Cono Sur" refiere Argentina, Brasil y Chile, sin mencionar Uruguay. Basándose en la común experiencia de los procesos dictatoriales, y posdictatoriales, Avelar obliga a repensar la cartografía que demarca el área del Sur, como lo hiciera Jorge Schwarz al incluir a Brasil cuando leyó las vanguardias latinoamericanas.

${ }^{30}$ Avelar analiza los textos de J.J. Brunner, caracterizando su discurso como dicotómico, maniqueo. (p. 77-88)
} 
cual puede leerse la literatura latinoamericana después del boom desde el Cono Sur; una propuesta que permite iluminar las reconfiguraciones gestadas en el campo literario latinoamericano del post-boom y la posdictadura desde el contexto chileno. Las novelas de Bolaño se anclan en este territorio "afectivo" de la posdictadura chilena hurgando en el duelo y la melancolía, pero también extienden la experiencia del trauma a la geografía más amplia de América Latina para perseguir allí las huellas de la derrota de los ideales sesentistas. No obstante, es desde el interior de la democracia chilena "limitada", es desde la memoria "pactada", que Roberto Bolaño aborda con irreverencia ciertos nudos incómodos de la memoria, pero sin colocarse ni en la transparencia de la memoria testimonial, ni en la opacidad de la memoria nómada de la hipervanguardia. Como luego veremos, recupera algunas características del realismo para desplazarlo hacia lo que él llamó "realismo visceral" (versión literaria del movimiento que fundó en México en los setenta, el infrarrealismo). Esta elección estética nos exige explorar el campo intelectual y literario chileno de los noventa, atravesado por diversas propuestas de las que Bolaño toma distancia, y estudiar así sus afinidades tácitas y sus rechazos explícitos respecto de sus pares. 


\section{4. "La herencia de Donoso es un cuarto oscuro", literatura en el Chile posdictatorial.}

Como se señaló anteriormente, la escena chilena de la dictadura -y luego de la democracia- presenta dos extremos constituidos por las estéticas de la resistencia, por un lado, y la hipervanguardia o la "avanzada", por el otro. Esta última reúne escritores y artistas plásticos que, contrarios al pathos de la expresividad testimonial y denunciante, ejercen una crítica al sentido totalizador de la dictadura desde una "estética de los márgenes", lo fragmentario, lo discontinuo. Algunos ejemplos son las obras de Diamela Eltit (Lumpérica, 1983; El padre mío, 1989; Vaca sagrada, 1991; entre otras), y las producciones del Colectivo Acciones de Arte (CADA) a partir de 1975.

En este contexto, Roberto Bolaño no está ni en un extremo ni en el otro, ni proclama una épica de la resistencia ni se refugia en el "fragmentario nomadismo del sentido". Evita los significados totalizadores, escamotea una escritura demasiado anclada en lo político-ideológico, y elige tributar a la generación de militantes de izquierda con un relato que es un homenaje-deuda, escrito desde un distanciamiento problematizador permeado por la melancolía y el humor críticos. ${ }^{31}$

También, a mediados de los ochenta, la transición democrática abrió espacios a nuevas voces que la crítica literaria chilena ha leído en términos generacionales. La llamada "Nueva narrativa chilena" agrupa heterogéneos proyectos estéticos que comparten la experiencia dictatorial en diferentes grados y se posicionan en el espacio del 'consenso', signado tanto por la impronta de las políticas neoliberales como por la construcción de una memoria. La "Nueva narrativa chilena" reúne tendencias disímiles, tales como: la "novela de la orfandad" (Cánovas 1997) -Carlos Franz, Ramón Diaz Eterovic, Gonzalo Contreras, etc. -, el "McOndismo" -Alberto Fuguet y Sergio Gómez (1996)-, las "neobarrocas crónicas" de Pedro Lemebel (Bianchi 1997). Estos cruces dan cuenta de un campo literario franqueado por una diversidad de voces donde resuena la pregunta que se hizo Alberto Fuguet: “¿Qué pasa con Bolaño, el mejor de todos?”.

\footnotetext{
${ }^{31}$ Palabras de Bolaño al recibir el premio Rómulo Gallegos: “(...) todo lo que he escrito es una carta de amor o de despedida a mi propia generación, los que nacimos en la década del cincuenta y los que escogimos en un momento dado el ejercicio de la milicia (....), la militancia, y entregamos lo poco que teníamos, lo mucho que teníamos, que era nuestra juventud, a una causa que creíamos la más generosa de la causas del mundo y que en cierta forma lo era, pero que en realidad no lo era", en "Discurso de Caracas (Venezuela)", 1999 (Bolaño 2004).
} 
Estos narradores y narradoras comparten iguales condiciones de enunciación: la coyuntura histórica del setenta y tres, aunque luego siguen rumbos diferentes. Para Carlos Franz, una vez devaluado el mito de país a partir del vaciamiento de voces autorizadas y de la ausencia de paradigmas ideológicos, "no sólo por la abrupta y total devaluación de la vía chilena al socialismo, sino por [la] entrada de sopetón al siglo de los asesinatos y la violencia", se abren dos corrientes narrativas: una, apela a la denuncia directa; otra, mantiene su "compromiso con el arte, aludiendo a la realidad sin proponérselo". Narrativas que, desde una variedad de estilos y géneros, se caracterizan por un "adiós a las megalomanías socialistas, la llegada de la pequeña historia personal" (Franz 1997: 107-113).

La participación en talleres literarios es otra marca que une a la mayoría de estos escritores, así como su vinculación con el mundo editorial, por haber participado en numerosos concursos que los dieron a conocer, particularmente aquellos de la editorial Planeta (Fuguet 1997:119-122).

Por otro lado, el crítico Rodrigo Cánovas caracteriza a la generación emergente como huérfana, siempre a partir del vacío dejado por 1973. Este grupo comparte "el resentimiento contra la voz del padre" y narra la derrota, y la utopía derrumbada. Cánovas realiza algunas apreciaciones críticas a partir de la temática de las novelas y las clasifica por géneros o "campos imaginarios” (Franz 1997): el policial negro, la parodia y los textos vanguardistas. Se reiteran los nombres de Alberto Fuguet, Gonzalo Contreras, Ramón Díaz Eterovic y Diamela Eltit como representativos de la generación abordada.

A su vez, Soledad Bianchi cuestiona la etiqueta "Nueva Narrativa" a partir de las ausencias. El "mini boom" de la narrativa chilena -coinciden en señalar Cánovas y Bianchi- no es más que un mero fenómeno publicitario, patrocinado por las editoriales más exitistas "de la ya instalada sociedad de consumo a ultranza y de las políticas de libre mercado" (Cánovas 1997: 21-28). También coinciden en la falta de una crítica literaria seria que se coloque más allá de polémicas penosas y denuncian un aparato crítico incapaz de profundizar en poéticas, sólo preocupado por 'datos' de premios y ventas.

El grupo "McOndista" se recorta en el interior de la "Nueva narrativa chilena", se individualiza por sus vínculos con la sociedad neoliberal, por su éxito en el mercado editorial y por su acercamiento a los íconos de la industria cultural. Dos textos paradigmáticos son el de Jaime Collyer (1992), Casus Belli: todo el poder para 
nosotros ${ }^{32}$, y el prólogo a McOndo de Alberto Fuguet y Sergio Gómez (1996). A modo de manifiesto, ambos comparten un tono polémico, irónico e irreverente para irrumpir en el campo literario chileno con el mandato de lo nuevo, contra todo localismo y contra la tradición anterior de boom. ${ }^{33}$ En el prólogo "Presentación del país McOndo", Alberto Fuguet y Sergio Gómez disipan el problema de la filiación literaria a través de la burla irónica contra el realismo mágico y contra toda visión reduccionista de América Latina, que se ancle demasiado en "lo indígena, lo folklórico, lo izquierdista". Prefieren contemplarlo como un continente abierto al neoliberalismo globalizante, y desde un discurso volátil y adolescente, simplifican los procesos históricos, políticos y culturales. $^{34}$

Amparadas por el mercado de las grandes casas editoriales ${ }^{35}$ (las ventas del libro de cuentos Sobredosis (1989) de Alberto Fuguet dieron puntapié inicial al 'mini boom' de la nueva narrativa), estas intervenciones corren el riesgo, según algunos, de participar de una banalización de la literatura y del proceso histórico que ocurre en el complejo contexto cultural de la posdictadura.

Roberto Bolaño parece no encajar en este sector del mini boom de la "Nueva narrativa chilena", incluso, para muchos, resulta un escritor casi invisible. En 1997, el seminario organizado por el diario La Época, "Nueva narrativa chilena", intenta un estado de la cuestión de la literatura chilena posterior a Pinochet, en donde participan escritores, críticos y profesores universitarios. De veintisiete participantes, sólo dos mencionan el nombre de Bolaño (uno de ellos en la pregunta anteriormente citada; el otro, Antonio Avaria, profesor y crítico de El Mercurio). En cierta medida, el lugar de Bolaño no termina de acomodarse en los grupos chilenos más visibles, él mismo trama

\footnotetext{
32 Publicado en Revista Apsi 415, febrero-marzo 1992.

${ }^{33}$ Collyer (1992): “Se acabaron las contemplaciones: no más tacitas de té en compañía de los viejos maestros, no más talleres literarios a su gusto y medida -ahora los maestros somos nosotros-, no más sonrisas y halagos a los patriarcas del 50 o la generación 'novísima' (...) Somos cosmopolitas y universales, internacionalistas, hasta la médula: nuestros camaradas de Buenos Aires, Berlín, Oregón o Barcelona promueven nuestros textos y nosotros los suyos. (...) El boom de la literatura hispanoamericana ha muerto, ¡qué viva el boom!"

34 "McOndo es MTV latina, pero en papel y letras de molde".

"Y seguimos: Latinoamérica es Televisa, es Miami, son las repúblicas bananeras y Borges y el Comandante Marcos y CNN en español y el Nafta y Mercosur y la deuda externa. Vender un continente rural cuando, la verdad de las cosas, es urbano (más allá que sus sobrepobladas ciudades son un caos y no funcionen) nos parece aberrante, cómodo e inmoral. (...) Si hace unos años la disyuntiva del escritor joven estaba entre tomar el lápiz o la carabina, ahora parece que lo más angustiante para escribir es elegir entre Windows 95 o Macintosh.”

${ }^{35}$ Planeta, Grijalbo-Mondadori, Anagrama, Seix Barral frente a editoriales de alcance nacional que editan autores 'alternativos' como LOM, Cuarto Propio, Red Internacional del Libro o Dolmen.
} 
genealogías, parentescos y alianzas que lo desplazan del campo literario nacional, tal como lo expresa en varias entrevistas, ensayos, intervenciones y hasta cuentos.

En 2004, la editorial Anagrama recopila parte de ese conjunto de ensayos de Bolaño, bajo el título Entre paréntesis. Allí se reúnen artículos, columnas, discursos y prólogos -publicados entre 1998 y 2003 en diferentes medios- que abordan la dimensión reflexiva sobre los avatares del escritor, la sustancia de la literatura y los temas luego ficcionalizados en sus cuentos y novelas, así como sus "lugares en la literatura" y sus "lugares en la sociedad" (Gramuglio 1992: 37-64), cuestiones que retomaremos unas páginas más adelante al abordar precisamente las imágenes de escritor desde la óptica de la autoficción y las escrituras del yo.

Bolaño se refiere a Chile como el "país-pasillo" del que melancólicamente reniega -en la acepción religiosa del verbo- en tanto se reconoce chileno, pero prefiere la 'conversión': “Mi única nacionalidad es la chilena lo que no es ningún obstáculo para que me sienta profundamente español y latinoamericano" (20).

Cuando vuelve, luego de veinticinco años de exilio -sobre todo en México y España-, narra ese regreso rescatando sólo dos a figuras: Pedro Lemebel y Nicanor Parra, íconos de la rebeldía, la humildad y la valentía en literatura. Chile es el 11 de septiembre de 1973, es la memoria del fracaso y destrucción de una generación (“¿se puede tener nostalgia por la tierra en donde uno estuvo a punto de morir?", 43), es un país de rostros quietos y silenciosos que miran el suelo, es una literatura exitista consagrada por los premios y las ventas ("En Chile todo el mundo escribe", 68; "La literatura chilena, tan prestigiosa en Chile, no tiene más que cinco nombres válidos, eso hay que recordarlo como ejercicio crítico y autocrítico", 104). Si Bolaño habla bien de literatura lo hace especialmente sobre poesía (Rodrigo Lira, Enrique Lihn, Jorge Teiller, Nicanor Parra, y a Pedro Lemebel, "el mejor poeta de mi generación aunque no escriba poesía", y "cierto" Neruda cuando no es lamentable o repetitivo). Excepto algunos escritores y escritoras jóvenes (como Roberto Brodsky, Gonzalo Contreras, Lina Meruane, Alejandra Costamagna), sentencia que no hay novelistas; hubo Un Donoso y hay donositos a quienes aconseja leer en vez de escribir.

Siempre que haya oportunidad, Bolaño se encargará de diferenciarse de sus pares/padres chilenos; reconoce algunos escritores, especialmente poetas como ya adelantamos (Parra, Lihn) o 'marginales' (Lemebel). Pero deliberadamente, a la tradición chilena opone el poder y la riqueza de la literatura argentina, en la que traza linajes y tradiciones a partir de Jorge Luis Borges (y también Macedonio Fernández, 
Julio Cortázar, Ricardo Güiraldes, Silvina Ocampo, Leopoldo Marechal, Roberto Arlt, Ricardo Piglia, Osvaldo Soriano, Osvaldo Lamborghini) a quien homenajea en ensayos o cuentos. En El gaucho insufrible (2003), por ejemplo, hay una relectura/ reescritura de "El sur" en el contexto del 20 de diciembre de 2001 argentino. ${ }^{36}$

Bolaño ejerce la crítica literaria con decisión, osadía y desenfado, apelando a la amistad e invocando a sus compañeros de generación, una "crítica de camaradería". Frases como "el mejor de mi generación", "uno de los tres mejores de hoy" abundan como parte de un proceso de legitimación entre pares latinoamericanos y españoles contra todo "provincianismo" o "nacionalismo nefasto". Hay una cofradía latinoamericana -y española- a la que pertenece, desde donde se actualizan rituales de legitimación mutua. Un circuito cerrado que se hace visible en frases como "Aira el único comparable a Vila-Matas", "Villoro sólo comparable a Rey Rosa"; y que abarca a los argentinos Alan Pauls, Rodrigo Fresán, César Aira, los españoles Enrique VilaMatas, Javier Cercas, Antoni García Porta, el guatemalteco Rodrigo Rey Rosa, el salvadoreño Horacio Castellanos Moya, los cubanos Norberto Fuentes, Pedro Juan Gutiérrez, el mexicano Juan Villoro, hasta el peruano Jaime Bayly, entre otros.

Bolaño se sabe -a fines de los noventa- un escritor consagrado y se permite explorar los centros y márgenes de la literatura hispanoamericana desde $s u$ lugar en el campo literario chileno; es decir, desde el lugar que él mismo construyó a partir de sus constantes cuestionamientos e irreverencias ${ }^{37}$ a sus pares de Chile, y -por desplazamiento- a cierto circuito latinoamericano que, por cierto, reconoce como propio (“A primera vista componemos un grupo lamentable de treintañeros y cuarentañeros y uno que otro cincuentañero esperando a Godot, que en este caso es el Nobel, el Rulfo, el Cervantes, el Príncipe de Asturias, el Rómulo Gallegos”, 132).

Entonces, si Bolaño ancla su literatura en el 11 de septiembre de 1973 como parte de la generación que narra la "utopía derrumbada" (Cánovas), sin embargo se separará, tomará distancia y marcará su diferencia con el grupo más visible de la "Nueva narrativa chilena", el McOndismo de Alberto Fuguet y Sergio Gómez que

\footnotetext{
${ }^{36}$ En septiembre de 2007, la revista $\tilde{N}$ de Clarín publica como "tema de tapa" algunos textos sobre el "fenómeno Bolaño". Rescatamos el siguiente fragmento de Fogwill: "Pasé años atormentando a la redacción de El Mercurio y a los lectores chilenos por insistir en Bolaño como el mejor narrador argentino, fórmula que importunó tanto como el artefacto de Nicanor y su graffiti ¡Un hígado para Bolaño!" (Fogwill "La máquina literaria", Ñ, no 208, 22 de septiembre de 2007).

37 Otro ejemplo entre muchísimos, "La literatura chilena es una pesadilla sin vuelta atrás" (Entre paréntesis, 116)
} 
protagonizó el mini boom de los noventa. Demasiado vinculado al mercado y a la industria cultural, y cada vez más distante de los avatares que marcaron la historia chilena, este sector se aleja de los temas que interesan a Bolaño, quien en una entrevista opina que a Fuguet "se le escapa la historia", ${ }^{38}$ es decir la historia reciente, aquella que abarca desde Allende a Pinochet y que será el centro de varias novelas de Bolaño. Pero además, desde su residencia final en España, refunda su linaje literario vinculándose a escritores españoles y latinoamericanos, lo que le permite hablar de las derrotas que recorren América Latina y Europa.

${ }^{38}$ Entrevistado por Marcelo Soto, Qué Pasa, 20-27 de julio de 1998. http://www. quepasa.cl/revista/1423/24.html 


\section{III: FIGURAS DE ARTISTA: ESCRITURA Y VIDA, LITERATURA Y HORROR}

Para salir del aburrimiento, para escapar del punto muerto,

lo único que tenemos a mano, y no tan a mano, también en esto hay que esforzarse, es el horror, es decir el mal.

Roberto Bolaño, "Literatura+ enfermedad =Enfermedad"

Las escrituras del yo se instalan como un giro característico de los últimos años, tal como señalan varios críticos quienes desde diversas categorías -como "el giro autobiográfico" (Giordano 2008), "el giro subjetivo" (Sarlo 2007), "la autofiguración" (Amícola 2007), o "la era de la intimidad" (Catelli 2007)- indagan los modos, contextos e implicancias que "el paso de la vida a través de las palabras" (Giordano 2007) imprime en la tensión literatura y vida. Alberto Giordano advierte que el movimiento hacia lo autobiográfico no abarca indiscriminadamente todo texto que acuse la presencia de lo íntimo o las huellas del yo en la escritura sino que otras categorías parecen abrirse camino para dar cuenta de los nuevos modos en que insistentemente el yo autoral ingresa en la ficción. Como bien señala Julio Premat, surgen nuevas estrategias de supervivencia o resurrección del autor (2009: 24) ante su anunciada muerte. El concepto de autoficción, desde su nacimiento en Francia a partir de los reparos de Serge Doubrovsky (1977) al ya clásico e ingenuo "pacto autobiográfico" de Phillipe Lejeune (1975), ha desembarcado en América latina y caracteriza gran parte de la producción narrativa reciente (Alberca 2007), e incluso puede rastrearse un linaje rioplatense de larga data como demuestra José Amícola (2008) a través de las lecturas de Jorge Luis Borges, César Aira, Witold Grombowicz y Copi. ${ }^{39}$

Este contexto nos permite reflexionar en torno a las inflexiones de la narrativa de Bolaño en el empleo de las memorias y las biografías en sus textos en un doble sentido. Por un lado, es posible sondear las modulaciones del yo desde el impulso testimonial y la vocación por la memoria. Por el otro, nos permite indagar las vinculaciones que el escritor sostiene entre la literatura, la historia y la sociedad.

\footnotetext{
${ }^{39}$ Manuel Alberca (2007) arma su corpus de la autoficción española e hispanoamericana. En la lista figura Bolaño y se incluye a Estrella distante, Llamadas telefónicas, Los detectives salvajes y Putas asesinas.
} 
Cuando Beatriz Sarlo lee el auge del testimonio y la historia oral como una vuelta a la confianza en la primera persona (2007: 22) no sólo postula el "giro subjetivo" sino que lo enmarca en otra vuelta: la del pasado que se impone al presente en términos de irrupción, de asalto (2007: 9). Sarlo aquí cuestiona la retórica cristalizada del testimonio para explorar otros modos discursivos que abordan, desde lo estético, la dimensión biográfica y rescata, entonces, el potencial de la literatura para representar aquello sobre lo que no existe testimonio en primera persona (2007: 164). Aunque discuta las hipótesis de Sarlo, Diego Tatián (2008) se acerca a la idea de despojar al testimonio de los protocolos de un género. Tatián rechaza la impronta de la primera persona y el estatuto de la memoria como instancias que privilegian la afirmación de una verdad sobre el pasado porque el testimonio concierne al recuerdo y a la experiencia, no a la memoria en tanto construcción política y producto transmisible (2008: 52). Así, el testimonio puede no involucrar marcas personales de la subjetividad ni una oralidad que lo exprese (2008: 62). Es posible, entonces, articular otros modos en los que el recuerdo se convierta en experiencia testimonial. Estas cuestiones serán abordadas en el capítulo siguiente cuando analicemos las reconfiguraciones de la tradición testimonial que Bolaño plantea en novelas como Amuleto

Por su parte, el concepto de autoficción utilizado por la crítica en los últimos años se plantea como un espacio fronterizo e inestable entre la ficción y la autobiografía que supone, a través del "pacto autobiográfico" (Lejeune), que el yo que narra es "real" y se corresponde con la biografía del autor. La autoficción complejiza esta identificación al cruzar dos pactos de lecturas incompatibles (uno, dentro del orden de la verdad y el otro, en el orden de la verosimilitud). Esta categoría nos es útil para explorar las trazas a partir de las cuales el autor se transforma en personaje destacando así tanto los artificios de la escritura como las tretas de yo para construirse autor.

En su precursor estudio sobre la escritura autobiográfica, Silvia Molloy (1991) destaca el proceso de autofiguración del escritor que evoca el pasado condicionado por las necesidades del presente para edificar una imagen de sí funcional a las particularidades de la época y de un proyecto consciente. Se apunta así al proceso de configuración del yo a través de la escritura que Molloy lee en el siglo XIX. En este sentido, para la narrativa del presente se vuelve necesario destacar la diferencia que José Amícola (2008) advierte entre la autobiografía y la autoficción: si la primera devela una confianza ya anacrónica respecto de la autoridad de la voz narrativa, la autoficción se niega a aceptar un "yo monolítico y completo como un bloque sin fisuras" (Amícola 
2008) en el marco de las crisis del sujeto. Manuel Alberca (2007) respalda ese rasgo desestabilizador cuando reinscribe la fórmula que combina lo ficcional y lo biográfico en el concepto de "pacto ambiguo", que interpela al lector vacilante llevado a problematizar la relación entre ficción y realidad. En el "espacio biográfico" contemporáneo (Arfuch 2002) las formas de autoficción, donde autor, narrador y personaje coinciden en narrativas ficcionales, permiten reflexionar acerca de los modos en que el yo autoral ingresa en la ficción para articular figuraciones que dialogan con las diversas instancias que marcan lo literario en épocas determinadas y al mismo tiempo discuten y exploran los caminos en los que se cruzan la escritura y la vida.

Las discusiones críticas en torno a la autoficción destacan la dificultad que en tanto categoría presenta al momento de su definición y clasificación. Los estudios teóricos que intentan convertirla en un nuevo género (como Alberca) no abandonan el reconocimiento de la resistencia a la sistematización con la que nos enfrentamos al abordar textos literarios. No se trata, entonces, solamente de imponer rasgos genéricos sino de percibir los modos en que ciertos autores trabajan con matrices genéricas ya definidas (como veremos respecto del fantástico o el policial en Bolaño) o con nuevas combinaciones estéticas que atentan contra la idea misma de categorización o cristalización en formas prescriptas. ${ }^{40}$

Desde este núcleo teórico-crítico proponemos tres ejes de lectura para el Hipertexto-Bolaño. El primero tiene que ver con el modo más cabal en el cual la autoficción se presenta y corresponde a los desplazamientos de Bolaño autor hacia "Bolaño" personaje y que se deriva a otras nominaciones como Arturo Belano, Belano y B. En este marco, veremos cómo en varias de sus obras Bolaño autoficcionaliza ciertos momentos de su biografía que anclan especialmente (no son los únicos) en tres recorridos (espaciales y temporales) identificados con Chile, México y Barcelona, en el arco que va desde los años setenta a los noventa. Asimismo hay un interés por transitar ciertos espacios propios del escritor como la participación en los talleres literarios (en Chile y México), la inscripción a premios y concursos de literatura, los vínculos con las editoriales y la academia, y demás zonas que configuran una "biografía intelectual" y, en tanto autoficción, conforman una imagen de escritor asociada a lo melancólico, a lo

\footnotetext{
${ }^{40}$ Sobre la importancia de los géneros literarios, Bolaño (entrevistado por Dunia Gras) afirma: "Los géneros son la mejor plaza para que un artesano pruebe sus propias virtudes y sus propias excelencias. Para un escritor que pretende dominar algunos mecanismos del oficio los géneros literarios son un regalo de los dioses" (56) Gras Miravet, Dunia. "Entrevista con Roberto Bolaño", Cuadernos Hispanoamericanos, 604 (Oct 2000), 53-65.
} 
crepuscular junto con otros tópicos que exploraremos en los cuentos y en Los detectives salvajes.

Por otra parte, una segunda variante dentro de las "escrituras del yo" aparece en los retratos de escritores, en las pequeñas viñetas que conforman La literatura nazi en América desde la particularidad de recuperar figuras y perfiles de artistas infames como un modo peculiar de articular la literatura, el mal y el horror, donde también incluimos a Estrella distante. El interés en las relaciones con el mal y las reconfiguraciones del canon latinoamericano (Manzoni 2002, 2008) que las vidas de artistas en Bolaño escenifican, desde el humor y la irreverencia, manifiesta el constante juego de reescritura y desplazamiento también corrosivo de su propia estética, que hace trizas las complacencias del campo literario ilustrado y canónico, iluminando otras zonas de la biblioteca latinoamericana. A partir de La literatura nazi en América se configura una genealogía de la literatura del mal que edifica una tradición dentro del campo de la literatura. Se trata de una lectura hacia atrás que va enhebrando las diferentes emergencias de la literatura "nazi", desde luego en clave ficcional, y no sólo adquiere la dimensión de un análisis sincrónico sino también diacrónico y arqueológico.

El último núcleo se detiene en los silencios y huecos asociados a los crímenes de la historia de modo que exploraremos el uso de las memorias y de la confesión como géneros literarios que cobran una dimensión absolutamente nueva al situarse en las tramas del terrorismo de Estado. Bolaño recoloca estas formas en el espacio de la reflexión en torno a la imposibilidad de la amnesia, a la confesión de la complicidad y la culpa o al riesgo de elaborar el duelo. Estás cuestiones serán abordadas a partir de Nocturno de Chile en el siguiente capítulo (IV.1) donde Bolaño reinscribe la confesión como acto de exculpación que confronta razón y verdad a partir de la desesperación -de una crisis (Zambrano 1995)- y que en el contexto posdictatorial se tiñe de matices semánticos relacionados con la culpa, la mala conciencia, la justificación y el perdón. 


\section{1. Malas vidas: historias particulares de infames}

La literatura nazi en América (1996) reúne reseñas y relatos biográficos de hombres y mujeres de letras de variada procedencia en el continente cuya cohesión, además de la geografía americana, está dada por la adhesión -mayor o menor, consciente o inconsciente- a la derecha xenófoba, criminal e intelectual. La etiqueta "literatura nazi"41 que los aglutina puede referir tanto a una "simpatía" expresa por el nazismo (como los Mendiluce, que atesoran la foto de la pequeña Luz en brazos de Hitler) como a un compromiso más "activo" con la extrema derecha (como formar parte de los Escuadrones de la muerte latinoamericanos, combatir en el frente falangista, etc.). El amplio espectro de espacios, atravesados por las experiencias de la violencia política, va hilando el recorrido por las zonas oscuras de la biblioteca latinoamericana conformadas por figuras de artista que no constituyen un todo homogéneo. El arco se abre desde quienes pertenecen al engranaje del mal y no advierten del todos sus alcances (como Edelmira Mendiluce cuya frivolidad y estrechez intelectual le impiden dimensionar políticamente a Hitler) hasta aquellos que se involucran de lleno.

La seducción por el mal recupera el formato borgeano de Historia universal de la infamia (Manzoni 2006: 18) -y se inscribe en una genealogía elegida por el mismo Bolaño (2006)- ${ }^{42}$ pero aquí la infamia remitirá no sólo a las vidas de los personajes sino, sobre todo, a los oscuros vínculos entre cultura y poder. Las relaciones de la literatura con el mal no revisten un tono serio, por el contrario la mezcla de la burla y lo macabro satiriza la dimensión política o ideológica de los personajes y el nazismo que anticipa el título se vuelve un medio para desnudar las miserias y extravagancias de personajes literarios entre grotescos y nefastos. Borges acerca sus personajes infames a partir de la primera persona que relata sus vidas y rescata ciertas cualidades que los vuelven héroes, como la atroz sagacidad de Lazarus Morell (frente a la vulgaridad de un Al Capone), la lealtad de los cuarenta y siete capitanes del señor de la Torre o la velada valentía de

\footnotetext{
${ }^{41}$ Borges asume en el prólogo a Historia universal de la infamia que la palabra "infamia" ya "aturde" desde el título (2010: 10). Aquí, ocurre lo mismo con el fuerte sintagma "literatura nazi" vinculado además con América.

${ }^{42}$ Entrevistado por Dunia Gras, enumera: La sinagoga de los iconoclastas de Rodolfo Wilkock, el ya mencionado de Jorge Luis Borges, Retratos reales e imaginarios de Alfonso Reyes y Vidas imaginarias de Marcel Schwob (2006: 57).
} 
quien salva el honor de Rosendo Juarez. Bolaño, en cambio, los aleja al exagerar un vínculo extraño entre el ridículo, la trivialidad y el poder macabro de estos personajes.

Estas vidas imaginarias no sólo desplazan la retórica de la biografía de una idealización ejemplar ligada a cierta concepción de la historia basada en los triunfos y sus héroes sino que precisamente interpelan a la historia y sus vacíos. ${ }^{43}$ Así como la historiografía ha dejado de focalizar en lo que constituía las grandes glorias nacionales y recupera, en la línea de los debates en torno a la historia reciente, la presencia de las víctimas y los genocidios (antes que los héroes y la patria), la literatura, en un giro similar, explora la experiencia del mal, en sus alcances, en los sujetos y las estéticas. Este doble cruce de lo infame y lo imaginario que articula las vidas de La literatura nazi en América focaliza en un amplísimo muestrario de figuras de escritor que revela cómo los vínculos entre el mal y la literatura no determinan una estética particular sino que puede escurrirse en cualquiera.

La ironía, la exageración y la distorsión que armará el discurso biográfico del texto asoma en el epígrafe de Augusto Monterroso, de la novela Lo demás es silencio (1978):

"Cuando el río es lento y se cuenta con una buena bicicleta o caballo sí es posible bañarse dos (y hasta tres, de acuerdo con las necesidades higiénicas de cada quién) veces en el mismo río"

Aquí, el escritor guatemalteco (uno de los escritores favoritos de Bolaño, con quien comparte el tono burlón) se burla de las convenciones y discursos estancos de la literatura a partir de una supuesta biografía-homenaje del escritor Eduardo Torres. Asimismo, la "Heraclitana" de Monterroso refuta humorísticamente la doctrina del flujo y convierte el movimiento perpetuo en reiteración (es posible bañarse en el mismo río dos y hasta tres veces). Los argumentos absurdos que para Eduardo Torres posibilitan tal variación de la teoría de Heráclito (contar con movilidad propia, como el caballo o la bicicleta, y hacerlo por cuestiones higiénicas) permiten que la parodia transforme el principio del cambio por el de la repetición, de modo que anula la noción del flujo de la diferencia sin cancelar la idea de movimiento. Si aplicamos la repetición de lo mismo al

\footnotetext{
${ }^{43}$ Schwob elije esta perspectiva para sus "vidas imaginarias" configuradas a partir de los desechos más banales, como explica en el prólogo, a través del rescate y la exageración del "resto" abandonado por vulgar y por trivial. Así, la extravagancia junto con el detalle peculiar y excesivamente original hacen de una vida algo único (1980: 8-12).
} 
sintagma "literatura nazi" se explica la variopinta galería de monstruos que recorre diversos espacios y temporalidades y fermenta de distintos modos.

La literatura nazi en América es presentada como novela y podemos justificar la etiqueta si leemos cómo cada capítulo va armando el relato de la literatura y el mal en el mapa latinoamericano. Los capítulos se organizan en apartados bajo un título que puede ser descriptivo (como "Los Mendiluce, "Poetas norteamericanos") o sugestivo, como si fuese el título de alguna obra literaria, (como "Los héroes móviles o la fragilidad de los espejos" o "Dos alemanes en el fin del mundo"), los personajes pueden vincularse según los géneros que practican, los lazos familiares o los lugares de origen. Se reúnen relatos biográficos de variada índole, algunos son semblanzas que conectan vida y obra del personaje e incluyen datos insólitos para pincelar mejor su carácter y parodiar el género, un exceso de biografemas, el detalle singular que nos atrae (Barthes 1997). ${ }^{44}$ Otros son retratos más elaborados y dramáticos, en el sentido de que la voz de los biografiados se confunde (a través del discurso indirecto libre) con la de quien los retrata, y el texto final lo conforma un relato narrado en primera persona que se perfila como el más importante, no sólo porque cierra (con la voz de "Bolaño", ficcionalizado) sino porque deviene posteriormente en otra novela (Estrella distante).

El mapa que traza el texto no sólo cala en diferentes países latinoamericanos y también en Estados Unidos (y hasta España está presente) sino también en un diagrama temporal excéntrico que va hacia el futuro (algunos mueren en 2029 o 2021). Así, se arma una tradición literaria de la violencia a partir de los perfiles de escritores y escritoras filonazis que practican las más variadas estéticas, desde las retrógradas retóricas del nacionalismo de principios del siglo XX hasta las propuestas de la vanguardia más radical

El tono, lejos de abrazar totalmente lo macabro, se constituye en el humor de la ironía y la parodia, especialmente a partir de la paradoja, la contradicción o simplemente lo descabellado. El detalle trivial incluido en el resumen de una vida, por ejemplo, o las paradojas que colocan la incongruencia en un mismo plano ${ }^{45}$ son procedimientos que develan los sórdidos mecanismos sobre los cuales se constituyen las literaturas nacionales, por ejemplo, iluminando las zonas grotescas de la poesía

\footnotetext{
44 "Aprendió a montar a caballo" (13 ) o "Llegó a Creta un mediodía de primavera" (14)

45 Como la descripción de Franz Zwickau, un "muchacho talentoso con mirada de un asesino o un soñador", (91). También la exagerada fijación del joven poeta venezolano por los campos de concentración se manifiesta en una obra que pese al título ser Campo de concentración se nos informa que el contenido narra con humor y ternura la primera infancia del escritor (92).
} 
gauchesca, o ridiculizando al revolucionario cubano. Así, quedan al desnudo los presupuestos ideológicos y estéticos que han forjado el canon de las altas letras americanas, presupuestos que tradiciones posteriores matizaron u ocultaron. El amplio espectro estético trabajado revela una zona de escritores conservadores, oligarcas, filonazis que se vinculan en mayor o menor medida con las formas del mal pero cuyas estéticas no determinan su ideología ni viceversa: el mal puede crecer en cualquier parte.

Nos interesa focalizar en la saga de Los Mendiluce que abren la galería infame en tanto arma un relato que sintetiza una temporalidad significativa y se vuelve paradigmática al recortar y calar en momentos precisos. El relato traza un arco significativo que va desde el nacionalismo de los años veinte (y posteriores) hasta 1976. El origen constituye un completo cuadro que traza los rasgos constitutivos de la literatura (argentina y nacionalista) de élite en los albores del siglo XX hasta el final, con la muerte de Luz, marcado por el Golpe de estado más cruento de 1976. Edelmira Thompson de Mendiluce reviste el dejo del nacionalismo romántico de los primeros años, y encarna por momentos los resabios bohemios de la generación consolidada en el modernismo configurando, así, las diferentes etapas que los primeros pasos de las letras de la patria recorren. ${ }^{46}$ Mientras que sus hijos, Juan y Luz, abrazan el nacionalismo desde una literatura de tintes vanguardistas. El impulso civilizatorio que sostienen colisiona con el ideal democratizador de la cultura que parecen pregonar cuando abiertamente defienden el nazismo o el falangismo. Bolaño recuerda los pilares civilizatorios de las letras nacionales sostenidos en la marginalización o aniquilación del otro al mismo tiempo que propone otro canon si se quiere más sincero: el de la infamia, la xenofobia y el crimen. Los nefastos valores explícitamente defendidos por los Mendiluce (y todas las figuras biografiadas) que ese mismo afán iluminador apenas ocultó (al fin y al cabo son vidas al margen) se hacen visibles en este catálogo y desenmascara -e imagina- cómo se va haciendo la literatura.

Edelmira condensa los tópicos de iniciación en la escritura que la cultura letrada tradicional adopta y sus formas de sociabilidad y consagración (tales como los salones literarios, el viaje a Europa y una acomodada posición económica). Es decir, pone en primer plano una actividad literaria basada en prácticas sociales elitistas, cuya impronta política de cuño conservador enmarca los debates sobre el canon y la constitución de la

\footnotetext{
${ }^{46}$ Algunos críticos han querido ver a Victoria Ocampo en este perfil cursi de escritora (apelando a su papel de promotora y mecenas de la cultura y a su "enfrentamiento" con Eva Perón).
} 
nacionalidad. Pleno exponente de una sociedad patriarcal, la primera obra de Edelmira se titula A papá, y es, por supuesto, de corte autobiográfico. Desde la prensa nacional, el crítico Belmar la desestima y la coloca en el lugar que corresponde a una dama de la alta sociedad: la beneficencia y la educación. Edelmira contraataca y parece entender a la perfección las leyes del incipiente campo literario, entonces deja la contemplación amorosa, se suma a las huestes nacionalistas de principios de siglo XX e inspirada en los trabajadores del campo "quiere una literatura épica, epopéyica, a la que no le tiemble el pulso a la hora de cantarle a la patria" (15), frase en la que resuenan las palabras clave en la obra de Leopoldo Lugones como La hora de la espada. El éxito no tarda en llegar y se constituye como la gran promotora de las artes y nuevos talentos, funda revistas y editoriales.

La biografía de Edelmira que abre el libro permite desandar "el mapa nocturno" (Romano 2010: 48) de las letras americanas a través de trayectorias individuales. En los preludios de la década del treinta, los Mendiluce conocen a Hitler en consonancia con un clima de época (la aparición de grupos xenófobos que abrazan primero el facismo, luego el nazismo). Edelmira reproduce las dos poéticas dominantes que Eduardo Romano (2010) sintetiza para la literatura argentina en las primeras décadas del siglo $\mathrm{XX}$ : del nativismo al esteticismo. Edelmira se consolida un "lugar al sol en la literatura argentina e hispanoamericana" (Bolaño 1999: 17) con la publicación de La habitación de Poe que coincide con el comienzo de la Segunda Guerra. Esta obra que se presenta como la precursora de las vanguardias posteriores (17) es un texto que reconstruye (a modo de instalación) y reescribe (en un gesto con ecos de Pierre Menard) un cuarto que Edgar Allan Poe incluye en el ensayo "Filosofía del moblaje". Mientras el público parece no comprender su excesivo interés por la decoración de interiores y el aporte que esto constituiría a la literatura, Edelmira recibe nazis fugitivos que desembarcan en las playas argentinas (21). Edelmira termina sus días recluida en la habitación de Poe y prefigura subrepticiamente el relato final de La literatura nazi en América. La obsesión por el detalle permite la reproducción total del cuarto, en el camino inverso que va del texto a la vida (sin vida, es un cuarto repleto de objetos) y borra los límites entre ficción y realidad. La habitación, sobre todo cuando ya se ha mencionado a Poe, activa las posibilidades del mal en el espacio cerrado que hará sistema con la habitación que Ramírez Hoffman transforma en locus horrendus al exponer las fotografías de la tortura y la muerte. 
A diferencia de su madre, Juan Mendiluce no oculta sus ideas y actividades políticas que sobrepone a la práctica literaria. La sombra de Leopoldo Lugones se proyecta en la biografía de Juan, el Catón argentino (25), quien ocupa cargos públicos en Córdoba y Buenos Aires, y atraviesa el más variado espectro político-ideológico (falangista y seguidor de Primo de Rivera, antinorteamericano, anticapitalista, pro norteamericano, peronista, nacionalista católico, pro militar). Le cabe (como a otros personajes biografiados) la síntesis que Miguel Dalmaroni anota para Lugones desde la moral de la revista Sur (o el canon dominante): un escritor "políticamente inmoral y literariamente impresentable" (2003: 19). ${ }^{47}$

Se van conformando entonces los rasgos que unifican esta galería de monstruos letrados: cierta (y breve) preminencia en el ámbito cultural, destacada participación en lo político, claras filiaciones ideológicas y producciones de obras escasamente leídas. Son personajes que literariamente convocan a un grupo reducido de lectores, seguidores o admiradores y, sumado a eso, la síntesis de sus vidas culmina en el margen, el olvido y la tragedia (algunos son asesinados, otros se suicidan o mueren en algún manicomio o asilo, en combate o en accidentes fatales) ${ }^{48}$ constituyendo nuevas encarnaciones del artliano escritor fracasado.

Luz Mendiluce, la hermana atormentada de Juan, asume otro de los derroteros de las letras americanas ligado a la vanguardia experimental. Luz lleva una vida repleta de excesos (llega a pesar cien kilos- mide 1, 58, bebe una botella de whisky al día, 29) y sus poemas (como "Stalin" en Con Hitler fui feliz) manifiestan una mezcla de vodka, humor negro y alaridos. Es la niña descarriada de la familia y del sistema literario a quien sigue un reducido grupo de "problemáticos" jóvenes. ${ }^{49} \mathrm{La}$ articulación entre nacionalismo y vanguardia vuelve en las décadas del setenta y ochenta bajo la conjunción de arte y horror. Así, los poemas de Willy Shürholz, superando los caligramas, son verdaderos planos topográficos de Auschwitz, Bergen-Belsen o Buchenwald y el gesto vanguardista es llevado al extremo con sus performances en los desiertos de Atacama (y Arizona) donde excava el plano de un campo de concentración

\footnotetext{
${ }^{47}$ Además de Una república de las letras (2006) remitimos al artículo donde Dalmaroni retoma hipótesis anteriores para plantear un relectura de la figura de Lugones ("El juicio del siglo: Leopoldo Lugones revisitado”, 2010). La síntesis que la agudeza crítica de Dalmaroni elabora bien podría formar parte de algún capítulo bolañano en las biografías de la literatura de escritores infames.

${ }^{48}$ Aquí sí las biografías de Bolaño comparten el interés de Foucault por rescatar del olvido las vidas infames de seres marginados.

49 “ Para los nazis y los resentidos, para los alcoholizados y los marginados sexual o económicamente Letras Criollas se convierte en punto de referencia obligado y Luz Mendiluce en la gran mamá de todos y en la papisa de una nueva poesía argentina que la sociedad de las letras, asustada, intentará aplastar" (29).
} 
ideal, acompañado por una "parte literaria" (las cinco vocales) que sólo puede leerse desde el aire, (“el evento no tarda en ser la sensación del verano cultural chileno", 98). Su maestro es el poeta Carlos Ramírez Hoffman que se nos presenta en La literatura nazi y terminamos de conocer en Estrella distante.

Las historias de estos personajes escritores dan cuenta de diferentes momentos, estéticas y tópicos de la intelectualidad americana que se distorsionan vistos a través del prisma del subgrupo "literatura nazi", junto con lo funesto y lo grotesco. Como ya adelantamos, el título agrupa diferentes figuras de escritor y no determina ninguna estética en particular. Así, la inclinación filonazi más que estancarse en proclamas político-ideológicas se acerca al crimen, la xenofobia o el nacionalismo nefasto en distinto grado como un germen que se propaga, contamina y puede aparecer en cualquier parte. Así, es evidente la ruptura con toda idea de que una estética sostenga una ideología, la "literatura nazi" puede abarcarlo todo. Al nacionalismo y la vanguardia se suma el realismo socialista del cubano Ernesto Pérez Masón que, mezclado con Kafka y el decadentismo, produce novelas que ocultan acrósticos como "Viva Adolf Hitler" o "Mierda de paisito"(58). Perez Masón pretende sin éxito ser reconocido en el grupo Orígenes a través del duelo que intenta batir contra Lezama Lima, pero éste lo ignora en extremo. Los poetas estadounidenses también tienen su lugar en las páginas xenófobas de Jim O’Bannon y Rory Long, al margen de los círculos vanguardistas de los cincuenta (los beatniks o los poetas del Black Mountain), y en los miembros de la Hermandad Aria, élite intelectual de las cárceles del norte. Incluso las voces caribeñas y sus intelectuales de la negritud tienen su representante infame con Max Mirebalais, militante del plagio (calcó a Césarie, a Depestre, a Glissant, a todos), cuyos cuatro seudónimos esconden el proyecto ambicioso de "formar él solo la poesía haitiana contemporánea" (129). El brasileño Amado Couto piensa en el secuestro de Rubem Fonseca pero sólo escribe novelas policiales y trabaja en los Escuadrones de la Muerte, secuestrando y torturando. Se escriben así las páginas de la literatura nazi en América que parece ser producto de la aleación entre literatura y nacionalismo. ${ }^{50}$

\footnotetext{
${ }^{50}$ Bernardo Subercaseaux (2010) analiza el contexto chileno del nacionalismo cultural a principios del siglo veinte que resumimos con su comentario de Raza chilena (1904) de Nicolás Palacios pues podría también formar parte de las reseñas bibliográficas de los personajes de Bolaño: "La única inmigración que resultaba aceptable era, para el autor y sus seguidores, la germana, puesto que era la única que reafirmaba la antigua herencia goda y sus virtudes guerreras. Las ideas de Palacios, aunque estrafalarias desde el punto de vista de la etnohistoria, resultaban funcionales a un proceso de mitificación del roto chileno, que databa desde la Guerra del Pacífico. Coincidían además con un proceso que se daba en otros países del continente: la incorporación del otro, del bárbaro, de la alteridad al imaginario republicano de la nación, a un nuevo "nosotros", ya fuera a través de la ideología del mestizaje y de la "raza cósmica",
} 
Más allá de una ideología y prácticas criminales concretas, el nazismo aparece en la literatura desde figuras menores con aires de grandeza y afán de posicionarse como representantes de las letras en sus respectivos países. Es por eso que las poéticas de estos escritores y escritoras son el envés grotesco (o pueden ocultarse detrás) de la poesía gauchesca rioplatense, del realismo socialista cubano o de la poesía de la negritud caribeña. Asimismo los géneros populares tienen sus tipos nacionalistas, como el policial en Brasil o la ciencia ficción en Estados Unidos. Los imaginarios culturales que amplían el entramado de la patria y los proyectos literarios que lo consolidan incluyen a los sectores populares llevados al extremo con los aportes de los "fabulosos hermanos Schiaffino", de cuna inmigrante (Ítalo y Argentino) en el tradicional barrio argentino de la Boca quienes además de poetas son líderes de la barra brava de Boca Juniors. También, en el otro extremo, se incluyen las obsesiones de la crítica académica centrada en las correspondencias entre vida y obra o las estéticas de un academicismo inútil ligado a la filosofía que vanamente intenta explicar al sujeto o interpretar al mundo (como la serie de "Refutaciones" a diferentes filósofos de Luiz Fontaine Da Souza, casi todas superan las 600 páginas, o su Crítica a "El ser y la nada" de Sartre, de seis volúmenes y otros tantos apartados).

Los temas borgeanos que la "literatura nazi" pone al desnudo (las biografías imaginadas, los reparos a una literatura nacional) para implosionar el centro mismo del campo literario y pensar las relaciones entre la historia, el mal y la literatura llegan al límite de sus posibilidades en su bifurcación final: el relato que narra a Ramírez Hoffman, el infame. Aquí, el tono paródico se desvanece para dar lugar al relato que desde el recuerdo de un narrador en primera persona se acerca más al testimonio y veremos que adquiere los contornos de la autoficción. ${ }^{51}$ El recuerdo nunca es factualmente veraz y la incertidumbre ${ }^{52}$ será la evidencia del lenguaje que ensaya cómo articular el horror desde un relato que paradójicamente -o no- da cuenta de quien supo conectar literatura y vida (y muerte). El relato de Ramírez Hoffman establece un quiebre

\footnotetext{
como ocurrió en México, o a través de un "otro" que se reconocía como parte de la nación: como ocurrió con el gaucho en el Río de la Plata y con el cholo en los países andinos. La diferencia es que Palacios homogeneíza y europeíza al "otro", lo transforma en una suerte de "proto-germano"' (68).

${ }^{51}$ La primera persona del narrador aparece desde el comienzo marcando distancia respecto de lo narrado (y a partir de un dato que tiene que ver con "lo chileno", la distancia adquiere otros matices cuando luego ese narrador se identifique como "Bolaño"): "la palabra pololear me pone la piel de gallina" (177, cursivas nuestras para destacar el chilenismo).

${ }^{52}$ Algunos ejemplos: "digamos dos semanas después o un mes después" (178); "y luego degüella a la tía, no, le clava un cuchillo en el corazón" (179); "y no hay cadáveres, o sí, hay un cadáver" (179); "todo lo anterior ocurrió así. Tal vez no." (186).
} 
con el resto de libro y a su vez se convierte en el umbral de entrada a la novela Estrella distante que será otro modo de abismarse en los vínculos entre la literatura y el mal. Esta novela será una continuación del núcleo de su predecesora, pero también será un desvío abrupto que se internará en la desmesura de la violencia extrema.

Las figuras banales de los escritores del mal en La literatura nazi en América tienen como trasfondo las zonas más evidentes del nacionalismo que algunos de estos artistas infames ponen en evidencia desde el lado grotesco de las versiones latinoamericanas de la vanguardia atravesadas por el tema de la identidad nacional (las vanguardias enraizadas que Roberto Schwartz sistematizó en su clásico estudio). En la historia de Ramírez Hoffman -Carlos Wieder en Estrella distante- la cuestión de lo nacional se verá desplazada -pero no abandonada- porque el foco será indagar cómo se articulan literatura (o las posibilidades del arte de vanguardia) y violencia extrema en una propuesta radical y macabra. 


\section{2. Una temporada en el infierno: Estrella distante}

La novela Estrella distante es “espejo y explosión” (Bolaño 1996: 11) del capítulo "Ramírez Hoffman, el infame" tal como el narrador "Bolaño" anuncia en el borgeano "prólogo". Aquí conocemos que la fuente de la historia es el relato que un tal Arturo B. contó para luego ayudar a componer su versión expandida (junto con "el fantasma cada día más vivo de Pierre Menard", 11). Los acontecimientos narrados transcurren la mayor parte en el Chile de la dictadura pinochetista, sin embargo los abismos hacia los que nos conduce el tema principal de la novela exceden la inclinación a fijar el referente histórico. Por ello, con el fantasma también vivo de Emma Zunz pareciera que "las circunstancias, la hora y uno o dos nombres propios" (Borges 2011: 79) pueden ser falsos pero verdadero es el mal absoluto que Wieder intenta articular con el arte. Si sostenemos que el quiebre que supone esta historia respecto de sus vecinas en La literatura nazi en América no está dado solo por el tono sino por la fuerte presencia del yo narrador es desde la autoficción que se propone indagar diversas zonas de asedio al nudo problemático de la literatura y el mal. En general, esta relación puede abordarse a partir de los debates acerca de los modos de narrar el horror, la violencia extrema y la abyección tan intensos durante el siglo XX. Sin embargo, el núcleo que intentamos abordar aquí es de otra índole, no interesa tanto cómo es posible representar el mal sino la pregunta es cómo hacer literatura con él. El mismo Bolaño explicó que se trata de una aproximación al mal absoluto, antes que su mera representación. ${ }^{53}$

Nos interesa leer la novela a través de tres núcleos complejos que exploran cómo en esa zona intermedia que posibilita la autoficción se arma el relato del mal y sus alcances. En primer lugar, la autoficción es el punto de partida para articular testimonio y ficción a través de un vínculo particular que corroe la opción del testimonio como fuente de la verdad. Este gesto advierte cómo Bolaño realiza una apuesta muy fuerte a la ficción para reinscribir el "acto testimonial", cuyo hilo vertebrador se mantiene, contra el "testimonio como documento". El privilegio de la ficción permite explorar el vínculo entre arte y mal lo que constituye el segundo núcleo de la novela. La compleja figura de Carlos Wieder es la puerta de entrada para abordar el mal como proyecto artístico.

53 “En Estrella distante intento una aproximación, muy modesta, al mal absoluto." (2004: 20) 
Wieder es ante todo "un artista del mal", es un poeta que instala una voluntad del arte a través de la muerte. De manera que sólo el impulso transgresor de la vanguardia que, como señala Peter Bürger, articula arte y vida le permite llevar hasta el extremo el vínculo entre el mal y la literatura a partir de un contundente proyecto artístico que, como dijimos, une arte y muerte.

Por último, es posible ver en el texto un oscuro escenario de justicia que se da en la activación de los códigos del policial. Hay una zona que trabaja con la cuestión del crimen y el castigo que instaura en el texto una demanda de justicia en consonancia con el género policial (quien halla la pista para atrapar al asesino es el escritor) que de ningún modo es heroica ni limpia sino que por el contrario abre una "zona gris" (Levi) de múltiples y complejos alcances.

La anécdota comienza en los talleres de poesía que proliferan durante el gobierno de Salvador Allende y que sistemáticamente serán desarticulados con la dictadura. Aquí la presencia del narrador es más fuerte porque apela a la verdad del testigo: yo estuve ahí, yo sé lo que aconteció. Por un lado, lo testimonial se constituye a partir del yo narrador "Bolaño" que da cuenta de la experiencia de la violencia que sufrió toda una generación, la suya, ante la derrota revolucionaria poniendo el foco sobre todo en la destrucción de la poesía. Por otro lado, la tensión inherente al pacto ambiguo de la autoficción desata diferentes quiebres que afectan al testimonio desde la ficción al corroer la capacidad de apuntar a lo real. Las dudas del narrador, el espejeo de narradores, la multiplicidad de las fuentes y el juego de los dobles se instalan como modos de presentar el vínculo autoficticio que une testimonio y ficción como un pacto atravesado por la incertidumbre que socava la veracidad del testimonio como fuente pero rescata el "acto de testimoniar" para dar cuenta del mal.

El testimonio del mal puede enraizarse entonces en las circunstancias específicas que marcaron la historia de Chile (hay datos que permiten anclar el texto en tiempo y espacio: nombres, fechas, acontecimientos históricos y hay imágenes que permiten esa lectura: la bandera chilena aludida en el título) que se abre a la historia de América Latina en los setenta. Sin embargo, el texto no se detiene allí y privilegia la ficción para adentrarse en el nudo principal que marcamos al comienzo: la literatura y el mal. El valor testimonial de la veracidad se desestabiliza cuando la sustancia misma de la ficción se rebela contra la rigidez del documento y los significados acabados. Lo auténtico surge del espesor del recuerdo del yo narrador quien articula la voz 
testimonial (la propia y la de una generación) con la búsqueda de la palabra que le dé forma (en la escritura). ${ }^{54}$

La ambigüedad que genera la desconfianza hacia el yo narrativo de la autoficción se nos impone desde la primera línea: "La primera vez que vi a Carlos Wieder fue en 1971 o tal vez en 1972" (11, cursivas nuestras). El relato se propone a través del recuerdo narrar la historia de Carlos Wieder para lo que el narrador evoca los años de juventud cuando compartió los talleres de literatura de Juan Stein y Diego Soto. La memoria como principio constructivo en vez de otorgar las certezas del yo protagonista y testigo las socava y deviene vacilación, incertidumbre. Las primeras páginas, casi siguiendo la convención narrativa, nos introducen en tiempo (los primeros setenta, el Golpe militar encabezado por Augusto Pinochet contra el gobierno socialista de Salvador Allende) y espacio (el sur de Chile, la escena literaria joven entre talleres literarios y partidos políticos) y al presentar los personajes se abre la grieta del vacío que produce la figura de Alberto Ruiz-Tagle (identidad de Carlos Wieder durante esa época). El narrador evoca las diferencias de Ruiz-Tagle con el grupo como recortándolo del fondo común ${ }^{55}$, lo singulariza con la marca del enigma: "Nadie lo conocía" (22), y nadie puede ver lo que realmente se mueve detrás (sólo la Gorda Posadas quien intensifica el secreto) (22). Con la dictadura se consolida el nudo del relato que sugiere que develará el secreto y es entonces cuando el narrador se sincera y nos dice que su relato "se nutrirá básicamente de conjeturas" (29).

El proceso de reconstrucción de la historia de Wieder comprende la memoria del narrador a la vez que incluye un juego de fuentes junto con el espejeo de subjetividades que se duplican. La autoridad del yo que narra se ve trastocada no sólo a partir de la desconfianza en el relato que él mismo parece reconstruir sino en la acción misma de hacerlo. Es decir, la escritura del texto involucra a diversos sujetos que se ocultan tras la primera persona narrativa. Sabemos por el antecedente contenido en La literatura nazi en América que el yo que narra corresponde a "Bolaño", esta ficcionalización del autor

\footnotetext{
${ }^{54}$ Anna Forné (2010) propone la denominación "autoficción testimonial” para leer los textos que en el Cono Sur conjugan "en mayor grado el anclaje colectivo e histórico y la responsabilidad social con la faceta de imaginación interpretativa” (72). Ver también: Dalmaroni (2004).

${ }^{55}$ Los jóvenes hablan según sus afiliaciones políticas, viven con sus padres, carecen de dinero; mientras que Ruiz-Tagle parece fuera del tiempo, utiliza un español de ciertos lugares que parecen detenidos, vive solo, nunca le faltó el dinero (16). Es como si la distancia entre ellos intensificara, en los años previos al horror, los diferentes caminos que tomarán los personajes durante (y después) de la dictadura. Esto se anticipa en la visita de Bibiano O'Ryan a la casa de Ruiz-Tagle que, bajo la comparación con una escena de la película El bebé de Rosemary, apunta a lo inefable demoníaco pero "presente, tangible", el horror que mostrarán las fotografías también se anuncia cuando esa falta (lo que no puede decirse pero está) se describe como "si el anfitrión hubiera amputado trozos de su vivienda" (17).
} 
se confirma en Estrella distante a través de ciertos datos que cualquier lector de Bolaño reconoce como su relato autobiográfico "autorizado" (aprobado y reproducido por el mismo autor): pertenece a la "generación nacidos en el cincuenta", juventud dedicada a la poesía, cierta militancia de rigor, detención en Chile, problemas hepáticos, entre otros. Aquí se apela al dato biográfico que le otorga un valor de verdad al texto (y es lo que además lo ata al referente histórico). Sin embargo, las certezas se esfuman desde el breve prólogo que ya mencionamos donde se nos informa que la historia fue dictada por Arturo B. (chileno, "veterano de las guerras floridas y suicida en África", 11) con quien "Bolaño" comparte autoría.

Contra la parálisis de un yo unitario, la autoficción de Bolaño disemina el sujeto autor hacia diversas figuras de autor que lo narran en diferentes facetas, desde distintos puntos de vista develando la "nadería de la personalidad" pero reafirmando a su vez el peso específico del escritor. Esa difusión de figuras autorales que comparten datos biográficos con quien firma los textos genera la sensación de que Bolaño no es ninguno y es todos a la vez; sin estar, su fantasma recorre cada uno de los textos que conforman su obra. En Estrella distante, esta duplicación -o multiplicidad- autoral ("Bolaño" y “Arturo B.”) aumenta cuando conocemos buena parte de las fuentes de la historia: las cartas que Bibiano O’Ryan envía al narrador, quien además en los setenta publica El nuevo retorno de los brujos, un ensayo sobre los movimientos literarios fascistas del Cono Sur (117) constituyéndose así en el autor de La literatura nazi en América cuyas páginas aún no han sido escritas, aumentando así la confusión. ${ }^{56}$

La cuestión del doble está en la raíz misma de esta autoficción que prolifera en sujetos que son espejos del autor (quien crea sus dobles ficcionales) y es uno de los procedimientos más visibles en Estrella distante. ${ }^{57}$ Ya indagamos el juego de espejos del narrador que involucra a diferentes funciones en la tarea de contar la historia. Respecto de los personajes, las duplicaciones en la primera parte de la novela (el narrador y Bibiano, dos talleres, las gemelas Garmendia) pueden enfrentarse al solitario Ruiz-Tagle (que sin embargo tiene doble apellido). También Ruiz-Tagle se configura como el doble rival para Bibiano y el narrador que disputan el amor de las hermanas

\footnotetext{
${ }^{56}$ Esta identificación (Bolaño, Arturo B., Bibiano) ya ha quedado establecida en páginas anteriores cuando se cuentan los proyectos de Bibiano, entre los cuales está "escribir un libro, una antología de la literatura nazi americana" (52)

${ }^{57}$ Para Celina Manzoni (2002) la poética del doble permite dar cuenta de los horrores de la historia sin caer en la retórica fácil de la denuncia. ${ }^{57}$ En la misma línea se ha analizado a los personajes a partir de los distintos derroteros que sus vidas figuran como diferentes perfiles dentro de un mismo horizonte: el de una generación, de la que Wieder se recorta como su posibilidad más nefasta (Gamboa Cárdenas y Fisher 2008)
} 
Garmendia. El motivo del doble apunta entonces a la dualidad y a la repetición (como descubre Bibiano en la etimología alemana del nombre "Wieder" que puede significar "otra vez, nuevamente" y "monstruosidad, aberración", 51) y establece una zona ambigua que inscribe la tensión de lo real atravesado por la ficción. Las historias que narran las vidas de Juan Stein y Diego Soto se integran como otros ejemplos que dan cuenta de la oscilación entre la voluntad de testimoniar y la construcción del relato que impone la ficción para narrar las experiencias de una juventud marcada por la violencia.

Los relatos intercalados, entonces, forman parte del juego de espejos de la novela y de su estructura (que se arma en el "contar intercalando": recuerdos, fuentes, cartas, historias). Las vidas de Juan Stein y Diego Soto bien pueden formar parte de otro capítulo en el relato de la juventud latinoamericana de los setenta. A la participación en los talleres de poesía en los años previos a la dictadura militar, se le añade el recorrido de la lucha revolucionaria y el camino del exilio como dos nuevos perfiles dentro del testimonio generacional. Ambas historias resumen biográficamente sus últimos días y reafirman la apuesta estética de la novela en su conjunto plagada de digresiones, incertidumbres y ambigüedades. ${ }^{58}$ Stein, o más bien su fantasma, recorre el mapa latinoamericano e incluso africano de las revoluciones y puede haber muerto en una de las últimas ofensivas de la guerrilla salvadoreña. O también, pudo haberse dedicado a arreglar motores y haber muerto de cáncer en la tranquilidad de su pueblo.

Diferentes fuentes, que Bibiano rastrea, bifurcan la vida de Stein en dos finales antagónicos, en varias lecturas para una vida. ${ }^{59}$ La foto del general del Ejército Rojo Iván Cherniakovski, tío lejano de Stein, despliega una serie de datos sobre la Segunda Guerra, que no sólo pone en evidencia el conocimiento sobre cuestiones bélicas del narrador $^{60}$ sino que culmina en el rescate de la importancia de la foto (por desplazamiento, del arte) por sobre el dato verificable de las calles, bustos y ciudades que conmemoran a Cherniakovski. La misma lógica sigue la mención a la imagen de William Carlos Williams (que podía reemplazar al tío en el portarretrato) a partir de las discusiones en torno a la autenticidad de la misma. La obsesión por el detalle y la digresión que éste genera también abre una puesta en abismo del movimiento estético de la novela que socava el dato testimonial con la fuerza desestabilizadora de la ficción.

\footnotetext{
${ }^{58}$ (Y del Hipertexto-Bolaño)

59 La idea de estar ante la elaboración de una vida, su construcción antes que su reconstrucción se explicita en el siguiente comentario del narrador: "(en la distancia su ferocidad, su implacabilidad se agigantaba y distorsionaba como la de un personaje de una película de Hollywood)" (69).

60 Otro guiño a la autoficción de Bolaño que nos lleva a El Tercer Reich o "La parte de Archimblodi" de 2666.
} 
La historia de Diego Soto, por su parte, perfila otro derrotero en la construcción del relato latinoamericano de los setenta. Si anteriormente se trazan las huellas del guerrillero heroico, aquí se pone el foco en el exilio y sus derivas: "el triste folklore del exilio -en donde más de la mitad de las historias son falseadas o son sólo la sombra de la historia real" (75). La elocuente cita ya cifra la imposibilidad de conocer "la" verdad del relato. En las antípodas de uno de los Stein, Soto da rienda libre a su aburguesamiento y se asienta en París donde vive una vida tranquila, de profesor universitario y padre de familia. Nuevamente, diversas fuentes nos aproximan a su tranquila existencia pero el procedimiento se hace trizas contra la información transcripta a partir del detalle irrisorio. Los indicios barthesianos más que provocar un efecto de lo real denuncian el artificio de modo que la veracidad de la fuente testimonial se pulveriza. Por ejemplo, conocemos los últimos movimientos de Soto -de Alicante a París- según diversos testimonios como el del camarero; nos enteramos de su última cena con la precisión del informe forense (esta fuente nos anticipa la tragedia); sabemos, por el doblez de la hoja, en qué página había interrumpido su lectura. Por último, se enfrenta borgeanamente a la muerte ${ }^{61}$ y su muerte entonces se transforma al mismo tiempo en relato, afirmado por la carta de Bibiano quien refiere su muerte al narrador “casi como el informe de un detective" (80). La idea de que el sino trágico de una generación une a estos personajes está en la reflexión del mismo narrador cuando finaliza la historia de Lorenzo/Petra, el homosexual sin brazos, el poeta mendigo o la acróbata ermitaña que fue modelo de la mascota olímpica española.

El juego de multiplicaciones que los sujetos y las voces del relato asumen carcome la posibilidad de instalar el testimonio como opción estética para dar cuenta de la experiencia del mal. Planteamos cómo la autoficción testimonial construye otros modos de significar un pasado violento a partir de la tensión entre lo verificable y lo imaginado de la experiencia. Esta ambigüedad también desata el relato más profundo que explora simbólicamente los nudos problemáticos de la literatura y el mal a través de la figura de Carlos Wieder.

\footnotetext{
${ }^{61}$ María Luisa Fischer bien evoca "El sur" de Borges y describe la muerte de Soto como el encuentro "con un destino sudamericano menos nostálgico" (Fischer 2008: 156), pero no menos literario: "a Soto se le llenan los ojos de lágrimas, lágrimas de autocompasión, pues intuye que ha hallado su destino. Entre Tel Quel y el OULIPO la vida ha decidido y ha escogido la página de sucesos" (Bolaño 1996: 80). Agregamos otro intertexto borgeano "Biografía de Tadeo Isidoro Cruz", más esclarecedor que el de Dahlmann, porque Soto, como Cruz, finalmente acata su destino (el del relato setentista del "héroe" latinoamericano): "Cualquier destino, por largo y complicado que sea, consta en realidad de un solo momento: el momento en que el hombre sabe para siempre quién es” (Borges 2011, El aleph, 69).
} 
Carlos Wieder es ante todo un poeta que no manifiesta tanto una fascinación por el mal como la voluntad de hacerlo y, sobre todo, crearlo a partir del arte. Cuando Georges Bataille elige sondar cómo el mal se introduce en la esencia del arte antes que describir sus manifestaciones arma una constelación de figuras cuyo arte convoca la muerte, el mal o la violencia para despojarse de los límites insoportables de la vida. Sólo la literatura puede desnudar la transgresión de la ley y quebrar el principio vital que aleja al ser humano de la región de la muerte (99). Cuando indaga la fascinación por el mal que Baudelaire proclama advierte que el poeta no participa de él, dice casi con Kant que no tiene la voluntad del mal (92). Wieder no podría compartir las páginas de Bataille sobre Brönte, Kafka o Blake porque él mismo encarna el mal que el filósofo francés quiere leer en la literatura. Una de la percepciones recurrentes del narrador sobre Wieder describen una "voluntad sin fisuras" (53), incluso antes del encuentro final con Abel Romero parece "más dueño de sí mismo" (153) que ninguno.

El proyecto de este vanguardista del mal transgrede todo límite porque él mismo encarna la violencia radical del ser humano al prójimo. La voluntad de unir arte y muerte es llevada al punto último con la intención de dar cuenta del instante único e irrepetible en el que dos extremos se tocan: la vida y la muerte. ${ }^{62}$ Wieder procura captar con sus fotografías en instante mismo en que las víctimas se mueren. Ese acontecimiento captado por la lente fotográfica y la experiencia que provoca en el espectador están signados por un horror que se intensifica con la presencia del artista en la obra. Sabemos que Wieder está detrás de cada escena (como lo está y se percibe detrás de cámara en las películas pornográficas). No se trata del artista que observa la foto de la muerte y a partir de allí estetiza el dolor, lo abyecto, ${ }^{63}$ sino que es su voluntad asesina trasformada en arte a partir de un plan que articula arte y muerte en la esfera de lo sagrado.

Las dos intervenciones artísticas de Carlos Wieder que se narran lo colocan en la escena vanguardista del arte en tiempos violentos. Importa tanto el gesto rupturista que pareciera encarnar como el escenario que lo enmarca, pero creemos que no se trata solo de la complicidad del artista con el poder sino de la utilidad del poder que hace el artista. Si bien es parte del aparato represivo de la dictadura parece más bien utilizar el contexto del terror para ejecutar su arte. Es ante todo un artista del terror y se erige por

\footnotetext{
${ }^{62}$ Muñoz Cano advierte que si bien las mujeres fotografiadas parecen maniquíes es probable que aún estuvieran vivas en el momento de hacerles la instantánea (97).

${ }^{63}$ Como la foto del torturado chino que Salvador Elizondo encuentra en el libro de Georges Bataille (Las lágrimas de Eros) y da origen a Farabeuf.
} 
lo tanto como contrario a la banalidad del mal. Wieder no es un mero engranaje de la burocracia dictatorial sino que se coloca como el poeta-sacerdote que cabalmente asume un proyecto macabro, el cual defiende ante todo riesgo. Es por ello que realiza los vuelos aún ante las inclemencias del tiempo y no le interesan los conflictos que puede provocar la muestra fotográfica ante los altos mandos militares -para quienes Wieder constituye un peligro: el de mostrar la cara oculta del régimen.

$\mathrm{Su}$ primera presentación en el mundo encorsetado del arte son los poemas escritos en el aire desde una avión piloteado por él mismo (es teniente de la Fuerza Aérea de Chile) y parece encajar perfectamente dentro del denominado retorno a las vanguardias de modo que cumple con el mandato de la superación de las limitaciones de la institución artística, por ejemplo, al disolver los marcos genéricos y ampliar los formatos establecidos de la poesía. La fusión entre estética y cotidianeidad también se actualiza en la ampliación de los canales de recepción de la obra. ${ }^{64}$ Ahora bien, su primera acción poética es presenciada por algunos presos (sólo uno reconoce y entiende el latín de los escritos en el aire: el loco Norberto que espera una nueva guerra mundial, otros creen que es publicidad de la iglesia) y es reconocida -pero incomprendida- por “soldados" y "caballeros" (20). El elitismo dado por la incapacidad del público para comprender la obra y la ruptura formal de la intervención artística resumen el acto vanguardista que parece estar matizado por el complejo vínculo con el poder que Wieder establece. Sus vuelos artísticos son disfrutados por "altos oficiales" y "hombres de negocios" en actos y conmemoraciones, alejándose de cualquier idea tradicional de vanguardia, ${ }^{65}$ legitimado por la crítica conservadora (el "anticuario y católico" (45) Nicasio Ibacache, a quien conoceremos en profundidad en Nocturno de Chile).

El contenido de sus escritos en el aire muchas veces parecería promulgar la violencia de su entorno de modo que la fusión arte y vida se transforma en arte y muerte

\footnotetext{
${ }^{64}$ El resumen de los rasgos neovanguardistas los enumera Nelly Richard (1994, 42-50) cuando describe las acciones que la "avanzada" realiza en el Chile dictatorial. No está de más recordar aquí las intervenciones de Rául Zurita en el desierto de Atacama (recordar a Willy Schürholz en La literatura nazi en América, discípulo de Ramírez Hoffman/Ruiz-Tagle/Wieder) o sus Escritos en el cielo. Al respecto ver (entre otros): Bolognese, Chiara (2010), "Roberto Bolaño y Raúl Zurita: referencias cruzadas" Anales de Literatura Chilena Año 11, Diciembre 2010, Número 14, 259-272. Si insistimos en localizar la novela de Bolaño también resuena la fotografía de Eugenio Dittborn ("Fosa común", 1997) que Richard lee desde un descentramiento de la foto a partir de la retórica militar y criminal: "detención", "captura", "prisión del encuadre" (Richard, 1994: 20); que Wieder llevará al extremo, literalmente. Ver el detenido análisis de Ina Jennerjahn (2002).

${ }^{65}$ Ana Longoni (2006) es quien relee la teoría de Peter Bürger como "encorsetamiento" a la vanguardia al limitar las aproximaciones concretas, específicas. Aquí Wieder encarnaría una vanguardia despojada de algunos de sus dogmas: como la idea de lo colectivo y el impulso de resistencia y ruptura con el poder (institucional -político, estético).
} 
ya que los nombres de mujeres que dibuja en el aire corresponden a las desaparecidas y asesinadas. Su proyecto, como retomaremos más adelante, encarna el discurso genesíaco que articula lo sagrado con la identidad del artista. La instauración de un nuevo orden, a partir del génesis bíblico revisitado, cuya figura central y superior es el artista que firma el texto impone la centralidad de la muerte -como limpieza- que no solo implica la muerte de mujeres sino de la poesía (son poetas asesinadas). La única voz que se distancia de la euforia que provoca Wieder es la del narrador quien resume la obra en el cielo con una palabra: incoherencia (91) y más tarde sentenciará que Wieder no es un poeta sino un criminal (126).

La última obra en público de Wieder ya no "representa" a las mujeres asesinadas, ahora las fotografía, es decir las "presenta" conforme a una voluntad artística de lo obsceno cuyo objetivo es exhibir la muerte. Las muertas de Wieder son las muertas del poder y todos callan y lavan culpas cuando encierran al crimen en los confines del arte y al mismo tiempo el servicio de Inteligencia rápidamente oculta el "arte" de Wieder en una caja. ${ }^{66}$

El proyecto de Wieder reviste un vínculo extremo entre el arte y el mal pues no se trata simplemente de reflejar lo real en las fotografías sino de hacer arte a partir del acontecimiento de la muerte. Esta pulsión artística que constituye la obra de Wieder se circunscribe al asesinato (hasta como Muñoz Cano puede inferir, en tiempo real: las mujeres son fotografiadas en el instante entre la tortura y la muerte) y nos lleva a ligar su "estética" con el género de las snuff movies ${ }^{67}$ al instalar la muerte como espectáculo en la exposición montada en el cuarto cerrado.

La compleja y huidiza figura de Wieder como artista del mal recoloca la sacralidad del arte ligado a lo trascendental en las fauces de la violencia. La relación de lo sagrado y la violencia que René Girard rastrea en las sociedades primitivas vuelve resignificada en el proyecto artístico de Wieder. La violencia sagrada refiere el crimen

\footnotetext{
${ }^{66}$ Wieder sigue la lógica contraria a Enriquito, asesino de Pizarro, ambos protagonistas del relato policial que Abel Romero cuenta al narrador. Enriquito intenta disipar las sospechas en su contra a partir de "revestir el crimen con los ropajes de la maravilla y de lo inverosímil" (123), volviéndolo ficción, interviniéndolo, montando un escena mientras que Wieder asume el riesgo de mostrar, de exhibir.

${ }^{67}$ Anna Topczewska (2012) analiza la articulación de las snuff movies con "La parte de los crímenes" en 2666. Seguimos con atención su artículo pues algunos de sus argumentos son aplicables a Estrella distante y porque nada es casual en el Hipertexo-Bolaño. Las fotografías de las mujeres muertas se erigen como precursoras de la sucesión de cadáveres de las mujeres asesinadas en Santa Teresa. Topczewska señala que especificidad de la snuff movie reside en la relación que establece con lo real antes que con lo macabro, que se da por sentado. Sin embargo, creemos que Estrella distante invierte esta idea porque Wieder no se plantea representar "lo real" (eso no tiene mayores complicaciones) sino su interés radica en presentar el instante mismo de la muerte que excede cualquier noción de lo real en tanto la realidad se detiene en el momento en que la lente dispara.
} 
originario que se instaura como origen de la comunidad (un nuevo orden anunciado en los vuelos que humean el Génesis, ligado a la muerte como limpieza y resurrección). El sacrificio desvía una violencia futura a partir de que la víctima asume en sí misma, en tanto ofrenda, el castigo colectivo. La extrapolación del análisis de Girard al contexto devastador de las dictaduras y totalitarismos donde (cual sociedad arcaica) no hay un sistema legal que desvíe la violencia (hacia el "chivo expiatorio") ${ }^{68}$ sino que la instaura, permite aproximarse a Wieder en su ambigua oscuridad. Al instituir su arte en el orden de lo sagrado configura la instancia sacrificial a partir de la violencia que coloca a la víctima en el lugar del chivo expiatorio. Wieder asume la función sacerdotal del poeta dado a fundar, a dar origen a un nuevo orden que es un arte nuevo a través del sacrificio (recordemos el ascetismo extraño con que se lo percibía en tiempos de los talleres literarios) de mujeres poetas. El giro a la sacralidad del mal de este artista de la violencia y asesino del poder no evita la violencia sino que la perpetra, la establece y, aún más, la escenifica: la vuelve espectáculo (Imbert 1992: 32). Si bien esta vanguardia del mal solo es viable en un contexto represivo y criminal (del que Wieder forma parte activa) la transgresión radical del poeta no es solo ligar arte y muerte sino anunciarlo. Hacer visible lo que debe permanecer oculto.

De este modo, Wieder articula una genealogía del terror y del nuevo orden que se remonta a las bases del cristianismo y que ha sido recuperada por los discursos mesiánicos de la izquierda y por los tópicos fundamentales de la derecha fascista. Hugo Vezzetti abarca estas cuestiones en un riguroso análisis donde refiere cómo estos sistemas ideológicos y de acción política proponen una regeneración basada en hacer tabla rasa con el pasado (2009: 176) y -desde los jacobinos- el terror se organiza como dispositivo instrumental. El afán que persigue Wieder de instaurar un orden nuevo, afín a la sensibilidad revolucionaria de la vanguardia, requiere una ruptura con el pasado que implica la aniquilación: la limpieza, la muerte (tal como anuncia en sus vuelos infernales)

La carrera de Wieder demuestra que el arte de vanguardia y la violencia estatal no están reñidos (86) y culmina así el abanico infernal que se abrió en La literatura nazi en América, al recorrer diversas semblanzas y estéticas que tienden puentes entre ideología y crimen. La radicalidad de Wieder estriba en la posición del artista respecto

\footnotetext{
68 "Es concebible que una víctima aparezca como responsable de las desdichas públicas y eso es lo que ocurre en los mitos, al igual que en las persecuciones colectivas, pero la diferencia reside en que exclusivamente en los mitos esa misma víctima devuelve el orden, lo simboliza e incluso lo encarna (Girard 1986: 60).
} 
del mal con el que se enfrenta, perpetra y anuncia. No importa tanto la calidad de la obra de Wieder como la fascinación y el terror que provoca en los demás, y la voluntad y el propio placer que experimenta sobre todo durante la exposición de fotos. ${ }^{69}$ Wieder se detiene en la estetización del mal transgrediendo el límite de la representación que se constituye en una opción válida al mismo tiempo que deja de serlo en la medida en que él mismo es el ejecutor del mal. Ya no hay poesía, sólo crimen (reiteramos, la mayoría de las mujeres aniquiladas son poetas) de modo que la estética del mal promulgada por Wieder hace sistema con el proyecto exterminador de la dictadura que, como asume la novela en tanto voz generacional, no sólo persiguió y destruyó a sindicatos, a movimientos políticos sino también a la poesía. Aquí se abre otra aproximación al mal anclada en los crímenes de la historia de los que Wieder es responsable y que la novela intenta recuperar desde la matriz genérica del policial sin por ello desplazar el núcleo oscuro del texto (Wieder y el mal) hacia una salida fácil de condena y denuncia contra los crímenes del Estado.

Ya hemos pautado cómo el personaje de Wieder no encaja en la figura de Hannah Arendt sobre la "banalidad del mal" porque los engranajes de la violencia estatal solo le sirven a su proyecto artístico que se constituye en sí mismo como maquinaria del mal. Tampoco se trata de la grandeza satánica ni de la tentación por sondar las zonas ocultas del ser sino que se muestra en su estado más extremo, en la frialdad consciente del crimen autorizado que sirve además para un proyecto artístico que fracasa, Wieder no es la estrella más brillante sino la que cae y debe invisibilizarse hasta desaparecer.

Sin embargo Wieder nunca pierde altura (si cae, es porque Romero y el escritor dan con él hacia el final). De ser el poeta más admirado pasa a ser el perseguido, pero no reniega de su voluntad artística y forma parte de un circuito alternativo del arte que si bien lo mitifica retoma ciertos tintes grotescos. Se trata de escritores del snuff arte, de grupos experimentales que articulan lo abyecto y la escritura, de revistas, editoriales y hasta de wargames. Algunos pueden ser Wieder, aunque tal vez no. Los comentarios del narrador se distancian de estos ejemplares del mal en tanto ya parecen clisés, como la obra de teatro del doble de Wieder, Octavio Pacheco, sobre los siameses que se flagelan mutuamente, la cual supone fácilmente todas las variantes de la crueldad y no es extraño que su tesis "peque de simple: sólo el dolor ata a la vida, sólo el dolor es capaz de

${ }^{69}$ A medida que el público sale de la habitación, Wieder sonríe "cada vez más satisfecho" (96). 
revelarla" (104), la simpleza descarada de esta tesis (casi una versión degradada de las ideas Georges Bataille, y de Sade) confronta los asesinatos impunes de las víctimas de Wieder. Asimismo la secta de los escritores bárbaros de la que Wieder sería miembro (con el seudónimo Jules Defoe) plantea la no-literatura a partir de un proceso de degradación del libro a través de vejaciones escatológicas contra el objeto libro con el fin de asimilar su sabiduría por la experiencia corporal con el mismo. Si bien parece adherir al principio vanguardista de ruptura (con "la cultura, la academia y la técnica", 140) el proyecto deviene poco serio (se los describe como "pandilla", publican en una "Revista de los vigilantes nocturnos de Arras") y diferente del prontuario de Wieder: los franceses bregan por la destrucción -material- de la poesía, mientras que el poeta chileno promulga la instauración de un nuevo orden. ${ }^{70}$

Es interesante salir de la novela para conectar estos hilos del mal con el ensayo que Bolaño escribe sobre Interferencia secreta ("Palabras del espacio exterior", Entre paréntesis) porque allí ancla el mal en una estética de lo extremo (que de tan real se vuelve siniestra) como las fotografías donde Wieder pretende captar el instante de la muerte. Se trata de un documento sonoro -y fílmico- que recupera los audios militares del 11 de septiembre de 1973 en momentos previos al ataque a La Moneda, durante el bombardeo, el último discurso de Salvador Allende y demás grabaciones atroces. Como señala Bolaño, estas voces vienen del pasado y son familiares, son las voces de la infancia (80), son voces de hombres reales y por fin tienen su papel: actúan pornografía, una snuff movie, "un diálogo en el otro lado de la realidad, allí donde el diálogo es imposible" (80). Es así como la novela también muestra una demanda de justicia muy compleja.

Esta zona gris se configura desde los códigos del policial y cobra importancia con la figura de Abel Romero, el detective que busca a Wieder, quien se coloca como el artífice de la justicia (que no se concreta en el plano adecuado de los juicios por crímenes de lesa humanidad) pero es también un asesino a sueldo (él tiene el encargo de encontrar a Wieder).

De modo que el hecho de que todos estos sujetos que arman la novela (Belano, Bibiano, "Bolaño") sean poetas, escritores, no es un dato menor. La matriz del género policial que emerge en el relato es otro modo corrosivo de la función del testimonio

\footnotetext{
${ }^{70} \mathrm{El}$ narrador mismo se plantea la ridiculez y lo incomprensible del proyecto de Raoul Delorme: “ipero cómo se le pudo ocurrir a ese hombre que profanando libros se podía mejorar el francés hablado y escrito?" (142)
} 
como documento que analizamos al principio. Esto produce un distanciamiento aún mayor respecto de los sucesos artísticos y criminales que la historia quiere reconstruir pues caen de lleno en el territorio de la ficción desde un modo altamente codificado como el policial. Por supuesto, el texto nunca cristaliza en un bloque genérico pero es interesante notar cómo desde allí juega con la cuestión de las fuentes, los documentos y los testimonios para poder dar cuenta del crimen, a partir del seguimiento de ciertas pistas (literarias todas) para dar con el criminal. Así como hay una profusión de figuras autorales, abundan las fuentes cuya acumulación hace estallar su valor documental, como si en verdad la historia de Wieder se negara a ser reproducida para sólo atisbarse en su construcción. Es decir, las pistas que pueden recolectarse no logran dar con Wieder, sólo con la ayuda del escritor -es decir, a través del uso de la ficción- puede encontrarse al artista asesino. Bibiano, Abel Romero y el narrador recorren el camino de la literatura para entrar en la vida de Wieder -e incluso también a su muerte, pues el objetivo es liquidarlo- y así es como dan con el paradero del poeta asesino: a través de la lectura. Es un seguimiento literario el que realizan para finalmente llegar a la muerte. $^{71}$

Hay instancias que, dentro de la lógica reparadora del relato policial, inscriben una idea de justicia. El recuerdo del narrador se intercala con la información de las cartas de Bibiano que le llegan a Barcelona, desde donde se narra. A partir de los años noventa, los datos sobre Ruiz-Tagle/Wieder llegan de las actas judiciales y declaraciones de testigos en el marco de juicios contra crímenes de la dictadura que se disuelven en el olvido. La escena de la exposición de fotografías es reproducida a partir del libro de Muñoz Cano, un teniente retirado que a modo de acto exculpatorio publica su autobiografía, Con la soga al cuello, quién mejor para relatar la hipócrita reacción ante las macabras fotografías: "silencio incómodo" (99), "sin que sucediera nada, ante el mutismo" (100), "duerman un poco y olviden todo" (101). Esta parte del relato se nutre de los testimonios de Muñoz Cano y da cuenta de la complicidad y el silencio, de modo que es significativo que el narrador abandone la primera persona para dar cuenta de otra dimensión del arte de Carlos Wieder que desnuda la connivencia del crimen con la cultura, el silencio del establishment y sus poses (que además tienen su correlato en las investigaciones periodísticas y judiciales que se abren con la democracia y decantan en el olvido). Bibiano asume el rol de detective tras las pistas de Wieder pero ni él -ni la

\footnotetext{
${ }^{71}$ Confirmamos la muerte de Wieder en la entrada de su biografía en La literatura nazi en América: "Santiago de Chile, 1950- Lloret de Mar, España, 1998".
} 
justicia- pueden dar con él. El continuador de la tarea de Bibiano es un ex policía en tiempos de Allende, Abel Romero, quien decide aunar fuerzas con el narrador y localizar a Wieder a través de la literatura: y es desde la literatura que acceden a la encarnación del mal: Alberto Ruiz-Tagle, Carlos Wieder, Octavio Pacheco, Jules Defoe; es decir, puede ser todos o ninguno.

Sin embargo, también a medio camino entre el intento de comprender el mal y la imposibilidad de hacerlo, en modo alguno se plantea una dicotomía cerrada y el mismo narrador lo reconoce: "Wieder y yo habíamos viajado en el mismo barco, sólo que él había contribuido a hundirlo y yo había hecho poco o nada para evitarlo" (131). Además, a pesar de colaborar con Romero, el narrador expresa su disconformidad con el desenlace que Abel ha venido a ejecutar. ${ }^{72}$

La escena casi al final de la novela, en el momento clave del reconocimiento del criminal, el narrador "Bolaño" se ve atrapado por dos miradas opuestas: los ojos de Wieder, apagados, lo escrutaban desde una mesa cercana del bar en que se encuentran. Mientras que las palabras del libro de Bruno Schulz que el narrador intenta leer adquieren una dimensión monstruosa (152) y se convierten en los ojos del escritor judío asesinado por los nazis, "unos ojos claros como el cielo, brillantes como el lomo del mar" (152). Estos ojos brillantes imaginados por "Bolaño" que parpadeaban desesperadamente contrastan con la impavidez oscura de Wieder, que se mantiene férreo hasta el final. Una vez finalizado el trabajo, ${ }^{73}$ la percepción sobre Abel Romero también hace foco en la mirada, sus ojos son los mismos que antes, son “ojos que saben. Ojos que creen en todas las posibilidades pero al mismo tiempo saben que nada tiene remedio" (156). Nada ha sido enmendado y la alusión al actor Edward G. Robinson (con quien se lo compara a Romero), después de haber pasado por una máquina de moler carne, ${ }^{74}$ completa el cuadro: entre los ojos duros de victimario de Wieder $^{75}$ y la

\footnotetext{
72 Abel Romero forma parte, junto con otros infames, del "Epílogo de monstruos" que cierra La literatura nazi en América, junto con un tal Juan Cherniakovski, "guerrillero panamericano" (205). El crimen de Romero tiene que ver la justicia y también con la venganza, lo que pareciera explicar su inclusión en el epílogo, mientras que podemos aventurar el porqué de la misma suerte del sobrino del general soviético. La pauta está en Estrella distante al evocar la figura ya clásica de la traición de la izquierda latinoamericana: "los hijos de puta que mataron a Roque Dalton mientras dormía para cerrar la discusión y porque así convenía a su revolución” (69). Pero no se trata de equiparar crímenes sino de abismarse en su sin sentido, de visibilizarlos con la mirada microscópica de la literatura que todo lo desestabiliza.

${ }^{73}$ El narrador se espanta al reconocerlo: "Estamos trabajando, pensé con horror" (154).

${ }^{74}$ En la última película de Robinson (1893-1973), Soylent Green (1973) un clásico de la ciencia ficción de Richard Fleischer, los neoyorquinos en el año 2022 se alimentan de un producto fabricado a base de carne humana triturada. La versión en español del título también pareciera apuntar a un guiño de Bolaño: Cuando el destino nos alcance. Acorde con los textos de Bolaño esquivos a la fijación de sentidos, es
} 
mirada insoportable de víctima de Schulz están los ojos de Romero que se saben partícipes de la máquina de la muerte humana. A diferencia del narrador, a Romero no le tiembla el pulso de la ética pues como bien señala Manzi (2004: 139) él no ve el rostro humano del monstruo. ${ }^{76}$

El final abierto que deja esta compleja aproximación al mal absoluto vacila entre dos posibilidades. Una, involucra a la justicia por mano propia en donde la colaboración del escritor es clave y que se ejercita bajo la ausencia estatal de acciones reparadoras frente a la violencia dictatorial. Otra, asume la crítica a la venganza individual a través de la resistencia que el narrador atisba frente al acto final. En esta dualidad del personaje "Bolaño" tensada entre su colaboración con Abel y su rechazo a la muerte del criminal se articula una compleja postura respecto de la justicia y los modos de ejercerla. $^{77}$

válido también el intertexto propuesto por Joaquín Manzi (2004), quien lee en Romero a Wilson, el cazador de nazis en la película The Stranger (1946) de Orson Welles.

${ }^{75}$ No olvidemos la metonimia: el ojo de la cámara fotográfica con la que Wieder dispara a las mujeres torturadas.

${ }^{76}$ Recordemos la aparición de Abel Romero en uno de los testimonios de Los detectives salvajes, donde espantado por el clisé de hablar "sobre el ala negra del mal" en relación a la dictadura militar, afirma que es posible derrotar al mal si éste es causal y no casual (397). Romero tiene el pragmatismo del detective de la serie negra y sigue una lógica más cerrada que el narrador de Estrella distante (causa: crimen/ consecuencia: justicia como sea). Contraria también a la postura de Graham Greenwood (el estudioso de la Philip K. Dick Society) que 1 ecuenta a Bibiano su teología del infierno, "un entramado o una cadena de casualidades" (110).

${ }^{77}$ Esta cuestión volverá a aparecer en $E l$ Tercer Reich, como veremos. También regresa dimensionada de un modo completamente distinto en 2666 en la historia de Hans Reiter y Leo Sammer (aquí sí aparece la banalidad del mal, en el nazismo precisamente). 


\section{3. Bolaño est un autre: historias mínimas, grandes cuentos}

En los dos textos analizados anteriormente las vidas de escritores arman diferentes modos de aproximarse al mal y a la violencia desde el perfil del escritor y desde las opciones estéticas que promueven. De esta manera se reflexiona sobre diferentes cuestiones propias del oficio como la autonomía del arte o las relaciones con el poder político, las zonas menos visibles de la tradición y las conexiones del mal extremo con la literatura desde un prisma de refracción anclado en América Latina. Asimismo, la ficcionalización del autor Roberto Bolaño produce una autofiguración (autoficción) ${ }^{78}$ que si bien se manifiesta contra una referencialidad estable permite hilar cierta coherencia para "configurar una unidad imaginaria de la vida" (Arfuch 254) que construye una identidad de escritor junto a su escritura y dentro de ella. Como señala Premat, la autoficción se mueve entre los intersticios del yo biográfico (social) y el proceso de escritura (textual). ${ }^{79}$ La autoficción, entonces, condensa el cruce de lo ficcional con lo real a partir del desplazamiento del pacto de identificación entre autor y narrador que sella la autobiografía. El nombre propio ("Bolaño", "Belano, "B”) arma un nuevo pacto de lectura que permite las entradas y salidas a la biografía de Bolaño, a la ficción y al relato que, en este umbral, construye sobre sí mismo.

Los rasgos y motivos (que a veces se integran al nombre "Bolaño" o a heterónimos como Arturo B., Belano) que van a ir tramando esta autofiguración tienen una fuerte presencia en los cuentos con los que trabajaremos en esta sección. Las derivas del nombre propio será uno de los elementos que integren los cuatro volúmenes que analizaremos a continuación: Llamadas telefónicas, Putas asesinas, El gaucho insufrible y El secreto del mal.

Acorde con la arquitectura general de la narrativa de Roberto Bolaño, los cuentos pueden leerse -desde su especificidad formal- como "textos integrados". Partiendo de los aportes de la crítica anglosajona, Pablo Brescia y Evelia Romano (2006) han propuesto leer al cuento en la tradición literaria latinoamericana a partir de

\footnotetext{
${ }^{78}$ Utilizamos ambos conceptos como complementarios, siguiendo a Julio Premat: "las ficciones de autor, en tanto relato, y las figuras de autor, en tanto que imagen" (2009: 12).

79 “...la identidad del escritor es inestable, desplegar esa inestabilidad bajo modos ficticios es, entonces, una modalidad de afirmar procesos identitarios. Por lo tanto, ver en él una ficción implica leerlo a partir de la ambivalencia (...) polisémico, a medias entre lo biográfico y lo imaginado, a la vez fantasmático y socialmente determinado..." (Premat 28)
} 
“ciertos patrones de relación” (7) que diseñan una unidad integrada y presentan una particular visión de mundo. ${ }^{80} \mathrm{El}$ análisis que el crítico británico Forrest Ingram publica en 1971 sobre los "ciclos cuentísticos" aquellos cuentos cuyos vínculos inciden en la experiencia de lectura y tensionan la relación entre unidad y conjunto. ${ }^{82}$ Enrique Anderson Imbert (1979) ya aportaba la versión latinoamericana a los ciclos cuentísticos de Ingram al referirse y clasificar los “cuentos agrupados" según enlaces propuestos por el autor (o el editor) y reconocidos por "el buen lector". La recurrencia de motivos, temas, tipos de narrador, personajes y espacios entre un cuento y otro conforman una idea de unidad que en Bolaño no se circunscribirá a los cuentos reunidos en un mismo volumen sino que se abrirá a otros libros (cuentos y novelas). Como en todo el Hipertexto-Bolaño, los cuentos están atravesados por entradas y salidas entre ellos, o puentes hacia o desde las novelas, configurándose en "textos integrados" que proponen otras incursiones en la cartografía literaria de América latina de los últimos años. El juego constante entre unidad y diferencia interpela al lector que va conectando las piezas de este modelo para armar. Sabemos, por ejemplo, una vez leída Estrella distante que el detective con el que dialoga Joanna Silvestri en el cuento homónimo de Llamadas telefónicas es Abel Romero y el fantasma que está buscando es Carlos Wieder. Se completan así ambos textos, el cuento se integra a la historia de la búsqueda del poeta asesino expandiendo la única mención de Silvestri en una página de la novela (134). Los "textos integrados" de Bolaño operan en tres dimensiones. La primera, al interior de cada contario cuyos relatos tienen una lógica interna y a su vez proponen modos de integración entre ellos lo que permite leerlos como una totalidad relativamente orgánica. Un segundo nivel radica en los vínculos entre los contarios a partir de ciertos dispositivos que los articulan. Y por último, la integración tiene que ver con todo el Hipertexto-Bolaño, el libro de arena.

Ahora bien, para pensar los cuentos de Bolaño atendiendo a la especificidad de las formas breves es necesario actualizar listar las reformulaciones del cuento moderno que los mismos escritores han manifestado desde Edgar Allan Poe. En "Filosofía de la composición" Poe desglosa todo el proceso de composición del poema "El cuervo" y

\footnotetext{
${ }^{80}$ Ver en el volumen coordinados por ellos el artículo de Gabriela Mora (53-76) quien sistematiza una aproximación teórica con variados ejemplos latinoamericanos.

${ }^{81}$ Representative Short Story Cycles of the Twentieth Century: Studies in a Literary Genre (The Hague: Mouton, 1971). Aquí Ingram le da estatuto genérico a lo que él llama ciclos cuentísticos y analiza los cuentos de Franz Kafka, William Faulkner y Sherwood Anderson.

82 "Cada ciclo cuentístico muestra un doble tendencia que, por un lado, afirma la individualidad de sus componentes y, por el otro, resalta los vínculos de la unidad que conforma lo múltiple en un todo único" (19, traducción nuestra).
} 
sus reflexiones se hacen extensivas a los modos de construir el relato breve. Siguiendo una lógica rigurosa, el escritor debe tener como horizonte el efecto que el texto causará en el lector de modo que el final es la parte fundamental de su arquitectura. Esto se suspende en el relato moderno que transforma el final epifánico del relato clásico en un final abierto (Zavala 2009). Desde la teoría de Ricardo Piglia, los cuentos narran dos historias, una permanece oculta y surge al final del texto. Mientras que en el cuento moderno, la historia oculta nunca es revelada.

Para entender la apropiación que Bolaño realiza de las teorías del cuento basta con sumergirse en los relatos y atender a su permeabilidad a diferentes matrices genéricas o a los distintos guiños intertextuales que permiten delinear sus contornos. De hecho, en "Consejos sobre el arte de escribir cuentos" (Bolaño 2004: 324) él mismo privilegia la lectura en la parodia a los mandamientos que listan las reglas de la composición del cuento. Fiel a la tradición inaugurada por Edgar Allan Poe en torno a las preceptivas de la narración breve, que siguieron Horacio Quiroga (en su "Decálogo del perfecto cuentista”) o Augusto Monterroso (más cerca de Bolaño), las doce sugerencias bolañanas se concentran sobre todo en ofrecer lecturas antes que en aconsejar sobre cómo escribir. Contra la indicación del título, no hay sugerencias sino que el tono manifiesta la forma del mandato: "hay que leer...”. Aquí, se evidencia la ironía en el privilegio, a partir del imperativo, que se otorga al buen lector (borgeano) antes que a la descripción de alguna técnica o fórmula mágica. Comparte con Monterroso, además del tono burlón, el no abstenerse ante la apabullante necesidad de escribirlo todo, en cantidades generosas. ${ }^{83}$ Pero así como el guatemalteco aconseja no perder de vista al lector, Bolaño prefiere ser el mejor lector de todos como si con eso bastara.

A grandes rasgos, los cuentos de Bolaño, además de insistir en Poe (hay que pensarlo de rodillas, exhorta), mantienen la intensidad y el efecto que Poe defendía pero los va diluyendo en la trama de modo que cuando el lector se acerca al final choca con el vacío. La tesis de las dos historias que Ricardo Piglia sistematiza y tiene como epígono a Jorge Luis Borges se actualiza en Bolaño no sólo en los cuentos sino en toda su narrativa a partir del trabajo particular con diferentes matrices genéricas que Bolaño realiza (como veremos con atención en el capítulo 5, sobre el policial). Muchas veces el escritor chileno acata la premisa del cuento que se construye sobre dos historias y una

\footnotetext{
${ }^{83}$ Monterroso: "Cuando tengas algo que decir, dilo; cuando no, también. Escribe siempre." Bolaño: "Si se ve con energía suficiente escríbalos de nueve en nueve o de quince en quince"
} 
de ellas permanece oculta hasta el final. Mas el giro desestabilizador aparece cuando lo oculto permanece secreto, cuando la decepción sobreviene ante el vacío etéreo de la resolución. No hay un final que establezca un sentido único ni último, el relato se funda en un movimiento continuo, en desplazamientos que cortan, expanden y actualizan el problema base de nombrar lo innombrable. Los momentos de ruptura (los finales) de vacío interpretativo surgen ante la imposibilidad de poner en palabras, de descifrar, lo vivido y lo recordado.

\section{Llamadas telefónicas, de la postutopía al mercado: sobrevivientes en la intemperie}

Así sucede en los cuentos de Llamadas telefónicas, el primer volumen de cuentos de Roberto Bolaño publicado por Anagrama (1997), donde aparecen personajes, muchos de ellos escritores, que carecen de puntos de anclaje, que son sobrevivientes y están desamparados. Conforman el volumen catorce relatos agrupados en tres partes ("Llamadas telefónicas", "Detectives", "Vida de Anne Moore") cuyas historias se relacionan a través de constantes que permiten leerlo como un "texto integrado". El narrador en primera persona es una de las instancias que conecta esos relatos, si bien no todos los cuentos comparten la misma voz narrativa cada vez que aparece se presenta como igual: es escritor y es chileno, vive en España, con casi nada de dinero. A veces se identifica como Belano, ese doble que desde la autoficción ya puede indetificarse como "Bolaño", es una subjetividad organizadora que otorga cierta coherencia aunque no fija sentidos -el sentido a veces se escapa, se filtra en los modos de armar el relato- pero trama una red de significaciones que entrecruzan los cuentos de las diferentes secciones. Además, es una figura que narra desde el recuerdo y lo recordado tiene un contexto específico: las dictaduras militares que se inician en los años setenta en el Cono Sur. Los cuentos que organiza son "Sensini", "Enrique Martin”, "El gusano", "Detectives" y “Compañeros de celda". En otros no se explicita la identidad del narrador, el nombre propio, pero podemos inferir que son historias que Belano ha recopilado y vuelve a contar, como "La nieve" (un chileno se la relata al narrador chileno) u "Otro cuento ruso" donde descubrimos que Amalfitano, el profesor chileno exiliado en Barcelona que luego acabará en Santa Teresa, es la fuente del relato.

Podemos intuir entonces que Belano es quien narra todas las historias que él mismo vivió, y otras que reproduce según tal como se las han contado. A veces el marco es explícito como en "Otro cuento ruso" (Segunda Guerra), otras el narrador 
“desaparece" y es mero personaje como en "Detectives" (se prioriza el diálogo, Belano es un personaje) o también puede ser quien transcribe como en "Joanna Silvestri" donde quien relata es la misma actriz porno.

Hay por debajo otra matriz que otorga coherencia a las historias entre sí: la coyuntura histórica de los setenta y sus consecuencias, que aparecen tematizadas aunque nunca explícita o directamente, que Belano ha padecido. Uno de los ámbitos desde los que se explora esta problemática es por supuesto la literatura, o más específicamente, el lugar del escritor. Esta figuración narrativa del yo permite delinear diferentes imágenes de escritor que conviven en Llamadas telefónicas y desde la categoría de autoficción podemos pensar cómo Bolaño reflexiona sobre los avatares del escritor desde un lugar que hace estallar toda noción de campo literario.

La categoría "imagen de escritor" ya mencionada (Gramuglio 1992) ofrece diversos puntos de análisis que permiten abordar los cuentos a partir de lo que María Teresa Gramuglio denomina un "lugar en la literatura" y un "lugar en la sociedad", esto es la relación que se establece con la tradición literaria, los lectores, las instituciones, el poder o el mercado, instancias que Bolaño dispersa en algunos de sus relatos, como veremos, para repensar la idea misma de campo literario en tiempos crepusculares.

Esa falta de resolución, la incertidumbre y el vacío que anunciamos como rasgos de algunos cuentos pueden leerse como respuestas literarias a las tramas sociales y políticas, como modos específicos de articularse con la coyuntura de enunciación latinoamericana. Si seguimos los postulados de Beatriz Sarlo (1987), el ya definido por la crítica "corpus de la literatura de la dictadura y del exilio", aunque heterogéneo, está unificado por cuestiones que abarcan desde lo temático a la elección de una estética. Así, como señala Sarlo, la relación posible que los textos presentan con sus contextos político-sociales se da a través de una oposición discursiva: la configuración de un discurso literario formalmente opuesto al discurso de la dictadura. Sarlo define al discurso autoritario de la dictadura como un monólogo para fijar sentidos que impone una verdad única, una sola interpretación; que determina identidades caracterizadas en términos de inclusión y exclusión (buenos y malos). Frente a esa homogenización, el discurso literario presenta una pluralidad de sentidos abiertos, en el marco de la crisis de la representación realista y de la hegemonía de estéticas preocupadas por problemas de construcción (Sarlo, 1987: 41). Otra manera de caracterizar la literatura de la dictadura, además de la relación entre escritura y hecho político- social, es por su contenido. Temas recurrentes como la censura, (auto) represión o tortura apuntan a la tematización 
de acontecimientos políticos y las experiencias sufridas por los sujetos. O son textos que recrean la experiencia del exilio a través de los desplazamientos de las personas y los de las escritura.

Ahora bien, Roberto Bolaño se inscribe en esta generación que sufrió la violencia de las dictaduras y del exilio; comienza a publicar en editoriales reconocidas en los años noventa, aunque varios de sus textos daten de finales de los setenta y principios de los ochenta. Sin embargo, encasillarlo dentro de un "corpus de la dictadura y del exilio" limitaría su potencial estético y crítico. Como exploramos a lo largo de este trabajo, en Bolaño hay una negación del discurso testimonial canónico aun cuando la literatura y la vida parecen invadirse mutuamente. Y si los datos biográficos del propio autor atraviesan la mayoría de las historias ya hemos visto que forman parte del juego autoficcional que le permite correrse de los lugares comunes, de las páginas fosilizadas de los relatos de la memoria latinoamericana. Llamadas telefónicas enuncia la violencia, las herencias y los sinsentidos de las dictaduras y los regímenes totalitarios pero sobre todo reflexiona sobre el arte de escribir, las posibilidades del escritor a contramano, en el abismo, una obsesión recurrente en el Hipertexto-Bolaño.

A través del principio del desplazamiento lo político se manifiesta desde la narratividad del cuento, casi nunca es material representado directamente. Como ya advertimos, no existe la posibilidad de una lectura que ponga en primer plano lo ideológico. Tiempo y espacio también se desplazan y se espejean: Buenos Aires durante la dictadura, España y el franquismo, Francia o Rusia en la Segunda Guerra, el exilio en España a finales de los setenta y principios de los ochenta, Rusia en los primeros setenta. Son historias mínimas recordadas o escuchadas en un bar de vidas vertiginosas, de mujeres-fantasma, de hombres solitarios. Tal vez porque la única función que le cabe a la literatura es contar el vacío, escenificar la ausencia de ideas rectoras, ante la imposibilidad de reconstruir marcos de referencia. Estos personajes viven continuos desplazamientos en el espacio o viven un exilio devastador, los escritores son malos, enloquecen, se suicidan o sobreviven al margen. Frente a estos sujetos, la subjetividad del narrador se construye también a partir de los rasgos del otro, en relación especular con la alteridad que permite pensar esas vivencias desgarradas como constitutivas del yo que narra. El narrador es personaje de su propia generación, es un escritor en el exilio y desde allí reflexiona sobre la literatura.

La primera sección, "Llamadas telefónicas" (del volumen homónimo), reflexiona exclusivamente sobre la práctica de la literatura en el marco de determinadas 
circunstancias históricas, ficcionaliza imágenes y contra imágenes de escritor (tipologías o arquetipos como el comprometido, el militante, el exiliado, el marginal, el fracasado, el vanguardista), construye y ejemplifica poéticas. Al considerar la literatura como práctica institucional el sujeto autor también traza relaciones fuera del campo cultural, y la relación que une a la sociedad con la literatura se explicita cuando determinado momento histórico influye en la construcción de una figura de escritor que permite poner en escena los diversos debates que atraviesan un campo literario. ¿Qué figuras trashumarán por la literatura sin campo? La teoría de Pierre Bourdieu (1992) que organiza la práctica literaria a partir de un campo de luchas, de posiciones específicas y relativamente autónomas respecto del poder, por ejemplo, muestra sus fisuras ante la violencia que socava toda posibilidad de articulación. El desmembramiento generacional que se tematiza en varias de las obras (no sólo en los cuentos) da cuenta de lo que antes pudo ser un campo literario y del que ya solo quedan retazos.

En esta primera parte la pregunta matriz incluye al escritor comprometido y revolucionario que a la luz de la Revolución Cubana participa del entusiasmo latinoamericano y luego ha sufrido los embates de las dictaduras del Cono Sur. Se pregunta por el lugar del escritor en el escenario de la postutopía y la derrota latinoamericana y en este sentido reescribe al escritor fracasado de Roberto Arlt. Las diferentes figuras diseñadas en esta primera sección comparten la constante de ser escritores marginales y malos escritores (como su directo precursor arltiano, que Juan Carlos Onetti también retoma en las figuras de los perdedores). Bolaño recoloca al escritor fracasado de Arlt y al perdedor de Onetti en el espacio de la posdictadura, en ese desierto que adviene cuando las utopías fueron arrasadas y quien sobrevive se configura entonces como "el escritor derrotado" y "el escritor melancólico". La visión crítica que se conjuga con el homenaje a esa generación de escritores heridos adquiere diferentes tonos entre la melancolía y la burla. Porque el humor permite la distancia y evita la beatificación propia de los discursos totalizadores.

En "Sensini", que abre el volumen y constituye el relato matriz, el narrador en primera persona (sin trabajo, escritor amateur, chileno, exiliado y "más pobre que una rata", 13) describe la relación con otro escritor, argentino. Ambos participan de concursos literarios para intentar subsistir. Es en uno de ellos que el narrador obtiene el tercer lugar y Luis Antonio Sensini, el segundo. Su cuento reveladoramente versa sobre un campo plano, yermo (14) donde va el protagonista tras la muerte de su hijo, un cuento claustrofóbico que entusiasma a nuestro narrador y decide buscar a Sensini. 
Ambos sobreviven de los concursos literarios de provincias españolas, de poca monta pero Sensini tiene una historia literaria: varias obras publicadas y, sobre todo posee un linaje (que incluye hasta un escritor faro: Roberto Arlt): pertenece a esa generación intermedia de la que ya quedaba poco, cuenta el narrador, "pero no por falta de brillantez o talento" (15), y por si quedan dudas recuerda al exponente más conocido, Haroldo Conti, "desaparecido en uno de los campos especiales de la dictadura de Videla y sus secuaces" (15, énfasis nuestro). La marginalidad del escritor fracasado de Arlt que no encuentra el modo de ingresar al campo literario aquí se desplaza a la dictadura y al exilio que destruyen la noción misma de campo de modo que el escritor no puede anclar en ningún sistema de pertenencias.

En esta vida exiliada, marcada por la dictadura (Sensini tiene un hijo desaparecido, cuya sombra deambula a lo largo de todo el relato) el escritor está caracterizado por la no pertenencia, también exiliado de un campo literario fragmentado, o mejor dicho disuelto por la coyuntura histórica. Ahora le queda el recuerdo de un único éxito editorial y sus libros se venden como saldos, en puestos callejeros y ambulantes. El narrador ubica a Sensini dentro del linaje literario del escritor militante, no simplemente comprometido, cuyas figuras paradigmáticas son Rodolfo Walsh y Haroldo Conti, figuras arrasadas por la violencia dictatorial, que si no están muertos, están en el exilio corrigiendo traducciones, escribiendo cuentos que salen “a pelear en provincias" (21). La simpatía del narrador por Sensini permite pensar una cierta ambigüedad respecto de las posibilidades del escritor en el exilio y luego en democracia recuperada como si a Sensini no le quedara otra: concursar y añorar lo perdido. Hay un eco de homenaje hacia esos escritores que se entregaron a una causa y hacia los que, sobreviviendo, luchan por una literatura en un espacio fracturado. ${ }^{84}$

Se trata de una figura de escritor que ha sobrevivido a la lucha de la izquierda revolucionaria y sobre todo a la dictadura. Esto es, no ha tenido la muerte en algún punto heroica como fueron los destinos de Walsh y de Conti -ni la muerte en combate, ni la desaparición- que los colocan en el espacio del caído, de víctima del terrorismo sino que la figura del sobreviviente está marcada precisamente por la carencia de un espacio cobijador. Nuevamente Bolaño se corre de un relato que cristalice el pasado revolucionario en el lugar del heroísmo idílico al recuperar esta figura del sobreviviente

\footnotetext{
${ }^{84}$ Existe un consenso por parte de la crítica en identificar la figura de Sensini con el escritor Antonio Di Benedetto, un tributo de Bolaño hacia el escritor argentino muerto unos años después de regresar del exilio.
} 
completamente alejada del transitado tema del "traidor y del héroe" basado en la sospecha que el discurso militante imprime en la figura de quien no murió la "muerte bella" del revolucionario (Vezzetti 2009).

En esa aridez de un campo literario que agoniza se expone también una suerte de reconciliación entre dos instancias de legitimación en apariencia antagónicas, pero que en cierta medida aparecen como externas a lo literario: el mercado y la academia. Aquí también se tergiversan los postulados canónicos de la literatura con mayúsculas desde un escenario mutilado. En primer lugar, el mercado está caricaturizado pues se reduce a esos concursos que ni siquiera aparecen en las páginas culturales, los lectores son entidades patrocinadoras, como el ayuntamiento, las cajas de ahorro, o los jurados que no leen las obras presentadas o lo hacen a medias. En segundo lugar, el reconocimiento por parte de escritores con fuerte capital simbólico aparece tímidamente -pero reivindicado solo porque proviene de "simples pares compatriotas" -en las cartas que según menciona escribió Jorge Luis Borges y en los comentarios de Julio Cortázar y Manuel Mujica Láinez. Se reivindica el oficio de escritor no así la idea de mercancía que supone cierta lógica del campo literario pero que aquí no funciona: el narrador no participa más que de un concurso y Sensini exagera al enviar el mismo cuento con diferentes títulos a varios certámenes, como si esta posición marginal de Sensini fuera consecuencia directa de los acontecimientos históricos (la dictadura) que imposibilitan la acción y el sentido. Sensini escribe un mismo cuento al que titula de cuatro maneras diferentes: "Al amanecer", "Los gauchos", "En la otra pampa" y "Sin remordimientos". $\mathrm{Al}$ querer recuperar un posible sintagma a partir de los títulos se hace visible la falta del verbo. No hay acción, y los títulos construyen una especie de red semántica que, como respuesta literaria, connota la situación represiva del Cono Sur: la idea de un espacio limitado (el horizonte al amanecer), la frontera y el destierro (la figura del gaucho), el exilio, el otro lugar (la otra pampa) y la aceptación, sin remordimientos casi obligada a causa de ese exilio geográfico y literario. La metáfora del campo herido (el campo intelectual arrasado) se completa con otro cuento de Sensini quien lo titula de las siguientes tres maneras: "Los sables", "Dos espadas" y "El tajo más profundo". Las imágenes apuntan explícitamente al corte, la herida, a las armas filosas que cercenan. Cuando Sensini regresa a Buenos Aires no le permiten el retomar la universidad y sólo se interesa por la búsqueda imposible de su hijo, Gregorio, del cadáver de su hijo desaparecido que nunca encontrará. 
¿Qué función le cabe a la literatura en esa coyuntura, qué le resta al escritor sino contar el vacío de una generación que no tiene revancha? La generación posterior no puede superar ese legado: Miranda la hija de Sensini comienza a vivir esa vida sin rumbo, la vida de Clara (en el cuento homónimo), de Sofía (en “Compañeros de celda"), de las mujeres-fantasma que Bolaño describe como arquetipos de una condición generacional. ¿Cuál es el lugar del exiliado? ¿A qué campo literario pertenece si ya no le quedan pares a Sensini? Los relatos que siguen son variantes de Sensini y condensan los tópicos de la desolación, el abandono o el no lugar.

"Henri Simon Leprince" expone una imagen de escritor no tan amable como la del cuento anterior. Aquí se ponen en tela de juicio ciertas estrategias de legitimación ya convencionalizadas en un marco también opresivo, el del nazismo en Europa. Leprince es el escritor fracasado que sobrevive como periodista y publica en revistas de provincias. Al igual que Sensini, permanece al margen de los circuitos intelectuales consagrados pero Leprince es indudablemente un pésimo escritor que ingresará a esos circuitos desde lo político, sin saber bien porqué, nunca por su trabajo como escritor o cualidades literarias (nunca por cuestiones específicas del campo literario, otra vez se desborda el esquema de Bourdieu). Lo que se problematiza aquí es la cuestión del escritor comprometido, no del militante; la figura que se reivindica en el relato anterior es la del intelectual militante de izquierda que sirve a la revolución, pero escritores como Walsh forman parte de un pasado doloroso, de una tradición que Sensini continua en calidad de sobreviviente desde un presente también doloroso. En cambio, la militancia de Leprince es casi azarosa, y su participación en la política lo ayuda a contactarse con el mundo literario, y sin embargo "nadie se toma la molestia de saber qué escribe el escritor que les ha salvado la vida" (33).

Leprince entra al círculo de escritores de la Resistencia y la distancia que asume el narrador desvaloriza las tareas políticas de estos intelectuales: "pequeños desplazamientos y escaramuzas sin mayor importancia excepto, claro está, para el gremio de los literatos" (32). El único que corre un poco de peligro es Leprince quien ni siquiera defiende la causa por convicción ideológica y es, como ya dijimos, un pésimo escritor. Queda demostrado que la heroicidad que puede aparejar el compromiso no es suficiente como instancia de legitimación de un escritor. Él sigue siendo una sombra, "su presencia provoca un rechazo intraducible, inclasificable. Lo saben a su lado, pero en el fondo se niegan con todas sus fuerzas a aceptarlo" (33). Entonces aparece otra posibilidad: transformarse en el marginal sin rostro, en un escritor secreto. Esto 
tampoco lo conduce al éxito y así, Leprince acepta su condición de mal escritor pues ninguna estrategia es válida si se carece de un proyecto creador positivo.

En el otro extremo del compromiso y la militancia, “Enrique Martín” también es la historia de un escritor malo narrada por Arturo Belano. Enrique Martín es un poeta patético cuya obra solo conocen sus amigos ("poetas sudamericanos perdidos en Sudamérica con quienes mantenía una correspondencia irregular, entre abrupta y dolorosa, fiel reflejo de nosotros mismos que comenzábamos a dejar de ser jóvenes, a aceptar el fin de los sueños”, 44) y escribe en revistas de pésima calidad (ni siquiera relacionadas con literatura). De repente se transforma en el "poeta de lo oculto", al escribir crípticos sin sentido y mostrar una obsesión con un "más allá", como una especie de simbolista teosófico. El relato adquiere los modos del misterio: hay algo que Enrique sabe y tiene que develarse. El suicidio del poeta suma tensión, entonces el narrador investiga y -junto con el lector- espera enfrentarse a algún dato revelador, pero nada sucede: el cuento culmina decepcionado a ambos, lector y narrador. El misterio en el arte de Martin resulta ser un montón de pésimos poemas ante lo cual al narrador solo le resta salir corriendo.

El recorrido de esta primera sección traza el escenario literario de la posdictadura en las dos caras de los ochenta: primero, el furgón de cola de la utopía, rescatando la figura del escritor comprometido y destacando la figura del sobreviviente de las utopías fracturadas; segundo, el paso a la postutopía signada por las redes tensas que el mercado impone. Son las figuras de A y B que ni siquiera tienen nombre, como meras letras vacías que problematizan también la noción de campo literario como un espacio vacío de luchas por dinero y prestigio relegando lo literario a último plano.

"Una aventura literaria" lleva al paroxismo las luchas internas del campo literario que pierden sentido, y sobre todo se alejan de la literatura. A y B son escritores que ocupan posiciones antagónicas: B carece del capital simbólico de A, el poder acumulado gracias a su respetada fama sobre todo a partir de sus ventas editoriales que se erigen como principal motor del éxito y la academia, como espacio de consagración indiscutido: “A es famoso, tiene dinero, es leído, las mayores ambiciones (y en ese orden) a las que puede aspirar un hombre de letras" (52)

Este relato nuevamente figura la relación literatura y mercado como rasgo característico de la dinámica del campo literario. La existencia de un mercado específico supone para Bourdieu la diferenciación entre productores (escritores) y consumidores (público lector) y la aparición de intermediarios: casas editoras, instancias 
de consagración y legitimación específicas (academias, premios). Los modos de producción y circulación están regidos por la lógica de "la producción y la gran producción" (Bourdieu, 1992). En "Una aventura..." es A quien ocupa una posición central en el campo siguiendo esa lógica, "quien se ha servido de la literatura para alcanzar una posición social, una respetabilidad, y desde su torre de nuevo rico dispara sobre todo aquello que pudiera empañar el espejo en el que ahora se contempla (52)

El narrador cuenta cómo B comienza a ingresar al circuito: la crítica de A le otorga a B el capital simbólico necesario para ser aceptado por sus pares y por el público, su éxito en el mercado es también garantía de valor (es la primera vez que publica en una gran editorial). Esta lógica vertiginosa (B no comprende la rapidez voraz de la crítica, en estrecha relación con la editorial) supone un pacto desgarrador: B era ajeno a esos mecanismos nefastos y al verse como un engranaje más sufre de paranoia "su sistema nervioso desgastado por tantos años de trabajo y anonimato" (57), "la comida le sabe a tierra, a materias putrefactas, a sangre. El frío del restaurante lo cala hasta los huesos. Esa noche enferma del estómago y a la mañana siguiente se arrastra como puede hasta el ambulatorio" (56) La paranoia de B que en los modos del relato recuerda la textualidad del policial, o la novela de espionajes, se basa en la posibilidad de confirmar lo irreconciliable: ¿puede ser A un buen escritor a pesar de la dinámica que encarna? "A sabe escribir, piensa B con desgana, tal vez con resignación” (55). Parálisis e inacción caracterizan a B (y luego al relato mismo): "Al final B no llama a nadie", "Finalmente B no hace nada" (56). Luego sabemos que no existen las conversaciones conspiradoras, ni las armas que B se imaginaba; y cuando se produce el anunciado encuentro entre A y B nada sucede: "Por fin, dice A, cómo estás. Muy bien, dice B" (62). Este final del cuento de lo más trivial (la violencia o el melodrama esperado quedan fuera de escena) hecha luz sobre los decorados y fachadas del denominado campo literario que está signado más por la competencia que por lo literario. Estos escritores solo tienen entidad a partir del mercado.

"Llamadas telefónicas" es el cuento que cierra esta primera sección y que, además, por dar nombre al volumen puede funcionar como clave de lectura para el resto en tanto condensa y proporciona un compacto de formas y temas: anticipa personajes y sus relaciones, estructuras y temas. La trama presenta a $\mathrm{B}$ enamorado de $\mathrm{X}$ quien lo abandona (por teléfono) y B hace todo lo posible por volver a reencontrarse. Los rasgos de B son compartidos por otros personajes (y narradores) del contario: alguien exiliado y pobre en España. X tiene características similares a Clara, Anne o Sofía, protagonista 
de otros relatos ("X cada día bordea el tratamiento psiquiátrico (pastillas, muchas pastillas que sin embargo en nada la ayudan), llora a menudo y sin causa aparente"). También todos los personajes de Llamadas telefónicas en su conjunto pueden ser el mono con el que B sueña "un mono de nieve que camina por el desierto" (63). "El camino del mono es limítrofe, abocado probablemente al fracaso. Pero el mono prefiere no saberlo y su astucia se convierte en voluntad: camina de noche, cuando las estrellas heladas barren el desierto" (64). Estos seres dislocados, extraños al paisaje traman relaciones que conducen a la nada, al vacío o a la muerte. La llamada telefónica, que está presente en varios de los relatos, funciona como metáfora del desesperado afán por la comunicación, una religación al mundo que se sabe inalcanzable, imposible (son llamadas telefónicas: la distancia es inherente a ellas.) La forma también habla de lo mismo: "Hasta aquí la historia es vulgar; lamentable pero vulgar" (65) este corte genera en el lector una sensación de que algo está por ocurrir. Entonces ingresan nuevos personajes, A y Z, que son policías; hay un homicidio, un viaje y otra vez el vacío, lo anunciado cae en la nada. Decepcionado, el lector comprende que la intriga es simplemente la de un amor desdichado.

En esta primera parte se erigen entonces diversas figuras de escritor encarnadas en distintos personajes autores y en el narrador a partir de una deconstrucción de la noción misma de campo literario. Un espacio fracturado que será eje también en Los detectives salvajes no solo a partir del impacto violento de la derrota latinoamericana, del terrorismo de Estado sino también a raíz de sus herencias que se hacen visibles en un nuevo escenario (derivado del anterior) que tiene como eje al mercado neoliberal. Si en "Sensini”" Bolaño evoca casi con ternura y melancolía esas instancias, que él mismo comparte en sus comienzos, de concursos y premios literarios para sobrevivir es precisamente porque destaca la imagen del sobreviviente de un horror que aniquiló todo marco de referencia al cual asirse. En cambio, desde "Una aventura literaria", la contrafigura del escritor a finales del ochenta y en los inicios de la década del noventa carece de la épica del concurso de provincia. A Sensini no le queda otra que enviar sus cuentos a concursos, y envía la misma pieza con diferentes títulos que son en sí mismos reductos de lo literario -sobre todo a partir de las metáforas que invocan- mientras que con A y B la literatura brilla por su ausencia, porque son devorados por los engranajes del mercado feroz y la competencia vacía que Bolaño discute con insistencia.

En el texto incluido en el volumen de cuentos El gaucho insufrible, "Los mitos de Chtulhu" (Bolaño, 2004), con un tono que invita a la polémica, expresa in extenso las 
poses y los conformismos de las nuevas figuras que instala el cambio de época en el espacio latinoamericano:

Ahora es la época del escritor funcional, del escritor maratón, del escritor que va al gimnasio, del escritor que cura sus males en Houston o en una clínica de Nueva York (171)

En este texto Bolaño exageradamente destruye la figura de nuevos escritores ("hijos tarados de García Márquez, hijos tarados de Octavio Paz", 173) envestidos con el glamur de las estrellas de Hollywood (172), exponiendo la idea de intelectual vacío, aferrado a los circuitos consagradores que se miden en fama y dinero. Sin negar el mercado (más bien denegándolo, en términos de Bourdieu), todavía cree posible un intelectual que "apuesta a favor del sentido crítico y por lo tanto se niega a aceptar fórmulas fáciles o clisés estereotipados" (Said, 1993). Por ello, en los cuentos analizados de Llamadas telefónicas hay pequeños actos de resistencia contra la lógica neoliberal. En "Enrique Martin" el narrador no va al cóctel de la editorial o la presentación de sus libros, y en "Una aventura literaria" B acepta con resignación a A, su mundo de editoriales y "lectores de las editoriales, esa subcasta aborrecible" (30, "Henri Simon Leprince")

En Llamadas telefónicas, desde "Sensini" como relato matriz se extenderá a otros actores y latitudes donde la impronta de la violencia aparece sesgada. Así, la segunda y tercera partes de Llamadas telefónicas recorre el mapa latinoamericano fuertemente marcado por la experiencia de los horrores de la historia política e incluye otros núcleos complejos para pensar el arte en ciertas coyunturas (Rusia, Alemania, España). El tópico del viaje aparece con las marcas del exilio, la dispersión y la pérdida de un rumbo definido. Los protagonistas son las mujeres-fantasma como paradigmas de una generación fracturada, o los hombres que dejaron de ser lo que eran. Como "El gusano" quien parece haber tenido un pasado interesante y su presente es el vacío, una "precariedad que lo rodeaba y lo carcomía" (79), la nada misma, ya "no discutía nunca, tampoco expresaba opiniones (...) simplemente escuchaba y almacenaba, o tal vez solo escuchaba y después olvidaba, atrapado en una órbita distinta a la de la otra gente. (7879). Por eso el cuento central de la segunda sección es "Detectives", de este relato en particular nos ocuparemos más adelante, junto con "Compañeros de celda" en el capítulo donde abordamos el fantástico en la narrativa de Bolaño. 
En "Otro cuento ruso" puede leerse ese desplazamiento hacia otros espacios que también refieren un contexto de horror. El marco de la Segunda Guerra sirve para explorar la relación entre arte y violencia a través del equívoco del soldado español que se salva de la tortura en la confusión entre ‘coño' y 'Kunst. Al mismo tiempo Bolaño juega con las palabras para hacer un guiño hacia la desacralización del arte (Kunst). Por último, en "La nieve" el personaje que cuenta la historia de toda una generación es chileno (¿Amalfitano?) y comienza su relato enunciando la contradicción que resume origen y destino de esa generación que ha perdido todo parámetro que la contenga: "mi familia era proletaria, con conciencia de clase, luchadora y con una honradez a prueba de fuego. Yo a los trece años robé una bicicleta" (85).

Las herencias de la dictadura se leen en la tercera parte, "Vida de Anne More", un compendio de biografías vertiginosas marcadas por la derrota. Las historias arman una red semántica en la que proliferan términos como: nada, frustración, desasimiento, incapaz, enmudeciendo. En "Joanna Silvestri" la voz narrativa es femenina, postrada en una clínica recuerda su pasado como estrella pornográfica, especialmente a su compañero Jack "como si su figura alta y flaca se estuviera desvaneciendo" (172), y concluye "todos somos fantasmas" (174). Sabemos, tras leer Estrella distante, que quien interroga a Joanna es el detective Romero que busca a Carlos Wieder, poeta y asesino en tiempos de Pinochet. El último cuento, "Vida de Anne Moore", es una puesta en abismo de lo que se relata, se anuncia un "estallido que avizoraba agazapado detrás de un día cualquiera" (186-187) pero lo único que estalla es la narración acelerada de acciones, que cuentan la vida de Anne, sus desplazamientos por diferentes ciudades, en una constante, y a la vez vacía, necesidad de movimiento, que no conduce nada.

Vemos cómo los textos de Llamadas telefónicas están integrados fundamentalmente por un eje que atraviesa la imagen del escritor latinoamericano en el pasaje que va de la postutopía al mercado en los ochenta y primeros noventa. ${ }^{85}$ Asimismo las herencias de la dictadura no solo anclan en el escritor sino en el conjunto de una sociedad fracturada, traumatizada.

\footnotetext{
${ }^{85}$ Explicita el mismo Bolaño en una entrevista: "Nunca nada que asumiera riesgos. La década del ochenta, que fue nefasta para Latinoamérica, creó una tipología que no solo se expandió en el ámbito literario, sino básicamente en el ámbito profesional, cuyo lema era ganar dinero, tener éxito, todo un rechazo absoluto al fracaso y un acriticismo por encima de todo" (Bolaño entrevistado por Melanie Jösh, "Primera línea", diciembre de 2000).
} 


\section{Putas asesinas: la juventud sacrificada}

Putas asesinas es el segundo volumen de cuentos publicados en vida de Roberto Bolaño (2001). Cualquiera de los calificativos que describan el tono, la atmósfera y los temas de este libro pueden aplicarse a algún otro. Ignacio Echeverría advierte cómo el motivo del llanto que recorre los relatos da cuenta cabal de una "épica de la tristeza" (2002: 194). Las lágrimas de los personajes -lee Echeverría junto con Bataille y el narrador de "Carnet de baile"- nos comunican algo: el punto justo, e inaprehensible, donde el enigma de la belleza se toca con la desesperación (194), cuando literatura y vida se saben cautivas de la violencia. Lo sabe el narrador que ya conocemos (aunque no siempre se explicite la identidad nominal) quien entra de lleno en el terreno que más conoce, no simplemente porque lo vivió sino por regresar una y otra vez en la repetición que vuelve lo real presencia, en el cuento que da inicio al texto: "de la verdadera violencia, no se puede escapar, al menos no nosotros, los nacidos en Latinoamérica en la década del cincuenta, los que rondábamos los veinte años cuando murió Salvador Allende" ("El Ojo Silva", 11). Como en Llamadas telefónicas la autoficción vuelve al tiempo de los primeros años en España, y Putas asesinas le añade el recuerdo mexicano, ese entre-lugar que refracta en la violencia que se quiere dejar atrás y las carencias que calan hondo cuando a lo lejos se sabe que de la violencia no hay liberación posible. Se puede ir hilvanando entonces las diferentes etapas de la biografía de Roberto Bolaño (la experiencia mexicana, la chilena y los años en Barcelona) en este gran relato de autoficción que arma en sus cuentos y novelas.

Todos los cuentos (con alguna excepción, como "Putas asesinas" o "El retorno", que sin embargo se integran de diferente modo al conjunto) ${ }^{86}$ están salpicados con datos de la biografía de Bolaño que por momentos puede ser la biografía de cualquier otro ("nacidos en los cincuenta"). Su familia decide instalarse en México en "uno de esos años-constelación" como dice Carlos Fuentes cuando coinciden hechos, movimientos y personalidades inesperadas: 1968. Cuando la Unidad Popular asume el poder en Chile Bolaño, con veinte años, decide regresar a compartir el entusiasmo inmediatamente

\footnotetext{
86 "Putas asesinas" resume la violencia condensada en otros relatos. Aquí una mujer desquiciada secuestra y tortura a un hombre, como acto d evenganza que nunca se explica (porque el hombre no la conce y ella lo confunde con otro). "El retorno" y "Buba" juegan con el fantástico desde un lugar humorístico y a la vez siniestro, el regreso de la muerte (el fantasma que sorprende al necrofílico) y la misteriosa posibilidad de cambiar el curso del destino (referida a la trivialidad de un partido de fútbol).
} 
truncado por la Junta militar de Augusto Pinochet en 1973. Vuelve a México a vivir los años de Los detectives salvajes para luego a fines de los setenta cruzar a Europa donde luego de viajar traza sus últimos itinerarios: Barcelona, Gerona y Blanes. Decir que la obra está cimentada en marcas autobiográficas es una obviedad, es preciso indagar cómo esos instantes recorridos cristalizan en los cuentos, se fugan y aparecen nuevamente en una y otra página.

El Ojo Silva cuenta cómo en la India una celebración prohibida por la ley pero no por la comunidad ofrece un niño a algún dios bajo la forma sacrificial de la castración. Estos niños castrados, de no más de diez años, una vez finalizado el ritual se convierten en víctimas rechazadas que terminan prostituidos en burdeles. El Ojo, fotógrafo periodístico, intenta encausar semejante cuadro a través de una foto ${ }^{87}$ como si fuese la única manera de procesar esa experiencia y a la vez de condenarlo para toda la eternidad (20). Es ahí cuando decide llevarse a los niños del burdel y volverse madre. La pesadilla de la persecución y la violencia no lo abandonan nunca y al morir los niños, enfermos, emprende el regreso que es un retorno a lo mismo: al llanto eterno, “por sus hijos muertos [...] por su juventud perdida, [...] por los jóvenes que murieron jóvenes, por los que lucharon por Salvador Allende y por los que tuvieron miedo de luchar por Salvador Allende" (25).

Se instala aquí el eje que vertebra los textos integrados de Putas asesinas: la “juventud castrada”. Esta imagen de la castración unida al sacrificio se articula a través de diferentes espacios que conforman la experiencia autobiográfica de Bolaño y aparece en el primer cuento ("El Ojo Silva") a partir del potencial metafórico que los relatos de Bolaño explotan. El desplazamiento a la India habilita el marco sacrificial ligado a la violencia que estos jóvenes -niños- padecen primero con la castración y luego cuando son arrojados a los burdeles. Esta imagen matriz del sacrificio y la castración está directamente vinculada, en el texto mismo, con la violencia latinoamericana.

El caso del "El Ojo Silva" es paradigmático y ejemplar (11), sentencia el narrador y más adelante reconoce: "de tan repetido es vulgar: la violencia de la que no nos podemos escapar. El destino de los latinoamericanos nacidos en la década el cincuenta" (22), es la frase calcada con la que inicia el relato y se despliega hacia todos los cuentos del volumen. Esta insistencia compulsiva emerge en otros relatos que

\footnotetext{
87 "Parecía una niña aterrorizada, dijo el Ojo. Aterrorizada y burlona al mismo tiempo. ¿Lo puedes entender? (...) Nadie se puede hacer una idea. Ni la víctima, ni los verdugos, no los espectadores. Solo una foto." (20)
} 
insisten en una visión de la izquierda exiliada sin rumbo, prejuiciosa y aburrida (el Ojo decide dejar México para que le pese su homosexualidad), circular, errante que se figura también en el motivo del viaje, cifra del extravío, el desapego y la indeterminación (Montes: 2011). Son instantáneas a partir de las cuales el yo es otro, es nadie o es todos.

En "Días de 1978” el protagonista es B y el narrador está tan cerca de lo narrado que a veces necesita la distancia ("Esto no lo digo yo, esto lo piensa B", 65) que ordena el fluir del recuerdo. El clima de exiliados chilenos en Barcelona, cuando B acaba de llegar de México, se evoca en una pelea inútil entre B y U, otro exiliado de izquierdas, que poco a poco avanza hacia la muerte, a través de la locura, el aburrimiento, la fragilidad y lo inevitable. Al principio es una anécdota más en los grupos de jóvenes exiliados reunidos para afianzar lazos, discutir, sobrevivir. Se describe el quiebre obvio de tal experiencia (dictadura y exilio) figurada en los espacios y atmósferas quebrantadas, fúnebres (una fiesta remite a conciliábulos fragmentados en diferentes habitaciones, 72) pero la figura de U que casi obsesiona a B se recorta desde el rencor y el horror para inyectar en el relato esa sensación -tan común al lector de Bolaño- de que hay algo más detrás de las escenas que se narran. La hija de un sindical asesinado inicia una conversación amable con B y U sobre una película. U sólo expresa que hace mucho que no va al cine. B transforma el tono de $\mathrm{U}$ en una extraña imagen, ${ }^{88}$ que envuelve el diálogo trivial con las sombras del horror, para luego comentar que él había visto la película y que era buena. Es el espesor del relato que transforma la cotidianeidad en algo funesto e inexplicable para regresar luego a la apariencia de lo normal. Y esta normalidad permeada por el horror vuelve al eje de la juventud sacrificada: $U$ se cuelga de un árbol.

Este tópico de la "juventud castrada/sacrificada" que permite leer los cuentos como textos integrados también rodea a la presencia de un yo narrativo que disemina ciertos datos asimilables a la biografía del autor -Roberto Bolaño- y que en la autoficción puede identificarse de diversas maneras: "Bolaño", Belano o B. Además, de este motivo matricial se desprende otro tópico que recorre el Hipertexto-Bolaño: el de la violencia soterrada, latente y acechante. Cada uno de los cuentos (aunque no todos ellos) explora el recuerdo de diferentes momentos de la juventud, marcado por las consecuencias de la dictadura militar, la estadía en México entre la violencia y la poesía

\footnotetext{
${ }^{88}$ Piensa en "una película en blanco y negro y muda en la que de pronto todos se ponen a gritar de forma incomprensible y ensordecedora mientras en el centro del objetivo una estría roja comienza a formarse y extenderse por el resto de la pantalla" (74).
} 
y el posterior establecimiento en Barcelona, frecuentando los círculos de exiliados latinoamericanos, intentando sobrevivir de concursos literarios y otros trabajos nada literarios. El tono del recuerdo se vuelve otro elemento integrador que permite dar cuenta de la construcción de un pasado borroso pero todavía punzante. El narrador vuelve a esos años de juventud no para reconstruir los acontecimientos vividos constantemente duda de la veracidad de lo narrado, asume el artificio de la memoria ("como casi todo en esta historia es improbable", "Gómez Palacio", 33)- sino para recuperar ciertos instantes que regresan con las marcas de un peligro que acecha o con la pesadumbre de la derrota. Cuando el narrador va a un pueblo perdido del norte de México ("Gómez Palacio") a dirigir un taller de literatura la cotidianeidad tranquila y lenta de ese lugar lejano y sus habitantes se transforma en atmósfera tensa y enrarecida. El narrador tiembla constantemente, está nervioso y paranoico. ${ }^{89}$

También unas vacaciones de $\mathrm{B}$ con el padre, en Acapulco, se tornan insoportables y están mediadas por el silencio y la espera de algo desastroso. Aquí, en "Últimos atardeceres en la tierra", el narrador ya no asume la primera persona, se trata de un narrador omnisciente en tercera persona -impersonal en tanto es más un ojo que sigue los pasos de B y su padre- cuya voz casi cinematográfica asume oraciones breves, descriptivas que, junto con el tiempo presente elegido para relatar estas vacaciones de 1975, generan un ritmo acelerado contrario a lo narrado, pues poco ocurre o, mejor, lo poco que sucede vale más por sus detalles que por sus acciones. Se abren paréntesis que focalizan en B y detalles que provocan esa capa densa de sensaciones oscuras que configuran la atmósfera de los cuentos de Bolaño y permiten que un relato de lo más trivial y simple evite convertirse en una prosa aburrida y monótona. Por ejemplo, un diálogo de hotel, entre una mujer que parece sentirse indispuesta y $\mathrm{B}$ abre la grieta de lo cotidiano hacia la amenaza: ella responde a B que sólo está pensando y B “de pronto percibe en esa declaración una amenaza. Algo que se acerca por el lado del mar. Algo que avanza arrastrado por las nubes oscuras que cruzan invisibles la bahía de Acapulco" (46). Ese peligro que se percibe como material se desvanece, como las nubes mismas, y solo puede referir una tormenta tropical más.

El narrador marca un quiebre en la historia cuando anuncia que el paréntesis de las cuarenta y ocho horas de vacaciones (de playa y restaurantes) se acaba para dar paso a un "período gélido" (56) signado por el aburrimiento -o el desastre, para B- que en

\footnotetext{
89 “Tenía pesadillas (...) se me secaba la boca y la única solución era beber agua” (29). "No sé por qué, pensé que eran policías y que habían ido a detenerme" (32).
} 
apariencia es normal pero está "dominado por unos dioses helados" (56). Es entonces cuando se abre una brecha entre B y su padre durante las salidas nocturnas y la aparición del ex clavadista, quien no es más que una compañía pasajera de vacaciones pero que se presenta como una amenaza.

Hasta una lectura de verano se transforma en indicio del "desastre" que se anuncia. De la antología de poetas surrealistas que lee B le interesa la biografía de Gui Rosey, figura menor del grupo, cuya breve historia el narrador intercala. ${ }^{90}$ Lo que llama la atención de $\mathrm{B}$ es la desaparición de Rosey (en Marsella donde se lo vio por última vez, cuando esperaba la visa para huir de Francia durante el nazismo) y cómo esa falta pronto cae en el olvido entre sus amigos "ocupados en ponerse a salvo a sí mismos, en unos años en los que las desapariciones masivas y los crímenes masivos son una constante" (42). Este dato de Rosey abre un arco hacia "las guerras floridas latinoamericanas" (59) como B expresa al referirse a las dictaduras militares. B recuerda su propia experiencia con la dictadura- según cuenta a su padre, sobrevivió dos veces. Esta experiencia de la violencia opresiva hilvana el eje de la juventud sacrificada en la identidad del poeta surrealista con quien el joven B se identifica. En la escena final del relato, Rosey y B son el mismo, B siente que él también puede desaparecer para siempre, “como Gui Rosey, un Gui Rosey enterrado en algún baldío de Acapulco" (63).

Sin embargo, en esta oscilación constante entre lo trivial y lo siniestro, el peligro que B presiente se reduce a una pelea de bar entre turistas. Myrna Solotorevsky (2010) postula leer el final del cuento ("Empiezan a pelear.") como culminante en tanto el desenlace fatal, donde $\mathrm{B}$ y el padre mueren durante la pelea, si bien no se narra se anuncia previamente reiteradas veces. La idea, dos veces repetida, que parafrasea la máxima del iceberg que Ernest Hemingway apunta para toda historia ("Hay cosas que se pueden contar y hay cosas que no se pueden contar", 54 y 61) avala el final abrupto donde nada se nos dice de la pelea y su final. La identificación de $\mathrm{B}$ con el poeta surrealista desaparecido también podría sustentar esta hipótesis (ambos mueren o desaparecen), sin embargo hay un detalle que la desestima porque en ese instante de peligro inminente que, tal vez sea lo que se viene anunciando, B se encuentra con su padre, "se da cuenta de que, al contrario de Gui Rosey, él no está sólo" (63) y piensa en

\footnotetext{
${ }^{90}$ Bolaño vincula el momento de la juventud con la poética (y la actitud) surrealista. La posibilidade poder ir más allá de lo real y la disposición vanguardista que deriva en el real visceralismo (como en Los detectives salvajes) y en los usos del fantástico (como veremos más adelante) configura otro potencial del surrealismo en la literatura de América Latina, uno de cuyos puntos nodales se constituyen en la noción de lo real maravilloso que Alejo Carpentier forja en el prólogo a El reino de este mundo.
} 
el regreso al DF con alegría" (63). Así, como en la mayoría de los relatos de Bolaño el peligro de desvanece y nada acontece.

"Vagabundo en Francia y Bélgica" también registra un viaje en tercera persona y B es el protagonista. B ya es un hombre que vive de la literatura (vagabundea porque le han depositado el $60 \%$ de un libro que no ha escrito aun), tiene un hijo, está enfermo (solo bebe infusiones de manzanilla) y recuerda sus veinte años y la amistad con L (¿Lima?) en México (84). Aquí, B está en España y decide salir porque "necesita sentirse en una zona de baja intensidad de peligro" (81). Este riesgo constante que persigue a los personajes de Bolaño suele diluirse sin más, pues el peligro no es lo que vendrá sino el eco de lo que ya ha venido. De manera que esta forma de armar el relato basada en los huecos y vacios que se abren a partir de la insistencia en un peligro que nunca se materializa, en una violencia agazapada que se filtra pero nunca se configura abiertamente, remite directamente a una experiencia previa sobre la que se vuelve insistentemente. Es la repetición de la memoria no tramitada, es el trauma que provoca el estadio melancólico del acontecimiento disruptivo no elaborado y por lo tanto siempre presente.

En "Vagabundo en Francia y Bélgica" es el encuentro con la literatura (también, como con Gui Rosey) lo que dispara el relato hacia zonas desconocidas - que nunca se conocerán. Henri Lefebvre cautiva a $\mathrm{B}$ desde el número de la revista Luna Park que adquiere en una librería de viejos. El dato biográfico de este poeta belga (que en el cuento no es el filósofo marxista Henri Lefebvre) que llama la atención de B es un año: 1973, cuando Lefebvre muere y los militares chilenos dieron el golpe de Estado (84). Las advertencias de peligro reaparecen en el texto como agujeros negros cuando mira los libros en la biblioteca de su amiga $\mathrm{M}$ que aluden al golpe de estado y a las comunidades mapuches (88) y siente el aviso de que algo no va bien, son una señal terrible (89). Entonces decide ir en busca de la casa donde el poeta murió pero nada encuentra, "ha sido borrado del mapa" (95) y explica a M que su deseo era rescatarlo del olvido, recordarlo.

El tópico de la búsqueda del escritor es recurrente en la obra de Bolaño pero adquiere diferentes matices y significaciones. En los cuentos que hemos analizado la búsqueda tiene que ver con el escritor desaparecido, con un fuerte anclaje en los momentos de violencia histórica. En algunas novelas (Wieder en Estrella distante, Tinajero en Los detectives salvajes, Archimboldi en 2660) esto se extiende también a otro tipo de búsqueda que tiene que ver con lo irreductible de la literatura, si termina en 
fracaso es porque el escritor se va develando en el movimiento de la búsqueda antes que en su resultado. Porque además no es posible instalar figuras faro que fijen sentidos allí donde no es posible hallarlos, en la literatura misma. Desde la óptica de la autoficción, en el juego de espejos que refractan al yo narrador y a los personajes en que puede fragmentarse las figuraciones de autor no podrán estancarse en una Künstlerroman o novela de artista acabada que dé cuenta de la formación de una identidad de artista porque el sujeto autor está siempre en proceso de construcción. Es a partir de dos recorridos que se fragua la autoficción: en el recuerdo de los horrores de la historia reciente y -a la par- a través de la literatura, en los momentos en que el yo se sabe escritor. El yo que regresa insistentemente al pasado, que toma la época de su juventud en México o de los primeros años de estadía en España como material narrativo, como trasfondo de sus textos insiste menos en individualizar la experiencia que en testimoniarla.

Lejos de construir una figura de escritor contemplativo quien desde la madurez o la enfermedad- siente nostalgia por la juventud perdida, la autoficción de Bolaño rebalsa vitalidad y humor de modo que si sobreviene la melancolía es porque el relato vuelve anclarse siempre en aquella juventud perdida de verdad en lugares ignotos del cementerio latinoamericano. Bolaño se configura así como el escritor melancólico que no sale de la experiencia de la violencia, que vuelve sobre el mal radical a través de varias posibilidades estéticas combinadas con la ironía y el humor que lo caracterizan (el fantástico, el policial) y evitan cristalizarlo en una zona nostalgiosa y lacrimógena porque la vuelta insistente del pasado se emprende desde un presente melancólico y fuertemente crítico.

La imagen que en Los detectives salvajes define a los poetas real visceralistas es clave: ellos caminan hacia atrás, se dirigen al futuro pero anclando la mirada en el pasado: "De espaldas, mirando un punto pero alejándose de él, en línea recta hacia lo desconocido" (17). La autoficción se nutre con el recuerdo de hechos que han sucedido tiempo atrás y se actualizan en la escritura, así el pasado recordado es aún pasado reciente, mantiene su presencia y al repetirse, nunca idéntico, intenta conjurarse.

El secreto del mal (2007) reúne diversos textos, más que cuentos son esbozos, borradores o posibles comienzos, que sin proponérselo vienen a corroborar, por si quedaban dudas, la "poética de la inconclusión” que Ignacio Echeverría resalta en la nota preliminar (2007: 8) y la presencia insistente de la vida en la literatura, y viceversa. 
En términos de la autoficción que venimos apuntando, el sujeto insiste en narrarse aunque se sabe fragmentado y afectado por ese recuerdo que se vuelve presencia en la escritura. Aun en los textos que solo parecen ser instantáneas de la memoria en momentos cotidianos la tensión del relato aflora para revestir la lectura de un estado constante de alerta (que luego se esfuma). "La colonia Lindavista" (El secreto del $\mathrm{mal}$ ) presenta un narrador en primera persona que inmediatamente se identifica con el recorrido biográfico de Bolaño: la llegada a México en 1968 con sus padres y su hermana, la posterior residencia en Blanes. ${ }^{91}$ Aquí se describe la estadía durante el primer año en México desde el lento transcurrir de la cotidianeidad y los pormenores de sus vecinos y cómo los primeros ejercicios nocturnos con la escritura se acompañan con los ecos de los juegos sexuales de Pepe y Lupita (los del piso de arriba). El narrador intuye que algo raro (19) sucede más allá del cielo raso pero no da ningún indicio acerca su naturaleza. El recuerdo de esa época tranquila se percibe como "una desolación abrumadora" (20). Si bien parecen gérmenes de textos futuros, los relatos de El secreto del mal afirman la poética de Bolaño en esa zona liminal entre lo cotidiano y le horror.

Dos relatos, desde un narrador en tercera persona omnisciente, tienen a Arturo Belano como protagonista. "El viejo en la montaña" recuerda el momento en que la amistad entre Belano y Ulises Lima se inicia "al borde del abismo" (29) -casi la macroestructura de Los detectives salvajes- pasan los años y Belano se establece en un pueblo sobre el Mediterráneo (29) mientras que Lima regresa al DF donde salva su vida de milagro al ser atropellado por un autobús (30). En otro relato, "Muerte de Ulises", Belano ya tiene cuarentaiséis años, está mal del hígado y es un escritor con mayor notoriedad que reniega de cumplir invitaciones a congresos y eventos literarios (169) por lo que decide olvidarse de sus obligaciones profesionales y volver a encontrarse con su pasado en México. Recorre los espacios antes transitados y visita la casa de Ulises Lima, atropellado mortalmente por un Impala negro, un coche misterioso que será también señal de muerte en Santa Teresa en $2666 .{ }^{92}$

La topografía del recuerdo puede llevarnos a pequeñas anécdotas que cifran momentos que se vuelven trascendentes a partir de su articulación con la escritura. Como la actitud extraña del hijo, Lautaro, de orinar en la piscina desde el borde (y no

\footnotetext{
${ }^{91}$ En "Muerte de Ulises", Belano regresa a México luego de veinte años y recuerda los días en la colonia Lindavista.

92 Junto con Mario Santiago Papasquiaro (1953-1998) Roberto Bolaño funda el movimiento infrarrealista en el México de los setenta. Santiago será dos veces atropellado, no sobrevive la última vez. Ver: Edgardo Dobry "El detective verdadero", Babelia - El País, 10 enero 2009.
} 
con disimulo en su interior) que en "No sé leer" el narrador explica a través de un sueño: "Si a mí me hubieran matado en Chile, a finales de 1973 o a principios de 1974, él no habría nacido (...) y orinar desde el borde de la piscina, como si estuviera dormido (...) era como reconocer gestualmente el hecho y sus sombra: haber nacido y la posibilidad de no haber nacido, estar en el mundo y la posibilidad de no estar" (El secreto del mal, 116). Nuevamente una escena trivial cifra el horror.

Otro terreno de donde surge el relato son las fotos. En "Fotos", de Putas asesinas, Arturo Belano está en África y hojea un álbum de fotos de poetas franceses que sirven de base para una suerte de fluir de la conciencia (nueve páginas de un solo párrafo, sin punto) que alterna entre la primera y la tercera persona en un vaivén de pensamientos sobre la juventud, la poesía y los espectros. En "Laberinto" (El secreto del $\mathrm{mal}$ ) el recurso se intensifica al generar pequeños relatos a partir de la fotografía que reúne a intelectuales franceses en los setenta (Henric, Goux, Sollers, Kristeva, Réveillé, Guyotat, C. y M. Devade). Entre los datos objetivos aparentemente derivados de la foto se abre la grieta del relato que extrae a los protagonistas del instante muerto de la imagen y los vuelve a la vida, los vuelve relato. Fernando Moreno (2011) parte de la lectura de este cuento para definir "la estética laberíntica" de Bolaño que caracteriza su cuentística (intertextos, microrrelatos, fractalización de voces, opacidad, elisión de desenlace convencional, entre otras, 341). Moreno muy bien señala lo que el narrador realiza con la foto de "Laberinto" y el procedimiento puede trasladarse a los modos con los que Bolaño reconstruye el pasado y consolida así su autoficción. Al inspeccionar cada milímetro de la imagen, al escrutar sus detalles, el relato avanza para "introducirse en lo escondido (...) en lo que no puede percibirse sino mediante estas incursiones que incluyen en un mismo nivel tanto certezas como suposiciones" (Moreno 2011: 335). Tal síntesis le cabe al libro de arena de Bolaño: el constante juego entre literatura y vida, entre el pasado y su escritura que signan su contemporaneidad como escritor latinoamericano marcada por la presencia oculta de un terror ya vivenciado que insiste en volver al presente.

Esto se resume magistralmente en "Carnet de baile" (Putas asesinas) donde sesenta y nueve puntos, a modo de lista, recorren diferentes aproximaciones a una posible autobiografía de la lectura, la biblioteca de la formación atravesada por la sombra de Pablo Neruda (que hay que espantar con Nicanor Parra) y la poesía. Y en medio de las lecturas y los desplazamientos (Chile, México, Chile) se levanta el horror de las dictaduras, la ubicuidad de la tortura y la muerte. La anécdota repetida en 
diferentes versiones de una militante del MIR torturada que luego muere de tristeza puede invertir el poema "Masa", de César Vallejo, pues en América Latina quienes se multiplican son los muertos. Y la mayoría, en los libros de Bolaño, son poetas de modo que el final de Putas asesinas es inmejorable: un encuentro onírico con Enrique Lihn y con Jara donde "Bolaño", personaje y narrador, corrobora la existencia fantasmática de la literatura chilena donde "sólo los muertos salen a pasear" (225). La cuestión radica en qué hacer y dónde encontrar a los sobrevivientes, cómo articular una vida de escritor después de la experiencia del trauma.

Las imágenes de poetas que trashuman el libro de arena de Bolaño son figuras pequeñas en el desierto de la literatura. Revisten siempre los rasgos de la marginalidad, la melancolía y la pobreza. Así lo resume la frase inicial y solitaria del cuento "Dentista" (Putas asesinas): "No era Rimbaud, sólo era un niño indio" (175). José Ramírez es un joven de dieciséis años cuya obra conmueve al narrador y a su amigo dentista. "Campesinos, muertos de hambre" (190), en su casa paupérrima (de donde el narrador quiere salir lo antes posible) se abre el agujero real (188) en la lectura de los cuentos del joven que cautivan al narrador y le hacen comprender el misterio del arte (195). En El gaucho insufrible aparece "Jim", el norteamericano más triste, y desesperado, que haya visto nuestro narrador. Jim es vagabundo, veterano de Vietnam y poeta. El desamparo que rodea a los escritores bolañanos se corresponde con la idea de una literatura a la intemperie, es decir alejada de los circuitos institucionales de consagración y mercado. Y por sobre todas las cosas los escritores de Bolaño son sobrevivientes. 


\title{
III. 4. Los detectives salvajes, fragmentos de una biografía de América latina en su literatura
}

\author{
A medio hacer, ni crudos ni cocidos, bipolares capaces de cabalgar el huracán
}

Roberto Bolaño, "Un paseo por la literatura"

Con Los detectives salvajes (1998) Roberto Bolaño ingresó a los estantes de la literatura latinoamericana no sólo de la mano del premio Herralde y el Rómulo Gallegos si no de los numerosos comentarios críticos y reseñas -tanto desde la academia como desde los medios de comunicación- que colocaban la novela en la línea de grandes obras colosales, rupturistas y a la vez canónicas (desde el Ulises de Joyce a Rayuela de Cortázar) y visibilizaban al escritor chileno en un campo literario latinoamericano con supuestas necesidades de renovación. Así lo demuestra la recepción crítica de Grinor Rojo $^{93}$, por ejemplo, cuando lee la muerte de Cesárea Tinajero como señal de un recambio generacional renovador en el cual la voz de Bolaño se erige con más ímpetu. ${ }^{94}$ Los diversos registros, las múltiples voces, los diferentes lugares por donde fluyen las historias configuran una trama en la que cobra un nuevo protagonismo el tópico de la juventud castrada/sacrificada, marcada por el vacío generacional tanto político como literario que marcó el paso de los años sesenta-setenta a los noventa. Si es evidente que la novela pone en cuestión toda imagen idílica del pasado revolucionario latinoamericano -insistimos, tanto político como literario-, también socava todo intento por esencializar lo latinoamericano precisamente en la novela que lo revela como escritor consagrado y lo presenta desde México, desde América Latina al mundo. Es decir, con Los detectives salvajes Bolaño no solo ingresa al canon editorial y crítico sino que se construye así mismo como un escritor latinoamericano.

\footnotetext{
${ }^{93}$ De los críticos ya consagrados, por decirlo de alguna manera, fue Rojo junto con José Promis y Jorge Edwards quienes se ocuparon tempranamente la obra de Bolaño en un ámbito chileno poco amigable para el escritor ya instalado en Barcelona. Respecto de la posterior recepción de Bolaño en el ámbito anglosajón ver Corral Wilfrido (2011)

${ }^{94}$ Señala Rojo: "La muerte de Cesárea Tinajero, primera vanguardista de México, es esencialmente, en la novela que nos ha proporcionado Roberto Bolaño, la muerte de una cierta manera de concebirse el escritor a sí mismo y de concebir su creación. Es, en buenas cuentas, la muerte de un arte y una literatura de los que Octavio Paz [...] es el más celebrado de sus representantes" (2003: 72-73)
} 
Entonces Los detectives salvajes condensa el núcleo fundamental del HipertextoBolaño en dos direcciones. En primer lugar, recupera esa generación perdida que sufrió la violencia de las dictaduras militares y que, también, perteneció de algún modo a la izquierda revolucionaria. Sin embargo, los vínculos que se establecen con el pasado de la izquierda latinoamericana son complejos debido a que evita una reivindicación de los ideales de la lucha armada y rechaza la mitologización de una épica nostálgica de la revolución. Bolaño recupera este aspecto de la historia reciente desde diversos espacios que privilegia en tanto se conectan directamente con su biografía. En principio, está Chile y el Golpe de Estado de Augusto Pinochet; luego aparece México con el emblema de Tlatelolco y otros modos de la violencia localizados en el desierto y la frontera (Santa Teresa-Ciudad Juárez). En segundo lugar, toda su obra dialoga con la tradición literaria latinoamericana armando diferentes cartografías culturales que incluyen desde la poesía chilena y la narrativa argentina a los movimientos más continentales que se nuclean en torno a las vanguardias desde los años veinte, el momento del boom latinoamericano y llega a la literatura reciente en la década de los noventa.

Cuando Wilfrido Corral pone en tela de juicio las reducciones que la crítica mundial plantea al limitar la obra de Bolaño en los resabios del boom, a partir de la literatura latinoamericana más estereotipada, acierta y también acierta cuando afirma que Bolaño desencaja, que no puede confinarse a clisé nacionales ni siquiera desde las llamadas "novelas chilenas" (como Nocturno de Chile o Estrella distante) (2011 97-98). Sin embargo, no compartimos la afirmación que expulsa a Bolaño de la literatura latinoamericana aun cuando quiera defenderse una literatura mundial. Es desde América Latina que Bolaño ingresa al "mundo" y su propia obra no deja de confirmarlo porque forja una identidad latinoamericana que no es esencialista sino histórica debido a que su obra se ancla en las experiencias dictatoriales en Chile y en el Cono Sur para luego extenderse a América Latina. Y porque además se autoconsagra latinoamericano a partir de la recuperación -crítica, sobre todo- de su tradición, lo que no impide su ingreso a la "literatura mundial".

El proyecto de Bolaño se impone no sólo rescatar a América Latina como locus de enunciación sino también como experiencia cultural que contra ligeros clisés o intentos evanescentes, sin embargo, todavía permite sostener críticamente -socavándola al mismo tiempo- la etiqueta "literatura latinoamericana". El íncipit del HipertextoBolaño es Chile, el Cono Sur y América Latina en la experiencia desgarradora de la violencia dictatorial pero el relato no se folkloriza -ni se vuelve aldea- debido a que las 
fronteras se abren hacia otros espacios, otras tradiciones, otras historias, otras literaturas. Por eso no hay una "pérdida del espacio identitario latinoamericano" (Rial 2011: 145) sino su transformación y proliferación.

Los detectives salvajes retoma las cuestiones abordadas en los apartados anteriores, aquí Bolaño recupera las biografías de escritor para dar cuenta de la historia literaria latinoamericana del siglo XX en una colosal pretensión de abarcar sus momentos más trascendentales. En esta novela, repasa los diferentes momentos que conforman su autoficción donde reelabora la llegada a México con su familia, su viaje a Chile en los meses previos al Golpe, la experiencia de la dictadura, el regreso a México, los primeros años en Barcelona. La novela ficcionaliza particularmente la etapa infrarrealista en la que un joven Bolaño se va haciendo poeta. Los amigos de esta época en México (desde 1968 hasta 1977, con el quiebre que marcó su regreso breve a Chile en 1973) cambian de nombres y aparecen en la novela junto a escritores ficcionalizados que mantienen su identidad (como Manuel Maples Arce, Carlos Monsiváis, Octavio Paz) para revisar la experiencia mexicana a partir del movimiento poético que Bolaño funda con Mario Santiago (Ulises Lima en la novela), entre 1975 y 1975: el infrarrealismo (que se transforma en real visceralismo). ${ }^{95}$ Entre beatniks, surrealistas y jóvenes rebeldes de los talleres de poesía el grupo tiene su manifiesto, firmado por Bolaño en 1976: "Déjenlo todo, nuevamente". Los detectives salvajes explora esa época en la que se forja la historia intelectual de Bolaño y es a partir de esta autoficción que el autor repasa sus inicios en la poesía, los cimientos como escritor, a la vez que reflexiona sobre su concepción y posición respecto de la literatura.

La novela se divide en tres secciones, la primera y la última son parte de las entradas del diario de Juan García Madero, quien cambia la Facultad de Derecho por los grupos de poesía y da cuenta de las vivencias y búsquedas de un grupo de jóvenes que se autodenominan "real visceralistas". Sus fundadores, Ulises Lima y Arturo Belano, serán los protagonistas del relato que García Madero arma en su diario. Desde un la primera parte, en "Mexicanos perdidos en México (1975)", la incertidumbre respecto de

\footnotetext{
${ }^{95}$ En "Como veo doy, una mirada interna del Movimiento Infrarrealista", Ramón Méndez Estrada explica: "Idea de Roberto, la explicaba como una metáfora: a quienes cometimos el pecado de rebelarnos contra una de las glorias nacionales de la poesía nos tenían vetados en todas las publicaciones y espacios culturales de México; decía que éramos como soles negros, de esos que no se ven pero que atraen la luz, materia condensada a tal grado que hace caer a la energía por su peso, y auguraba que nosotros haríamos la literatura clásica de nuestro tiempo" (Publicado en La Jornada Morelos el 9 de marzo de 2004, disponible en www.infrarrealismo.com)
} 
qué es el realismo visceral aparece y así aunque parece que el narrador intenta caracterizar el grupo nunca se enuncian certezas sino más bien impresiones (solo está claro que proclaman a Octavio Paz su acérrimo enemigo). Las sensaciones que García Madero detalla en su primer encuentro con los real visceralistas se tiñen de un halo misterioso, entre lo extraño y lo banal. El adjetivo que utiliza para describir la escena es "maravilloso" cuando en verdad lo que sucede es una discusión mediocre ("batalla", para García Madero, (15) entre Julio César Álamo, director del taller de poesía, y Lima y Belano. Con el objetivo de cambiar la poesía mexicana (30) y crear asimismo un movimiento a escala latinoamericana (36), los real visceralistas no pasan de ser una pandilla (17) de jóvenes latinoamericanos que viven con frenesí poético la antesala del horror. Arturo Belano y Ulises Lima son los líderes del grupo, y parecen dos fantasmas (113), encarnan la poesía en estado puro, la que no se sustenta con "becas ni espacios en sus revistas ni siquiera invitaciones para ir a presentaciones de libros o recitales" (113). Desde un margen construido a base de imprecaciones e irreverencias estos jóvenes más que escribir poesía la exudan, lectores voraces que buscan la poesía antes de crearla (la “obra completa” de García Madero: 76 páginas, 55 poemas, 120) ${ }^{96}$ y esta búsqueda no se emprende mirando solamente a los poetas europeos, padres de la poesía moderna y la vanguardia sino al interior mismo de la tradición latinoamericana.

El real visceralismo surge de un trabajo que Belano y Lima realizan sobre el estridentismo. Allí descubren la existencia de una mujer, que sería la única del grupo y la mejor de todos. Sin embargo, luego aprenden que Cesárea Tinajero, cercana a los estridentistas, funda su propio movimiento que bautiza como "real visceralismo". Así, este dato perdido en la historia literaria de los años treinta cautiva a Ulises y a Arturo y deciden seguir los pasos de Tinajero y refundar un movimiento en su memoria.

Los detectives salvajes de la poesía latinoamericana buscan las pistas perdidas de la matriz de la poesía que encarna en Césarea Tinajero, como origen de una estética y una ética que sean una "entrada en aventura", para "hacer aparecer las nuevas sensaciones -Subvertir la cotidianeidad", ${ }^{97}$ como apuntó Bolaño en el Primer Manifiesto

\footnotetext{
96 “'A mí, a los 20 años, más que escribir poesía, porque escribía también poesía (en realidad sólo escribía poesía), lo que me interesaba, lo que yo quería era vivir como poeta, aunque ahora no podría especificarte qué es lo que, para mí, era vivir como poeta. Pero mi interés básico era ése, vivir como poeta. [...] Estábamos contra el trabajo. Entre otras cosas éramos flojos incansables, no había quién nos hiciera trabajar, yo trabajaba para vivir cuando no me quedaba más remedio" (Bolaño por sí mismo 38).

97 "Nuestra ética es la Revolución, nuestra estética la Vida: una-sola-cosa.", "El riesgo siempre está en otra parte. El verdadero poeta es el que siempre está abandonándose. Nunca demasiado tiempo en un mismo lugar, como los guerrilleros, como los ovnis, como los ojos blancos de los prisioneros a cadena perpetua."
} 
Infrarrealista en 1976. A la sentencia de Ernesto San Epifanio que anuncia que Césarea es el horror (85) se suma el hecho de que Ulises, Arturo y García Madero emprenden la búsqueda de la poeta al tiempo que escapan de los matones que amenazan a Lupe.

En la huida se cifra el fracaso que la tercera parte de la novela, "Los desiertos de Sonora (1976)", confirma en el corazón del desierto mexicano, en pueblos fantasmas, pueblos de asesinos y asesinatos (Villaviciosa y Santa Teresa). El grupo conformado por Belano, Lima, García Madero y Lupe emprende el rastreo de los pasos perdidos de Cesárea, poeta vanguardista de los años veinte y treinta, con una obra breve y exigua. Las pistas son escasas y sin embargo no desalientan a Arturo y Ulises que buscan indicios en la prensa, archivos parroquiales, bibliotecas o universidades de pueblos perdidos en el desierto mexicano. En un diario de Santa Teresa de 1928 encuentran una mención a una tal Cesárea Tinaja, mujer del torero Pepe Avellaneda, y renuevan las esperanzas del hallazgo a pesar de la reticencia del narrador. García Madero es más realista que visceral cuando al contar que sus amigos interpretan el cambio de apellido como una broma para despistar ${ }^{98}$ y añade con distancia: "yo no me atrevería a decir tanto con tan poco en donde sostenerse" (571). Los testimonios que recopilan datos insignificantes nada tienen que ver con poesía, como el del ex torero Ortiz Pacheco. La pista final es la de Flora Castañeda, la maestra colega de Cesárea. Sus recuerdos revisten un tono misterioso y lúgubre (ella menciona a Hipatía ${ }^{99}$ y los vaticinios extraños sobre el 2600 y pico) acerca de una Cesárea desmesuradamente gorda, puestera de feria (598) que los poetas encuentran en Villaviciosa.

El esperado hallazgo no entusiasma ("Césarea no tenía nada de poética. Parecía una roca o un elefante", 602), antes bien confunde. Se narra a medias, como entre nieblas, debido a que García Madero no logra comprender los hechos, se queda dormido y sólo relata acciones vacías de contenido ¿de qué hablaron Cesárea, Ulises y Arturo? ¿por qué abandonan todos la casa de Cesárea en dirección al desierto? La respuesta la da Belano unas páginas más adelante: "oí que Belano decía que la habíamos cagado, que habíamos encontrado a Cesárea sólo para traerle la muerte" (605). Los cinco ocupantes del Impala son interceptados por el Camaro en el que Alberto y su secuaz los

\footnotetext{
${ }^{98}$ Ulises y Arturo justifican el cambio de apellido debido a una errata o incluso a "una broma, una forma humilde de tapar una pista humilde" (571). ¿Césarea prevé que dos poetas la buscarán? ¿o es simplemente una construcción de Lima y Belano que unifica poesía con experiencia, enigma, búsqueda y fracaso?

${ }^{99}$ Hipatía de Alejandría, matemática y filósofa del siglo V, fue asesinada (torturada, incinerada) por razones religiosas o políticas, según diferentes versiones basadas en los escasos documentos sobre su vida. La identificación con Cesárea alcanza no obstante para abrir el abismo que aquí se anuncia y será plasmado en 2666: es el anuncio de las muertas del desierto de Santa Teresa que configurarán otro enclave en el topos bolañiano de la violencia latinoamericana. Ver Rodriguez Freire (2012: 160-161)
} 
persiguieron durante todo el trayecto. Una pelea con cuchillos y pistolas termina con la muerte de Alberto, el policía que lo secunda y Cesárea, quien sufre un disparo cuando intenta salvar a Ulises. El sinsentido que reviste su muerte salva a los dos poetas real visceralistas, y nuevamente la huida da lugar a una búsqueda que se emprende en la segunda sección.

En el marco de esta ficcionalización de la experiencia poética que se inicia en los años de la juventud mexicana, una nueva versión del tópico de la búsqueda del escritor se introduce para armar la gran metáfora que lo constituye como escritor integrante de una generación específica. La búsqueda de la fundadora del real visceralismo, de la madre emperatriz (Césarea) de la poesía se transforma en una aventura disparatada que termina con la muerte de la misma. Esta metáfora convierte a los poetas en huérfanos, perdidos en el desierto mexicano, no sólo porque mataron a Cesárea sino porque forman parte de la juventud sacrificada. Aquí, el tono humorístico y grotesco de una poeta vanguardista detrás de un puesto de ventas de hierbas conjuga el fracaso con el disparate.

La segunda parte de la novela ("Los detectives salvajes (1976-1996)") está conformada por noventa y seis testimonios de diferentes miembros del "movimiento" real visceralista, poetas, editores, profesores, amigos de los líderes del grupo, Lima y Belano, cuyas voces intentan reconstruir sus pasos a lo largo de treinta años. El panorama real visceralista en esta parte pretende dar cuenta del destino de sus fundadores pero termina siendo un recorrido voraz por la tradición literaria latinoamericana, en especial por las vanguardias y su sepultura (cifrada en el final de la novela con la muerte de Tinajero).

La novela historiza el recorrido por diferentes concepciones poéticas de América Latina $^{100}$ que se remonta a la vanguardia articulada con los procesos de modernización de los años veinte, se detiene en la vanguardia militante de los setenta en el fragor proyectado por la Revolución Cubana y culmina con el cuadro decadente que instala el mercado de los noventa. Asimismo se cuestionan ciertos nudos fuertes de la tradición latinoamericana como la figura de Octavio Paz o ciertas estéticas del boom. En la novela se concentran cuestiones nodales sobre las que Bolaño regresa de diferentes maneras: las potencialidades de la vanguardia y su universalismo, la experiencia de la revolución y el horror adyacente y el mercado con su nefasta incidencia en la literatura.

${ }^{100}$ La lectura de Andrea Cobas Carral y Verónica Garibotto (2008) plantea este recorrido. 
La relación con las vanguardias es compleja porque adquiere usos diversos y múltiples significados. En principio, el estridentismo mexicano aparece como un primer punto al que dirigirse para iniciar nuevos rumbos. El carácter específico del movimiento fundado por Manuel Maples Arce en 1921 debe su impronta a la órbita de la Revolución Mexicana. La actitud beligerante de Maples Arce, German List Arzubide y Arqueles Vela (quienes aparecen en la novela) se define como una estrategia que cruza la vanguardia política y la vanguardia estética a partir de la acción y la subversión. Los estridentistas rescatan el ritmo vertiginoso de la revolución (y la huella del futurismo) ${ }^{101}$ como una dinámica estrepitosa para dar el paso a la modernidad arremetiendo contra los “cisnes y las princesas". Los real visceralistas retornan a la actitud de los movimientos de vanguardia de los años veinte contra la tradición anterior y las instituciones, a lo que añaden la vitalidad contracultural de los beatniks. ${ }^{102}$ Octavio Paz encarna esa figura de autor ya instalado y anquilosado en la institución literaria que hay que atacar. Los real visceralistas, por ejemplo, irrumpen en encuentros o recitales de poesía a modo de comando terrorista, intimidando casi infantilmente a las figuras consagradas. La humorada se completa cuando Octavio Paz le cuenta a su secretaria: "un grupo de energúmenos de la extrema izquierda planearon secuéstrame” (507). Y como adenda: el encuentro de Paz con Ulises Lima en el Parque Hundido (narrado por la servicial secretaria de Paz) se reduce a una charla amable (jamás sabremos el contenido) en un banco de plaza. Una imagen parecida la conforman los poetas estridentistas ya entrados en años que han dejado atrás la rabia de la vanguardia y se han museificado. Los poetas "viejos", los consagrados, son quienes por un lado, desestiman al grupo pero por el otro, son quienes mejor lo definen. Manuel Maples Arce los califica de "huérfanos sin vocación" en su discurso algo senil (“en fin me pierdo ¿dónde estaba?” 116) que Bárbara Patterson retoma completando el cuadro que contrasta "los nuevos" con el “Gran poeta del Pleistoceno" (178). Carlos Monsiváis, más amable, no recuerda su encuentro con los poetas como violento sino antes bien como caprichoso e infantil. "Dos perdidos, dos extraviados" (160) sin argumentos y sobre todo sin dinero para pagar los cafés, el "lumpenismo" que Jacinto Requena reafirma (181).

La atmósfera de dislate juvenil que rodea al grupo también se extiende a la estructura de esta segunda parte que presenta un delirante manejo de información poco

\footnotetext{
${ }^{101}$ El futurista "Matemos al claro de luna" (Marinetti 1901) se transforma en el estridentista "Chopin a la silla eléctrica!” (Maples Arce 1921).

102 "Déjenlo todo. Láncense a los caminos" termina el Manifiesto infrarrealista, una amalgama desbordante entre Rimbaud y Kerouac.
} 
fiable en el sentido que no ofrece datos concretos ni precisos que echen luz sobre el real visceralismo y sus fundadores. Los testimonios recopilados -no sabemos por quién- son de diversa índole, están ordenados cronológicamente y atravesados por una voz que se repite: es el peculiar testimonio de Amadeo Salvatierra en 1976, bebiendo constantemente mezcal, contemporáneo a los estridentistas, quien conoce a Tinajero y posee el único ejemplar de Caborca, la revista dirigida por la poeta. Quienes aparecen como fuentes para ir recuperando los datos perdidos de los pasos de Arturo y Ulises a su vez están recordando entrevistas previas que tuvieron con los fundadores del real visceralismo, como Amadeo quien evoca el encuentro anterior a la aventura en busca de Tinajero. El espejeo de la situación enunciativa de alguien que entrevista a otro que fue entrevistado provoca un juego en espiral, una puesta en abismo de la noción misma de búsqueda que, como descubrimos en la tercera parte, conlleva el fracaso, la imposibilidad de conocer y se debe a que esta investigación detectivesca intenta fútilmente dar con la literatura. Otros testimonios se retoman mutuamente, como en diálogo, dando la sensación de que los entrevistados están juntos. Otros funcionan como relatos intercalados, donde la presencia de Belano o Lima es tangencial. Si se espera conocer los detalles y rasgos de movimiento real visceralista poca información rigurosa ofrece este aluvión de voces, aun bajo la apariencia de un trabajo minucioso de recopilación bioliteraria, con semejante cantidad de fuentes meticulosamente ordenadas y clasificadas con fecha y lugar.

Entonces, la recuperación de los testimonios, los datos biográficos, el archivo conformado a partir de notas y entrevistas constituyen una búsqueda detectivesca para dar cuenta del núcleo del movimiento vanguardista al cual, sin embargo, nunca se accede. No es posible llegar al verdadero núcleo de la literatura porque es lo que está siempre más allá, solo se queda en las anécdotas, en los recuerdos poco fiables. Nuevamente el tópico de la búsqueda del escritor conduce a un callejón sin salida.

La franja temporal de los setenta, de 1976 a 1979, recupera diferentes momentos de los jóvenes real visceralistas, algunos recuerdan a Belano (como Perla Avilés que evoca los años de "prepa" y las quejas de Belano a los dueños del Opus Dei -como ya leímos en el relato "La Colonia Lindavista"), otros tienen una visión más de grupo y remiten directamente al "movimiento". Con poco entusiasmo es recordado por Luis Rosado cuyo relato identifica al grupo como unos mafiosos. Rosado recuerda el primer encuentro con los jóvenes poetas quienes lo abordan en un bar, de manera intimidatoria, 
como si fueran matones, para "hablar de poesía". ${ }^{103}$ Otra vez, el disparate aparece en el sin sentido de la intimidación cuando se explica que los poetas concuerdan en un noventa por ciento con Rosado salvo que éste defiende a Octavio Paz, enemigo declarado del grupo.

$\mathrm{Si}$ bien los testimonios trazan algunas escenas de los real visceralistas y pareciera que se intenta definir al grupo, el centro hacia el que se apunta siempre es Arturo y Ulises. La actitud, que los define, de rebeldía o, como apunta con lucidez Joaquím Font internado en el manicomio, de desesperación (201) está asociada a la adolescencia (tienen entre veinte y veintitrés años) pero también se inscribe en una zona oscura de la que sólo se dan mínimos indicios, rasgos e impresiones que los coloca en un fondo negro amenazante.

Esta zona fundamental que se va armando en los testimonios es aquella que configura el telón de fondo de la historia intelectual que la autoficción proyecta. El momento clave es el regreso de Belano a Chile, en el tan evocado relato de su vuelta al país natal para apoyar el proyecto de la Unidad Popular donde se choca con el Golpe de la Junta Militar. Auxilio Lacouture llama la atención sobre el cambio que "Arturito" Belano acusa al regresar de Chile luego del Golpe de Pinochet: la conocida anécdota del viaje a comprometerse con el triunfo de Salvador Allende, con el entusiasmo interrumpido por la dictadura militar, la detención de Belano y la vuelta a México. Para Auxilio, a partir de allí Belano es otro, es como Dante que mira todo como si hubiera vuelto del infierno (196). Es entonces cuando conoce a Lima y proyectan revolucionar la poesía mexicana (la jerga que los separa de Auxilio, quien no comprende de qué hablan, es el glíglico. No sólo en claro homenaje a Rayuela, el dato apunta la burbuja de incomprensión con la que se construye el grupo y nadie romperá). Puede delinearse entonces la cadena de acontecimientos que arman el relato intelectual de Belano desde el real visceralismo mexicano al "exilio" en España. El regreso desde Chile a México después de la experiencia con la dictadura de Pinochet es clave (la escena de la detención en Chile es otra motivo que insiste en renarrarse) porque es entonces cuando funda el real visceralismo para lo cual debe encontrar (y matar) a la madre de la poesía. Esta aventura atravesada por el disparate también encierra el gesto vanguardista de exterminar lo sublime de la poesía (nada más alejado de lo sublime que la figura de

\footnotetext{
103 "De improviso esos tres energúmenos me rodean, se sientan uno a cada lado y me dicen Luisito, vamos a hablar de poesía (...) yo no soy una persona violenta y por supuesto me puse nervioso. Pensé: qué hacen aquí, cómo han dado conmigo, qué cuentas vienen a saldar". (153)
} 
Césarea en el desierto mexicano). Pero carece del optimismo revolucionario del estridentismo o del surrealismo porque el lugar que ocupan los real visceralistas está oscurecido por las derrotas de las utopías latinoamericanas.

La juventud castrada/sacrificada aparece también en el recuerdo de un poema de Arthur Rimbaud (155) que Ulises recita en francés y que el poeta mexicano relaciona con la guerra. Esta historia del poema que según Ulises el poeta francés escribe para purgar los sufrimientos de una violación que lo tiene como víctima cuando iba a París a unirse a la Comuna, aparecerá en diferentes partes de la novela. La historia completa resurge en Los sinsabores del perfecto policía (137-141) y aquí en Los detectives salvajes es contada por Alberto Moore, quien retoma el relato de Rosado, y también es mencionada por García Madero en la tercera parte (601). Es Amalfitano en Los sinsabores del verdadero policía quien da la reflexión final, como cerrando la posta de alusiones: "todo estaba claro (...) el poeta adolescente degradado por la soldadesca justo cuando se dirigía ¡a pie! al encuentro con la Quimera" (138). Esta imagen describe a una generación latinoamericana de jóvenes homenajeados insistentemente en la obra de Bolaño, en Los detectives salvajes, en el final de Amuleto, por ejemplo, en el camino que une la poesía con la lucha, la utopía y el horror. ${ }^{104}$

La década del ochenta indagará en los recorridos políticos de los real visceralistas, especialmente a partir de Ulises. El humor evita endilgarles un compromiso político-ideológico que los coloque en un lugar sublime ni épico. Al respecto, Alfonso Perez Camarga es terminante: "No eran revolucionarios. No eran escritores. A veces escribían poesía, pero tampoco creo que fueran poetas. Eran vendedores de droga" (329) “... aunque su apariencia pretendiera amoldarse al arquetipo tan manido del joven poeta de izquierda (330). Cuando Ulises y Arturo conocen a Verónica Volcow ni siquiera le preguntan por su bisabuelo León Trotsky sino por la poesía, recuerda la misma Volkow entre aliviada, decepcionada y horrorizada por la apariencia de mendigos y la posibilidad de tener amigos en común (327). Ese momento fue lo más cerca que estuvieron del Partido Bolchevique, había sentenciado José Colina en el testimonio anterior (326).

\footnotetext{
104 La misma historia emerge en diferentes páginas y en diferentes textos. También manifiesta la insistente conexión que une Europa con América. Aquí el dato es que el soldado que violó a Rimbaud es veterano de la invasión fracasada de las tropas francesas (Maximiliano y Napoleón III) en México. Es en Villaviciosa (cerca de Santa Teresa) donde uno de los últimos reductos del ejército francés vencido (torturado, fusilado) por indios descalzos en medio del desierto da por finalizado los proyectos del emperador. Logran sobrevivir y escapar unos pocos quienes regresan a Francia.
} 
El relato de Hugo Montero de alguna manera resguarda la autonomía del arte contra la parafernalia institucional de la revolución. La burla y la sorna de las escenas que la delegación de escritores comprometidos con la revolución sandinista presenta no es fulminante (sobre todo a partir de la figura de Montesol) sino que está matizada también por el homenaje. Ulises Lima viaja con el grupo y se pierde en Managua. Mientras tanto, la delegación realiza todas las actividades de rigor: se encuentra con Ernesto Cardenal, concurre a mesas redondas, recitales, eventos intelectuales y comprometidos pero Lima no aparece por ningún lado. La impostura del intelectual cae de lleno en la ironía cuando, por ejemplo, el nivel etílico de la delegación aumenta en el transcurso del viaje o Montero se queja sobre las bebidas más o menos decentes en Managua donde la mayoría de los bares sirven veneno puro "y yo no sé qué esperan los sandinistas para hacer algo al respecto" (334).

La crítica a las poses del intelectual institucionalizado de la revolución en la voz de Montero parece un pase de comedia. El guatemalteco Pancracio Montesol es el único que ha advertido a Lima y recuerda haberlo visto sólo los dos primeros días. Montesol (Monterroso) viaja con la delegación mexicana no sólo porque hace más de treinta años que vive en México sino porque no existe una delegación guatemalteca y de paso reivindica a Alfonso Reyes luego de pegarle a Octavio Paz. La actitud del amigable Monstesol es abierta y sin pompas, pide otro escocés total paga la Secretaría de Educación (336). Mientras que el resto, bajo el mando de Álamo, decide reunirse para el recuento antes de regresar (o para hacer un últimos brindis al sol, se sincera Montero, 336) y convocar una reunión para tratar el tema Lima (e intentar evitar que trascienda la desaparición de un poeta mexicano en Nicaragua), el poeta campesino Julio Labarca decide dar aviso a la policía, y "compañero por aquí, compañero por acá” (338) pero al final nadie se hizo mucho cargo de Lima pues pocos lo conocían, menos lo apreciaban. La preocupación se extiende al lugar vacante que había ocupado el real visceralista ¿cómo un poeta no quiso solidarizarse con la revolución? pregunta un inspector, fumador sólo de cigarros cubanos, puros de verdad, fuertes, los que fuman los revolucionarios (339). Esto desencadena una rídicula escena donde Labarca y el inspector discuten por el tabaco mexicano (los Delicados, rubios y dulces) y el cubano (fuerte y negro). Una escena delirante que cierra con Pancracio Montesol contando una anécdota sobre poetas perdidos que nunca mueren que le contó Monteforte Toledo a quien Montero confunde con Miguel Angel Asturias. Conclusión: Lima regresa a México después de dos años de recorrer la miseria y pobreza centroamericana. 
Otra instancia donde la crítica se cierne sobre los dogmas de la revolución latinoamericana y critica las instancias de consagración de los aparatos de la revolución la cuenta Fabio Logiacomo, el argentino censurado por Casa de las Américas pero contento con el premio otorgado a su poemario, mutilado debido a una pieza sobre Daniel Cohn Bendit, a quien el jurado consideró contrarrevolucionario y a lo que Ulises Lima reacciona: "qué hijos de puta" (152). Figurando el desarraigo del exilio, el recorrido de Lima y Belano los llevará a París- Tel Aviv y África- Barcelona respectivamente. Lima entrevista a Michel Bulteau y le cuenta la historia que el lector conoce: "una historia de poetas perdidos y de revistas perdidas y de obras sobre cuya existencia nadie conocía una palabra, en medio de un paisaje que acaso fuera el de California o el de Arizona o el de alguna región mexicana limítrofe con esos estados (...) en los extramuros de la civilización" (240). Belano es vigilante nocturno de un camping (Mary Watson, quien no nombra a Belano como tal sino que se refiere al "vigilante nocturno" relata su historia con la insistencia en el peligro, en que algo mal pasa (254-5)). Los viajes vuelven a hilvanar los tópicos y motivos que instalan el peligro y la violencia como ejes de la juventud sacrificada. Los últimos pasos de Belano serán en África, en las guerras civiles de países lejanos. Allí conoce a Jacobo Urenda, un periodista argentino quien supone que a los latinoamericanos el horror no impresiona tanto como los demás (526) y nuevamente se actualizar el tópico de la juventud sacrificada desde la perspectiva con la que Belano interpreta la realidad en Liberia: todos los soldados de la guerrilla africana "son jodidamente jóvenes (...) y se matan como si estuvieran jugando" (547).

Las figuras de Belano y Lima se vuelven más difusas a medida que avanza la cronología de los testimonios, que parecen relatos intercalados para alejarse de los setenta e ingresar en la década del noventa. Como el del abogado Lendoiro, fanático de las citas en latín, que articula dinero (sucio), poesía y enfermedad. O los de Susana Puig y Jaume Planells, dos versiones del duelo con espadas que Belano sostiene con el crítico literario Iñaki Echavarne, el escritor y el crítico en una lucha épica para salvar el honor (basado en una confusión) a través de un "dale que te pego, dale que te pego, como dos niños tontos" (483).

Con este preludio, la década los noventa tiene su epicentro en la Feria del Libro de Madrid en 1994, desde donde ochos representantes de las letras contemporáneas dan su visión de la historia (de la historia literaria, con la muletilla final que rehace la frase de Karl Marx sobre las repeticiones de la historia - primero como tragedia, luego como 
farsa) sin siquiera mencionar a Belano y Lima. Echavarne sentencia la imposibilidad de una obra eterna, pues primero mueren los críticos, luego los lectores y finalmente la obra (lo que empieza en comedia acaba como tragedia), de los autores no habla pero lo harán ellos en primera persona. El eje será el paso de la transgresión, la reforma y la revolución al asentamiento, la tranquilidad y la escala en la pirámide social (485) cuyo atributo es la falta de valor que posibilita una vida serena (484). Sobre el honor de los poetas, Julio Martínez Morales disemina un discurso interrumpido por ejercicios criptográficos $\sin$ sentido (" $7 \times 1=8$ ", “ido $\times$ ido=una cárcel en el cielo de la literatura. Deambulo. Deambulo" 486), una prosa hermética que sin embargo se sincera en momentos de lucidez textual: “¿cómo no se dan cuenta los jóvenes, los lectores por antonomasia, de que somos unos mentirosos?". Y la impostura, la falsedad, el conformismo y la condescendencia también configurarán la red que aglutine el oficio literario de estos escritores profesionales (mil ejemplares en un día de La nueva era y la escalera ibérica vendió García León, a medio camino entre gurú y escritor, en la Feria), "escritores-presentadores de televisión" (496) y los nuevos raros inundados de ansiolíticos y antidepresivos.

Este escenario que se abre con la entrada de lleno al mercado trasnacional del neoliberalismo constituye otra zona difícil para el escritor porque precisamente lo que se pierde aquí es lo literario, nuevamente la búsqueda que es necesario emprender debe apuntar a la literatura. El penúltimo testimonio es el del profesor García Grajales de la Universidad de Pachuca, experto en el movimiento real visceralista ("el principal estudioso, la fuente más autorizada", 550) pero nada agrega, tan solo breves datos sobre los destinos de algunos personajes, en los que no se incluye a García Madero pues no lo conoce. Es la figura del crítico experto de los noventa, que recopila copiosamente sus fuentes documentales (revistas, panfletos), sus joyas inhallables y está convencido de que su "librito" sobre el movimiento traerá la modernidad a la universidad. La academia entonces es otra forma de mercado (y donde Bolaño entrará de lleno en "Las parte de los críticos" de 2666). Sin embargo, no hay una visión que cristalice al mercado como un entre monstruoso que cercena las libertades del escritor. Al contrario, los escritores en la Feria del Libro de Madrid parecen satisfechos con sus ventas y sus seguidores. La cuestión del valor literario (con cuantiosas páginas escritas al respecto) ${ }^{105}$ es el nudo que

\footnotetext{
${ }^{105}$ Un interesante estado de la cuestión en el ámbito argentino, pero que se abre a otras latitudes, puede encontrarse en el Dossier "Cuestiones de valor", a cargo de Álvaro Fernández Bravo del Boletín/ 15
} 
hay que desentrañar y Bolaño no fija ninguna entrada sino que complejiza el terreno a partir de diferentes vías de aproximación.

Siguiendo el recorrido que emprende Bolaño en la novela, podemos ubicar la problematización de los vínculos entre literatura y mercado en los postulados vanguardistas que, como han sido analizados por sus teóricos más reconocidos (Bürger, Sanguinetti), paulatinamente pierden vigor en el momento en que las obras ingresan en la lógica mercantil de los bienes simbólicos, a las casas editoras, galerías, academias, museos. La institución degrada, como sucede con los estridentistas, Octavio Paz y los poetas comprometidos con la revolución (a quienes no les importa la censura siempre y cuando obtengan el premio). Aquí, Bolaño opone una imagen opuesta que funciona más como ideal que como programa: Cesárea en el desierto mexicano, lejos de todo marco institucional. ${ }^{106}$ Otro momento cardinal de la historia literaria (latinoamericana) en relación con el mercado es el del boom que Bolaño recupera (veremos esto con atención en los capítulos siguientes) no para denostar a los epígonos de las décadas anteriores sino a las versiones desinfladas que les sucedieron. Así lo explicita en el ensayo ya citado, "Los mitos de Chtulhu":

“En realidad la literatura latinoamericana no es Borges ni Macedonio Fernández ni Onetti ni Bioy ni Cortázar ni Rulfo ni Revueltas ni siquiera el dueto de machos ancianos formado por García Márquez y Vargas Llosa. La literatura latinoamericana es Isabel Allende, Luis Sepúlveda, Ángeles Mastretta, Sergio Ramírez, Tomás Eloy Martínez, un tal Aguilar Camín o Comín y muchos otros nombre ilustres que en este momento no recuerdo" (170)

El blanco al que apuntar está en los proyectos del escritor, sus figuraciones en el campo, de modo que el problema no es el mercado si se constituye como industria cultural, para decirlo mejor con Ángel Rama, pues la literatura es además un trabajo, como insistió Roberto Arlt en el clásico prólogo a Los lanzallamas. Bolaño lee el boom en perspectiva y se corre del modo fácil de estigmatizarlo con el descalificativo del

editado por el Centro de Estudios de Teoría y Crítica Literaria de la Universidad Nacional de Rosario (2010).

106 Otro perfil de esta cuestión es Archimboldi, quien no se sabe dónde está: la ausencia del escritor refiere una no pertenencia simbólica pues en realidad él es un escritor consagrado y exitoso (los tiempos de Césarea y Archimboldi son diferentes. Porque si Tinajero muere, sus discípulos continúan con su legado marginal, pero a Benno nunca accedemos más que por terceros y por su obra que prolifera casi a escalas industriales). 
éxito o del estereotipo. El poder de la institución - política, económica, académica- no aplasta la literatura si pueden abrirse brechas, resquicios por donde se filtran las potencialidades críticas del escritor. Por ello Bolaño apuesta todavía a una fuerte presencia del mito de autor, aun cuando su figura se nos escape y solo permanezca una huella. Y calibra la mira para disparar contra los esbozos de autor que se pierden en la superficie.

En este sentido, hay un relato que adquiere diversas versiones y presencias en el Hipertexto-Bolaño que tiene que ver con ese linaje latinoamericano con el que discute en términos absolutamente lúcidos que es el del boom. La historia de las mujeres Expósito aparece en Los detectives salvajes, 2666 y Los sinsabores del verdadero policía. El relato narra las cerca de ocho generaciones de las Expósito de Villaviciosa que comienzan en 1865 con la violación de una huérfana de trece años por un soldado belga. A partir de entonces se conformará un linaje desquiciado de Marías Expósito violentadas, ultrajadas y abandonadas por los hombres. El rasgo que las atraviesa es la magia, la curandería y los ungüentos medicinales. En la quinta generación de las Expósito, en 1917, Rafael, el primer varón, nace en las convulsiones de la revolución mexicana y un detalle lo marca fatalmente: tiene la mirada opaca e intensa de los asesinos (Los sinsabores, 239). Será el encargado de vengar el ultraje contra su hermana María Expósito y terminará ajusticiado en una fosa común de Santa Teresa. No queda lugar en esta familia para José Arcadios ni Aurelianos de modo que esta sucesión macabra de mujeres violentadas no sólo anuncia los asesinatos de las mujeres de Santa Teresa (2666) sino que constituye una ruptura irreverente (de atrocidad y sorna) con la tradición anterior. Al mismo tiempo -además del velado homenaje crítico al realismo mágico- la puesta en abismo de la sucesión excesiva de "Marías" figura la copia que imita una fórmula consagrada. ${ }^{107}$ Este motivo que activa el espiral del eterno retorno se detiene en la versión de 2666. Aquí, el último de los Expósito es Olegario Cura Expósito, también conocido como Lalo. De modo que este desquiciado linaje basado en la violencia sexual de mujeres mágicas termina nada menos que con la locura (Lalo Cura).

\footnotetext{
${ }^{107}$ Resuena un poco tal vez el eco de las Trueba-Del Valle, las mujeres clarividentes de La casa de los espiritus, de Isabel Allende, cuyo linaje (en la hacienda Las Tres Marías) está fundado por la genealogía patriarcal del macho latinoamericano.
} 


\section{LA MEMORIA EN LA TENSIÓN ENTRE TESTIMONIO Y FICCIÓN}

El uso de las escrituras del yo como vehiculización de la cuestión de la memoria, núcleo destacado de la narrativa de Bolaño será trabajado en este capítulo desde Nocturno de Chile, donde la tradición de la confesión enmarca los dobleces del recuerdo, el silencio y la culpa.

\section{1. Testimonio y confesión. Literatura, melancolía y posdictadura (Nocturno de Chile)}

He aqui mi memoria y sus largos espacios, sus antros, sus cavernas innumerables, llenas de innumerables especies de cosas innumerables, que están ahí, sea por imágenes, como los cuerpos todos, sea por presencia real, como las ciencias, sea por no sé qué nociones o notaciones, como las impresiones del espíritu, las retiene la memoria, pues todo lo que está en ella está en el espíritu. Voy pasando por todo esto, revoloteando acá, allá; voy penetrando tan adentro como puedo, y no hallo límite en parte alguna, jtan grande es el poder de la memoria!

San Agustín, Confesiones, Cap. XVII, Libro X.

Revisitar la memoria en torno a la última dictadura militar en Chile se vuelve necesario desde una perspectiva que evite clausurar dicho acontecimiento como 'histórico': la 'memoria' como el intento de profundizar en los hechos que aún generan resquemores en la sociedad, que explicitan debates y posturas antagónicas, desde un presente que exige revisar un pasado como 'herida que no cerró', como dilema que persiste. Por lo tanto, su temporalidad es tanto la del pasado como la del presente. ${ }^{108} \mathrm{La}$

\footnotetext{
${ }^{108}$ Como señala Reyes Mate: “(...) lo propio, por tanto, de la mirada de la memoria es, en primer lugar, la atención al pasado ausente del presente y, en segundo, considerar esos fracasos o víctimas no como datos naturales que están ahí como están los ríos o las montañas, sino como una injusticia, como una frustración violenta de su proyecto de vida (...) Pinochet, por ejemplo, no es la única realidad después de la derrota de Allende. Pinochet es lo fáctico pero si queremos comprender la realidad de los años de Pinochet tenemos
} 
cuestión de la memoria, siguiendo a Henry Rousso, exige ver cómo, en un momento dado, la sociedad enfrenta el pasado y utiliza, explícita o implícitamente, esa relación pasado/presente de diferentes maneras -morales, políticas, etc.- para escribir la historia.

En este marco, proponemos una lectura de Nocturno de Chile ${ }^{109}$ que articula el par duelo / melancolía en relación con el problema de la memoria en el Chile de la dictadura y la posdictadura. La melancolía, entonces, como posibilidad estética encarnada en la percepción desengañada de coyunturas históricas y relatos de la Historia, como visión de mundo signada por las caídas en el fin de siglo / fin de la dictadura. Al explorar los diferentes significados de la melancolía, como metáfora central del texto, se iluminan los hilos de una trama sincopada que narra el reverso de una literatura optimista o de tintes heroicos, que pauta el fracaso de los grandes relatos, y que nos entrega como símbolos del presente: el nocturno, la melancolía y el crepúsculo. En Nocturno de Chile la melancolía articula, entonces, dos zonas de indagación: el problema de la memoria/ amnesia y el lugar del escritor frente a lo sucedido, cómo y desde dónde narrar el horror. La melancolía como dislocación y como fractura contamina sujetos, espacios y modos de ver.

\section{El escritor y la fractura de la memoria}

Antes de la imagen de la melancolía como metáfora axial de las pérdidas y fracasos, aparece en esta novela un primer significado de la melancolía vinculada al narrador protagonista, Sebastián Urrutia. En la visión psicoanalítica, la melancolía indica una disposición enfermiza, trágica y asociada al sentimiento de la pérdida. Sigmund Freud la define como un "conflicto en el interior del yo", que, a modo de "herida dolorosa" ([1917] 2000: 255), evidencia una crisis identitaria a partir de una pérdida: el sujeto queda atrapado en la melancolía al no poder tramitar el duelo. El duelo se configura así como un proceso cerrado y sano frente al estadio melancólico que supone la herida abierta que no puede clausurar el vínculo con lo perdido. En el cura Urrutia la melancolía refiere a una herida que el recuerdo abre pero se convierte en culpa ante la presencia de la complicidad.

que tener en cuenta la presencia de la ausencia de Allende, es decir, la sustracción a la sociedad chilena de una experiencia política abortada violentamente" (2006: 45-46).

${ }^{109}$ Bolaño, Roberto, Nocturno de Chile, Barcelona, Anagrama, 2000. Todas las citas pertenecen a esta edición, se indicará número de páginas entre paréntesis. 
Sebastián Urrutia Lacroix, un sacerdote opusdeísta, poeta, crítico literario y profesor, en una noche de fiebre -ya en democracia- comienza a recordar escenas de su pasado, algunas de las cuales permanecían ocultas, arrinconadas en su interior por la culpa de haber participado y colaborado con la dictadura, como por ejemplo, en las clases de marxismo que da a miembros de la Junta Militar pinochetista. Es en esta tensión entre el recuerdo que pugna por salir, y la culpa que incita al silencio, cuando aparece la voz del "joven envejecido" como signo de esta fractura, como índice de una subjetividad escindida.

El "joven envejecido", más que un sujeto siempre presente, es una voz siempre constante en el texto que vigila el relato de Sebastián, que intercepta su confesión para culparlo, para desmentirlo, para acusarlo, para impedir los olvidos y las tretas con las cuales el narrador procura justificarse: "Y rebuscaré en el rincón de los recuerdos aquellos actos que me justifican y que por lo tanto desdicen las infamias que el joven envejecido ha esparcido en mi descrédito en una sola noche relampagueante" (11). Este joven envejecido es un escritor que "a finales de la década del cincuenta (...) sólo debía tener cinco años, tal vez seis, y estaba lejos del terror, de la invectiva, de la persecución" (22); estos datos parecen apuntar a la propia biografía de Bolaño, o a la de toda una generación que busca una justificación e intenta un ajuste de cuentas que deviene imposible.

Sin embargo, no hay en el texto la posibilidad de fijar sentidos totales, de cercar identidades 'transparentes' y esta voz, que es la del joven envejecido, también es el cura en el último tramo de su delirio: “¿soy yo el joven envejecido? ¿Esto es el verdadero, el gran terror, ser el joven envejecido que grita sin que nadie lo escuche?" (149) se pregunta. Es la propia conciencia -o es la voz del otro- que, a pesar del silencio y el paso del tiempo, se instaló en la memoria. Así, el repaso de Sebastián evidencia una lucha constante entre lo que la conciencia decide traer al presente y lo que el recuerdo oculta, entre la memoria y el olvido.

Esta fractura de la memoria también se exterioriza cuando el cura se enfrenta con el "otro", (además del joven envejecido) como los campesinos o los niños, alteridades que provocan reacciones de delirio febril y quiebran el continuum del relato, en apariencia ordenado por la razón. Sebastián asiste a los banquetes que el crítico literario Farewell ofrece en su finca. En dos ocasiones, el cura recorre el exterior del fundo Là Bas y se encuentra con los campesinos y con los niños que generan "miedo y asco" (20) en tanto parte de un 'afuera' irreducible, inclasificable y caótico. El sacerdote 
no comprende sus acciones, su discurso se vuelve dubitativo, repetitivo en imágenes, interrogador, dice: "consiguieron alterar mi equilibrio mental y físico” (30); “(...) todos eran feos. Las campesinas eran feas y sus palabras incoherentes. El campesino era feo y su inmovilidad incoherente. Los campesinos que se alejaban eran feos y su singladura en zigzag incoherente." (30) Como anti-tipo de estos sujetos -dentro del juego de espejos que despliega la novela- aparece el niño Sebastián, el hijo de María Canales, cuyos ojos azules 'ven lo que quieren ver' y provocan ganas de llorar en el cura. Son símbolos de lo puro, de lo inocente que colisiona con la oscuridad turbulenta de su conciencia. Estas oposiciones entre lo impuro y lo puro, lo sucio y lo limpio, lo culpable y lo inocente, es aquello que la novela va a impugnar para invertir sus signos o mostrar sus dobleces.

En varias ocasiones -diseminadas por toda la novela- el cura aparece encerrado en el silencio, incapaz de abrirse al recuerdo: "estaba en paz conmigo mismo. Mudo y en paz" (11); “el miedo de oír aquello que no se puede oír, las palabras esenciales que no podemos escuchar y que con casi toda probabilidad no se pueden pronunciar" (34); el vallejiano "quiero decir pero sólo me sale espuma" (64), "qué agradable resulta no oír nada, y no tener memoria” (71); “toda conversación, todo diálogo, decía una voz, está vedado" (35), sobre el tiempo y el olvido: "los pozos ciegos de la memoria" (47); "los pliegues fantasmagóricos del tiempo" (70), "el ligero espasmo del tiempo y las demoliciones” (69); “¿para qué remover lo que el tiempo piadosamente oculta?” (142); “en el túnel del tiempo, en la gran máquina de moler carne del tiempo" (147).

Sin embargo, no hay alivio posible frente al quiebre de una identidad en constante lucha entre el pasado y el presente. El relato de la memoria debe asumir las señales históricas de una coyuntura definida como "pérdida de la palabra, suspensión traumada del habla" (Richard 2003: 287) que moldeó cierta "memoria común y muchos olvidos compartidos" (Groppo 2001: 17). En consecuencia, la melancolía surge como instancia crítica del yo que se origina desde la conciencia culposa y que recupera el recuerdo de la pérdida, de la memoria de lo sucedido pero desde el lugar del colaborador. De allí el carácter culposo de esta melancolía. Siguiendo lo anterior, el mismo Bolaño, en una entrevista para La Nación, define la novela en estos términos: "un intento fallido de amnesia donde todos somos iguales, las sombras inocentes y los brutos malévolos, los personajes reales y ficticios, es decir, todos somos víctimas, solo que de una forma indolora" y "trata sobre el efecto del tiempo en las historias, sobre el 
lento progreso del olvido que es una de las formas de la ocultación hacia la que con más gusto y puede que con más justificación tendemos" (Bolaño 2001).

Se evidencia, así, una textualidad que en clave de Bildungsroman (y más cerca aun de la Künstlerroman) intenta el repaso de la vida para suturar la identidad escindida; un relato que oscila entre la confesión religiosa del sacerdote y el discurrir psicoanalítico para que el yo recupere la memoria y pueda tramitar su culpa melancólica.

\section{El escritor y la complicidad con el silencio}

El juego entre la memoria y el olvido se vehiculiza en el tratamiento de la espacialidad para delatar las zonas que la apariencia quiere ocultar, así como los centros clandestinos de tortura intentaban camuflarse en los espacios de una ciudad militarizada.

La dictadura construyó sus propios espacios, en su mayoría ocultos y clandestinos, separados de la cotidianidad. Giorgio Agambem define el campo de concentración como un estado de excepción, caracterizado por la suspensión del derecho y del ordenamiento normal. ${ }^{110}$ Sin embargo, estos espacios específicos y ocultos que la dictadura instaura, invaden los lugares cotidianos y comunes, contaminan el ritmo de lo normal, se solapan en lo conocido. De este modo los espacios urbanos adquieren una lógica siniestra, todo lugar puede resultar sospechoso o cómplice. Esta nueva disposición espacial puede ser un centro clandestino de detención, el sótano de una casa, la ciudad entera.

Pilar Calveiro analiza los campos de concentración, en la última dictadura en Argentina, como zonas específicas que terminan contaminado la lógica social bajo el sistema represivo. Los campos de concentración no están apartados y alejados del orden social, por el contrario, su trama configura un entretejido con la sociedad que no es ajena a las prácticas del poder totalitario. La tesis que desarrolla Calveiro nos sirve para pensar los espacios en dictadura en relación con los diferentes registros de complicidad social. Expresa la autora: "Nadie puede permanecer en él 'puro' o intocado; de ahí la falsedad de muchas versiones heroicas. [...] En el mundo de los campos nadie puede atribuirse la inocencia pura ni la culpabilidad absoluta" (2004: 159).

\footnotetext{
110 “(...) un lugar aparentemente anodino (...) delimita en realidad un espacio en el que el ordenamiento normal se suspende de hecho y, en el cual, que se cometan o no atrocidades no depende del derecho, sino sólo de la civilización y del sentido ético de la policía que actúa provisionalmente como soberana" (Agambem 1995)
} 
En Nocturno de Chile, si bien no aparece el campo de concentración, sus características invaden los espacios representados que develan al Chile de la dictadura como un gran campo donde los límites entre víctimas y victimarios se vuelven difusos, como una gran zona gris ${ }^{11}$ en donde parálisis o complicidad denuncian una sociedad signada por la oscuridad, el silencio y la inmovilidad. ${ }^{112}$

Dos sitios, el fundo La Bàs de Farewell y la casa de María Canales, funcionan como estos espacios de doble fondo, lugares ambiguos que por un lado se presentan como normales y cotidianos, y por el otro pueden ocultar su complicidad con la arquitectura del terrorismo de estado. Son dos lugares del arte, representados como esferas ajenas a lo político, donde ocurren episodios que denotan el horror: el fundo frecuentado por el selecto grupo letrado del país y la casa de las veladas artísticas como metáforas del Chile infernal de la dictadura militar. Entonces, Bolaño elige estos espacios de la cultura y del arte para introducirnos en el terrorismo de Estado. Así, se trazan dos topologías que dan cuenta de los diversos grados de complicidad y responsabilidad de la ciudadanía: el fundo La Bàs y la casa de María Canales. En ellos, es la ciudad letrada la que aparece cuestionada, junto con otro importante sector: el eclesiástico.

Al comienzo, Là Bas se caracteriza como espacio de la cultura, un castillo alejado de la ciudad, cerrado, que corporiza el distanciamiento torremarfilista entre arte y vida (en Là Bas la referencia a Huysmans es explícita) y que denuncia el espacio externo como barbarie. Sin embargo, la imputación cambia paradójicamente de signo con la presencia de marcas simbólicas que relacionan -a modo de antecedente que prefigura- ese espacio cerrado con la dictadura.

En primer lugar, el ingreso al fundo Là Bas como refugio de la cultura, en un Chile pre-dictatorial, inculto, "país de bárbaros", aparece como un descenso a los infiernos, formando parte de una etapa iniciática en la conversión del cura Urrutia Lacroix en el crítico literario Ibacache, "Como si aquel carricoche fuera a buscar a alguien para llevarlo al infierno" (18). Además, la sala principal "se asemejaba a una biblioteca y a un pabellón de caza, con muchas estanterías llenas de enciclopedias y diccionarios (...) amén de por lo menos una docena de cabezas disecadas” (19). Por otro lado, cada paseo por las afueras del fundo se describe en términos de extravío, de

\footnotetext{
${ }^{111}$ El concepto es de Primo Levi (1995). Ver también Vezzetti, Hugo (2000: 13-17)

${ }^{112}$ Con estos tres últimos sustantivos describe Calveiro al campo de concentración (2004: 48)
} 
contaminación: la naturaleza salvaje, la presencia del otro -como ya se mencionógeneran miedo y asco.

Hay en Là Bas la confrontación de dos espacios -uno, desestabilizador; el otro, reconfortante y estable- cuyos límites, sin embargo, se tornan difusos; por momentos lo seguro se vuelve confuso. Luego de uno de los paseos del cura por las afueras de Là Bas, donde comparte el pan duro de los campesinos, "manjar ambrosiano, deleitable fruto de la patria, buen sustento de nuestros esforzados labriegos" (22), se describe una cena, a modo de gran banquete, con importantes invitados -Pablo Neruda, entre ellos. Esta escena, al sacerdote le produce nauseas, se siente enfermo y su discurso incurre en el delirio y la incoherencia vertiginosa: una escena con Farewell que delata sus inclinaciones homosexuales, un 'diálogo de locos' con Neruda, escenas que descolocan al cura quien, no obstante, expresa: "y recuerdo que en aquel momento yo tuve conciencia de mi miedo, aunque preferí seguir mirando la luna” (26).

El pan de los campesinos frente al banquete de la élite intelectual configura la imagen de la dislocación social a través de una serie de oposiciones (pan duro/ baquete; afuera/adentro; cultura/barbarie) que prefiguran la simultaneidad espacial que tendrán la sala de tertulias y el sótano del horror bajo el mismo techo de la casa de María Canales. Allí, se describe el final de las reuniones de la siguiente manera: "uno de nosotros previamente se había encargado de abrir el portón de hierro, y María Canales seguía en pie en el porche hasta que el último auto trasponía los límites de su casa, los límites de su castillo hospitalario" (128, cursivas nuestras), detalles que remiten al fundo de Farewell, que aparece, así, como prefiguración del Chile de la dictadura.

La casa de María Canales también posee una estructura interna dual. La simultaneidad de las tertulias literarias con la sala de tortura denuncia un Chile 'de superficie' y otro 'de sótano' e indaga acerca de las complicidades silenciosas -hasta inconscientes- con el régimen militar. De igual forma, demuestra cómo el refugio que ofrece el espacio de la casa de Canales no es más que una ilusión. Aquí, el círculo intelectual no está conformado por aristócratas torremarfilistas, pues las tertulias reunían a un número de "intelectuales dispuestos a crear de la nada (...) la nueva escena chilena" (129, cursivas nuestras): un poeta desesperado, una novelista feminista, un pintor de vanguardia hablan de literatura mientras el sótano funciona como sala de tortura. 
Patricia Espinosa señala que puede leerse "un calco casi exacto entre el poder político y el poder crítico. Este espejeo, sumado a las tertulias en la casa de María Canales, en cuyos subterráneos se practicaba la tortura, tiende a abrir una brecha culposa en la moralidad del establishment artístico nacional” (2002: 131). Es necesario preguntarnos acerca de ese "establishment artístico nacional" que Bolaño está poniendo en cuestión. No sólo involucra a los sectores intelectuales afines a la dictadura sino que se abre a un espectro más amplio de artistas. Incluso podríamos sospechar que, provocativamente, hay una referencia a la hipervanguardia, que -como se mencionó anteriormente- reunió a un grupo de artistas quienes durante el gobierno de Pinochet constituyeron lo que Nelly Richard denominó 'el polo victimado', como escena cultural alternativa y crítica de la crisis dictatorial. Esa dualidad representada en la casa de María Canales socava toda posibilidad real de resistencia o crítica, con lo que Bolaño interpela -sin reparos- al sector vanguardista del campo intelectual por algún grado de complicidad consciente o inconsciente, o al menos silencio, con las políticas del terrorismo de Estado. ${ }^{113}$

Una vez terminada la dictadura, se dan cuatro versiones del episodio de la tortura; cada una agrega nuevos datos como parte de un proceso de recuperación de la memoria que crece con la apertura democrática -en un despliegue de sucesos, de información que devela y obstruye, avanza y se paraliza. El cura se encuentra con un “joven novelista de izquierda" quien niega repetidas veces haber conocido a María Canales o participado de las reuniones y nos retrotrae al momento en que el cura prefirió mirar la luna en $L a ̀$ Bas, sin hacerse cargo de un contexto agobiante. Si, en un primer momento, el foco está puesto en la élite literaria, opusdeísta, pasando aún por el mismo Neruda, aquí la sospecha involucra a los escritores más progresistas de la escena chilena. Al respecto, Hugo Vezzetti expresa que "una sociedad debería hacerse cargo no sólo por lo que activamente promovió y apoyó sino incluso por aquello que fue incapaz de evitar" (2002: 41).

Así, el círculo aislado de La Bàs, y luego las tertulias, constituyen zonas que la novela va a ir delineando -y cuestionando- en relación con los diferentes lugares del escritor en el marco dictatorial. También se diseña una cierta topología de

\footnotetext{
${ }^{113}$ Como señala Serio Villalobos-Ruminott (2011: 203), la co-pertenencia entre la literatura y los horrores del poder conforman un oscuro pasillo sin salida, una relación dialécticamente estructurada que implica reconocer en los nuevos escenarios históricos e intelectuales que "la literatura no nos salva sino que nos remite a la misma lógica de la violencia constitutiva del mundo contemporáneo" (196).
} 
'colaboracionismo silente' con la dictadura a través de los elementos recurrentes que remiten a la simbología cristiana por medio de imágenes de la traición y la culpa: la figura de Pedro y de Judas, la cena, el árbol: “Chile entero se había convertido en el árbol de Judas, un árbol sin hojas, aparentemente muerto" (138).

Ese espejeo entre campo cultural y poder dictatorial ya se anticipa en la primera misión que los señores Oido y Odeim le encomiendan al sacerdote; los mismos que en los años de 'odio' y 'miedo' dictatoriales le piden que enseñe marxismo a la Junta militar. Pero esta primera misión implica a la institución eclesiástica.

El cura viaja a Europa, a pedido de la casa de Estudios del Arzobispado, para revelar datos sobre la conservación de iglesias; allí aprende que su mayor problema son las palomas (su excremento) y la solución, los halcones adiestrados por los curas para destruirlas. Esta anécdota se resignifica con los sueños del cura que, respondiendo al rasgo melancólico, perturban y alumbran otras lecturas de lo narrado. En el sueño, "veía una bandada de halcones, miles de halcones que volaban a gran altura por encima del océano Atlántico, en dirección a América” (95).

El horror que se instalará en Chile con el Golpe se desplaza a América Latina en el cruce de referencias que, ahora, aluden al horror pero en México, país que es otra constante en la narrativa de Bolaño. Los "Halcones" remiten directamente al grupo represivo que entre 1966 y 1971 integraron alrededor de mil agentes armados. Este grupo paramilitar, fundado por el coronel Manuel Díaz Escobar, participó de la masacre de Tlatelolco, el 2 de octubre de 1968; el mismo Bolaño afirmó haber sido joven testigo de esta matanza de estudiantes durante su residencia en México. Díaz Escobar fue trasladado como agregado militar a Chile, poco antes del golpe de Estado del 11 de septiembre de $1973 .^{114}$

La novela de Enrique Lafourcade, dos veces mencionada, Palomita blanca (1971), también es iluminadora: el intertexto funciona como articulador; recordemos los títulos de sus últimos capítulos: "Palomita negra, vidalita de piquito rojo crece palomita, vidalita y volvete halcón”. Los sesenta y setenta allendistas que la novela escenifica como marco de referencias ya no son válidos, especialmente en el contexto de unas clases de marxismo a Pinochet y otros altos miembros del gobierno militar. Pinochet

\footnotetext{
${ }^{114}$ La imagen paloma/halcón en relación a las dictaduras militares es una constante. En Argentina se utilizaron los términos para distinguir dos facciones dentro de las Fuerzas Armadas: los 'blandos' o 'palomas' y 'los duros' o 'halcones'. Aquí, en cambio, las palomas remiten a las víctimas de la dictadura.
} 
reconoce que leyó la novela y la comenta ("tampoco es para tanto" dice); las palomas transformadas en halcones sobrevuelan un Chile negro.

Violencia y complicidad en la ciudad letrada y en la Iglesia: los curas entrenaban halcones para matar a las palomas y el cura Ibacache enseña marxismo a Pinochet "para comprender a los enemigos de Chile, para saber cómo piensan, para imaginar hasta dónde están a punto de llegar” (118). Aquí se revela lo que Gonzalo Aguilar denomina "las oscuras relaciones entre el arte y la barbarie" (2001).

\section{El escritor melancólico}

La ficcionalización de la muerte de Pablo Neruda aparece como otro símbolo de la fractura, la caída, la pérdida. La muerte del gran poeta de la revolución se manifiesta como puesta en crisis de los valores heroicos del escritor comprometido. Desde un principio la figura de Neruda aparece ficcionalizada con rasgos de lo funeral, entre lo exagerado y lo irónico.

El cura conoce al poeta en el fundo de Farewell (otra vez los años cincuenta prefiguran, preparan lo que vendrá: ya en esta escena, la muerte de Neruda), en uno de esos paseos por los jardines distingue "una sombra, oblonga como un ataúd" (23) la cual murmuraba hondamente unas palabras "que no podían ir dirigidas a nadie sino a la luna. Era Neruda. Ahí estaba Neruda y unos metros atrás estaba yo y en el medio la noche, la luna, la estatua ecuestre y las maderas de Chile, la oscura dignidad de la patria” (23).

Unas páginas más adelante, muere el poeta. Las pompas fúnebres dignas de semejante personalidad se reducen a una escena tragicómica, casi irreverente, en el siguiente diálogo: “¿y dónde va Pablo? Ahí adelante en el ataúd” (100). Escena cuyos ecos resuenan en la segunda muerte, la del gran crítico literario Farewell (otra imagen de la pérdida, farewell significa 'adiós' en inglés) ${ }^{115}$ "Durante el entierro, mientras recorríamos las calles que eran como refrigeradores, pregunté dónde estaba Farewell. En el ataúd, me respondieron unos muchachos que iban adelante. Imbéciles, dije, pero los muchachos ya no estaban" (147).

La "orfandad” como el rasgo unificador que Cánovas señala para agrupar a los narradores del campo literario post Pinochet existe respecto de los "padres" canonizados

${ }^{115}$ Cf. además el poema de Neruda "Farewell". Citamos la primera estrofa: Desde el fondo de ti, y arrodillado, /un niño triste como yo, nos mira. Y última: Desde tu corazón me dice adiós un niño. Y yo le digo adiós. 
por los ideales de los años sesenta y setenta ya caducos; así como también respecto de la crítica literaria. Las muertes del poeta y del crítico expresan el estado del campo literario desde el que Bolaño escribe ${ }^{116}$ y manifiestan el fin de las figuras heroicas -Neruda, el gran poeta nacional, y Farewell "el estuario en donde se refugiaban (...) todas las embarcaciones literarias de la patria, desde los frágiles yates hasta los grandes cargueros..." (23)- como rasgo finisecular.

La tradición decimonónica sacraliza la poesía a partir de un proceso de secularización que quita a la religión la capacidad interpretativa y explicativa de la existencia, dándole a la poesía ese espacio vacante. En Nocturno... este proceso se invierte y cambia de signo: la poesía es del sacerdote pero ya no explica nada, no comunica, pues, en su intento de justificación, la escisión entre el olvido y la memoria delata un sentido imposible de fijar, de alcanzar.

El fin de siglo es re-leído como el fin de la dictadura y la pérdida de fe, los valores trastocados, los saberes -y los cuerpos- mutilados revelan el fin de las figuras comprometidas, militantes. Surgen, en este marco, dos relatos contra la heroicidad en la literatura, contra la sacralización del arte y a favor de una imagen melancólica que se refuerza y se narra en las dos historias intercaladas: la de Jünger con el pintor guatemalteco y la del zapatero vienés en la colina Heldenberg.

En el primer relato, se articula una nueva imagen de escritor a partir de la oposición entre el artista-héroe y el artista-melancólico, encarnado este último en la figura del pintor guatemalteco. En el marco opresivo de la Segunda Guerra Mundial, el artista latinoamericano pasa sus días encerrado en una pequeña habitación francesa con la única 'actividad' de contemplar la ciudad a través de la ventana. Claro exponente del morbus melancholicus burtoniano, ${ }^{117}$ el pintor es víctima de una aplastante inanición y hastío, condición reflejada en su única obra, un cuadro que muestra a México una hora antes del amanecer: barrios como negativos de fotografías y esqueletos difusos. Uno de los rasgos que la tradición melancólica destaca es el de la lucidez: desde Aristóteles la

\footnotetext{
${ }^{116}$ Más allá de posibles identificaciones biográficas (la crítica ha mencionado la ficcionalización del crítico chileno Ignacio Valente), creemos que Nocturno de Chile se integra al mencionado debate de la llamada "Nueva Narrativa chilena" al coincidir en que falta una crítica literaria para la literatura chilena (entre otros, C. Franz, A. Fuguet, R. Diaz Eterovic, J. Collyer, en Carlos Olivárez, editor, op.cit.)

${ }^{117}$ Es, dice Burton, un mal que se origina en la imaginación, de ahí trasciende a la razón y al corazón, y luego a otras partes del cuerpo como el estómago, el hígado y el bazo. El estado de melancolía se caracteriza por sentimientos como la tristeza y el miedo, que, convertidos en hábitos, pueden llegar a ocasionar la muerte. Una permanente angustia del alma; desvaríos en el discernimiento y la voluntad; pérdida de la razón; alteraciones en la facultad de expresión; desvaríos en las opiniones y las creencias, temor, tristeza y aflicción sin causa aparente, son algunos de los estados que caracterizan al ente melancólico. Robert Burton, Anatomía de la melancolía, [1621], Buenos Aires, Espasa Calpe, 1947.
} 
condición melancólica revela el genio de un ser lúcido cuyo saber se vuelve inútil ante la negatividad de su entorno, reflejo de su alma. La lucidez del guatemalteco solo le sirve para aceptar "la derrota de sí mismo" (62).

En segundo lugar, la historia del zapatero vienés, quien desea construir la Colina de los Héroes -cementerio y museo de los "héroes del pasado gratísimos a la memoria patriótica del zapatero" (57)-, termina con el fracaso de la empresa y con el esqueleto del zapatero como único testigo heroico de tiempos pasados (“(...) no vieron estatuas de héroes ni tumbas sino sólo desolación y abandono", 62). La muerte de estos héroes viene a completar las de Neruda y Farewell.

La diseminación de sentidos de "melanos" en todo el texto presenta una serie de tópicos que aluden al crepúsculo, el tedio, la inacción, lo funeral, la muerte. Desde el propio título, la novela nos muestra una imagen elegíaca de Chile como sombra, como muerte, reforzada por las alusiones al Nocturno de José Asunción Silva o a las angustiosas líneas de Giacomo Leopardi. Chile está signado por la inmovilidad, es un país de sombras chinescas, abatido por "el aburrimiento como un portaaviones circunnavegando el imaginario chileno" (132). Sin embargo, si el objeto de la pérdida es Chile, si el trauma es la experiencia del horror, entonces la melancolía resulta en el constante darse cuenta de que el duelo es inacabable (Avelar 2000). La imposibilidad de conclusión del duelo puede servir para mantener vigente la deuda con ese pasado violento, para no olvidar.

Ya la dimensión revolucionaria del arte como instrumento de resistencia y lucha deviene inutilidad. Si la melancolía desde una visión tradicional significa una quietud angustiosa, en los debates sobre la memoria en el Cono Sur adquiere una potencia crítica a partir de la posibilidad de una praxis política que efectúa el reclamo por las víctimas. El "acto melancólico" (Gunderman 2007) de ningún modo implica la inacción o la inmovilidad lacrimógena: "quítese la peluca" declama el epígrafe desenmascarador de Nocturno de Chile que cita a Chesterton. Este 'sacarse la máscara' a través de la melancolía funciona como quiebre de los preceptos de un arte comprometido pero también como vehículo para revisitar el pasado utópico a partir de un presente crepuscular.

Al preguntarse sobre la condición del escritor luego de los fracasos de los sesenta y el advenimiento de las dictaduras en los setenta, Bolaño anuncia y da nacimiento al escritor melancólico de los noventa. Podrá pensarse que Bolaño encarna la figura posdictatorial que Richard describe en los siguientes términos: "la 
imposibilidad de la afirmación vino (...) a impregnar de melancolía los años de duelo de la transición como síntoma de retraimiento solitario y depresivo, de falta de energía y paralización de la voluntad" (Richard 2004: 23). Sin embargo, Bolaño diseña una posición diferenciada en el campo chileno de la posdictadura a partir de la figura del escritor melancólico y ésta no se implica necesariamente como 'neutra' o 'inoperante'.

Por otro lado, Avelar advierte que el contexto posdictatorial de la derrota no puede ser sino melancólico; y el duelo, al no resolverse, demanda una memoria activa, en constante devenir presente, presencia. ${ }^{118} \mathrm{Y}$ la literatura, como toda práctica cultural, socava las fijaciones de sentido que derivan en 'memorias oficiales' cercanas a la amnesia, edificadas con el silencio tranquilizador de un pasado sellado. Entonces, como la escritura, la memoria aparece disruptiva, fragmentaria, no interesa el dato documentado, verificable sino las incidencias del horror en los sujetos y en qué medida es posible dar cuenta de ello.

Así, memoria y escritura signadas por la melancolía se revelan como acontecimientos de búsqueda y elaboración de sentidos a partir de la experiencia donde no interesan sólo los marcos empíricos (fechas, lugares) sino sus significaciones en el presente. Bolaño bautiza al escritor melancólico de los noventa como contrafigura del escritor de la revolución, de la resistencia heroica, quien asume revisitar el pasado traumático de la dictadura militar, desde un presente decepcionante.

Nocturno de Chile es la novela que lanza toda su potencia hacia las zonas conflictivas del Chile de la dictadura militar de Augusto Pinochet. ${ }^{119}$ La yuxtaposición de figuras ficcionales con personajes reales (como Neruda o Pinochet) y ficcionalizados (como el mismo cura Ibacache o María Canales) ${ }^{120}$ que la novela despliega es otra apuesta a la ficción para sondar los abismos de la historia reciente. El texto reclama la confesión de lo sucedido durante el terrorismo de Estado y exhibe la voluntad de

\footnotetext{
${ }^{118}$ Avelar, Idelber, Alegorías de la derrota, y en una entrevista: "Si no hay melancolía no hay trabajo, lo que hay es pura técnica, puro adaptarse a la vorágine que llamamos progreso, puro automatismo. Sólo hay praxis genuina cuando hay desolación ante la miseria, la catástrofe. La operación consiste en tomar duelo y melancolía como un par conceptual en el cual uno es la manifestación de la no resolución del otro, y transformar ese polo, la manifestación de lo irresuelto, en condición de posibilidad del término originario mismo." ("América latina, ficciones y derrotas", por Carlos Maldonado, 20 de agosto de 2000, en www.elmostrador.cl)

${ }^{119}$ Es una de las pocas, si no la única, novela "chilena" (aquí, y sólo aquí, vale el gentilicio) en las que aparece ficcionalizada la figura de ex dictador Augusto Pinochet de manera extremadamente crítica, entre la burla y el desprecio.

${ }^{120} \mathrm{La}$ anécdota real que Bolaño toma de la crónica de Pedro Lemebel ("Las orquídeas negras de Mariana Callejas (o "el Centro Cultural de la Dina")" -en De perlas y cicatrices- que Bolaño recuerda en Entre paréntesis, 77) cuenta cómo en la misma casa de los talleres literarios de Maríana Callejas se torturaban detenidos en el sótano; ella era esposa de Michael Townley, agente de la DINA.
} 
testimoniar como acto de memoria. Sin embargo, lo hace en el cruce entre el testimonio y la ficción dándole voz a una figura oscura que complejiza todo intento por simplificar lo sucedido. 


\section{2. Testimonio y fantástico. Relecturas de la tradición latinoamericana}

Otra articulación entre el testimonio y la ficción es la que abordamos a partir de la intervención del fantástico en el relato tal como leeremos en novelas como Amuleto y Monsieur Pain. Para ello es necesario explorar el uso que Bolaño hace del fantástico en el contexto de la tradición literaria latinoamericana desde los realismos mágico y maravilloso y del fantástico rioplatense para articular su "realismo visceral". En ningún modo se establece una continuación de tradiciones y estéticas anteriores sino por el contrario Bolaño opera una transformación de esa biblioteca latinoamericana de manera tal que es necesario revisitar sus zonas más importantes para reubicar sus alcances en el Hipertexto-Bolaño.

\section{Ni mágico ni maravilloso: el realismo visceral y las huellas del fantástico rioplatense}

Explorar las posibilidades que Roberto Bolaño abre al socavar y recuperar, a su vez, ciertos nudos fundamentales de la tradición literaria latinoamericana de los últimos años (particularmente de los sesenta) no sólo implica instalar al escritor en una tradición particular sino también permite expandir los alcances de su poética hacia otras fronteras geográficas y culturales. Por ello es necesario dilucidar cómo esta empresa al mismo tiempo que ancla su escritura en América Latina reconvierte toda noción de patria, de origen y la desplaza hacia la intemperie, el abismo en que se ha transformado la realidad -una realidad signada por el horror y la violencia que desconoce fronteras, límites, gobiernos. En este capítulo intentaremos iluminar la propuesta estética del escritor chileno dirigida a discutir y desplazar las tendencias hegemónicas (y enfrentadas) en torno a la década de los sesenta y setenta latinoamericanos a partir de la categoría de "realismo visceral" propuesta por el mismo autor para explorar sus alcances, reescrituras y transformaciones.

El cambio de nombre, del "infrarrealismo" en su juventud mexicana al "real visceralismo" o "realismo visceral" en Los detectives salvajes aunque poco ilumine el registro de su estética, o la índole de su escritura, resulta significativo porque retoma, invierte y rescribe - casi con burla aun cuando el mismo Bolaño poco nos diga - las 
etiquetas de "lo real maravilloso" y del "realismo mágico", dominantes en la narrativa del boom latinoamericano de los cincuenta sesenta y cristalizadas luego en epigonales estereotipos. Aquella imagen idílica, mágica, maravillosa de América Latina -articulada en parte alrededor de la revolución cubana- que algunos perciben en el macondismo en tanto clisé-, se quiebra en esta etiqueta del realismo visceral para narrar los restos que dejaron las dictaduras de los setenta, para hurgar en las vísceras de la historia. Lo visceral alude a un doble sentido, refiere a los órganos internos del cuerpo, a las entrañas de la barbarie, y describe una lesión emocional muy intensa, una herida en la subjetividad. Además, el realismo visceral instaura una oscilación entre un discurso fuertemente referencial y un relato que debilita las certidumbres de lo "real" y suma las posibilidades de la ficción, como vimos.

El realismo visceral funciona, entonces, como matriz para relatar la experiencia del horror y sus significaciones en la historia reciente. En esta línea, su obra reescribe desde otro lugar y constituiría una nueva entrada a las novelas de dictadores de Augusto Roa Bastos, Gabriel García Marquez, Alejo Carpentier, Carlos Fuentes, entre otros, articulando dictaduras latinoamericanas recientes con lo que denominamos -con él"realismo visceral".

Se trata de un realismo o vuelta a "lo real" definido de un modo por completo nuevo, y que en los noventa contempla el paisaje que dejaron las dictaduras y los fantasmas que convocaron, lo que Analía Capdevila denomina "lo inconcebible" ("lo imposible de pensar, es el horror mismo que no encuentra explicación", 2009: 145). También exploraremos cómo el efecto de lo real es contaminado por un impulso de lo fantástico que desrealiza objetos, personajes, sucesos, y revela lo siniestro, revela sus vísceras. En los modos que Bolaño esgrime para explorar "la opacidad de lo real"121 se apunta a descubrir los dobleces de una realidad cuya superficie sólo delata otras capas (ocultas, reprimidas, traumáticas) que es necesario sondear. Así, postulamos que frente a la tradición caribeña de lo real maravilloso, Roberto Bolaño elige retomar el fantástico rioplatense de espectros y pesadillas. La lectura que Bolaño realiza de este trasfondo latinoamericano le permite reescribir sus líneas más interesantes y transfigurarlas con

\footnotetext{
${ }^{121}$ En otro contexto, Joan Oleza postula las bases de un "realismo posmoderno" evitando caer en la fórmula que condena al realismo como lo tradicional, ingenuo o idiota. Su propuesta transita "por otra línea de debate, no la que contrapone tradición a experimentación, sino la que reúne o separa arte y vida cotidiana, la que dirime las relaciones entre estética y ética, la que discute la autosuficiencia del universo estético respecto de los otros universos de cultura" $(1995,39)$. Para Oleza hablar de realismo en los últimos años es indagar en las formas narrativas que explícitamente se hacen cargo de explorar lo real y entrelazar arte y vida, "de explorar y descifrar la opacidad de lo real" $(1995,39)$.
} 
una mezcla brillante de sentido de humor y melancolía enunciando el paisaje desolado, infernal, por el que trashuman las figuras fantasmales de Césarea Tinajero, Auxilio Lacouture, Pierre Pain o las mujeres asesinadas en la frontera mexicana de Santa Teresa.

Dos movimientos - una renovada apelación a lo real y la articulación de un realismo adjetivado- se encuentran, como veremos, en la vocación de Roberto Bolaño por reactivar el impulso testimonial hacia lo real (aunque no obedeciendo el protocolo de género) pero atravesado por lo fantasmático y rearticulado en el "realismo visceral". La propuesta del escritor chileno se dirige a discutir y desplazar tanto el testimonio como los realismos mágicos y maravillosos que constituyeron las dos tendencias hegemónicas (y enfrentadas) en torno a la década de los sesenta y setenta latinoamericanos para recuperar elementos del fantástico que en América Latina la crítica ha circunscripto al área del Río de La Plata.

\section{Realismos contaminados}

En los últimos años la categoría "realismo" ha resurgido como tema para la crítica literaria y ha provocado no sólo discusiones en torno a los usos del realismo por parte de los escritores sino a los modos de leer un cierto realismo por parte de los críticos. Es decir, más allá de pensar los trabajos que un escritor realiza con, desde o contra una estética realista, el debate ha provocado ciertas posturas críticas que responden a lecturas ancladas en una tradición que por lo menos habría que revisitar. Tal estado ha sido detectado lúcidamente por Sandra Contreras (2006) en la literatura argentina cuando -para definir las experimentaciones que autores como César Aira o Rodolfo Fogwill, entre otros, realizan con el realismo- se corre de los lugares comunes que han cimentado una concepción del realismo clásico como mimético, descriptivo, austero y banal (Dalmaroni 2002).

Ya nadie defiende abiertamente las posibilidades de una mímesis realista que ignore los reparos a la dupla lenguaje/realidad -signada por la "imposibilidad", o la “desconfianza"- y rápidamente se constata que la fe en los alcances del lenguaje para representar fielmente la realidad quedó encajonada allá por el siglo XIX o primeras décadas del XX. Sin embargo, los modos en que se lee el denominado "retorno a lo real" en la literatura de los últimos años responden subrepticiamente a cierto canon de lectura algo decimonónico. Es decir, para acercarse a los usos del realismo en el siglo 
XX, y XXI, se apela a procedimientos y juicios estéticos que apuntan a un verosímil realista del siglo XIX (y hasta a un cierto decoro algo anterior). Como señala Contreras (2006) se vuelven interesantes así los valores de lectura (qué y cómo leer) y es preciso dar cuenta de una "transformación de los modos de representación" así como de "la noción misma de real" (Contreras 2006)

José Luis De Diego ha sistematizado por lo menos dos "soluciones" para volver a pensar la categoría "realismo". Una es la adjetivación, mediante la cual se define una particularidad, ciertos rasgos que manifestarían un uso específico del realismo por parte de un autor (los "realismos adjetivados" que ya no son novedosos y cuya lista es larguísima: socialista, crítico, delirante, inseguro, cosmopolita, sucio, virtual, visionario...) Otra solución es apelar directamente a "lo real", a un estado previo que se resiste -advierte De Diego- desde siempre a los mecanismos de representación mimética (De Diego 2001). No se trata sólo de leer estilos, o formas para representar fielmente la realidad, sino de ver también cómo y por qué se incorpora lo real. Así, la categoría realismo se individualiza para describir la manera en que la realidad irrumpe en la escritura de uno u otro escritor. Se trataría entonces de una vuelta a lo real, donde "realidad" ya no puede ser definida simplemente como lo observable, capaz de reflejarse en un espejo, donde una nueva y particular visión de mundo se concreta en nuevas formas.

En América Latina la tradición del realismo en el siglo XX ha estado signada por la fuerte presencia de las denominadas narrativas de la tierra, nativismos y regionalismos, que configuraron una propuesta estética y crítica a partir de los trabajos de Ángel Rama y Carlos Alonso, entre otros. Este regionalismo fue recuperado por la entonces denominada nueva narrativa latinoamericana de los años cuarenta que será luego la base del boom de los sesenta/setenta. Esta continuidad o transculturación, al decir de Rama, dará lugar entonces a las narrativas que cruzan técnicas vanguardistas vinculadas a las grandes urbes con una escena localizada ya sea en el interior, en zonas rurales o en espacios periféricos.

La cuestión del realismo participa de los debates del campo intelectual de los sesenta/setenta en continuidad con líneas anteriores. Como señala Claudia Gilman en su exhaustivo trabajo sobre la época (que retoma el temprano análisis de Ángel Rama sobre el boom) escritores y críticos se propusieron liberar al realismo de su carácter prescriptivo para conjugar el impulso hacia lo nuevo que implicó la correlación vanguardia política-vanguardia artística (Gilman 2002: 318-319). A principios de los 
sesenta hablar de "nuevo realismo" era colocar a la narrativa latinoamericana en un horizonte estético de ruptura que renovara tradiciones y técnicas narrativas. La adjetivación que De Diego notara en las discusiones del campo literario argentino de los ochenta, en el mapa latinoamericano de los sesenta/setenta (e incluso varios años antes) ya estaba fundando una tradición que luego se volvería -para algunos- una etiqueta vacua. El realismo mágico pasó a ser una marca registrada a pesar de que, como indica Gilman, "los nuevos proyectos novelísticos no se formularon en términos conceptuales muy precisos" (324). Sin embargo, esa adjetivación, y la nominalización de "lo real maravilloso" que Alejo Carpentier propone en el célebre prólogo a El reino de este mundo fue objeto de estudio y discusión. En explícita oposición a un realismo empírico, la crítica se enfrentó a la necesidad de diferenciarlo de la "literatura fantástica" destacando su impronta bien americana, conjugando lo extraño (Anderson Imbert 1976), propio de la "magia" del continente (Mignolo 1980) y de la historia americana, "una crónica de lo real maravilloso" (Carpentier 1966).

Así, en principio, el realismo visceral de Bolaño se distancia del realismo mágico o lo real maravilloso en tanto índices de una búsqueda de identidad latinoamericana basada en nociones esencialistas, atravesada por la idea de mundo nuevo forjada desde Europa. También prefiere recuperar la tradición del fantástico rioplatense justamente reforzando la imposibilidad de construir definiciones que se puedan articular en un sintagma esencialista pero que aun así permitan explorar la historia reciente desde una perspectiva que supere lo utópico, incorpore los fantasmas de la barbarie reciente y dé cuenta de una complejidad que no puede reducirse a formas estancas.

\section{Algunas notas sobre realismo mágico y lo real maravilloso}

Los primeros aportes de la crítica respecto del realismo mágico sólo dan cuenta de la confusión inicial que significó delimitar una categoría nueva -que además surgía en la pintura- ${ }^{122}$ para nuevas propuestas estéticas.

Desde el trabajo pionero de Ángel Flores en 1955 la crítica ha discutido prolíficamente las posibilidades del realismo, el fantástico y las adjetivaciones "mágico" y "maravilloso" en la literatura latinoamericana. Flores incorpora el realismo mágico a 
la literatura fantástica y reconoce la novedad de la literatura de América en esa amalgama de realismo y fantasía que resultaría a la manera de los textos de Franz Kafka (mientras que Edgar Allan Poe y el decadentismo francés habían influenciado a las generaciones anteriores, la de los cuentistas y poetas modernistas). Para Flores ya existe una tradición literaria, que se remonta al período colonial, en la cual se alterna el realismo y lo mágico, sin embargo, es a partir de 1935, con la publicación de Historia universal de la infamia de Jorge Luis Borges, cuando empieza a vislumbrarse una nueva etapa que difiere de las precedentes. ${ }^{123}$ Contra todo sentimentalismo y populismo anteriores $^{124}$ Flores más que caracterizar una nueva tendencia de la literatura latinoamericana intenta colocar la obra de sus contemporáneos en un espacio intelectual más amplio con centro en las letras europeas (de ahí la extensa lista de narradores que serían mágico-realistas a la luz de sus textos 'a la manera de' el mencionado Kafka, Gide, Wells, Schwob, Camus, entre otros -incluso evoca las pinturas de De Chirico). Esta voluntad de universalizar la novedosa narrativa hispanoamericana también se solapa al definirla dentro de los parámetros de la literatura fantástica ya canonizada.

Más de una década después, Luis Leal (1967), reconociendo el pionerismo de Flores respecto de su incursión en definir los rasgos del "movimiento" (231), discute la confusión entre realismo mágico y literatura fantástica. Cita a Franz Roh, quien es reconocido por acuñar la nueva categoría en el arte europeo, para diferenciarlos: si lo sobrenatural irrumpe en la literatura fantástica, en el realismo mágico estaría tras las cosas mismas. Sin decir cómo, habría que "desentrañar", “captar", "adivinar" los "misterios" del mundo externo sin necesidad de justificarlos (234). El nuevo concepto arraiga en Latinoamérica con las intervenciones de Arturo Uslar Pietri y luego, para Leal, con las de Alejo Carpentier. Así, se acerca el realismo mágico con lo real maravilloso y se lo diferencia del fantástico. Dejando a Borges de lado, Leal arma su propia lista de realistas mágicos en su mayoría caribeños o 'del norte' (como Alejo Carpentier, Miguel Ángel Asturias, Juan Rulfo) e incluye a Julio Cortázar dentro de esta “actitud ante la realidad" (232).

En esta misma línea, Ángel Valbuena Briones (1969) comienza su artículo enfrentando el realismo mágico con la literatura fantástica para hacerlas confluir en la

123 Por su "fría y cerebral manera de narrar, a veces erudita" (189) y "la transformación de lo cotidiano en lo sorprendente e irreal" (traducciones nuestras, 190).

124 All the magical realists have this in common, as well as their repudiation of that mawkish sentimentalism which pervades so many of the Latin American classics (...) do not cater to a popular taste, rather they address themselves to the sophisticated, those not merely initiated in aesthetic mysteries but versed in subtleties" (191) 
necesidad de una dimensión ilusoria, una fantasía o un mito para dar sentido a la realidad americana (233). Por un lado, los elementos "irracionales y primitivos" (236) del continente americano, su mitología, circunscriben localmente la categoría pero por otro lado, Valbuena Briones hace hincapié en que es una "corriente universal" (236). Concuerda con Ángel Flores en definirlo como una modalidad del fantástico y ubica a Borges y Carpentier, Cortázar y Asturias dentro del realismo mágico. De esta manera, le quita originalidad y novedad tanto al concepto como a su definición: repite los modos sistematizados por la literatura fantástica que también ya había enumerado Flores ("acepta lo maravilloso en un tipo de relato realista" (236) en el caso de Borges, por ejemplo). Podemos destacar el intento de Valbuena Briones por definir el realismo mágico como una modalidad superadora del realismo clásico, aunque sus comentarios iluminen más una aproximación al fantástico rioplatense. En este sentido, resulta interesante su concepción del fantástico como un modo de explorar profundamente la realidad y no como una mera forma de evasión. Cuando analiza los cuentos de Julio Cortázar rescata el afán por "ver las cosas desde todos los puntos de vista posibles" (240), lo que resultaría en una visión más completa comparada con el retrato de un naturalista, por caso (241). Retomaremos la cuestión del fantástico más adelante.

Estas primeras apreciaciones intentan definir una renovación de las letras latinoamericanas por un lado, frente al monótono discurso del realismo socialista vertebrado en preceptos decimonónicos y por el otro, frente a la literatura fantástica permeada por el surrealismo. La “crisis del realismo" (Emir Rodríguez Monegal [1952] 1976, Ramón Xirau 1972) que incentiva nuevas formas narrativas también fomenta intervenciones críticas que deben hacerse cargo de circunscribir viejas categorías (realismo, fantástico) a nuevas expresiones, nueva actitud o sensibilidad (como definía Luis Leal). ${ }^{125}$ La clasificación de Rodríguez Monegal indica la embrionaria tarea crítica para delimitar estéticamente a los narradores de esta América: desde el caduco realismo regionalista al realismo cosmopolita, de la literatura fantástica hasta la "superación del realismo" (42) que ya se vislumbraba a mediados de la década del 40.

\footnotetext{
125 Tal como afirma Antonio Planells (1988) respecto de las vicisitudes del concepto en la crítica hispanoamericana desde los años 50 a los 80, que refleja la carencia de una terminología adecuada, la falta de una tradición que encauce la crítica literaria a indagar en un "fenómeno de frontera" (15) donde alternan, para Planells, "la luz y la sombra, la vida y la muerte, el sueño y la vigilia, la civilización y la barbarie, lo sublime y lo ridículo, la cordura y la enajenación, y todos sus estados intermedios (la penumbra, la ensoñación, etc)" (16). También para este autor pertenece a una de las varias formas de la literatura fantástica.
} 
Para Xirau esta nueva etapa de fusión entre realidad y fantasía que Flores había señalado se alza contra el costumbrismo, documental y localista para crear nuevas realidades más allá de lo cotidiano (189). Esta búsqueda ${ }^{126}$ refiere la realidad americana desde lo que Xirau denomina una "universalidad enraizada", que puede localizarse puntualmente en Macondo, por ejemplo, pero que a su vez es universal (203). A partir de los setenta, el realismo mágico será circunscrito por la crítica al ámbito latinoamericano, y si bien numerosos artículos e intervenciones se ocupan de la categoría las preocupaciones continúan en la línea de décadas anteriores. Índice de tal estado de la cuestión son las ponencias del Congreso Internacional de Literatura Iberoamericana de 1973, en Michigan, donde las coordenadas apuntan a los cruces y distancias del realismo mágico-maravilloso, el fantástico y el surrealismo.

Si en un primer momento confuso para la crítica, se leyó el realismo mágico como una modalidad que hace eco - o no- de tradiciones europeas para luego ir anclándose cada vez más en territorio latinoamericano, será luego un modo de aprehender una realidad diferente, una realidad otra. El realismo mágico será, no solo una corriente estética sino sobre todo, una unidad cultural. Aquí se lo fusiona con o se lo intenta deslindar de lo real maravilloso que Alejo Carpentier primero define en el prólogo a El reino de este mundo. Para el escritor cubano es una categoría identitaria que nombra la realidad americana y que se fragua en el cruce entre lo real y lo maravilloso en tanto la realidad misma (esa realidad tan documentada, de nombres, fechas y cronologías) es maravillosa (por su naturaleza exultante y huracanada, la cultura de herencia africana como el vudú, las arquitecturas grandiosas, las constantes revoluciones y revueltas, entre otras). Desde ese lugar critica a lo maravilloso surrealista como una racionalidad europea propia del "viejo mundo" donde el hombre ha perdido la fe y el contacto vital con la naturaleza. Mientras que lo real maravilloso carpenteriano percibe a América Latina como un "nuevo mundo" en el cual el hombre conserva un vínculo estrecho con la naturaleza y una religiosidad viva.

Cuando analiza El reino de este mundo y su "Prólogo", Emir Rodríguez Monegal (1971) destaca la escritura como "alquimia" pues es el propio trabajo del autor que transforma la historia de Haití en pura maravilla (639). Sin embargo, afirma que lo real maravilloso si bien es una categoría de la obra de arte, aparece como un "elemento de toda la realidad americana" (635). A esto apunta el mismo Carpentier cuando opone

\footnotetext{
${ }^{126}$ Dice "búsqueda literaria que no se conforma con un realismo referido a los hechos" (189)
} 
la estética surrealista, o el realismo socialista a las posibilidades que la realidad americana -su naturaleza, su historia, su experiencia- le ofrece al escritor americano. ${ }^{127}$ Esta esencia se define por oposición: no es, no está en Europa. Pero si vamos a la novela, la visión europeizada, racionalista nunca se abandona, porque Europa sí está en América desde Colón. La crítica posterior ha destacado cómo El reino de este mundo está vertebrada en este cruce de la visión de Haití y la imaginería europea (Rodríguez Monegal 646), ${ }^{128}$ y es esta contaminación o mestizaje estético lo que para Roberto González Echevarría (1993) denuncia la máscara del prólogo:

Ante la patente contradicción implícita en el primero (lo real maravilloso), la de no poder, entablar entre la "cultura" y el escritor un diálogo que ni implique la reificación, la distancia, la ruptura; al no poder convertirse en "autóctono y salvaje" en el momento de la escritura, la única posibilidad es el desdoblamiento del yo, la máscara del prólogo (182-183)

Hay una visión de lo primitivo como elemento propio del continente que permite el rasgo maravilloso frente al caduco racionalismo europeo, del cual el narrador no se aparta completamente. Pero también la capacidad revolucionaria del vudú, del caso haitiano, supera un primitivismo que clausure lo autóctono como inferior, imperfecto. ${ }^{129}$ Es aquí donde el concepto de lo real maravilloso funciona como un discurso que refiere lo americano desde una doble matriz, que recupera lo arcaico, lo primitivo, lo mítico del continente y a su vez lo enfrenta con el elemento europeo que también fraguó cosmovisiones, despuntando aquella que anuncia la decadencia de occidente.

Carpentier recupera las ideas de Oswald Spengler para resaltar con signo positivo el caudal aún no agotado de América, a diferencia de Europa de cuya cultura (occidental) Spengler había anunciado su ocaso; es decir, si se acercaba el fin de un ciclo, lo real maravilloso americano indicaba que del lado de acá todavía se podía lucir la etiqueta de mundo nuevo. Este primitivismo del buen salvaje se convierte para Carpentier en el salvaje revolucionario, conjugando así dos visiones de mundo compartidas, amalgamadas. La religión vudú y la declaración de los derechos del

\footnotetext{
127 Para la contextualización del "Prólogo" en los debates con el surrealismo remitimos al artículo mencionado de Rodríguez Monegal. También: Víctor Bravo

${ }^{128}$ El pasaje más citado para ilustrar esto es el de la ejecución del manco Mackandal, donde la perspectiva mágica de la multitud negra contrasta con la explicación racional del narrador.

${ }^{129}$ Como recuerda Erik Camayd-Freixas en su estudio sobre realismo mágico y primitivismo: el "problema etnocentrista es adjudicarle a la cultura primitiva el estigma de la inferioridad" (14).
} 
hombre pertenecen a una misma cultura. La vuelta de tuerca de Carpentier entonces recupera una tradición europea del discurso americanista pero la transforma para que esta vez sea un discurso americano. Al rescatar la validez de lo americano no occidental, sin abandonar lo europeo (que también es americano) lo real maravilloso advierte que la religión en Haití no es el opio de los pueblos sino un arma política, e invencible. Contra toda idealización de lo europeo se recupera lo americano, como muestra el fin de Christophe y su corte napoleónica de negros, quien "había querido ignorar el vodú, formando a fustazos, una casta de señores católicos" (Carpentier 106) ${ }^{130}$ Es así como lo real maravilloso se vuelve una teoría sobre América, no sólo sobre las relaciones entre literatura y realidad.

Si bien se ha intentado diferenciar los conceptos de realismo mágico de la teoría de lo real maravilloso, ambos se vuelven a fusionar al leerlos como una nueva etapa dentro de los discursos americanistas que comienzan con las crónicas de conquistadores y colonizadores. De hecho, el exhaustivo trabajo de Irlemar Chiampi (1983) sobre esta cuestión define un realismo maravilloso agrupando ambos conceptos y lo más interesante es considerarlo "una ideología de América" (14) tal como resalta Emir Rodríguez Monegal en el prólogo. Al colocar el discurso del realismo maravilloso dentro de los modos en los que se ha intentado definir la cultura americana, Chiampi destaca lo real maravilloso como el oxímoron que mejor expresa la identidad del continente en su esfuerzo por descolonizar la cultura. Señala la crítica brasileña: "La indagación sobre el carácter nacional -la mexicanidad, la argentinidad, la chilenidad, etc. - está en la raíz de la etapa de conciencia crítica de la realidad americana, que evolucionó hacia un concepto positivo del mestizaje como signo de la cultura americana (...) el mestizaje es el verdadero criterio para postular la diferencia latinoamericana, en relación a los modelos europeo y norteamericano así como también es el criterio para configurar un bloque cultural, diversificado por variedades regionales, aunque homogeneizado por la receptividad ante las influencias" (154).

\footnotetext{
${ }^{130}$ Aunque curiosamente nunca lo mencione, Susan Buck-Morss desarrolla esta idea en su revisión de la historia de la esclavitud y los ideales iluministas a partir de la "constelación Hegel y Hait'" que propone (11). Su planteo parte de la hipótesis según la cual Hegel basó su teoría de la relación amo- esclavo en los acontecimientos de Haití, Buck-Morss instala una mirada otra sobre el potencial americano y da cuenta de las ausencias y omisiones recurrentes de la historia eurocéntrica moderna en la "mirada americana". En esta línea, Carpentier al hacer foco en las creencias afroamericanas y su papel en los acontecimientos independentistas, trata de recuperar una porción de la historia revisando los modos en que los países centrales establecen su vínculo con las culturas de la periferia y cómo las afectan. Buck-Morss sólo menciona a Carpentier en una nota al pie para señalar algunas referencias a la masonería en El siglo de las luces.
} 
Pero Emile Volek (1970) ya había separado las aguas entre realismo mágico y lo real maravilloso delimitando al primero como los modos en que la estética narrativa trabaja el referente americano definido por el segundo. Así el realismo mágico sería un método estético específico (171) mientras que lo real maravilloso refiere la realidad extraliteraria que la obra elabora (172). También a esta altura resulta pertinente resaltar que para Volek ambos conceptos se circunscriben geográficamente al espacio caribeño. Si bien representan una visión del continente se enmarcan particularmente en la parte tropical de América.

Y además recordemos que para Carpentier, lo real maravilloso es algo que el artista toma y transforma pero que está ahí, que "fluy(e) libremente de una realidad estrictamente seguida en todos sus detalles" (Carpentier 12). Mientras que el fantástico ofrece un sistema de superficie y profundidad, donde tras lo real se esconde algo latente que hiere.

La falta de conflicto que supone el ingreso de lo irreal, lo sobrenatural o lo imposible en el realismo mágico contrasta con la noción de fractura que supone el fantástico. Como tantos otros, Irlemar Chiampi contrasta ambas estéticas, mientras que el fantástico desestabiliza, cuestiona o conmueve, en el realismo maravilloso -tal la síntesis que la crítica brasileña propone- ${ }^{131}$ no hay contradicción, hay contigüidad entre lo real y lo irreal (1983: 69-70). La isotopía que despunta en los modos del fantástico quiebre, ruptura- permiten a Bolaño articular su realismo visceral con las zonas oscuras de la historia reciente que rebasan todo discurso racional.

En síntesis, el interés por la imago de América Latina que dominó los sesenta no está en Roberto Bolaño pues prescinde abiertamente de capturar un vector de búsqueda de la identidad latinoamericana a través de alguna forma, como lo fue el barroco o lo real maravilloso. En cambio, Bolaño sí persigue un interés por explorar y procesar las dictaduras, los traumas de la historia reciente.

\footnotetext{
${ }^{131}$ Chiampi argumenta que el adjetivo "maravilloso" -ya sistematizado por la crítica literaria- es más coherente que "mágico", perteneciente a otra serie
} 


\section{Del infrarrealismo al realismo visceral}

Como vimos en el apartado sobre Los detectives salvajes, las primeras reflexiones de Bolaño sobre sus preocupaciones estéticas provienen del "Movimiento Infrarrealista" de jóvenes poetas que el autor lideró junto a Mario Santiago y Bruno Montané, entre otros, durante su residencia en México a mediados de los 70. Si bien los 'preceptos' del movimiento (resumidos en "Déjenlo todo, nuevamente. Primer Manifiesto del Movimiento Infrarrealista", 1976) ${ }^{132}$ definen la poesía del joven Bolaño, constituyen los núcleos a partir de los cuales se pueden trazar algunas líneas iniciales de una poética narrativa bolañana. ${ }^{133}$

Miguel Donoso Pareja (en el prólogo a una antología de poetas infrarrealistas publicada por Bolaño en 1979) define el infrarrealismo recuperando la idea de movimiento y aceleración propia de las vanguardias con profundo lirismo que da cuenta de la realidad circundante, y que se expresa a través de los temas del amor o del crimen (1979, 13-36). De sus características podemos destacar, en especial, aquellas que insisten en una "visión desesperanzada" de la realidad y en un sentido "confuso, sin metas", ya que perdurarán en su posterior narrativa (recordemos que Bolaño cuando funda el infrarrealismo ya había experimentado la derrota de Salvador Allende en 1973)

\section{El Fantástico}

Como señala José Luis De Diego, el canon mimético es el más adecuado para representar la experiencia (p243), pero el relato del trauma exige aproximarse por otras vías. Así, este realismo visceral, por un lado, da cuenta del impulso de lo fantástico y a su vez no instaura las certezas que supone el realismo al introducir efectos de incertidumbre pues el efecto de lo real es contaminado por las astillas del fantástico. El fantástico en el Río de la Plata abre diversas posibilidades estéticas, como veremos, y

\footnotetext{
${ }^{132}$ Manifiesto escrito por Bolaño y publicado en Correspondencia Infra, Revista Menstrual del Movimiento Infrarrealista, $\mathrm{N}^{\circ} 1$ (México D.F, Octubre/Noviembre 1977, 5000 ejemplares). Ver: Espinosa (2005-9 y Madariaga Caro (2010).

${ }^{133}$ Matías Ayala bien nota que: "Hoy en día es posible sostener que el infrarrealismo le debe su existencia al real visceralismo (o realismo visceral) de Los detectives salvajes más que a la obra poética de Mario Santiago, Roberto Bolaño y sus demás integrantes. El infrarrealismo es más literario que real, o, más bien, se volvió real en la medida en que fue ficcionalizado en Los detectives salvajes" (2008: 92)
} 
Bolaño recupera todas ellas y se coloca como otra línea viable que se vincula con lo ominoso.

La crítica se ha detenido en el análisis de los diferentes géneros que Bolaño pone a funcionar en su narrativa (como el policial, la ciencia ficción o las biografías) desde las nociones de margen, desplazamiento o subversión. ${ }^{134}$ Las apariciones fantasmales constituyen el rasgo fundamental que Bolaño explota para iniciar los mecanismos del fantástico. Si bien el tono desacralizador de Bolaño apunta a la parodia, tal como aparece en algunos relatos, creemos que no es posible reducir el funcionamiento del fantástico a un método de escritura lúdico e irreverente.

Sin clausurar los textos de acuerdo con referentes históricos es innegable que una de las principales obsesiones de Roberto Bolaño reside en las muertes, rupturas y herencias de la historia reciente latinoamericana, en iluminar diferentes formas para pensar los giros de la barbarie y sus reflejos en la cultura, en un marcado interés por explorar las batallas de la literatura y de la historia en un arco que une las dictaduras latinoamericanas con otros nudos traumáticos de Europa. Como señala Archimboldi, en 2666: "La historia, que es una puta sencilla, no tiene momentos determinantes sino que es una proliferación de instantes, de brevedades que compiten entre sí en monstruosidad" (Bolaño 2004: 993). Como ya mencionamos, las relaciones entre la historia latinoamericana y la literatura se tamizaron a la luz de lo mágico o lo maravilloso desde un espacio tropical de profusión y exuberancia. Otro camino transitó la crítica para explorar el derrotero de la narrativa en el sur del continente, y el género fantástico se arrogó un espacio privilegiado en la conformación de una tradición rioplatense que indaga en sus posibilidades estéticas. Se articulan entonces dos líneas diferenciadas, por un lado, los realismos mágico y maravilloso radicados emblemáticamente en la obra de Gabriel García Márquez y el cubano Alejo Carpentier y, por otro lado, el fantástico en el Río de la Plata. Ambas tendencias son consideradas como modos de entender lo real, por fuera de los mandatos del realismo socialista. ${ }^{135}$ Annick Louis señala que, en el marco del boom latinoamericano, el género fantástico ocuparía un lugar algo incómodo "al insertarse en un universo cultural occidental universalizante, o en todo caso, percibido en menor medida como típicamente

134 Tal es el caso del fantástico, por ejemplo, para Felipe Ríos Baeza que ingresaría "por razones creativas que le permitirán ulteriormente la utilización del recurso del desplazamiento paródico" (2011: 166).

${ }^{135}$ Pampa Arán también las separa a partir de un rasgo que será fundamental también en las lecturas de Bolaño: "en el fantástico ronda siempre lo ominoso y por eso no acordamos con la incorporación del realismo mágico" (1999: 39) 
latinoamericano" (2012: 126). Además, más allá del "realismo mágico", el fantástico ya se había constituido como un objeto reconocible y es precisamente desde el sur que se lo visibiliza, a través -por ejemplo- de la Antología de la literatura fantástica compilada por Jorge Luis Borges, Adolfo Bioy Casares y Silvina Ocampo en 1940, o de los trabajos críticos de Ana María Barrenechea, como La literatura fantástica en Argentina de 1957 (Louis 126-9).

En los setenta, la discusión en parte se alimentó de los trabajos de, entre otros, Tzvetan Todorov, Louis Vax y Ana María Barrenechea sobre el fantástico (se prescinde por entonces de las innovaciones teóricas de Rosemary Jackson). Las lúcidas consideraciones de Ángel Rama son las que iluminan una línea del fantástico que luego se definirá bajo los límites geográficos del Río de La Plata. El crítico uruguayo incorpora tempranamente lo fantástico a América Latina desde el Cono Sur bajo los rasgos de "una especie de rasgadura en la realidad aparencial en que nos movemos" (Rama 1970: 42), en la cual se fractura la experiencia. Los dos modelos que hacen sistema aquí -liderados por Franz Kafka y Edgar Allan Poe, junto con el gótico inglésconjugan lo monstruoso -que sólo puede derivar de la razón (Kafka)- y “el cientificismo de lo fantástico" que intenta interpretar lo que aun no entendemos (Poe).

Ángel Rama integra el fantástico en América Latina como una manera de oponerse a lo real en su versión totalizante ya desde el modernismo (Rama 46). Con resabios de Rubén Darío y Leopoldo Lugones, el primer momento fuerte del fantástico comenzaría en el sur, con Horacio Quiroga y continúa con Jorge Luis Borges y Julio Cortázar, fundando una línea de "fantasmas, delirios y alucinaciones" como indica el título del artículo de Rama. Y es Noé Jitrik quien resume los postulados de Rama en una intervención que rebalsa la dicotomía realismo/fantástico, racionalización/imaginación al afirmar que la racionalidad usada para ordenar el mundo a veces resulta un modo insuficiente para explicar lo real (Jitrik 1970: 55).

Varios críticos han delineado los rasgos, temas y etapas de la literatura fantástica rioplatense. En general, coinciden en trazar al menos tres fases (que ya Rama había distinguido). Los precursores, a fines del siglo XIX, explotan las influencias del gótico inglés y trabajan explícitamente con el terror. Los textos de Juana Manuela Gorriti son el antecedente más citado (Verdevoye 1980; Pellicer 1986). Una segunda etapa está dada por la importancia que el esoterismo adquiere en la literatura finisecular (García Ramos 2010) y dará paso al fantástico modernista de Eduardo Holmberg y Leopoldo Lugones junto con Horacio Quiroga, quien además suma la experiencia de las 
innovaciones en las técnicas cinematográficas como material para sus relatos de espectros. Luego, las vitales innovaciones de Macedonio Fernández y Felisberto Hernández darán forma propia a los modos del fantástico tradicional. Como señala Paul Verdevoye a propósito de Felisberto cuando reviste al fantástico de la subjetividad propia de cada autor y su modo de ver el mundo. ${ }^{136}$ Jorge Luis Borges y Julio Cortázar coronan el panorama creativo del fantástico rioplatense.

El funcionamiento del fantástico en Borges, fundamental engranaje en la máquina literaria de Bolaño, ha sido estudiado por diversos críticos ${ }^{137}$, que en general destacan la posibilidad de pensar al fantástico como una superación de la mímesis realista decimonónica, extendida hasta la década del 40, que permite si no la evasión una mirada más profunda y compleja respecto de la realidad (Rodríguez Monegal 1976, 188). Para entender los usos del fantástico en Borges es preciso desentrañar qué implica lo real para el gran escritor argentino. Así, es posible vislumbrar conjeturas respecto de la realidad en un texto de Otras inquisiciones, "La nueva refutación del tiempo". Lejos de toda certeza positivista, lo real es una especie de agujero negro que pone en crisis toda teoría, toda matriz de pensamiento que intente dar cuenta del mundo. La literatura enuncia esa imposibilidad y los modos del fantástico la asumen abiertamente. Es volver a enfrentarse contra la voluntad de admitir que el desorden de lo real pueda ser capturado fácilmente por un orden discursivo, y desenmascarar la ascesis del artificio. Esta idea nos permite ver cómo las transfiguraciones del fantástico no lo contraponen a 'lo real' sino que lo integran generando lo que David Roas denomina "una transgresión del paradigma de lo real" (2011: 263).

Es aquí donde se distingue otra etapa del fantástico que -tomando especialmente como precursor a Cortázar- resemantiza los rasgos del género. Ya a principios de los ochenta, Ana María Barrenchea vislumbró un realismo que lejos del siglo XIX replantee las relaciones literatura-mundo $(1982,378)$. Si el canon mimético pareciera ser el más adecuado para documentar la experiencia de las dictaduras, el relato que se proponga explorar la opacidad de lo real-en un campo literario signado por la violencia y la

\footnotetext{
${ }^{136}$ Dice "el misterio no proviene de las cosas, sino de la visión personal del narrador, quien al describir esta visión sin explicarla nos sumerge en el misterio de su otredad" (1980: 293).

137 Mario Goloboff, por ejemplo, resume "No hay para él otra realidad que la irrealidad. Ni otra causalidad que la fantástica" (2000: 4). Por su parte, Emir Rodríguez Monegal (1976) separa al escritor argentino de toda filiación con el realismo (mágico) para esbozar una teoría de la literatura fantástica que por un lado, consciente del artificio que define al arte narrativo, elija transitar la causalidad de la magia frente a la causalidad del mundo real. Rodríguez Monegal así lo resume: "Dado el desorden del mundo real, el mundo de la ficción sólo puede tomar dos partidos: o imitarlo y caer en la simulación (es decir en la mímesis), o crear su propio orden, como lo hace la magia" (182).
} 
barbarie de la historia-exige aproximarse por otras vías. Entonces el fantástico permite nombrar lo que lo real oculta. Julio Cortázar es quien inaugura a partir de la coyuntura de los setenta la irrupción de lo social y lo político desde la lógica de lo fantástico. ${ }^{138}$ En este sentido, puede afirmarse que el fantástico en tanto modalidad contamina ciertos realismos y será entonces otro recurso eficaz para, luego de la experiencia dictatorial, procesar los traumas de la historia. ${ }^{139}$

Ahora bien ¿Por qué Bolaño se incluye en la lista que define al fantástico rioplatense? En primer lugar, en "Consejos sobre el arte de escribir cuentos" bajo la apariencia de recomendaciones Bolaño nos prescribe las siguientes lecturas: Horacio Quiroga, Felisberto Hernández, Jorge Luis Borges, Adolfo Bioy Casares y Julio Cortázar, casi el parnaso del fantástico rioplatense. En segundo lugar, Bolaño recupera del fantástico ese rasgo que Paul Verdevoye señala como común denominador, el freudiano sentimiento de lo ominoso y además puebla sus relatos de pesadillas, “fantasmas, delirios y alucinaciones". El fantástico como un modo literario, tal como lo define Rosemary Jackson, atraviesa gran parte de la narrativa de Bolaño.

\section{Testimonio y Anamnésis: Auxilio Lacouture}

Amuleto (1999) se incluye en el corpus bolañano de los relatos que narran las barbaries de las dictaduras y el fracaso de las utopías de los sesenta. Amuleto puede leerse como una carta de amor y de despedida de los ideales de los sesenta/setenta "de las hazañas heroicas de una generación entera de jóvenes latinoamericanos sacrificados" (54).

La novela desarrolla el relato autobiográfico de Auxilio Lacouture, expandiendo las diez páginas que ocupa en la novela Los detectives salvajes (1998). Auxilio se encuentra encerrada en un baño de la Universidad de México (UNAM), en 1968, para esconderse de los militares que irrumpen en el edificio quebrando la autonomía universitaria y anticipan ese suceso clave de la historia mexicana: la masacre de Tlatelolco, convertida en paradigma de todas las masacres latinoamericanas contra jóvenes "estúpidos y generosos (...) que todo lo entregan y no piden nada a cambio, y ahora de esos jóvenes ya no queda nada (...) Toda Latinoamérica está sembrada con los

\footnotetext{
${ }^{138}$ Coincidimos con Goloboff cuando afirma que "impregnado, pues, de esa nueva concepción de mundo y de la vida, habría querido también imprimir a su literatura fantástica un signo acorde con ella" (6).

${ }_{139} \mathrm{Al}$ respecto, podemos mencionar, entre otros, los trabajos críticos de Miriam Chiani sobre Marcelo Cohen, o los de Malva Filer sobre Ricardo Piglia (2000).
} 
huesos de éstos jóvenes olvidados". Como se sabe, Bolaño basa su relato en las historias que recorrían los pasillos de la universidad y los círculos de exiliados uruguayos a cerca de Alcira Soust Scaffo, una maestra uruguaya que viajó a México, conoció a Bolaño en 1970 y presenció, como Auxilio, la intervención militar desde un baño de la facultad. ${ }^{140}$

A través de un relato en primera persona, se narran los procesos de edificación y significación de una memoria traumática gestada a partir de ese acontecimiento, que funciona como paradigma y metonimia del horror latinoamericano. Aquí, Bolaño explora los modos de configuración de la memoria en dos instancias: desde el registro de los procesos históricos como representaciones en la subjetividad hasta la construcción de una memoria colectiva. Es decir, esta novela instala el problema de la memoria tanto en la esfera del individuo (Auxilio) como en el espacio de la memoria colectiva (América Latina).

Se trata de la memoria en tanto anamnesis y no mnemne: de la memoria en construcción, en movimiento, en actividad, y no de la memoria ya instalada en los imaginarios comunitarios y en los textos de la historia. Yosef Yerushalmi distingue la mnemne o memoria (aquello que permanece esencialmente ininterrumpido, continuo, igual a sí mismo) de la anamnesis o reminiscencia como "la reminiscencia de lo que se ha olvidado" (1996: 21) que, por ello mismo, precisa un proceso de elaboración, una recuperación de lo olvidado para el presente. Este sentido de un regreso al pasado (a Tlatelolco en 1968) para volver a elaborar esa memoria y traerla al presente, a fin de enhebrarla a otras memorias latinoamericanas como las dictaduras del Cono Sur, es uno de los centros de la novela. Yerushalmi describe el funcionamiento de la memoria como la retención de aquello que pueda integrarse a un sistema de valores ya reconocido por la comunidad; por ello, es canónica, compartida y necesitada de consenso. Mientras que la anamnesis designa la evocación de lo que se olvidó y, por lo tanto requiere un cambio más brusco para imponerse, precisa mover lo estatuido para instalar su propio espacio.

\footnotetext{
${ }^{140}$ Este es el testimonio de Carolina Perez Cicero, de la UNAM, que aparece en el libro de Poniatowska (1971: 70): "Durante los quince días de la ocupación del CU por el ejército se quedó encerrada en un baño de la universidad una muchacha: Alcira. Se aterró. No pudo escapar o no quiso. Al ver a los soldados lo primero que se le ocurrió fue encerrarse con llave. Fue horrible. Uno de los empleados que hacen la limpieza la encontró medio muerta, tirada en el mosaico del baño ¡Quince días después! Ha de haber sido espantoso vivir así, hora tras hora, tomando agua de la llave del lavabo. Se la pasó entre los lavabos y excusados -allí dormía, tirada en ese pasillo, en el piso del mosaico- y se asomaba de una mirilla para ver a los soldados recargados en sus tanques, bostezando o recostados adormilados en los yips ¡Era tal su terror que nunca se movió del baño!”. Ver también el artículo de Ignacio Bajter “Alcira Soust, la poeta de Bolaño en busca de la verdadera Auxilio Lacouture", Quimera: Revista de literatura, No 305, 2009, págs. 70-76.
} 
Casi a contrapelo del protagonista de Nocturno de Chile, de Sebastián Urrutia quien estaba acorralado por su incapacidad o dificultad para recordar; en Amuleto, Auxilio siente el "horror al olvido", padece la necesidad imperiosa por recordar lo sucedido. Casi como un nuevo Funes, ella está atrapada en la tarea de recordar los hechos de violencia de la historia latinoamericana. Auxilio afirma: "Yo no puedo olvidar nada. Dicen que ese es mi problema" (144). Este "horror al olvido" tiene una dimensión subjetiva e individual en Auxilio: la experiencia de Tlatelolco deviene el origen traumático que dispara ese necesidad de recordar, ese temor al olvido, esa obsesión por la memoria, por relatarla, por testificarla, por convertirla en una Amuleto que nos proteja de la violencia y conjure las repeticiones de la historia, del terrorismo de Estado.

La memoria, atrapada en ese origen traumático, apresada por el horror a perderse, se ancla en dos sitios: en el registro histórico, en el ámbito de lo real con la contundencia de lo ocurrido, con las cifras de los muertos, con la precisión del testimonio, con un "efecto de realidad". Pero también, como experiencia traumática, lo real se vuelve fantasma, adquiere aristas irreales, convoca espectros. Porque el trauma hospeda un fantasma, una zona indecible que busca decirse, un zona oculta que busca salida; y es el fantástico lo que permite traducir ese doblez, ese pliegue del trauma, ya que implica visibilizar lo que no se ve, y articular en palabras aquello que no se dice (Jackson). Además, el fantástico desestabiliza la representación realista y en este sentido es un dispositivo sedicioso dentro del relato, es lo que subvierte, altera y corrompe el ordenamiento del discurso. ${ }^{141}$

Así, la ruptura que el trauma provoca en la racionalidad de lo cotidiano puede equipararse al quiebre que introduce el fantástico en la representación realista. Amuleto tensa, entonces, la representación en el arco que va desde el grado cero de lo "real" hasta las arquitecturas de lo irreal.

Lo fantástico será, entonces, el centro del trauma pero también, y sobre todo, los fantasmas de las memorias de otras violencias de la historia latinoamericana que Tlatelolco dispara; el fantástico es el espectro de las violencias ocultas; porque "lo fantástico da salida precisamente a esos elementos que, dentro de un orden dominante realista, sólo se conocen a través de su ausencia (...) es todo lo que no se dice, todo lo

${ }^{141}$ Tal como afirma Jackson: "Esta violación de los supuestos dominantes amenaza con subvertir (derrocar, trastornar, socavar) las reglas y convenciones que se consideran normativas. En sí misma, no es una actividad socialmente subversiva (...) sí perturba, sin embargo, las leyes de la representación artística y las reproducciones de lo "real" en la literatura". (1986: 12) 
que no se puede decir a través de formas realistas" (Jackson 1986: 23). Así, en esta cita se percibe el paso desde el presente concreto de una manifestación de protesta por la caída del gobierno de Allende hacia el abismo en el cual van a caer varias de las derrotas de la izquierda latinoamericanas:

Recuerdo esa manifestación, puede que fuera la primera que se hizo en Latinoamérica por la caída de Allende. Allí vi algunas caras conocidas del 68 (...) pero también vi algo más: vi un espejo y yo metí la cabeza dentro del espejo y vi un valle enorme y deshabitado y la visión del valle me llenó los ojos de lágrimas (...) tal vez este valle solitario sea la figuración del valle de la muerte (67-68)

Este fantástico tiñe y enrarece la totalidad de la novela, mezcla espacios, fechas, eventos, personajes. La incertidumbre empaña los acontecimientos, por ello el relato de Auxilio en cierta medida no es falsable. Estas incertidumbres forman parte del proceso de construcción de la memoria en Auxilio cuya ingeniería debe más al psicoanálisis que a la historiografía; se trata más que de construir un pasado, de tramitarlo y comprender su significado.

Como ya dijimos, la novela apuesta tanto a la memoria individual y personal de Auxilio como a la colectiva. Si bien es en la subjetividad de la protagonista donde se origina y anida la configuración de la memoria, requerida por un mandato ético, luego se vincula con otros núcleos de la memoria como la dictadura de Chile a través de Belano, el nazismo y el franquismo en Pedro Garfias, León Felipe y Remedios Varo, entre otros. Se trata de invocar una zona que configure una red de memorias. En esta línea podemos retomar las reflexiones de Yerushalmi y agregar las de Metz en torno a la razón anamnética y su fuerte presencia en la comunidad judía. Yerushalmi percibe en el pueblo judío el "paradigma del funcionamiento de la memoria colectiva" (21) aun cuando todos los pueblos pueden ejercerla. Metz va más allá y reclama frente a la "razón comunicativa" de Habermas, una razón anamnética como camino posible para evitar las barbaries cuando la razón occidental fracasó. En la novela de Bolaño se persigue, como horizonte final, un recorrido por las diversas memorias cuya reunión alertaría contra las recaídas en nuevas dictaduras o terrorismos de estado. El relato, que Auxilio finalmente logra enhebrar, se convierte en un Amuleto contra las repeticiones 
de la historias, funcionaría simbólicamente como la razón anamnética. Aunque este amuleto incluye, además, una revisión y autocrítica de la izquierda revolucionaria.

Si en un primer momento las narrativas de la dictadura, y del Holocausto antes, colocaron en un lugar central al testimonio como el modo privilegiado para dar cuenta de las experiencias vividas, una nueva línea se abre dentro de las posibilidades de dar cuenta de acontecimientos límite en el marco de la crisis de realismo que en los ochenta latinoamericanos reclamaba por nuevas formas estéticas, apuntando a la puesta en duda de lo real y dando lugar lo que podríamos llamar testimonios contaminados. ${ }^{142}$ Bolaño oscila entre un discurso fuertemente referencial y un relato que atenúa las certezas de lo real y esta oscilación pareciera indicar el impacto del trauma y sus intentos por articular entre el delirio y la palabra el pasado vivido.

Un rasgo característico del relato de Auxilio, víctima de un trauma, es la incertidumbre respecto de lo real; en su discurso, el referente se disemina en tiempo y espacio: es México, Uruguay, Argentina, Chile; es 1968, pero también es 1973: "Yo llegué a México Distrito Federal en el año 1967 o tal vez en el año 1965 o 1962. Yo ya no me acuerdo ni de las fechas ni de los peregrinajes" (12) Ese fluir en el tiempo se ve interrumpido solamente por un único soporte espacial en lo real: "el lavabo de mujeres de la cuarta planta de la Facultad de Filosofía y Letras, mi nave del tiempo desde la que puedo observar todos los tiempos" (52). La experiencia de lo traumático incide de tal modo que lo vivido se repite una y otra vez, a modo de flashback.

El trauma, además, hace que lo cotidiano se vuelva monstruoso y, como ya explicamos, recubre el relato entero de elementos fantásticos, pero sin menoscabar el efecto de lo real como instancia que asegura la certeza de que Tlatelolco ocurrió. En este sentido, Miriam Chiani habla no del género fantástico sino de una modalidad (retomando a Jackson) que contamina ciertos realismos: "a mediados de los 80 [el realismo] pasa a sumar modalidades del fantástico o a él vinculadas” (2005).

\footnotetext{
${ }^{142}$ Martín Kohan sostiene que "la vuelta a lo real (...) no presupone para nada la confianza y las certezas que el realismo garantiza" (2005: 34). Por lo tanto, el modo de acercarse a ella permite estrategias que atentan "contra los códigos admisibles de la verosimilitud pero no contra la ilusión referencial". Cfr. Miguel Dalmaroni cuando analiza precisamente una novela de Kohan en La palabra justa (163). Ver también la introducción de Sandra Contreras, "Realismos. Jornadas de discusión”: “¿pero no es posible extraer de una teoría lo que nos puede hacer pensar hoy, en nuestras coyunturas? ¿y no es ésta la más potente lección de Lukács: a nuevas coyunturas -nuevas realidades-, formas nuevas?” en Boletín/12, p. 10 .
} 
Para pensar las funciones del relato, Roland Barthes en "El efecto de lo real" analiza lo que Jakobson denomina significación D del realismo: ${ }^{143}$ la introducción de rasgos inesenciales en la descripción para crear un efecto de realidad. ${ }^{144}$ La descripción, dada su estructura sumatoria, carece de justificación lógica; sin embargo, Barthes señala también que todo en el relato es significativo (145), aún las "zonas de relleno". Si nos detenemos en un análisis estructural de la funcionalidad de la catálisis y del indicio en Amuleto, veremos que la descripción de un objeto nimio, en lugar de provocar el barthesiano "efecto de lo real", dispara un "efecto de lo siniestro" -que permanecía oculto detrás de lo "real". Veamos cómo el florero funciona en la siguiente escena, cómo se transforma de un objeto "aparentemente tan inofensivo" en "el infierno o una de sus puertas secretas" (15):

(M)e acerqué al florero y lo observé desde distintos ángulos y entonces pensé: voy a meter la mano por la boca negra del florero (...) y vi cómo mi mano se despegaba de mi cuerpo, se alzaba, planeaba sobre la boca negra del florero (...) y justo, entonces, una vocecita en mi interior me dijo: che, Auxilio, qué hacés, loca (...) y mi mano quedó colgando, en una posición como de bailarina muerta, a pocos centímetros de esa boca del infierno (...) Y cuando estuve a medio metro me dije: si no el infierno, allí hay pesadillas, allí está todo lo que la gente ha perdido, todo lo que causa dolor y lo que más vale olvidar (16)

En este ejemplo, el efecto de lo real es contaminado por un impulso de lo fantástico que desrealiza al objeto, muestra lo ominoso que puede ocultar, revela sus vísceras. Si Barthes define a los indicios como unidades integradoras que contienen información acerca de la identidad de caracteres o de una atmósfera particular; en cambio para Auxilio, toda descripción de objetos termina por diluir las fronteras entre 'la realidad' y sus sueños o sus alucinaciones, creando así la atmósfera equívoca, ambigua, dual de lo ominoso.

Así, los límites de lo real se estiran, se diluyen por medio de catálisis e indicios que evocan una desviación del orden de lo dado -o la posibilidad de un "otro real" que la inestabilidad de la voz narradora parece querer aprehender. Hay momentos -los más

\footnotetext{
${ }^{143}$ Jakobson se refiere al procedimiento de "condensación del relato" (p. 171)

${ }^{144}$ Ver De Diego, José Luis, "El nuevo verosímil", en AAVV, La escritura en escena, Corregidor, Bs As, 1994.
} 
viscerales en los que el relato cruza brutalmente lo "cotidianamente real" con la experiencia de lo traumático. Como si la imposibilidad de narrarlo exigiera la más ingenua de las creencias: la capacidad del lenguaje para referir los significados, para describirlos (Auxilio suele emplear una lengua transparente y referencial para narrar los momentos más críticos). Porque para Auxilio Lacouture lo cotidiano es convivir con el horror: "todo ha acabado, los granaderos se han marchado de la Universidad, los estudiantes han muerto en Tlatelolco, la Universidad ha vuelto a abrirse, pero yo sigo encerrada en el lavabo de la cuarta planta" (128).

A lo largo del texto aparecen claves para definir cómo esta propuesta estética de Bolaño se apoya en la reescritura, el desplazamiento, la dilatación. Aunque Auxilio afirme que "a mi me enseñaron (con un látigo me enseñaron, con una vara de fierro) que las redundancias sobran y que sólo debe bastar con el argumento" (11), su relato laberíntico parece suspenderse en lo elíptico, por unos momentos alucinatorio, por otros, repetitivo; como si la percepción socavara toda coordenada temporo- espacial para abrir nuevas aproximaciones a lo real.

Como se mencionó anteriormente, Amuleto es la expansión del texto aparecido en Los detectives salvajes y comienza anunciando un crimen atroz:

Esta será una historia de terror. Será una historia policíaca, un relato de serie negra y de terror. Pero no lo parecerá. No lo parecerá porque soy yo la que lo cuenta. Soy yo la que habla y por eso no lo parecerá. Pero en el fondo es la historia de un crimen atroz. (11)

Auxilio, desde un principio se asume con otra autoridad como narradora lejos de la claridad y transparencia de quien debe testimoniar y deja fluir un relato anclado en el trauma que dilata, que deja una historia pendiente, a la deriva, para retomarla de vez en cuando y contarla al final; es la historia de los jóvenes latinoamericanos que "caminaban indefectiblemente hacia el abismo" (152).

Los saltos en el tiempo, los diferentes lugares, las historias intercaladas, los personajes que desaparecen del relato son los pliegues que la voz de Auxilio concatena a partir de la contingencia de lo real. La experiencia traumática no se articula a partir de 
certezas, de relaciones lógicas ni de sentidos unívocos. ${ }^{145}$ Auxilio explica: "mi forma de desplazarme hacia el objeto observado era como si trazara un espiral" (16). Este procedimiento fantasmiza lo narrado y hasta las identidades se desvanecen. El relato abunda en la ficcionalización de figuras 'reales' asediadas por un halo borroso, como las pinturas de Lilian Serpas, "figuras (....) muy delgadas, parecían enfermas, volaban o estaban enterradas (...) se llevaban un dedo a los labios indicando silencio" (111).

En la casa de los melancólicos Pedro Garfias y León Felipe, Auxilio limpia el polvo "que todo lo pulveriza" (15); tiene un encuentro onírico con Remedios Varo ya muerta; otro, con el fantasma de Lilian Serpas "la única indemne en esta historia, porque ella ya lo ha sufrido todo" (108). Todas estas figuras comparten la experiencia del exilio o han sufrido las consecuencias de gobiernos totalitarios o la locura. ${ }^{146} \mathrm{Y}$ sin embargo, cuando se trata de narrar los hechos que disparan la historia, el discurso se vuelve descriptivo, referencial, testimonial:

Yo estaba en la Facultad aquel 18 de septiembre cuando el ejército violó la autonomía y entró en el campus a detener o a matar a todo el mundo. No. En la Universidad ni hubo muchos muertos. Fue en Tlatelolco. ¡Ese nombre que quede en nuestra memoria para siempre! (28)

Como señala Dalmaroni en su análisis de la Revista de Crítica Cultural, la recuperación de un sentido reconocible se instala en el discurso. Hay una ética que no puede negociarse. El referente estalla y se disemina pero tiene un anclaje concreto sobre el que siempre debe volverse: el horror. Entonces aparece el "Yo lo vi. Yo doy fe" de la narradora y su vocación testimonial.

Sin embargo, Bolaño se corre de los géneros canónicos que han vehiculizado la cuestión de la memoria a partir de las posdictaduras en el Cono Sur; es decir, el testimonio y la novela histórica como géneros funcionales a la reconstrucción y las significaciones de la memoria. En América Latina, el privilegio de ciertos géneros sobre

\footnotetext{
${ }^{145}$ En el capítulo X de Mimesis, Auerbach analiza la narrativa de Virginia Woolf y sugiere que una narración orientada a un telos es un artificio, la experiencia no funciona así: es acumulativa, asociativa, azarosa.

${ }^{146}$ Pedro Garfias, poeta (1901-1967): Exiliado en México, miembro del PC español durante la República, pasó por los campos de concentración franceses. León Felipe, poeta (1884-198). También se exilia en México perseguido por el gobierno de Franco. Remedios Varo, pintora (1908-1963). Emigra a México cuando los nazis invaden Francia. Lilian Serpas, poeta (1905-1985) Nace en El Salvador, vive en los Estados Unidos y en México donde enloquece, sumida en una pobreza extrema.
} 
otros ha respondido a la constante tensión entre valores estéticos e ideológicos en determinadas coyunturas históricas.

Durante los sesenta la Revolución cubana se convierte en un polo que reordena en torno a su centro las propuestas literarias y el rol del intelectual, dando lugar a dos tendencias hegemónicas en el campo de la literatura latinoamericana: por un lado, la novela del boom que explora los signos de la identidad latinoamericana en sus variados registros, que indaga tanto las marcas de la violencia como las dimensiones utópicas presentes en su historia, en sus imaginarios y que defiende la autonomía del arte ante las presiones del calendario político, que eligen estéticas en las que las representaciones de los escenarios locales se articulan con procedimientos vanguardistas. Por otro lado, desde la ciudad letrada revolucionaria (en Cuba) se institucionalizan determinados géneros literarios considerados adecuados para vehiculizar lo político-revolucionario exigido por el nuevo escenario: la poesía conversacional, el testimonio, la canción de protesta y el cine documental serían los géneros privilegiados, configurando otro polo estético en tanto traducen la realidad a partir de la estética del realismo socialista y de los géneros fuertemente referenciales (Gilman 2002). A partir de las dictaduras del Cono Sur, éstos géneros se refuncionalizan, ya no para narrar el compromiso revolucionario de los sesenta, sino para dar cuenta de una experiencia determinada por el horror, la pérdida y el trauma.

En Chile, a partir del 1973, el género testimonial resulta el modo narrativo más adecuado para denunciar los excesos del régimen pinochetista; mayoritariamente escrito desde el exilio, se centró en las experiencias traumáticas del presidio político. Podemos mencionar, entre otros, a: Jamás de rodillas (Moscú, Editorial de la Prensa Novósti, 1974) de Rodrigo Rojas; Prisión en Chile (México, Fondo de Cultura Económica, 1975) de Alejandro Witker; Cerco de púas (La Habana, Casa de las Américas, 1977) de Aníbal Quijada Cerda; Testimonio de un destierro (Santiago, Mosquito Editores, 1992) de Jorge Gilbert; El infierno (Santiago, Editorial Planeta, 1993) de Luz Arce. Entre otras cuestiones, el testimonio obedece a la necesidad de representación, es decir, a partir de la experiencia traumática el yo que narra necesita constatar que su conciencia no ha sido destruida y que posee la capacidad de relatar su experiencia, negándose a aceptar la derrota.

También el testimonio es una vía de denuncia, apela a la verdad, a la demanda de justicia, funciones que se fortalecerán en los noventa. El relato es un elemento de prueba para establecer una verdad a contrapelo de la historia oficial. Es la voz de los 
vencidos que, para Avelar, no han incorporado una reflexión sobre la derrota. Más bien retoman el discurso de una resistencia heroica sin advertir que "la recopilación de datos no es aún la memoria de la dictadura. La memoria (...) requiere otro lenguaje” (Avelar 2000: 92). Hacia 1968, la polémica entre realismo y vanguardia enmarcó la discusión por la eficacia comunicativa y la eficacia estética de la obra de arte (Gilman 2002: 335). Así, el auge del realismo testimonial institucionalizado en 1970 por Casa de las Américas se instaló acompañando la radicalización política del campo intelectual. Antes de verlo como un paso hacia atrás (volver a lo prescriptivo de estéticas caducas) se incorpora al mandato de acompañar los nuevos procesos políticos y sociales revolucionarios. Por su parte, Mabel Moraña (1997) ofrece un completo panorama del testimonio apelando a los cambios, la apertura y los cuestionamientos que el mismo activa al interior de la serie literaria.

Por otro lado, la cuestión del realismo en Chile no se ha separado de una tradición clásica dentro de la cual surge la problemática del testimonio, y el debate de sus modos y funciones se enmarca en una necesidad de crítica y denuncia (Quezada 2010). Aquí el realismo pone a funcionar una forma de testimonio y también -como señala Analía Capdevila en su artículo "Realismo, memoria y testimonio"- "una política de la memoria" (2009: 136). El problema surge cuando se obturan las posibilidades de una estética realista al identificarla con un "realismo protocolar voluntario, sobriamente verosímil, austero (...) una suerte de ascesis para conjurar la tragedia o la exaltación reivindicativa y épica de la consigna" (Capdevila 2009: 143).

Amuleto cruza la necesidad referencialista del testimonio con la presencia del fantasma, lo que la distancia del testimonio de denuncia para explorar aquello que el género en su versión más protocolar no da cuenta, lo que el testimonio en tanto representación no puede traducir: los fantasmas, las incidencias del horror en el presente. Más que un testimonio se trata de una vocación testimonial que hace del realismo visceral, del realismo fantasmático de Bolaño, un modo de cuando reflexionar sobre cómo poner en narración experiencias traumáticas que ya exceden lo personal, se inscriben en lo social y por lo tanto se construyen como memoria. 


\section{Relatos de horror, relatos fantásticos (Llamadas telefónicas)}

En los cuentos de Bolaño también se percibe este cruce entre una pulsión referencial que procura anclar los relatos en los escenarios de la dictadura y una pulsión por lo fantasmático que explora lo siniestro en clave fantástica. Nos detendremos en dos relatos de Llamadas telefónicas, que como hemos visto reúne cuentos en los que la derrota, el fracaso o la frustración se conjugan con la dispersión y la pérdida de un rumbo definido.

Los relatos están poblados de espectros marcados por la melancolía, son sus personajes que aparecen dislocados, ajenos, perdieron su lugar en el mundo y carecen de contención alguna; los valores que sostuvieron las generaciones precedentes se agotaron o fueron destruidos; su vida es una sucesión de derrotas y si tuvieron un pasado, el presente es nada, un continuum hacia la decepción y el fracaso (como los ideales revolucionarios de los jóvenes de la década del setenta). Ya en el comienzo, se nos advierte el tono que permeará las historias y nos involucra, desde el epígrafe de Chejov: “¿Quién puede comprender mi terror mejor que usted?”. Así, cuentos como "Sensini", "Detectives", "Compañeros de celda" o "Clara" no solo mencionarán -a veces temáticamente, otras tangencialmente- la asfixia dictatorial o los sistemas totalitarios (como en "Henri Simon Leprince" u "Otro cuentos ruso") sino sus herencias, su "después", desde una estética que no reniega de los modos realistas pero los transfigura para incorporar las nuevas aristas de la realidad.

En las historias donde nos detenemos en este capítulo, el fantástico, sus procedimientos y temas, es lo que funciona como matriz narrativa y logra dar cuenta de la impronta que la historia reciente ha marcado en la literatura latinoamericana de los últimos años. Respecto del fantástico, las apariciones fantasmales constituyen el rasgo fundamental que Bolaño explota para iniciar sus mecanismos.

"Detectives" y "Compañeros de celda" muestran cómo la lógica del fantasma es también la lógica del fantástico que se filtra en los modos de armar el relato que aparenta anclarse firmemente en lo real (en el registro de las biografías o el tono coloquial, por ejemplo) para abrir zonas oscuras que atrapan al lector y lo conducen al vacío, a la nada. Los relatos se fundan en un movimiento continuo, en desplazamientos que cortan, expanden algo que está a punto de estallar, y nunca sucede. La matriz del género fantástico es entonces otro de los modos a los que Bolaño apela para dar cuenta 
de las zonas de lo inefable que parece acechar constantemente y enuncia las consecuencias de una experiencia que en los casos que analizaremos está ligada a la violencia histórica.

"Compañeros de celda" cuenta la historia de Sofía, con quien el narrador tiene una extraña relación amorosa. El punto de partida (en el título y en el primer párrafo) es la experiencia carcelaria que los une en tiempo (noviembre de 1973) pero no en espacio (él padece la dictadura de Augusto Pinochet en Chile y ella, la España franquista). Este dato no es menor y desde un principio perturba las leyes de lo aceptado y conocido: ellos fueron "compañeros" de una experiencia pero no compartieron el espacio físico que el lector imagina a partir del título. Y si Borges formulaba una pregunta -"Esos instantes que coinciden ¿no son el mismo?” (1952: 368)-, Bolaño la ratifica. Esta repetición de ecos borgeanos no solo desbarata y confunde la serie del tiempo (368) y elimina la noción misma de espacio, sino que se estrella ante lo concreto de la experiencia traumática que significó la cárcel para ambos personajes. Cualquier conjetura sobre el azar o las prescripciones del tiempo y el espacio se torna fútil y poco esclarecedora. Así lo intuye el narrador de Bolaño:

A veces me imaginaba a Sofía en la cárcel, en Zaragoza, en noviembre de 1973 y me imaginaba a mí, detenido durante unos pocos pero decisivos días en el hemisferio sur, por las mismas fechas, y aunque me daba cuenta de que ese hecho, esa casualidad, estaba cargada de significados, no podía descifrar ni uno. Las analogías solo me confunden. (Bolaño 1997: 142)

El foco será entonces la presencia cada vez más volátil, lejana de Sofía. Las huellas de su experiencia en el encierro se vuelven visibles a través del relato del narrador, también víctima, y a partir de la lógica del fantástico. Los rasgos que la definen reiteran la fragilidad y el misterio que rodean su figura. Las marcas de su deterioro físico se infieren de su escasa alimentación y una enfermedad que pareciera ser mental, ella misma decía que estaba enloqueciendo (137-138).

El quiebre en el relato se manifiesta cuando el narrador afirma: "Sofía, por entonces, era un fantasma" (142). Su condición espectral ya se anunciaba en los comentarios sobre los encuentros sexuales con el narrador, "una lucha interminable hasta quedar vaciados" (140), en los que el cuerpo de Sofía se parece a un objeto con "el 
alma en otra parte" (141), cada vez más ausente, más sepulcral ${ }^{147}$. Los dos estados que definen a Sofía, la locura y lo fantasmático, señalan una ausencia y revelan los despojos de un trauma. Parecería como si los ecos de la prisión persiguieran la cotidianidad de Sofía hasta confinarla en el interior de su casa, lúgubre, oscura y silenciosa, donde el narrador la encuentra después de varios meses, desnuda y extremadamente delgada y vuelve a sentir esa cercanía imposible como aquella coincidencia de 1973 (o tal vez, su consecuencia) ${ }^{148}$.

Pero esta vez el efecto que Sofía provoca, lejos de volver a unirlos, desconcierta al narrador y lo perturba. Es entonces cuando el misterio en torno a Sofía aumenta así como también crece la tensión en el relato, con la mención de "monstruos, de conspiraciones, de asesinos" (144) y el evento que protagoniza Emilio (el militante comunista ex esposo de Sofía) a quien ella intenta matar. Esto es lo que le cuenta Nuria (actual pareja de Emilio) al narrador, quien siente el impulso de volver a ver a Sofía. Los encuentros subsiguientes continúan con el tono desafectado de las descripciones los retazos de juventud de un sudamericano pobre, en España, entre intelectuales y militantes comunistas, anarquistas o feministas radicales (139)-, matizado con ese impulso de lo fantástico que se insinúa pero a la vez decepciona. Porque si la casa de Sofía, limpia, oscura y vacía es casi una espacio sepulcral -su misma dueña está "helada como una muerta" (147) - el encuentro final con el narrador termina con una cena en una pizzería. El relato del narrador antes plagado de incertidumbres o titubeos (como si el recuerdo le costara) estrepitosamente nos coloca en el marco de una relación común, hasta banal, entre amigos: "Después nos vestimos y salimos a cenar a una pizzería" (147). Fin del cuento. Esa presencia espectral que ensombreció el relato de repente se esfuma junto con todos los mecanismos del género antes activados.

El uso del fantástico, entonces, no alcanza para que el cuento cristalice en una clasificación genérica cerrada. Sino que dispara la tensión, la incertidumbre generando un ambiente ominoso que se filtra por las grietas de la historia narrada. La sensación de un misterio aún no develado se instaura e invade personajes, los lugares cotidianos y comunes de modo que todo adquiere una lógica siniestra que no conduce a nada, pero permanece como suspendida en los finales abruptos. En la reescritura que Bolaño

\footnotetext{
${ }^{147}$ El siguiente pasaje lo manifiesta: "Todo su cuerpo ardía, se arqueaba, como un trozo de metal al rojo vivo, pero sus lágrimas eran tan solo tibias y al bajar por su cuello o cuando yo las recogía y untaba sus pezones con ellas se helaban" (Bolaño 1997: 141).

${ }^{148}$ Como si fuese su doble, el narrador percibe a Sofía "en una situación tal de desamparo que en lugar de empujarme hacia ella me enfrió como si las consecuencias de su desnudez las estuviera sufriendo yo" (Bolaño 1997: 143).
} 
realiza de esta tradición estética, el efecto no es la sorpresa o la incertidumbre, ni el horror, sino el vacío, la decepción, son los "silencios" que para Rosalba Campra (2008) el fantástico moderno introduce.

El cuento "Detectives" resulta otro ejemplo significativo. A diferencia de otros relatos, aquí se explicita, dramáticamente, el hecho bisagra que aparece sesgado en el resto de las historias: la dictadura militar. A través del diálogo puro, como al paso, dentro de una conversación para matar el tiempo durante un viaje en auto, dos ex militares reconstruyen el pasado en tiempos de Pinochet. El tono prosaico y vulgar de sus voces se vuelve cada vez más alejado de los temas que abordan, armando una oscura red de sentidos: armas blancas, patria, silencio, muertos, violaciones. La charla se ancla en 1973 y el recuerdo es elocuente: “Allí los matamos a todos” (Bolaño 1997: 121). Una de las voces, la del que pareciera el más tonto, Arancibia, expresa un pensamiento lineal, acrítico; el otro -Contreras- parece ser más reflexivo, por momentos hace sospechar un sentimiento de culpa, de remordimiento. Es cuando recuerda la detención de Belano que su registro cambia y aparece el miedo. La escena del espejo, en el cual se miran pero no se reconocen, es el más claro ejemplo de los dobleces funestos que estos detectives encarnan:

... me miré y vi a alguien con los ojos muy abiertos, como si estuviera cagado de miedo, y detrás de esa persona vi a un tipo de unos veinte años pero que aparentaba por lo menos diez más [...] vi un enjambre de jetas, como si el espejo estuviera roto, aunque bien sabía que no estaba roto. (Bolaño 1997: 132)

Retomando a Freud, Jackson resume lo siniestro en su doble significado de “descubrir lo que está oculto y así transformar lo conocido en desconocido" (1986: 65); solo así puede expresarse el horror de la experiencia carcelaria y los efectos que provoca en Belano (y en su antiguo compañero de liceo, ahora militar).

Sin embargo, este efecto siniestro se diluye rápidamente cuando volvemos al marco de la anécdota: la descarada charla, acrítica, de dos detectives impunes. Por eso, al final, ya clausurada la modalidad del fantástico, los detectives asumen la posibilidad el asesinato ("me pasó por la cabeza la idea de sacar la pistola y pegarle un tiro allí mismo"), pero luego se retractan y optan por la propia absolución: "Nosotros no hacemos esas cosas" (Bolaño 1997: 133). 
Al esparcir estas astillas de espectros, pesadillas y dobles fantasmales, Bolaño no solo recupera una tradición sino que la vuelve a inscribir en una zona geográfica reconocible, aunque expandida. No escribe cuentos fantásticos, pero introduce la modalidad del fantástico para permear el relato con las voces -silenciadas- del horror que muchos conocieron y pocos pronunciaron. Es así como el impulso testimonial hacia lo real aparece trasformado. 


\section{Monsieur Pain o el "documento fantástico"}

Hoy sufro suceda lo que suceda. Hoy sufro solamente.

César Vallejo

En esta articulación de una vocación testimonial contaminada por el fantástico la novela Monsieur Pain da un paso más allá y propone una etiqueta, la del "documento fantástico", para dar cuenta de ese nudo problemático que Bolaño utiliza para indagar lo real. Con ello apunta a descubrir los dobleces de una realidad cuya superficie sólo delata otras capas que es necesario sondear. Así, hemos destacado cómo Bolaño rearma ciertas zonas de la tradición latinoamericana ligadas al testimonio, lejos del protocolo genérico, para fraguar nuevas formas de anclar lo real en el relato. El eje vertebrador de estas narrativas se constituye en la búsqueda del escritor por recordar, por recuperar a través de temas y procesos un pasado y poder traducirlo en palabras y en escritura. En Monsieur Pain hay diferentes zonas oscuras que junto con tres espacios bien definidos se constituyen como inmersiones al pasado y convocan sus fantasmas. También esta búsqueda de la memoria y puesta en palabras se articula en las diferentes encarnaciones que figuran al escritor: está Vallejo, por un lado y Pain, el mesmerista por el otro. Este último propondrá otro tipo de recuerdo que desviándose del testimonio sea capaz de trabajar con el pasado: es tarea de un mesmerista el diálogo con los fantasmas. En ambas figuraciones el proceso está atravesado por la melancolía, primero hablar, luego recordar y por último, escribir.

Monsieur Pain, la novela de Roberto Bolaño que la editorial Anagrama publica en 1999, nace con el título La senda de los elefantes en 1981 o 1982, como el mismo autor explica en la "Nota preliminar". Es una novela de los comienzos por dos razones. Forma parte de los inicios de Bolaño como escritor que intenta profesionalizarse entre concursos y "premios búfalo que un piel roja tenía que salir a cazar pues en ello le iba la vida" (12). También se constituye como una novela de los comienzos en el sentido que desarrolla Edward Said en Beginnings. Intention and Method. Monsieur Pain condensa temas, tonos, intenciones que Bolaño retomará y desplegará en narrativas posteriores. En esta novela se anuncia y da nacimiento al escritor melancólico de los noventa y se 
crea un precursor: el escritor derrotado, el héroe fracasado de la lucha republicana, en el melancólico César Vallejo. Bolaño se pregunta sobre la condición del escritor luego de la derrota del gobierno de Allende, para ello la novela convoca la Guerra Civil española y anticipa el nazismo que asolará a Europa. La relación de Bolaño con la historia de la literatura latinoamericana -y con la historia a secas- es una preocupación constante. El tono melancólico, contra el "entusiasmo" de las narrativas revolucionarias será nuevamente el hilo conductor, síntoma de un campo literario signado por la violencia y la barbarie de las últimas dictaduras latinoamericanas.

Leer Monsieur Pain como texto de los comienzos a la luz de otros textos del autor chileno supone un volver atrás, como "el primer paso en la producción intencional de sentido" que se descubre a posteriori. Es decir, para un análisis de esta novela como texto de los comienzos es necesario primero la lectura de las novelas y cuentos que siguieron en el tiempo a Monsieur Pain y conforman un proyecto creador que interviene en el contexto de debates en torno a las herencias de las últimas dictaduras en el Cono Sur. También nos permite ver a Pain como un proto alter ego que luego cambiará por Belano.

La trama temporal, de la enunciación al enunciado, evoca la pérdida de la utopía occidental en el siglo XX. Se inicia la intriga con una misión que el mesmerista Pierre Pain debe cumplir por pedido de su amiga Madame Reynaud: utilizar sus conocimientos de acupuntura y pases de energía para curar a un enfermo sudamericano, desahuciado, que agoniza sin una explicación lógica, “¡Todos los órganos son nuevos! ¡Ojalá que encontráramos uno en mal estado! Veo que este hombre se muere, pero no sé de qué" (59), asevera el eminente doctor Lemiére. César Vallejo agoniza y su única comunicación con la realidad reside en el constante hipo que parecía llenar de agujeros el silencio (62). Lo extraño del caso se acentúa cuando Pain, antes de tomar una decisión sobre el asunto, recibe la visita de dos españoles de aspecto sospechoso que lo sobornan para olvidar el tema y dejar todo en la nada. Así, se inicia un nebuloso recorrido en el cual Pain intentará confesarle su amor a Madame Reynaud, salvarle la vida a Vallejo y descubrir por qué quieren impedírselo. Su relato nos lleva por un camino que parece armado de pasillos laberínticos, lluviosos, oscuros, solitarios, entre el delirio, los sueños y lo real hasta concluir en el fracaso profesional y personal. Una derrota que, enmarcada en un contexto tumultuoso, figura las derrotas históricas que han sufrido varias generaciones durante el siglo XX. 
La novela comienza entonces ubicándonos en tiempo y espacio: París, 1938, precisamente un miércoles lluvioso de otoño, 6 de abril, al atardecer. Estas marcas temporales -y climáticas- van a hilar todo el texto como constantes de una trama que se figura caótica, entre misteriosa y delirante. El relato en primera persona abarca el mes de abril, bajo la lluvia infinita, en una ciudad vacía y gris. Un espacio urbano desolado y amenazante, tan cerrado como los otros espacios de la novela, por ejemplo el cine, el almacén de trastos inútiles y la clínica, por los que el personaje y narrador Pierre Pain transita intentando resolver el enigma al que lo han arrojado su joven amiga Madame Reynaud, Georgette Vallejo y un grupo de españoles sombríos y que parecen recién salidos de la cárcel o de un sótano (20). Son diversos elementos los que, reiterados a lo largo del texto, le dan al mismo una cadencia monótona, una atmósfera sombría. Nos introducen en la melancolía misma y, a la vez, nos mantienen alerta, con la extraña sensación de que algo raro va a suceder.

\section{Los lugares de la memoria y "lo real fantástico"}

Pierre Pain atraviesa tres experiencias de la memoria; cada una en un espacio diferente. Estos lugares devienen zonas de búsqueda y revelación y, en el cruce entre lo real y lo onírico, invocan a los fantasmas del pasado de Pierre Pain, que constantemente reaparecen en sus pesadillas. En primer lugar, está el cine con toda la simbología que acarrea en tanto cámara oscura que permite ingresar a la interioridad del sujeto para ver, a través de la iluminación. Luego hay un almacén de trastos viejos que implica un volver al pasado en tanto depósito y además tiene forma de laberinto. Y por último, también como un laberinto, está la clínica como el lugar del escritor (César Vallejo está internado allí) envolviendo a la escritura con las signos de una terapia.

La sala cinematográfica es la más significativa pues el episodio en el cine es una puesta en abismo del eje de la novela. El cine concentra características que comparten los otros espacios: una oscuridad que parpadea por la iluminación irregular de la pantalla, y la sensación de que algo extraño puede ocurrir (“.(..) el acomodador carraspeó al pasar junto a mí, como si pretendiera advertirme de algo fuera de lo normal", 120). Pain llega a la sala cuando persigue a uno de los españoles y se encuentra con un viejo mesmerista conocido, Pleumeur-Bodou, devenido fascista. La película que están proyectando, titulada Actualidad, reúne un relato ficcional en torno a 
las peripecias del personaje Michel y el fragmento de un documental sobre un grupo de estudiantes en un laboratorio, constituyendo un "híbrido de documental" (128). Es "una historia de amor y ciencia" (116), cuyos diálogos remiten a la cuestión de la memoria, en una trama donde las nuevas promesas de la ciencia ensayan algo relacionado con la radioactividad, luego ocurre una explosión y se desata un asesinato en masa fríamente planeado (130). En Michel hay un pasado oscuro, una culpa que lo oprime aunque él exprese su inocencia; ha padecido una experiencia traumática y está atrapado entre el olvido y las pesadillas: "Durante el día la amnesia es como el desierto. Durante la noche es como la selva, poblada de fieras salvajes" (121). Se plantea también el problema de la identidad articulada al recuerdo, "La pesadilla es el pasado, la memoria; para olvidar tendría que ser otro" (122). Alternado con la historia de Michel, el documental sobre el grupo de jóvenes científicos tiene como participante a Terzeff, un viejo amigo de Pain. Así, Pierre Pain ya no es un mero espectador, hay una parte de su propia historia que aparece en la pantalla, algo que tiene que ver con su pasado. Después de asistir al cine, Pain enfrenta a Pleumeur-Bodou. El entonces amigo es ahora colaborador nazi y se jacta de utilizar la técnica del mesmerismo como instrumento de tortura. Como en el film, Pain también se encuentra atrapado en las tramas de la memoria, en un recuerdo oscuro que no logra despejar. Sin embargo, por primera vez decide toma una posición activa y le arroja una copa a la cara, continuando, así, el camino de saldar deudas con su pasado. Este será su único acto.

La película, entre la historia de Michel y las imágenes de los científicos, es entonces un "documento fantástico" (126), un "híbrido de documental” (128) así como el relato de Pierre Pain es un cruce entre la voluntad de testimoniar y la presencia de lo fantástico. También en este sentido Actualidad condensa su propio relato. Los recuerdos de Pain permanecen atrapados en la experiencia traumática de la Gran Guerra, que sin ser explícita retorna en sus pesadillas. Su narración se ancla en dos sitios, por un lado en el registro de los acontecimientos, en el ámbito de lo real, con la necesidad de expresar con detalles todo lo que sucede durante el mes de abril, por París, en un otoño lluvioso. Esa voluntad de testimoniar se exhibe en la constante y prolija referencia a fechas y horas. Las fechas y horarios, casi como las entradas de un diario o un registro, se reiteran con la frágil confianza de dar verosimilitud al relato, por ejemplo "la noche del 7 al 8 de abril" (53), "a las tres menos cinco de la tarde" (91) "a partir del lunes 11 de abril" (150), etc. A esto se le suma el "Epílogo de voces" que, como un diccionario biográfico, informa los destinos de los personajes involucrados en la novela. 
Asimismo, todo su relato está impregnado de visiones y pesadillas. Hay una zona indecible que busca decirse, una zona oculta que busca salida en los pliegues de la memoria y es el elemento fantástico el que permite traducir ese doblez, ya que implica hacer visible lo que no se ve, articular lo que no se dice. El fantástico, como hemos señalado, opera como un dispositivo sedicioso dentro del relato, es lo que subvierte, altera, corrompe el ordenamiento del discurso y, como afirma Rosemary Jackson perturba "las leyes de la representación artística y las reproducciones de lo "real" en la literatura" (1986:12)

Este cruce entre ficción y realidad caracteriza la narrativa de Roberto Bolaño. Personajes y hechos reales se fusionan con un mundo ficticio, juntos conjuran nuevas lecturas de lo real. Hay una voluntad testimonial que pugna por reponer la violencia latinoamericana y otros horrores de la historia (aquí está la Europa fascista y nazi), pero esta pulsión por lo real está constantemente amenazada por los fantasmas que la misma barbarie provoca, sus huellas, sus vacíos, sus silencios.

Los pasajes oníricos del relato de Pierre Pain siguen los modos del guión cinematográfico (hay escenas, primer plano, bastidores), imprimiendo una sensación de realidad simulada en un constante vaivén en el que Pain oscila entre realidad y ficción. Además, esta zona paraxial entre pasado y presente, entre lo real y lo onírico está habitada por la imagen de un desconocido. “¿Quién es ese hombre? ¿qué busca?” (54) se pregunta. Es alguien que acecha, cuya presencia se percibe en todo el texto a través de los guiños del relato a la novela de espionaje. En una de sus pesadillas hay un "jefe", "agentes" (54) que se identifican con los españoles que persiguen y vigilan a Pain y a Vallejo.

Otro espacio revelador (junto con el cine) es el almacén industrial, cuyos pasillos convergían en el centro cual laberinto (101). Allí, en ese espacio que almacena, se pone de manifiesto un dolor (pain) interno que pugna por emerger; un otro que hace que Pain ya no sea el mismo. Después de un confuso episodio en un prostíbulo, donde lo invitan a presenciar un acto de pornografía (con elementos de un ritual de magia negra) que Pain rechaza, aparece en el almacén. Casi a oscuras, se encuentra atrapado en un depósito de herramientas y trastos viejos que lo inquietan: "en el ambiente flotaba algo que no hacía presagiar nada tranquilizador" (100). No encuentra la salida y decide pasar la noche en esa suerte de cementerio de lo que alguna vez fueron herramientas de trabajo. Se acomoda en una bañadera, como si fuera un ataúd (103), comienza a escuchar un sonido que recorre los espacios -“de pronto el ruido se despegó de la pared 
y empezó a abrirse paso entre los cachivaches" (103)- hasta materializarse primero en pasos, luego en una sombra con hipo. El dolor que siente en el cuerpo es producto de su postura en la bañera, con una fuerte marca simbólica: es la inmovilidad misma, esa incapacidad de actuar, o de hablar, que tanto acosa a Pain ("En dos ocasiones intenté levantarme, en ambas resbalé, como si el destino no quisiera dejarme correr el más mínimo riesgo", 105). Otra vez, lo bloquean la pasividad y las imágenes de "fugas y decepciones" (105) que asedian su presente. Cuando despierta, su actitud cambia y decide terminar con algo, "se acabaron las calesas que no van a ninguna parte" (106). Entonces llama a su viejo amigo monsieur Rivette, siguiendo "impulsos desconocidos. Sentía una cólera vaga, una ligera sensación de estafa que poco a poco, como un taxidermista, me iba acorazando por dentro”. (109) Aquí reitera la decisión de actuar y, como ocurrió luego del cine frente a su ex colega Pleumer-Boudou, tiene que ver con otro vínculo del pasado -en este caso, Rivette.

El desconocido ¿era la silueta de Vallejo o la suya propia que lo acechaba desde el pasado? ¿de quién era el hipo insistente, esa voluntad afásica de la palabra atragantada? La clave aparece luego en la conversación que sostiene con Rivette. Aquí hay algo del pasado que tiene que resolverse pues, sin dejar en claro qué fue lo que sucedió entre ellos, hay indicios de una situación traumática que padeció con su grupo de amigos, “¿por qué pienso en ellos? (...) son como fantasmas” (109), confiesa. Tiene que romper los vínculos con sus antiguos "compañeros de viaje, aprendices de brujo" (110) (remite al ritual sangriento del prostíbulo) y pareciera que Pain intenta asumir una culpa o responsabilidad, "estamos todos implicados en este infierno" (111), acusándolo a Rivette de pretender inocencia y estar al margen. Pero también reflexiona: "el viejo y yo éramos semejantes no sólo en nuestra disposición frente al laberinto sino también en nuestra común condición de espectadores" (111). Como Michel, hay una culpa que no se asume. Entonces, en este proceso de cuestiones para tramitar y que implica bucear por laberintos, entre fantasmas, se plantean tres ideas asociadas con la construcción de una memoria basada en acontecimientos traumáticos: el sacrificio del inocente, la salvación y la responsabilidad de todos, tres imágenes rodeadas del halo religioso del sacrificio, la culpa y la redención.

La condición de "espectador" es otra constante en la novela. Es la actitud pasiva de Pain y está relacionada con el motivo de la salvación. Pierre no puede salvar al esposo de madame Reynaud, ni tampoco a Vallejo, y aunque necesita salvarse a sí mismo no logra salir de su condición de espectador, de su imposibilidad para actuar. Por 
eso se reitera la imagen del sacrificio, como portador de la salvación, por momentos vinculado a la violencia (como la escena en el prostíbulo donde el entretenimiento consistía en ver a una prostituta 'ofrendada', rodeada de varias gallinas muertas y sangre); pero también tiene las marcas de un ritual que es necesario llevar a cabo (en Actualidad, hay una imagen de Michel frente a lo que parecía una "piedra de sacrificios aztecas" (131)); y con todas sus implicancias religiosas, la necesidad de salvación asoma acompañada de la idea de culpa o deuda. Es también en el cine donde Pierre siente una suerte de revelación: "Hay un inocente de por medio. Pensé: el sudamericano va a pagar por todos" (128). De modo que se reitera aquí el tópico de la "juventud sacrificada" que vimos en otros textos de Bolaño.

Pain se perturba y refuerza su condición de espectador cada vez que se encuentra con ese ser misterioso y a medida que avanza el relato la silueta tiene diversas identidades -Vallejo, Pierre Pain, su pasado. En una ocasión, espía desde lo alto de una ventana a los médicos de la clínica Arago y sospecha algo peligroso, un secreto, "busqué el interruptor, guiado por un impulso irracional, dar la luz, enseñarme. Confirmar sin asomo mi presencia, mi asistencia, un espectador humilde pero puntual" (149). Pero la luz no funciona y él continúa entonces en su posición distante, al margen de toda acción.

El tercer espacio significativo (la tercera experiencia con la memoria) es la clínica donde está internado Vallejo, percibido como un laberinto con luces que parpadean, al cual Pain entra no sólo para salvar al poeta sino para tramitar los conflictos con su pasado. “Buscaba a Vallejo o a otra persona?” (52), se pregunta por los pasillos circulares del hospital. Allí tiene otra experiencia similar a la que vivió en los otros lugares, en el cruce onírico con el pasado, durante la segunda vez que visita el hospital y le impiden ver a Vallejo. Pierre decide ingresar como un desertor, el "que hubiera podido ser de no mediar el gas" (142). Como quien ingresa a un campo enemigo, entre un espía y un prófugo, se "refugia" en un baño, luego decide buscar a Vallejo sabiendo que jamás encontraría su habitación, recorre las galerías interminables, y se pierde (144). Es allí donde repentinamente percibe una imagen del pasado "vi aquello al final del pasillo, como si todo el tiempo hubiera estado allí esperándome. Era apenas una silueta confusa (...) una pesadilla catapultada de golpe desde la infancia" (144). Las manos de Pain tiemblan, la silueta también; inmediatamente sale corriendo. Luego, nos dice que todo volvió a la normalidad, sus días continúan entre depresivos y desesperados, "aceptando la pena" (150). Así el recorrido por estos tres espacios 
cerrados manifiesta una tensión entre la búsqueda por tramitar una deuda con el pasado y la dificultad de articular una memoria que permita seguir adelante, "crecer".

\section{Hiperestesia y melancolía: una imagen de escritor revisitada}

Como ya adelantamos, además de las zonas por las que Pierre transita para tramitar su pasado el otro eje que desarrolla la novela es el de la figura del escritor que aparece encarnada tanto en Vallejo como en el mismo Pain.

Pierre Pain encarna al sujeto melancólico, atormentado por una sensibilidad exacerbada que no es ajena al contexto histórico que enmarca la novela. Es un digno pariente de algún personaje de Edgar Allan Poe o quizás su reescritura. En el intertexto explicitado en el epígrafe ("Revelación mesmérica") el narrador del relato de Poe, P., documenta una experiencia hipnótica con el Sr Vankirk, un enfermo terminal. Bolaño no sólo retoma a Poe al incluir en la novela el tema del mesmerismo sino que nombra a su narrador Pain y lo caracteriza con los rasgos que podrían describir a un personaje del escritor estadounidense: nervios crispados, alertas, el sensorium exaltado, deambulando entre lo real racional y lo irreal.

Esta hipersensibilidad resignifica una figura de artista característica de fines del siglo XIX. Bolaño recoloca al escritor decimonónico en una urbe sitiada, ante la inminencia de la guerra. La hiperestesia que caracteriza al artista ante los estímulos de una modernidad emergente se resemantiza frente a una coyuntura histórica que sólo respira violencia. Ya no está el flâneur que se pierde en la multitud en busca de vivencias novedosas. Pierre Pain recorre una ciudad vacía, entre el miedo y el peligro, habitada por fantasmas. Es la percepción del narrador la que impregna el relato de un suspense que crece gradualmente:

“(...) había algo que no calzaba, que intuía en los silencios de Madame Reynaud, en mi propio estado sensorial, alerta por razones que desconocía. Un malestar extraordinario subyacía detrás de las cosas más nimias. Creo que vislumbraba el peligro, pero ignoraba su naturaleza." (23)

A esta actitud de extrema sensibilidad Poe la denomina "percepción mesmérica", en ella se "percibe con agudeza y refinamiento, y por vías presuntamente desconocidas, cosas que están más allá del alcance de los órganos físicos” (Poe, 1844). Es la imagen 
de artista que todo lo aprecia, quien percibe más de lo visible. Pierre Pain distingue los olores de la noche "como si algo se estuviera moviendo por las calles" (51), su cotidianidad se ve interrumpida y busca comprender deambulando por calles vacías, “por momentos me ganaba la melancolía y a los pocos metros volvía a estar sereno, dueño de una tranquilidad atemporal, ajeno a cualquier sobresalto. Pero el temor, lo sabía, seguía allí, incorpóreo y tenaz" (77). Un sentimiento de peligro y desconcierto lo invaden constantemente y se intensifica con los datos externos, como esos espacios oscuros por los que Pain transita en Paris, lluviosa y desierta, en vísperas de la Segunda Guerra.

Esta hipersensiblidad pareciera ser una secuela de las experiencias traumáticas que el protagonista vivió durante la Gran Guerra. Pain recibe una pensión como inválido, "a los veintiún años me quemaron los dos pulmones en Verdún. Los médicos que me recogieron no supieron nunca cómo logré mantenerme con vida" (84), y su presente está signado por el horror de una guerra que no eligió. Es un pobre estudioso y practicante de las ciencias ocultas, quien rechaza a la sociedad que "tan tranquila lo puso en el trance de morir" (84). Pain encarna las ruinas que la guerra dejó, él mismo decide dedicarse a la ciencias ocultas para "empobrecerse sistemáticamente" (85).

La clínica donde agoniza Vallejo es como una "galería de arte" (34), "los blancos pasillos se sucedían como páginas de un libro escrito en lengua extranjera" (143), allí hay un enigma por descifrar, algo que tiene que ser dicho y es en la clínica donde Pain empieza a vislumbrarlo. El estado de Vallejo refracta en su interioridad y las pesadillas aumentan. Si bien parece siempre un espectador confuso, Pain también es un medium ("a mi mente llegaban escenas y voces (...) que nada tenían que ver con mis propios fantasmas, aunque de manera fortuita me hubiera convertido en el receptor", 52), un radioaficionado que captura otras voces, "un infierno de voces" (52). Padece una lucha agónica entre el silencio, el olvido, la posibilidad de hablar (el hipo) y el medio del arte para rearticular las voces del pasado, de los otros. Es por ello que en un momento Pain se ve como un radiotransmisor (sus sueños estaban compuestos por "voces, balbuceos, sonidos guturales", 52) que necesita buscar la frecuencia adecuada para comunicar, para significarse.

Pain ha tenido una experiencia traumática en la Gran Guerra, con sus colegas y no la ha tramitado, por lo cual se le convierte en pesadilla, lo tiene atrapado, intenta salir de ella, pero no puede traducirla en palabra. El silencio y la condición de espectador también se conectan, en un doble juego en el que Pain se siente víctima y culpable. 
Cuando los españoles le pagan para que no acepte el trabajo que le pide Madame Reynaud, Pierre no admite la posibilidad del soborno, porque no se reconoce con ningún tipo de culpa. Si bien todavía no había aceptado la propuesta, sabía que no podría rechazar a Madame Reynaud, pues estaba en deuda con ella al no haber podido salvar a su esposo. Los españoles le proponen el olvido "queremos que se olvide de todo" y ese olvido permite "la armonía" (42). Pain acepta ese olvido, aunque no llega a comprender mucho lo del soborno porque se siente inocente. De alguna manera, aceptar el dinero es una herramienta para destrabar el olvido y acceder al reconocimiento de que es partícipe o fue partícipe de algo (“cogí el dinero (...) sólo por no bloquear (...) el orificio", 49). A partir de este episodio, sus pesadillas van a ser más recurrentes. Los fantasmas del pasado van a regresar porque Pain dice que no puede hacer memoria (45).

En este contexto la figura agonizante de César Vallejo funciona como un espejo del mismo Pain. Vallejo y su hipo representan su situación, su incapacidad de hablar. La clínica y el almacén como espacios de la memoria devienen también espacios para la palabra. En varias ocasiones - diseminadas por toda la novela- también Pain aparece encerrado en el silencio. Sueña que alguien le "tapaba con suave y obstinada autoridad la boca” (27) “¿Cómo si pretendiera ahogarme? ¿Como si pretendiera obligarme a permanecer en silencio?” (28). Los pasajes oníricos insisten en la imposibilidad de la palabra. Pain intenta decir "que en alguna parte de la ciudad hay un hombre enfermo, pero me quedo con la boca abierta, incapaz de pronunciar un sonido cualquiera" (56), "Siento que me quedo mudo" (57). Cuando Pain ve por única vez a Vallejo, este "se revolvió y abrió los labios pero no llegó a articular palabra" (62), sólo su hipo rasga el silencio, débil y calmo. Pain realiza unos pases de energía y siente un atisbo de esperanza, ¿podrá sanar a Vallejo? Pero sólo el hipo desaparece y retumba ahora en su cabeza, Vallejo permanece inmóvil, hundido en su mudez.

Las "vidas" de Pierre Pain y Vallejo se cruzan no por azar sino -en "términos mesméricos"- por atracción magnética. Ambos comparten una experiencia común: el horror de la guerra, el resabio de la derrota. No son héroes condecorados, sólo son sobrevivientes olvidados. La figura ficcionalizada del poeta peruano incorpora lo que Idelber Avelar (2000) denomina una alegoría de la derrota. En Vallejo confluyen el ímpetu vanguardista, el espíritu militante y una extrema sensibilidad al sufrimiento que prevalece hasta el final de sus días. Para Bolaño, Vallejo no muere sino de tristeza, de soledad, con la palabra derrotada aunque insistente: es el hipo, espasmódico, molesto. La poesía de Vallejo enmarca esta necesidad/imposibilidad, basta recordar las líneas de 
“Intensidad y altura” (Poemas humanos): “Quiero escribir, pero me sale espuma,/quiero decir muchísimo y me atollo;/no hay cifra hablada que no sea suma,/no hay pirámide escrita, sin cogollo". El deseo y la impotencia, la dificultad y el esfuerzo por la palabra se intensifican en Bolaño: de la suavidad de la espuma al golpe incisivo del hipo. Las figuras espectrales de Pain y Vallejo reflejan los residuos de las utopías, las ruinas de la historia en un contrapunto que une Europa con América Latina.

Pierre Pain se debe un encuentro con el pasado, pero sus recuerdos del horror se cruzan con las señales de un presente poco tranquilizador, augurando peores acontecimientos. El enigma en torno al estado de Vallejo, junto con el acecho de los dos españoles cual heraldos negros, suman a la atmósfera de muerte en el marco de la Guerra Civil española un panorama venidero que tendrá su punto álgido con el nazismo que asolará a Europa. Llegan noticias sobre España de muertos a millares, de armas nuevas, y en un bar se comenta "los malditos alemanes ensayan su arsenal" (81); Pain recuerda a los médicos que lo atendieron y ve "detrás de sus rostros (...) jirones de un hospital de campaña y, más atrás aún, los pliegues de un cielo gris, el presagio de la tormenta" (84). Entonces todas las señales diseminadas en el texto de que algo siniestro va a ocurrir confluyen en el anuncio de la Segunda Guerra.

Como en otras obras de Bolaño, los relatos intercalados, los sueños o visiones de los personajes alumbran nuevos haces de significados. En una ocasión, Pain conoce en un extraño café a dos hermanos, artistas de miniaturas, que reconstruían catástrofes en grandes peceras minadas de cadáveres, “donde sólo ondeaban las banderas de la muerte" (71). Aquí, un cuarto espacio (que se suma a los tras anteriormente analizados -el cine, el almacén y la clínica) también funciona como significante revelador. Se trata de un lugar donde hay algo sumergido, como en la psiquis donde algo permance soterrado, latente y pugna por salir.

En una de las peceras, una locomotora estaba rodeada de "puntitos negros": “cabezas seccionadas" (71), no resulta casual que el tren encargado especialmente a Alemania se denomine Meersburgo Express. En esa ciudad alemana muere Franz Anton Mesmer, así el horror de la guerra y las ciencias ocultas se interrelacionan. El vínculo entre la ciencia y la violencia (recordemos que para Plemeur-Bodou el mesmerismo es útil en los interrogatorios de prisioneros y espías, y el conflicto de Actualidad gira en torno a esta cuestión) también se extiende a las relaciones entre el mal, la destrucción y el arte. De la conversación con estos hacedores de cementerios marinos surge, inesperada y sin una razón aparente, una palabra iluminadora: anamnesis, cuyas 
implicancias analizamos en Amuleto. Aquí podemos asociarla con el mesmerismo en tanto posibilidad de recordad, como una vía, un vehículo (como el tren que atraviesa ese espacio de horror sumergido) para la rememoración.

Insistir en imágenes de lo crepuscular, lo funeral, reincidir en visiones donde se respira una violencia latente es apelar a una memoria que, con palabras de Reyes Mate (2006), privilegie la mirada del sujeto que sufre. En línea benjaminiana, Mate afirma que "la memoria tiene que ver con el pasado ausente, el de los vencidos" (2006: 45); es decir, es la expresión de la derrota, de lo desechado por la historia. ${ }^{149}$ Así, Pierre Pain sabe que "las bombas, los gases, las enfermedades nos reventaban a nosotros, una tropa atemorizada y embrutecida compuesta de campesinos, obreros, pequeñoburgueses ilusos (84). El presente de Pain está impregnado de su pasado en las trincheras, tiene en su interior un nudo que no logra liberar. Y la misión de salvar a Vallejo se le manifiesta como una oportunidad casi redentora, descrita como un "movimiento" (se abre ante Pierre "Abril, un nuevo ciclo vital", 25) como si algo que antes estuviera trabado ahora pudiera comenzar a fluir.

César Vallejo se muere solitario, en una clínica laberíntica, atrapado entre el hipo y el silencio, sólo es un "minúsculo y quebradizo cuerpo humano". El poeta vanguardista, comprometido con la República, que estuvo en el frente de Madrid, se encuentra en un "estado anormal cuyas manifestaciones se parecen estrechamente a las de la muerte" (Poe). Vallejo no padece enfermedad alguna, sufre el ahogo de no poder pronunciar palabras, condición que Walter Benjamin describe en su tan citado ensayo sobre el narrador y la experiencia. El estado en que se encuentra Vallejo, semejante a esa condición mesmérica que Poe describía, entre la vida y la muerte, es análogo a la situación de Pierre Pain en conflicto entre los fantasmas del pasado y la parálisis del presente.

El mesmerismo como doctrina define al método terapéutico mediante el cual pueden curarse males gracias a una fuerza universal. Vinculado al magnetismo y la hipnosis identifica también al estado de un individuo bajo la influencia de la voluntad de otra persona. La condición mesmérica interrumpe las impresiones corporales, físicas,

\footnotetext{
${ }^{149}$ Señala que "un pasado será bien recordado si se concreta en un valor, en un patrimonio, que nos saca a nosotros, sus herederos, de penas. Ese es un pasado apreciado. Por eso será de mal gusto que alguien saque de la tumba a esos perdedores que no legaron nada porque a ellos mismos se les despojó de todo. (...) Todo el mundo prefiere recordar las divertidas canciones de Lili Marleen y olvidar las ruinas humeantes de Berlín" (48)
} 
externas y permite la búsqueda de otros medios de expresión, etéreos, internos. Un texto de William Q. Judge, co-fundador de la Sociedad Teosófica, explica:

Al separar a este ser del cuerpo externo al cual está atado, lo privaremos temporáneamente de la libertad, convirtiéndolo en el esclavo del operador. Sin embargo, los mesmerizadores, saben muy bien que el sujeto puede sustraerse, y a menudo se sustrae, al control, sorprendiéndolos y asustándolos. Todos los mejores escritores occidentales lo atestiguan.

En Monsieur Pain Bolaño relee el mesmerismo en la relación de Pain con su pasado. Sus recuerdos latentes controlan su presente y, por más que intente, no puede sustraerse a ellos. Aquí el mesmerismo revela la posibilidad de encontrarse con los fantasmas del pasado para construir una memoria, ya que el mesmerismo descubre un velo que desfigura y oculta (88). Para comprender esto es necesario acudir al intertexto de Edgar Allan Poe que resulta iluminador: por un instante, Pain se ve a sí mismo como un "Dr Templeton menos memorioso" (89). En el relato de Poe, "A Tale of the Ragged Mountains", el doctor Templeton es un practicante del mesmerismo que intenta salvar la vida de un paciente para redimir sus culpas por no haber evitado la muerte de un viejo amigo. Aquí, el presente convoca al pasado traumático a través de la figura de Bedloe (nuevo paciente de Templeton) que remite a Oldeb (su viejo compañero); Templeton no consigue salvar a ninguno. Su antiguo amigo Oldeb muere por una flecha envenenada, y Bedloe también muere envenado. La memoria de Oldeb lo persigue y el doctor no la puede tramitar. No hay posibilidad de salvación, no es posible saldar la vieja deuda. El mesmerismo entonces es una vía para acceder al pasado pero sin garantía de exonerar por completo sus fantasmas. Por ello el proceso melancólico refiere el duelo no tramitado, por eso una representación realista, con sus certezas, su confianza en la palabra, es insuficiente y Bolaño -Pain y Vallejo- se queda con el hipo, con la espuma. Es en esa zona intermedia donde no todo está resuelto que lidiar con los fantasmas del pasado solo es posible a través de un proceso de "elaboración" que articule el relato de lo que pugna por recordarse y lo convierta en palabra. Esto no es posible por el camino del testimonio que representa y explica en clave realista lo sucedido. Una estética melancólica, en cambio, muestra la voluntad de testimoniar junto con su misma imposibilidad, e incluye en el testimonio los nudos indescifrables de la memoria, los fantasmas que pugnan por adquirir representación aun cuando no es posible. Porque la 
escritura melancólica es la escritura del trauma que recuerda que los fantasmas acechan continuamente. La estética de la melancolía no ha logrado la elaboración completa ni la sutura del duelo.

Si bien Pain cree que podrá curar a Vallejo se enfrenta a obstáculos, fuerzas extrañas que lo impiden, y ya no podrá verlo más. El fracaso lo alcanza cuando Madame Reynaud, quien para mayor decepción de Pierre regresa con novio, le comunica la muerte del poeta peruano. Luego sabemos que el destino de Pain se resolvió entre espacios marginales, con números circenses y esotéricos entre prostitutas y traficantes. Ni siquiera funciona una última posibilidad de redimirse: intenta la lucha antifascista de la Resistencia pero todo queda en la nada y Pain termina sus días aplicado a la lectura de "manos manchadas de sangre, manos de verdugos y de putas siniestras, de vividores y de traficantes del mercado negro" (170).

Si como sostiene Roland Spiller (2009) el 11 de septiembre de 1973 "marcó un trauma dentro de la historia del fracaso de las utopías en Latinoamérica, en el siglo XX" (145) Monsieur Pain, gestada a principios de la década del ochenta, se presenta como una reflexión sobre la derrota en Chile, hilvanando los grandes acontecimientos históricos determinantes de la memoria colectiva del siglo XX: la Guerra Civil española y el nazismo; en un vaivén de acontecimientos signados por el horror anclado en la civilización occidental. Las políticas violentas, las dictaduras, el terrorismo de Estado y el fracaso de las utopías no conocen fronteras (Spiller, 146). Bolaño reflexiona sobre el mal y la violencia desde América Latina, a partir de las dictaduras de los setenta en el Cono Sur, hacia Occidente. Obras como Estrella distante, La literatura nazi en América Latina muestran un imaginario apocalíptico que recorre las dictaduras y posdictaduras latinoamericanas y que se termina generalizando al siglo XX occidental como en 2666.

\section{Melancolía, escritura y postdictadura: la palabra atragantada}

Monsieur Pain es también una novela de la posdictadura en tanto despliega lo que Idelber Avelar (2000) denomina su "terreno afectivo", como ya hemos mencionado: la experiencia de la derrota, el carácter interminable del duelo, la melancolía. Nombrar el presente como posdictadura implica recordar que es "producto de una catástrofe pasada", es marcar al tiempo presente como heredero de un conflicto no asimilable a denominaciones como "tiempos de 'democracia, (...) 'estabilidad', (...) 'gobernabilidad", expresiones que intentan ocultar esa "catástrofe". Para Avelar se 
impone una "mirada que aspira a ver en el presente lo que a ese presente excede -el suplemento que el presente ha optado por silenciar (...) su condición posdictatorial, su fantasmagórico duelo irresuelto" (37).

La reflexión sobre las características y tendencias del pensamiento en la posdictadura - la derrota, el duelo, la melancolía - forma parte de la agenda de debates abierta con la apertura democrática en el Cono Sur. Dentro de las posibilidades de sobreponerse a la pérdida del horizonte utópico a través de un pensamiento crítico, la posición melancólica se lee como ruina (Moreiras 1993), incapacidad (Galende 1998), paralización (Richard 2004); para la crítica cultural, la actitud melancólica de la posdictadura pierde politicidad. Sin embargo, Avelar advierte que el contexto posdictatorial de la derrota no puede ser sino melancólico; y el duelo, al no resolverse, demanda una memoria activa, en constante devenir presente, presencia. Entonces, hay la posibilidad de una melancolía crítica como antídoto contra cierto progresismo optimista (Avelar, 2000: 295), contra las fijaciones de sentido que derivan en 'memorias oficiales' cercanas a la amnesia, edificadas con el silencio tranquilizador de un pasado sellado.

En línea con la propuesta de Avelar, Christian Gundermann (2007) articula una nueva lectura del freudiano par duelo/melancolía con teorizaciones como las de Judith Butler, Paul Virilio, Abraham y M. Torok para rebatir las intervenciones críticas que han considerado por un lado, al duelo como instancia que permite tramitar la pérdida y superar el trauma y por el otro, la actitud melancólica de la posdictadura como síntoma de la inacción, el retraimiento o la ineficacia. Insistir en la melancolía como condición de posibilidad de una producción cultural crítica durante la posdictadura es negarse a pensar el pasado como instancia clausurada. Es decir, implica una resistencia que, lejos de estancarse en las utopías de los sesenta, se instala en el presente como "continuidad de la dictadura (...) en todos los niveles de la sociedad y sobre todo en el plano económico" (Gundermann, 165).

El potencial político y estético de la denominada "melancolía combativa" se delinea desde los aportes críticos de Judith Butler y su resignificación del mito de Antígona. La resistencia a las leyes del poder político amnésico que la figura de Antígona impone al enfrentar a Creonte da lugar a una "melancolía combativa" que se niega a aceptar el duelo, pasivo y privado (frente a la insistencia pública en su derecho a enterrar al hermano muerto). Gundermann relee la operación de Butler sobre la figura de Antígona desde la lucha de las Madres de Plaza de Mayo en Argentina y opone un 
trabajo melancólico frente al trabajo de duelo que para algunos críticos, como Avelar, se vuelve imperativo en la posdictadura. Señala que "la productividad del duelo no parece sino reestablecer el orden dado, parece relegar a la esfera privada los reclamos de la memoria" (54).

De manera que este potencial crítico de la melancolía complejiza los conceptos freudianos de duelo y melancolía que ya no son leídos como dos procesos separados o sucesivos. El punto de partida de Freud, como vimos con Nocturno de Chile, es la situación de la pérdida que provoca dos caminos de diversa índole. El trabajo de duelo permite reconocer la pérdida del objeto en un difícil proceso de abandono de las ligaduras que atan al yo con ese objeto perdido. Mientras que la melancolía supone un cuadro patológico en donde el yo no logra sustraerse al objeto de la pérdida y mantiene una herida abierta en la resistencia a olvidar. El acting out que Dominick LaCapra (2008) propone como instancia necesaria para la elaboración del trauma articula la melancolía con el duelo en tanto procesos complementarios. La repetición compulsiva, el retorno de lo reprimido (melancolía) se vincula dialécticamente con la elaboración del trauma (duelo) para, desde la distancia crítica respecto a la experiencia traumática, establecer un punto de partida para la acción responsable aún cuando el acting out no llegue a superarse (LaCapra 2008, 119).

Cabe destacar entonces que, como advierte José Amícola (2009), "la imposibilidad del duelo no lleva necesariamente a la melancolía", un binarismo excesivo reduciría la problemática de la memoria en lugar de desplegar diversos modos de abordarla. Para que exista una actitud melancólica hace falta un tono, un modo de ver que no excluye otras perspectivas, sino más bien constituye una elección.

Los personajes de Bolaño son melancólicos y sus narraciones tienen esa inflexión melancólica que lo colocan en una tradición latinoamericana desde la cual, trasvasando etiquetas y fronteras, da lugar al relato de las derrotas de los setenta. Desde América Latina hilvana, a su vez, otras derrotas históricas: está Pierre Pain en la Francia acechada por la ocupación nazi, está César Vallejo evocando una Sudamérica vencida. Roger Bartra bien entiende la melancolía como una "red mediadora" que hilvana el sufrimiento y la dislocación promoviendo una codificación, un entendimiento común anclado en la separación, el misterio y el dolor (Bartra 1998).

En los textos de Roberto Bolaño la melancolía es una nota radical de la escritura en tiempo presente. Luego de la caída de Allende ¿desde dónde se puede producir sino desde la melancolía? Siguiendo el esquema freudiano, la melancolía -frente al duelo- 
conlleva una experiencia traumática atrapada en el recuerdo. Esto provoca la inmovilidad, la imposibilidad de acción ante la pérdida. El recuerdo de esa pérdida convierte al que sufre en un espectador. Esta pasividad externa también es un motor de búsqueda de sentido. La melancolía dispara la necesidad de articular una memoria y el arte da cuenta de ello. En Monsieur Pain Bolaño encarna la proto figura de escritor melancólico de los noventa en la agonía de Vallejo quien muere de dolor (pain) junto a la España republicana, en una Europa donde se palpita el fascismo. Está también en Pierre Pain, en esa imposibilidad que lo caracteriza: con trabas en el recuerdo, en la acción. Es esta condición la que lo lleva a fracasar en el intento por pasar la experiencia a una lengua que articule claramente y persevera en la palabra melancólica, atragantada que demanda salir y solo deviene hipo, o espuma.

La conjunción entre melancolía y fracaso sólo parece funcionar en el plano de la praxis. Pain es un mero espectador, Vallejo muere de dolor ante la inminencia de una lucha perdida. Pero la fuerza de la palabra manifestada en el hipo insistente, en las voces que Pain canaliza da cuenta de una zona que pugna por emerger. Es la melancolía en su presencia más productiva y crítica a la vez, anunciando que ya no hay heroicidad en el arte; el artista militante devino artista melancólico porque se ha abierto una herida dolorosa que no será posible suturar.

Entonces para Bolaño la melancolía se vuelve un espacio adecuado para revisar los convulsionados episodios de la historia reciente, para evaluar las experiencias del terrorismo de estado, para recordar algunos episodios de las derrotas de las décadas pasadas en América Latina, e incluso para una autocrítica de la izquierda, de sus utopías y batallas. La melancolía también sirve a una estética, edifica una escritura en el cruce de lo real y el fantástico que revela una tensión entre la voluntad del testimonio y su propia incapacidad, la imposibilidad de un relato ordenado y racional ante los fantasmas que el mismo relato desata.

Si Monsieur Pain prefigura el espacio posdictatorial (Basile, 2000) asume que la posdictadura no es la época posterior a la derrota, porque "la derrota todavía circunscribe nuestro horizonte, no hay posterioridad respecto de ella" (Avelar, 2000: 29). Sin panegíricos ni mitologías, se trata de hacerse cargo de una generación entera de jóvenes de entre dieciséis y veintitantos años que no están, a diferencia de muchos de sus referentes y líderes que sí sobrevivieron, una generación que entregó su juventud a favor de una causa, como Bolaño relata: 
...luchamos a brazo partido, pero tuvimos jefes corruptos, líderes cobardes, un aparato de propaganda que era peor que una leprosería, luchamos por partidos que de haber vencido nos habrían enviado de inmediato a un campo de trabajos forzados, luchamos y pusimos toda nuestra generosidad en un ideal que hacía más de cincuenta años que estaba muerto (Bolaño, 2004: 37)

Las novelas de Bolaño se anclan en el escenario de la posdictadura chilena hurgando en el duelo y la melancolía, como vimos en Nocturno de Chile, pero también extienden ese duelo a la geografía más amplia de América Latina para perseguir allí las huellas de la derrota de los ideales sesentistas, como en Amuleto o Los detectives salvajes. Su proyecto creador se inscribe en los cambios de época (desde la década de los sesenta, fuertemente marcada por la revolución cubana hacia las experiencias de las dictaduras) y los nuevos derroteros de la literatura latinoamericana. Las huellas de la violencia exigen nuevos modos de abordar lo "real" porque la experiencia adquirió dimensiones inefables; una estética de la melancolía incorpora la derrota al aceptar que "Después del 11 de septiembre ya no nos estaría dada la posibilidad de creer en el proyecto de redención por las letras." (Avelar 2000: 25).

En Monsieur Pain se vislumbran los elementos que otras novelas y cuentos de Bolaño expandirán de una manera u otra: la melancolía, la violencia, misterios que -aún en clave de policial- no terminarán por develarse, el escritor pobre, los ideales que naufragan. Un universo que, rebasando operaciones de marketing editorial, nos reta a mirar nuestra historia reciente, sus vestigios desde un presente gris y melancólico, como la ciudad de Paris por la que deambula Pierre Pain.

Como texto de los comienzos Monsieur Pain establece una continuidad -sin estancarse en una cronología- con otras obras de Bolaño y anticipa un tono, un modo visceral de narrar lejos de una "evocación nostálgica de la contracultura rebelde de los años 60 y 70" (Castellanos Moya, 2009, 8) que atrapó a los lectores estadounidenses y formó parte de una estrategia editorial para renovar la visión de América Latina. No hay la nostalgia de un pasado con sueños de utopía, ni una épica de la resistencia heroica. Por el contrario, la melancolía devela los abismos de la utopía en un presente elegíaco desde el que la potente complejidad de la narrativa de Bolaño se erige, ajena al lagrimeo simplificador de ciertas visiones idílicas del pasado. En la "Nota preliminar" Bolaño cuenta que elige a Pierre Pain y a César Vallejo para empezar a ganarse la vida como escritor, con ambos obtiene los premios más importantes: los del comienzo. "Nunca 
como entonces me sentí más orgulloso y más desdichado de ser escritor", confiesa (12).

Como señala Said, los comienzos no son sólo una acción sino, además, una actitud. 


\section{EL POLICIAL: CRÍMENES DEL PASADO, HUELLAS DEL PRESENTE}

A los latinoamericanos el horror no nos impresiona tanto como a los demás “Jacobo Urenda, junio de 1996” (526) Roberto Bolaño, Los detectives salvajes

Aun reconociendo cierta línea de los estudios literarios que supone la clasificación de las obras en géneros como su desvalorización, en el ya clásico texto sobre la novela policial Tzvetan Todorov (1974) limita las posibilidades estéticas que las estructuras genéricas en rigor ofrecen pues cuanto más apegadas a ellas estén, mejor será la obra. Dentro de la esfera de la "literatura de masas", agrega Todorov, una gran obra es aquella que respeta las convenciones genéricas a las cuales se adscribe, mientras que en el "gran arte" es la transgresión a las reglas lo que determina la creación de una nueva especie mejorada. Esto último, para algunos se manifiesta en el neopolicial latinoamericano, otra subespecie del policial. Las dos especies en las que Todorov se concentra, la novela de enigma (o clásica) y la serie negra (o hard-boiled) constituyen dos momentos en la evolución del género que se distinguen en cuanto a su temática (el contenido, los personajes, etc.) pero conservan los rasgos formales que definen al género.

Ricardo Piglia lee la tipología propuesta por Todorov desde otras coordenadas. En "Lo negro del policial" (1979) Piglia establece el nacimiento de un nuevo género (la serie negra) tanto desde la serie literaria misma como a partir de coyunturas sociohistóricas particulares y resalta cómo el hard-boiled estadounidense nace con el objetivo de diferenciarse del tipo de relato establecido por Edgar Allan Poe en 1841. ${ }^{150}$ La combinación de los efectos devastadores de la Gran Depresión de 1929 con las políticas sociales de Franklin Roosvelt de la mano del auge de la cultura popular y con la vertiente realista y desencantada de la novela estadounidense de las primeras décadas del siglo XX configura las condiciones de posibilidad específicas para que la serie negra se constituya como una línea interna de la literatura norteamericana. La violencia

\footnotetext{
${ }^{150}$ A partir de "Los crímenes de la calle Morgue" Poe funda el género policial basado en ciertos elementos que lo definen (crimen/misterio, investigación/detective, pistas y deducciones/resolución), "El misterio de Marie Roget" (1842) y "La carta robada" (1849) son otros textos fundantes ineludibles. (Piglia, 1991)
} 
urbana y el crimen organizado, la clase alta y las instituciones corruptas son los materiales que perfilan el lado oscuro del sueño americano. Este costado crítico es el que se consolida en la vertiente policial latinoamericana en los años setenta. Ya Rodolfo Walsh a fines de los cincuenta inicia el viraje con Operación masacre, en el cambio del detective por el periodista y cuando la crítica se transforma en denuncia (Amar Sanchez 1992, 2000) para dar lugar así a otro género. Si como indica Ernst Mandel el policial negro estadounidense no llega a superar la ideología dominante sino que la crítica se queda en cuestiones menores (contra mafiosos de poca monta, policías corruptos y decadentes) y no apunta a cuestiones estructurales del poder político y económico, ${ }^{151}$ cierta reapropiación latinoamericana del hard-boiled constituirá un fuerte intento por contextualizar políticamente las obras y colocarse así como portavoces críticos, particularmente en el marco de las últimas dictaduras. El crimen está asociado con el Estado y se privilegia más el tono, la atmósfera y el poder del crimen que el enigma en sí.

Ya hemos visto cómo Roberto Bolaño considera los géneros literarios como matrices donde fundir diversos relatos. El policial no será la excepción y junto con el fantástico fraguará diversos hilos narrativos que lejos de configurarse en tramas cerradas abren la lectura hacia nuevas dimensiones. En novelas como La pista de hielo, Una novelita lumpen, Amberes, El Tercer Reich, entre otras, el policial se escurre en el escenario entre el crimen y el misterio para sondar la banalidad del mal, la pérdida de la pista, la búsqueda inútil del detective, del lector, en la trama de una violencia agazapada, pero siempre latente.

El recorrido de la narrativa policial en América Latina, y particularmente en el Cono Sur, ha sido ampliamente examinado por la crítica. Dentro del período que nos interesa, se han establecido diferentes etapas que responden a los usos del código del policial en diferentes grados. La primera etapa corresponde a los setenta y ochenta signados por el horror de las dictaduras y aquí la tradición norteamericana de la novela negra constituye un modelo adecuado para representar la violenta realidad. En Chile, los trabajos de Clemens Franken o Magda Sepúlveda se concentran en los modos en que el policial negro se vincula con los procesos de construcción de la memoria (Sepúlveda

\footnotetext{
151 "Para que las hazañas de Sam Spade (...) sean verosímiles deberán tratar en última instancia con criminales menores. El culpable podrá ser un magnate local, una estrelladle Hollywood o un rico aventurero, en vez de un patético mayordomo en una casa de campo británica o un joven frívolo (...); pero es a pesar de todo un criminal que da solo uno que otro golpe menor, no un líder poderosos de tipo mafioso, mucho menos una gran corporación" (2011: 91)
} 
1996: 118). Los lúcidos trabajos de Mirian Pino y Guillermo García Corrales indagan la articulación que la narrativa del Cono Sur hace visible entre literatura y dictadura, crimen y política (2002). Ramón Diaz Eterovic (2006) por su parte da cuenta de los modos de recuperación de la serie negra, ya sea asumiendo el género directamente o utilizando sus códigos y sus claves.

A partir de la década del noventa, un segundo período revitaliza la vertiente clásica, la novela de enigma, en tiempos de derrota en el marco de la posdictadura. Se vuelve a privilegiar la investigación pero en el ámbito privado, en crímenes pasionales por ejemplo. Como señala Miriam Pino "el relato neopolicíaco expone la falta de desmantelamiento del aparato represivo, y la continua intervención de la institución estatal en las vidas privadas" (2002: 53). Sin embargo, muchos relatos más que adherir al género, sólo utilizan alguno de sus códigos; observándose una desjerarquización de categorías que, sin anular la tradición genérica, impiden una lectura cristalizada. Así, las nociones de víctima, delito, detective o justicia se vuelven difusas en un clima de decepción y descontento. (Cánovas 1997; Clemens 2003).

Hacia finales de la década, una nueva línea asume rasgos distintivos que, en el horizonte posmoderno, intensifican el carácter metaficcional (Pellicer 2007: 20) desde el borgeano mandato del policial como "género intelectual" (Borges 1979). En esta nueva vertiente el enigma y su pesquisa incluyen al narrador y al lector de modo que "la propia construcción del texto se convierte en una búsqueda de los rastros del artificio del lenguaje" (Mauro Castellarin 2007: 15). En este sentido, Rosa Pellicer articula el policial con la metaficción y señala la "proliferación de escritores detectives (...) y de críticos detectives lo que favorece tanto al carácter autoconsciente de la narración como la creación de argumentos relacionados con la literatura, a la vez que acentúa el carácter ficticio de la narración" (2007: 20).

De una manera u otra el consenso radica en que las principales transformaciones de la narrativa policial en América Latina responden a la coyuntura histórico-política de la región. Así el denominado "neopolicial”, tal como el mexicano Paco Ignacio Taibo II acuñó para resaltar la diferencia latinoamericana, se tornó un vehículo adecuado para cifrar ya sea los acontecimientos de la historia reciente, desde el conocimiento de los crímenes hasta la búsqueda de justicia, como para erigirse contra lo establecido. El escritor mexicano define el neopolicial de la siguiente manera: "es la gran novela social del fin del milenio. Este formidable vehículo narrativo nos ha permitido poner en crisis las apariencias de las sociedades en que vivimos. Es ameno, tiene gancho y por su 
intermedio entramos de lleno en la violencia interna de un Estado promotor de la ilegalidad y el crimen" (Scantlebory 2000: 2)

Si el auge del policial en Chile en las narrativas de Ramón Díaz Eterovic, Roberto Ampuero, Gonzalo Contreras (como Ricardo Piglia u Osvaldo Soriano en Argentina) conduce a revisar los desplazamientos frente a los clásicos modelos del género (sistematizados por Todorov), una lectura de la obra de Roberto Bolaño a la luz de estas cuestiones permite incorporar todas las bifurcaciones del género mencionadas anteriormente. Las operaciones que Bolaño realiza con el policial permiten recuperar los perfiles de las tres etapas antes mencionadas en un cruce que articula el horror de la serie negra, el enigma del policial clásico y la autoconciencia de la escritura del "policial intelectual" sin llegar a ubicarse en el casillero del neopolicial. Bolaño opera en el interior de los diversos modos del policial diluyendo sus fronteras, combinando sus procedimientos. El policial asoma en el relato e impregna atmósferas, personajes y sobre todo al lector, sin llegar a cristalizarse en un solo tipo. Como señala Rodrigo Fresán (2003), se vuelve "un género líquido que no está obligado a resolver el misterio sino a, simplemente, enunciarlo".

De los varios trabajos que han abordado la cuestión del policial en Bolaño destacamos el artículo de Ezequiel De Rosso quien esquematiza en tres ejes las principales características del policial en tanto género. En primer lugar, el rasgo distintivo está dado por la estructura del relato organizado en pos de la revelación del enigma, luego una serie de rasgos temáticos incluyen personajes y ambientes típicos y por último, un tercer eje articula texto y lector. De Rosso se focaliza en este último elemento para explorar los diversos desplazamientos que Roberto Bolaño realiza, a partir de los usos del policial convertido en "matriz genérica" (De Rosso 2002: 135). Justamente es esta matriz la que se mantiene siempre constante y dispara toda la potencialidad del policial sin llegar nunca a estancarse. En La pista de hielo la contrariedad con el género radica, por ejemplo, en la nula importancia que la víctima, e incluso el asesino, adquiere en el relato; en Estrella distante, señala De Rosso, asistimos a la transformación del crimen político en algo privado (2002: 136). Pero el rasgo más interesante que resalta De Rosso es la transformación del enigma en secreto: es esto lo que perturba al lector, y es el motor del relato. De Rosso insiste en la importancia del lector, quien reconoce las premisas del policial en el relato -por lo tanto espera, sospecha y conjetura. Este modelo de lector que propondría Bolaño recuerda a Borges, quien alegaba que "los géneros literarios dependen, quizá, menos de los textos que del 
modo en que estos son leídos" (Borges 2007: 229). En la narrativa de Bolaño, señala De Rosso, hay "la decepción sistemática de las expectativas del lector de género" (2002: $135)$.

En La pista de hielo es precisamente el crimen y su resolución lo más decepcionante. Si el caudal narrativo se dirige a develar dos enigmas que involucran un proyecto misterioso y al menos un cadáver, a medida que transcurren las historias (la historia desde tres voces) su potencia va disminuyendo casi hasta rozar el sinsentido (del asesinato) y lo trillado (el proyecto Benvingut). La novela está narrada entonces a través de tres voces (con el guiño adicional de pertenecer a personajes cuya nacionalidad alude a tres geografías bolañianas: Chile, México y Barcelona; además de otros motivos autoficticios). En cada presentación se inyecta una dosis de misterios asociados a un crimen. Remo Morán, inmigrante chileno devenido comerciante en ascenso, relata su primer encuentro con Gaspar Heredia en México y exclama evocando los días jóvenes: “¡De la calle Bucarelli al asesinato!” (9). Gaspar, poeta mexicano, necesita con urgencia un trabajo por lo que Remo le ofrece el puesto de vigilante nocturno en el camping Stella Maris. Por último, Enric Rosquelles es un psicólogo y abogado barcelonés, funcionario del pueblo Z, cuyo perfil bien describe Remo: "gordito asqueroso, lleno de miedos y manías" (42), meticuloso y obsesivo, incluso en los detalles de su relato confesional. Si bien su discurso ya lo apunta como culpable de algo no es fácil deducir el hecho salvo que involucra a su amor, la patinadora profesional Nuria Martí y a un proyecto en el Palacio Benvingut, en ruinas.

De manera que a partir de estas tres voces la novela instala un eje descentrado que va pincelando un cuadro enigmático, de contornos difusos, que si bien va delineando unas pistas impide trazar un recorrido certero que concluya con la resolución a la que todo policial aspira. Con el palacio se abre el primer umbral hacia el enigma de algún crimen que involucra a Enric y por el cual se estaría justificando con su relato ("aquello por lo que tendré que pagar", 21). Cuando Nuria casi adquiere los rasgos de una obsesión para Enric, el lector engañosamente es guiado a conectar ciertos indicios con un futuro fatal para Nuria, como una posible víctima. En cierta medida, la patinadora es víctima (y cómplice) de los excesos de Enric pero las imágenes que la rodean anuncian algo más grave que una malversación de fondos del ayuntamiento. Poco a poco se acomodan las piezas que develan el proyecto Benvingut como un capricho de Eric para consentir a Nuria quien carece de una pista de hielo para entrenar. Además, Remo también suma sospechas con pistas que apuntan a un crimen en el 
palacio y al no involucrar a otras posibles actores, Nuria y Enric se presentan como principales sospechosos (de ser víctima o victimario) (31). Este espacio (la pista de patinaje sobre hielo) se manifiesta entonces como motivo central en la arquitectura de un relato policial que carece -como Nuria- de pistas claras y útiles para armar la historia del crimen. Los indicios se deslizan, como por el hielo, y se escapan hasta tal punto que la trama, ya fracturada por las tres voces narrativas, deviene un vagabundeo inestable que inyecta aquello que corroe los marcos seguros del género.

Las primeras intervenciones de Gaspar y Remo relatan sus esfuerzos laborales y su día a día como inmigrantes, junto con algunos recuerdos de México durante su juventud cuando formaban parte del grupo de "los poetas de hierro" con amigos (31). Una segunda puerta a otro posible crimen, o el mismo, se abre en el camping a través de la galería de personajes extraños, y marginales, que en él se hospedan. La estructura de la novela permite ir espaciando con cuentagotas las revelaciones de los enigmas planteados al mismo tiempo que se van diluyendo. Una vez presentada la lógica del policial, la trama teje y desteje sus supuestos. Cuando están todos los elementos expuestos no existe un aceleración narrativa que conduzca al desenlace resolutivo sino que las historias siguen su curso sin detenerse en lo que parecía ser lo fundamental. Este proceso de desintegración del policial genera un quiebre en el orden de la palabra al no poder presentar a través de la narración el verdadero y oculto nudo de la cuestión. La atmósfera que se gesta apunta a un centro desquiciado, a un fondo medular al que no se accede pero que corroe el sistema mismo del policial y sus efectos somatizan el relato a través del constante anuncio de algo que se resiste a mostrarse. Es el enigma que no sale a la luz, es el cadáver que pierde importancia de manera tal que los elementos del género están esparcidos y desestabilizados por una fuerza desquiciada a tal punto que no es posible armar un sistema lógico que conduzca al final tranquilizador y reparador de las reglas del juego detectivesco.

El encuentro del cadáver, tan anunciado, decepciona primero porque no pertenece a Nuria (como podía inferirse) sino a Carmen, una vagabunda, ex artista que se alojaba en el Stella Maris junto con la enferma Caridad, joven que deslumbra a Gaspar. Las treinta y cuatro puñaladas a Carmen bien podrían haber provenido de Caridad, quien gusta de portar arma blanca y con quien convivía en las habitaciones abandonadas del Benvingut. Sin embargo, el culpable es otro personaje menor, el Recluta, mendigo hospedado en el Stella Maris, cuyo móvil ni siquiera se insinúa. En el palacio confluyen los personajes y como escenario del crimen adquiere relevancia, más 
por el delito de Rosquelles que por el asesinato pues ni el culpable, ni su móvil cierran la historia. Sólo conocemos las consecuencias del proyecto secreto de Rosquelles (un caso más de corrupción) y el vacío que rodea a los personajes ahora se cierne sobre la narración misma. Al tratar la cuestión del enigma en el relato policial en sus nuevas variaciones, Ricardo Piglia (1991) se pregunta por la posibilidad de ligarlo a los procedimientos narrativos. Así, el secreto se concreta en los vacíos de la narración, lo no dicho ocupa un lugar en ella. Esta espacialización del enigma puede leerse en las narraciones contaminadas por el policial que Piglia llama ficciones paranoicas. Las mismas involucran una forma y un contenido cuyos elementos son la amenaza (el peligro, la conspiración) y el delirio interpretativo (lo que lleva a buscar causas, mensajes cifrados - como Enrique Martín, en el cuento homónimo de Llamadas telefónicas). En los textos de Bolaño el enigma, el secreto y el vacío son figuras constantes que traslucen el acecho de la amenaza y, con la falta de la figura del detective, el desamparo del lector (y también del narrador) deviene un compulsivo intento de interpretación (a veces, sobreinterpretación en términos de Umberto Eco) que apunta a desentrañar el enigma y la amenaza que oculta. Como hemos indicado, hay una difusión de pistas que sin embargo van quedando en el camino, ${ }^{152}$ junto con las marcas del género matriz que estallan en partículas que despistan e incentivan una paranoia desinflada en la que el lector "intenta" la sospecha para armar hipótesis sobre el crimen, buscar culpables, etc. que pronto quedarán sin efecto.

La imagen central que instala el espacio de la "pista de hielo" evoca la figura del "iceberg" que oculta bajo la superficie el sostén más contundente de lo visible. Sin embargo, nada hay que emerja y otorgue completamente sentido a lo que apenas se muestra. Porque los indicios del relato no se constituyen como vías de acceso a lo oculto y lo soterrado sino por el contrario se quedan en la superficie, se deslizan sobre la pista de hielo. Además, el palacio Benvingut está en ruinas por lo tanto la destrucción externa también funciona como una carcasa que oculta la pista de hielo. Bolaño presenta un "policial frío" cuyo núcleo se descompone a causa de una potencia oculta que el relato somatiza en la desintegración de la estructura rígida del género (en ruinas). No es difícil conectar esta imagen con la idea de trauma en donde sobreviene el poder violento de lo acontecido y desestabiliza, perturba, avanza y retrocede. La figura del trauma permite pensar el policial como un modo de acercarse al mal no solamente como

\footnotetext{
${ }^{152}$ Mirian Pino (2006) bien resume el efecto de que "todo se disuelve en el hielo de la pista" aunque no llegue a desentrañar las causas de esa disolución.
} 
manifestación de las injusticias perpetradas por el Estado o las instituciones corruptas sino también como una fuerza hostil que pugna por articularse, autoproliferándose. En este sentido, el trauma del relato manifiesta la imposibilidad de la palabra, el desorden de la narratividad que es uno de los ejes fundamentales de la novela Amberes.

Amberes $^{153}$ es un extraño caso de desorden narrativo que se constituye, según Rodrigo Fresán (2002), en un luminoso flashback al Big Bang inicial de Bolaño. En la primera edición de 2002, el prólogo del autor narra el alocado contexto de enunciación de este texto que "tendía a multiplicarse y a reproducirse como una enfermedad" (10). Bajo la impronta de la rabia y la violencia (10), sin interés por el lector, con desprecio por la literatura oficial y la marginal (10) nacen estas "páginas sueltas" (9) en 1979 o 1980 en la encrucijada entre el policial, la poesía y la autoficción.

Hay dos recorridos - dos "carreteras gemelas" (16)- que retacean todo intento por tramar una historia, o aún mejor, van armándola a partir de las imágenes y las palabras que sofocan la acción. Una proyecta una película, la otra ensaya una escritura agónica, en la lucha entre lo real y la palabra. El comienzo es cinematográfico desde el epígrafe, en el que el productor David Selznick (Lo que el viento se llevó) resalta el engaño de las apariencias, de las fachadas. De aquí en adelante, nada será lo que parece. Un hombre mira la costa marina y escribe. Un hombre viaja en tren, fuma y escribe a partir de una traducción lírica de la realidad que lo rodea, de la sinestesia (un grito es un sonido breve que parece "un color tragado por una fisura", 19) pasa a la materialidad pura de las palabras que crean lo real y a la vez lo limitan: "la palabra 'rostro' crea sus propios ojos azules. Alguien grita. Observa sus pies fijos en el suelo. La palabra 'zapatos' jamás levitará" (19). El tren atraviesa el bosque y se menciona a otro personaje: el jorobadito. Sin aviso, hay un cambio de escena y aparece el jorobadito comiendo en el bosque. En el mismo párrafo la simultaneidad de planos es uno de los rasgos que complejizan una lectura que busque ordenar una historia; al mismo tiempo la repetición de motivos, personajes o lugares permiten acercarse a ciertos hilos conductores. Aquí, se fusionan los dos recorridos, se cruzan el jorobadito (en el bosque) y el escritor (desde el tren). Otra escena involucra un camping y el asesinato de seis chicos, hay interrogatorios y sospechosos que solo se atisban en frases sueltas entrecomilladas (tal vez, la transcripción del texto del escritor que tampoco es uno sólo: hay un sudamericano que

\footnotetext{
${ }^{153}$ Myrna Solotorevsky (2011) ha indicado los elementos que Amberes y La pista de hielo comparten.
} 
escribe y hay un escritor inglés). La profusión y superposición de imágenes con que comienza la "novela" desquicia el orden base del género narrativo (la sucesión lógica de acciones llevadas a cabo por personajes, etc) y además intenta un encuadre para colocarse dentro de la matriz del policial que implosiona al instante. La estructura del texto también apunta en esta dirección: son cincuenta y cinco fragmentos a modo de “capítulos", numerados y con sus títulos que no llegan a cumplir una clara función como paratextos.

Una punta del ovillo es la muerte de la poeta belga Sophie Podolski, veintisiete años "como yo" (25) dice el narrador, y unas páginas antes alguien se presenta: "Me llamo Roberto Bolaño" (22) de modo que es posible asociar una de las voces narrativas con la autoficción de Bolaño (en 1979 tenía veintisiete) un escritor, poeta sudamericano, que en una habitación del Distrito $\mathrm{V}$ fuma y escribe $-\mathrm{o}$ piensa que escribe. Entre las descripciones grises de Barcelona hay más cadáveres: alguien acribillado, una joven poeta de dieciocho años en la escena del crimen, policías y camilleros, una manifestación de fondo (que hace sistema con frases sueltas anteriores: "Metralletas, pistolas, granadas decomisadas" (25), "Escapé de la tortura" (28)). Los personajes que se mencionan pueden prestarse a generar una trama, a partir de la isotopía que remite al policial, pero son sus discursos los que no encajan y se vuelven indescifrables (“Enumerar es alabar, dijo la muchacha” (29) y más adelante la primera persona explicita la confusión: "No puedo hilar lo que digo. No puedo expresarme con coherencia ni escribir lo que pienso" (29). Esta imposibilidad de la palabra es otro eje del texto en tanto emerge tematizada en diferentes fragmentos así como en la textualidad misma de Amberes. Mujeres sin bocas aparecen en sueños y visiones, hay un escritor que intenta escribir (para subsistir) y no le sale nada, entonces sólo escribe breves textos policiales (33). Esto se une con el apartado siguiente ("12. Las instrucciones") donde la primera persona narrativa ya no es un escritor sino un policía en busca de una persona. Y también es el muerto del camping. ${ }^{154}$ Es como si el autor ensayara todos las formas de escritura que surgen sin poder ordenar ninguna, "el silencio ronda en los patios sin dejar papeles escritos, aquello que después llamaremos obra" (97). El tópico de la palabra imposible se coloca en primer plano como resultado de un núcleo velado que corroe la lengua, corta la coherencia y desguaza la narratividad genérica.

\footnotetext{
154 "Un campista me descubrió (...) me rodean hombres de uniformes azules y blancos. Guardias civiles, fotógrafos de periódicos sensacionalistas o tal vez sólo turistas aficionados a fotografiar cadáveres” (91)
} 
Cuando aparecen en escena los policías se explicita la investigación de un crimen, las pistas están en las fotos tomadas por una Zenith, el jorobadito es un sospechoso y es mexicano. Las escenas cinematográficas transcurren en un DF que ya no existe (46). Hay espacios que vuelven a aparecer y atisban una continuidad narrativa: el bosque (donde el jorobadito proyecta una película), bares costeros (donde se escuchan historias sórdidas de policías que persiguen emigrantes), habitaciones (donde prostitutas trabajan), el picadero de caballos (la joven pelirroja presencia una violación). Estos elementos (ciertos personajes y los espacios) conforman la sinopsis de la historia que nunca se cuenta (51) sino que se muestra fragmentada, con imágenes visuales que predominan (los colores, las luces) en el montaje cinematográfico donde distintas tomas (primeros planos, en picada, fundido a negro) impiden recrear una secuencia lógica. Asimismo un escritor (parece que es inglés) confiesa que sólo salen frases sueltas porque la realidad parece "un enjambre de frases sueltas" (69). Esta autorreferencialidad conforma una estética anárquica, como describe el prólogo y reafirma el mismo texto, ("No hay reglas", 103), que toma la forma de un cuaderno de notas, embriones literarios de una escritura que pugna por manifestarse y consolidarse en un proyecto creador impresionante. Como Monsieur Pain y La pista de hielo, Amberes es una escritura de los comienzos que se instala en la intersección entre la violencia y la poesía ${ }^{155}$ desde el secreto oscuro que acompaña a ambos. Rodrigo Fresán define a Amberes como "un policial atípico donde no se buscan explicaciones sino que se encuentran más enigmas", bien podría estar definiendo también el libro de arena de Bolaño que explora las derivas de personajes en una búsqueda constante de pistas, fuera de marco y marcados por la experiencia - a veces directa, otras oblicua- de la violencia y la lógica de un mal que amenaza e impide consolidar sistemas de comprensión que lo abarquen y lo atomicen porque subyace a todo. Es el relato del trauma y el trauma del relato lo que impulsa los usos del policial en las novelas que comentamos en este capítulo.

En Una novelita lumpen ${ }^{156}$ la intriga invierte la lógica de la acción del policial pues se presentan los delincuentes y lo que no se sabe es si el crimen se llevará a cabo. Sin embargo, nada sucede debido a que el hecho violento ya aconteció. Ya en lo que

\footnotetext{
${ }^{155}$ Amberes aparece en la antología de poemas arreglada por el mismo autor en 1993, La universidad desconocida, y publicada en 2007.

${ }^{156}$ Novela por encargo de la editorial Mondadori, en el marco del proyecto Hora 0 en el que siete escritores retrataba diferentes grandes ciudades para recibir el nuevo milenio. Otras: Mantra (Rodrigo Fresán- Ciudad de México), El tren a Travancore. Cartas indias (Rodrigo Rey Rosa- Madrás).
} 
parece ser un esbozo liminar de la novela, en "Músculos" (el texto incluido en el póstumo El secreto del mal), el trauma articula las vidas de dos hermanos que buscan encauzar su existencia. El hermano de Marta, la narradora, es tan fanático de los filósofos presocráticos como del gimnasio y atraviesa sus primeras experiencias homosexuales con dos amigos sudamericanos quienes, además, lo inician en el delito. Estas líneas argumentales mutan y se expanden en Una novelita lumpen donde Marta es Bianca (continúa el rol de narradora), el par de sudamericanos pasan a ser un boloñés y un libio o marroquí, y quien se inicia en el sexo es Bianca. Su relato es una retrospectiva hacia la época en que era una delincuente (ahora está casada y tiene un hijo) e inicia con una justificación que es además el punto de partida de una vida nueva: la muerte de sus padres en un accidente automovilístico. El cambio fundamental no será la forma en que los huérfanos decidan sobrevivir (a través del robo) sino el modo en que Bianca percibe la realidad: "De pronto la noche dejó de existir y todo fue un continuo de sol y luz" (15). Incapaz de distinguir el día de la noche, Bianca vive un continuum de luz incesante que le permite ver en las oscuridad (de hecho, sus días carecen de oscuridad). Esta manifestación del trauma por la pérdida de sus padres no afecta su ánimo, al contrario sus sensaciones se intensifican y quiere ser otra, deambular por una Roma desconocida, "olvidar las pocas cosas que sabía" (27). Sin embargo, poco a poco tiene visiones que la alertan, son los presentimientos de una catástrofe que ennegrece el cielo (44). El relato entonces se articula a partir de la negación del acontecimiento traumático que constantemente retorna y ocupa una zona perturbadora en la cotidianeidad de Bianca y su hermano.

El aprendizaje sexual se inicia con películas pornográficas y se pone en práctica con los amigos inmigrantes del hermano hasta que Bianca siente que necesita algo más. La sensación de vacío y la inminencia de una desgracia nunca abandonan a Bianca quien se sabe dentro de un proceso de precarización que terminará en la delincuencia. El segundo cambio en su vida está marcado por la ausencia del llanto (antes Bianca lloraba diariamente al salir de la peluquería donde trabaja) que viene de la mano del plan criminal que llevarán a cabo. Se trata de un robo a un millonario recluido en su mansión, Giovanni Dellacroce, alias Maciste, un ex actor de peplum ${ }^{157}$ quien además de vivir solo, es ciego. No es casual el nombre que evoca la noche oscura de la doctrina

\footnotetext{
${ }^{157}$ El género popular de origen italiano péplum refiere películas de aventuras enmarcadas en la épica grecorromana cuyo héroe, Maciste, solitario y musculoso (evoca la figura de Hércules), lucha contra el mal. Uno de los actores íconos del género fue Steve Reeves, también Mr Universo.
} 
mística porque cuando Bianca conoce a Maciste por primera vez en mucho tiempo se ve inmersa en la oscuridad total (88). Será la encargada de buscar la caja fuerte mientras comparte el tiempo con el ex Míster Universo en calidad de dama de compañía/prostituta. El delito fracasa porque no hay dinero escondido en la casa de Maciste, a quien Bianca cuida hasta que decide otra vez cambiar de rumbo. "Voy a empezar un vida nueva" (148) le dice en la despedida. Ella y su hermano deciden no ver nunca más al libio y al boloñés y por primera vez se asumen solitarios, oscuros y frágiles. Como si comenzaran a transitar el proceso del duelo que fue articulándose a partir del pasaje de la luz a la oscuridad, como si esa violencia soterrada emergiera para cubrirlo todo.

A través del delito (que no se concreta) se realiza el reconocimiento de una realidad reducida a su mínima expresión. La superficialidad del gimnasio, el cine porno y sentimental, los programas de televisión son algunos de los asideros de los que Bianca y su hermano echan mano para no hundirse en el vacío de sus vidas a la deriva. Como en Maciste, la degradación es existencial y cultural. Así lo demuestra el test que Bianca responde en una revista de estereotipos femeninos: ella se sabe afuera, todas las opciones que elige remiten a la oscuridad, a la marginalidad, a la vida lumpen (le gustaría ser: rata, búho, fosa marina, un taxi en Los Ángeles con los asientos manchados de semen y sangre lumpen; a quién matarías: a cualquiera que pase por la ventana, 64) y su voz (la que relata desde el lugar de mujer casada, con un hijo) no puede transformarse en otra cosa más que en una novelita. Como afirma Artaud en el epígrafe: "Toda escritura es una marranada. Las personas que salen de la nada intentando precisar cualquier cosa que pasa por su cabeza, son unos cerdos". En Una novelita lumpen la estela narrativa del trauma se percibe de un modo más lineal: Bianca niega el accidente de los padres desde la luminosidad que se impone como un modo extraño de enterrar el peligro, que regresa, no obstante, y se vuelve presencia (presente) con el ciego Maciste, la oscuridad plena para iluminar una existencia vacía y superficial.

Con Estrella distante vimos cómo en los usos del policial que Bolaño practica asoma la cuestión de la justicia propia del género aunque aparezca de un modo trastocado, nebuloso en tanto se libra por supuesto dentro del nivel de la ficción. En la novela El Tercer Reich el eje de la justicia es recuperado y se filtra en un plano lúdico que adquiere ecos siniestros. 
El Tercer Reich (escrita hacia finales de la década del 80 y publicada en 2010), una de las menos transitada por la crítica, permite indagar en los usos del policial y los aportes que Bolaño expone desde una época posdictatorial signada por la derrota, la melancolía y el recuerdo material y punzante de la violencia. Esta novela constituye un territorio ideal para explorar las marcas del género que Bolaño retacea en un juego que imprime un código al mismo tiempo que lo diluye, en un relato anclado entre los vaivenes de lo cotidiano y el horror.

El lector de El Tercer Reich, siguiendo a Borges y a De Rosso, reconoce diversos hilos que traman el relato en clave policial, y dos de ellos son nodales: el crimen y la necesidad de justicia, ambos desde la singular mirada bolañana. La primera clave que se arroja al lector está, como es costumbre en la narrativa de Bolaño, en el intertexto, en las alusiones literarias nunca inocentes. Así, el epígrafe de Friedrich Dürrenmatt ${ }^{158}$ que inicia la novela coloca al relato entre las zonas preferidas de nuestro escritor: los nudos penosos de la historia -que abarcan tanto la desolación que dejaron las dictaduras latinoamericanas como la violencia en otros marcos totalitarios, como el nazismo- y la necesidad de articular memoria y justicia, que en El Tercer Reich se instala en el terreno de lo lúdico y en un plano simbólico que es la literatura -la escritura- misma. El pasaje de El desperfecto de Dürrenmatt apunta explícitamente a la condena de un general alemán, sin embargo esta instancia de justicia permanece ajena a cualquier sistema jurídico puesto que, sabemos, forma parte del juego que unos jubilados alemanes practican de sobremesa. Es una justicia que se libra en el plano ficticio, ${ }^{159}$ y que condensa el principal conflicto de la novela: la "lucha mental" entre Udo y el Quemado, tal como el escritor argentino Fabián Casas (2010) caracterizó a esta extraña y tensa relación.

Nuestro narrador protagonista es Udo Berger, joven alemán experto en wargames (juegos de tablero que recrean grandes batallas), quien se encuentra de vacaciones en la costa catalana junto a su novia Ingeborg mientras trabaja en la táctica del Tercer Reich, el nuevo juego del cual pretende consagrarse como experto. El relato es el resultado de las entradas diarias de Udo, decidido a escribir su diario íntimo durante las vacaciones para ejercitar su escritura, lo que redundará en mejorar su estilo,

\footnotetext{
158 "A veces jugamos con vendedores ambultantes, otras con veraneantes, y hace dos meses hasta pudimos condenar a un general alemán a veinte años de reclusión. Llegó de paseo con su esposa, y sólo mi arte lo salvó de la horca.", Friedrich Dürrenmatt, El desperfecto, Buenos Aires, Compañía General Fabril Editora, 1960.

${ }^{159}$ Aunque en la obra de Dürrenmatt tenga consecuencias bien concretas como el suicidio de Trams (como resultado del juego).
} 
su sensibilidad, su carácter (19). A medida que se desarrolla la narración vemos cómo el ejercicio de la prosa para sus futuros artículos sobre juegos pasa a segundo plano pues la "voluntad de escribir" (12) se convierte en un modo de ordenar y comprender los hechos que suceden.

En un principio sus vacaciones en el hotel Del Mar transcurren con normalidad, hasta que aparecen dos nuevos personajes, Charly y Hanna, y Udo comienza a dar cuenta de un desequilibrio, una nueva atmósfera empaña el relato, "fatalmente no tardó en sentarse en nuestra mesa una pareja de alemanes" (26). Esto se intensifica con la pronta aparición de otro personaje, el Quemado, encargado del alquiler de patines en la playa. Este ingresa al relato signado por lo extraño, anormal, en principio por la disposición de los patines que tanto sorprende a Udo, luego a causa de su aspecto físico, monstruoso, con su cuerpo lleno de quemaduras "como carne a la plancha o placas de avión siniestrado" (34). El mismo día que conocen al Quemado aparece el sentimiento que se tornará una constante: el miedo, sin razón u origen. La relación entre Udo e Ingerborg ya no será la misma, conocemos el rechazo de su novia a los juegos bélicos y se instala la sensación de ruptura, "con verdadero horror me doy cuenta de que algo comienza a interponerse entre nosotros" (46).

Empiezan también las pesadillas de Udo con Florian Linden, protagonista de las novelas de enigma que lee Ingeborg, y es precisamente Linden -cuyas historias desprecia por disparatadas- quien proporciona ciertos motivos propios del policial, que desconciertan a Udo pero que ayudan al lector a activar el código y así, se espera la concreción de un crimen, la develación de algo oculto, y todo se torna sospechoso (es casi una saturación de los tópicos del policial). Menciona, por ejemplo, el peligro de la "habitación herméticamente cerrada" (49) (un clásico del policial), y tememos que algo suceda en el cuarto de hotel, en otra ocasión le advierte que su vida está en peligro, entonces Udo al mirar al Quemado desde la ventana sentencia "Por un momento me dominó el miedo; supe que allí estaba el peligro y la muerte" (85). Todas las intervenciones de Linden tienen que ver con un crimen ya cometido, con la presencia de un asesino. Las páginas que por azar lee Udo son mensajes encriptados de algo que hay que descifrar, "Usted afirma haber repetido varias veces el mismo crimen. No, no está usted loco. En eso precisamente consiste el mal" (126). Son claves que encierran al relato aún más en la atmósfera del policial pero que, sin embargo, despistan como por ejemplo cuando lee -nuevamente por azar- "El asesino es el dueño del hotel" (194) 
Tenemos entonces una serie de hechos y percepciones revestidos de la presencia del miedo y del peligro junto con diversos enigmas que surgen como piezas de un rompecabezas que el lector intentará armar. Está la desaparición de Charly, que luego aparece ahogado; tenemos la posible violación que podría perjudicar al Lobo y al Cordero, mas luego implica a Charly como víctima, está la magnética encargada del hotel, Frau Else, de cuyo misterio y belleza Udo parece enamorarse, y su esposo enfermo, oculto siempre entre las sombras. Sin embargo todo se diluye, nada adquiere la importancia narrativa que estanque al relato pues el misterio más importante es el del Quemado, es lo único que a Udo le interesa. Así el foco de la historia regresa siempre a este extraño personaje y todo lo que provoca en Udo. Se entremezclan la repulsión y el prejuicio con una fascinación y una curiosidad que lo llevan a querer acercarse y conocer su historia. Sabemos que es sudamericano, que sus heridas son producto de la tortura pero no importa tanto la información sobre él, que es casi nula, sino lo que desencadena en Udo. Un estado de alerta y terror, "pude oler la violencia que nos estaba rodeando” (129), “¿por qué a veces tengo tanto miedo?” (98). El Quemado instala la sospecha de que algo se mantiene oculto.

En su "Tesis sobre el cuento" Ricardo Piglia afirma que la forma del relato está dada por las combinaciones que se establecen entre las dos historias que todo cuento sostiene, una visible y otra oculta. Así la tesis de las dos historias cifra la estructura básica del relato policial: el enigma al final es develado. En la versión clásica "el final de la historia secreta aparece en la superficie". Luego la reformulación de la teoría del cuento sistematizada por Piglia desplaza el modelo de Edgar Allan Poe donde el efecto es motor y justificación del relato. Entonces, el cuento en su versión moderna "abandona el final sorpresivo y la forma cerrada", "la historia secreta se construye con lo no dicho, el sobrentendido y la alusión" (Piglia, 2000). La síntesis de esta forma es la teoría del iceberg de Ernest Hemingway, según la cual lo más importante nunca se cuenta pero se deja entrever y adivinar desde algunos datos o alusiones. El principio del iceberg formulado por Hemingway coloca la fuerza del relato en la elipsis de lo conocido, "el conocimiento es lo que constituye la parte del témpano que está bajo el agua" (Hemingway, 1953), lo que se cuenta es sólo la punta del iceberg. En la economía narrativa de Hemingway lo que no se dice llega de todas maneras al lector, pues es una omisión voluntaria de lo conocido, pero también aquello no se dice es lo que sostiene el relato. Bolaño parte de esta idea de la historia superficial o la punta del iceberg y de lo oculto o lo sumergido pero la reconfigura como el principal dispositivo narrativo que 
pone a funcionar en la novela. Y, siguiendo a Piglia, la mejor manera de ponerlo en funcionamiento es activando el código del policial.

La operación que se realiza con la figura que trabaja la teoría de Hemingway nos lleva a La pista de hielo. Bolaño desarma el sistema del iceberg que establece una superficie visible y reenvía a lo que permanece velado al romper con esa conexión que articula lo que se dice con lo que se oculta. Es decir, con la punta del iceberg el texto sostiene algún tipo de acceso a la profundidad, lo soterrado se interpreta a partir de lo que se ve (o se relata). En cambio, Bolaño cambia el iceberg por la "pista de hielo" y aplana todo acceso a ese núcleo oscuro de modo que solo es posible deslizarse por la superficie, y no encontrar nada porque no hay modo de ingresar.

Sabemos, o esperamos, que algo va a suceder en cualquier momento, y abre grietas en el relato que se dilata y entonces la ilusión de una linealidad que forzosamente debiera llevar a la revelación de un enigma se quiebra y deja de existir. Entre otras, las principales características apuntan al final abierto, a la falta de resolución de un misterio que no se devela porque está demasiado oculto y un final sorpresivo en tanto decepciona al lector y a veces hasta al mismo narrador. La lógica de la ficción ya introducida la modalidad del policial constantemente se rompe, renueva y sustituye el tácito pacto de que "algo va a suceder" (Martínez 1998).

Poco a poco, Udo adquiere un aspecto enfermizo reflejo de su especie de obsesión por el Quemado, que lo consume y el relato parece bifurcarse en un doble plano en el que convive lo banal con el horror. La tensión entre la historia superficial y la historia oculta dan cuenta del elemento ominoso que atraviesa toda la novela pero no se accederá al núcleo que lo conforma porque el texto elimina la pista. Por un lado, está el transcurrir de la acción, el narrar diario de las actividades del grupo en el hotel, en la playa, las salidas nocturnas. Historias típicas de vacaciones, la rutina del Quemado que tanto preocupa a Udo no reviste nada extraño: alquila los patines, duerme, vive en la playa, en el refugio que él mismo arma con ellos. Por otro lado, no obstante, hay un halo perturbador que se vislumbra desde las fisuras que Udo percibe, en las cifras de un peligro que acecha, en las instancias más triviales. Por ejemplo, el grupo asiste a un bar donde televisan un partido de fútbol en el que la selección de Alemania Oriental es derrotada por dos a cero; este dato encarna en Udo "como una inflexión en la noche, como si a partir de aquel momento toda la jarana de la discoteca pudiera transformarse en algo distinto, en un espectáculo del horror" (54). Por supuesto, nada sucede. Es así que se abre un haz de matices semánticos relacionados con la derrota, el peligro, el 
horror que sólo anclan en la perturbada sensibilidad de Udo. La escena del corno del peligro es clarificadora (enlaza la cadena Udo-nazis-peligro): Udo escucha el sonido de un corno, "el aviso de los antepasados, la voz de la sangre que te pone en guardia" (74) según el recuerdo del brutal general nazi Sepp Dietrich, en quien Udo estaba pensando y se pregunta: “¿sonó el corno, entonces, en mi mente? ¿contra qué peligro pretendía ponerme en guardia?” (75)

Este sentimiento ominoso persigue a Udo (y alerta al lector) tal como manifiesta en un diálogo que sostiene con Frau Else "Y si te digo que siento algo intangible, extraño, dando vueltas a mi alrededor, amenazante ¿me crees?” (241), es un miedo que lo encadena, por eso, abandona todo (las vacaciones terminaron, todos regresan a sus rutinas) y Udo se queda para consumar una partida del Tercer Reich con el Quemado. El juego es como un mandato que debe cumplir.

El juego se vuelve cada vez más peligroso cuando advierten a Udo que renuncie, que por su bien no se meta con el Quemado. Adquiere dimensiones simbólicas cuando le cuentan que las quemaduras le fueron provocadas por "los verdaderos nazis que andan sueltos por el mundo" (230), que el Quemado había sido un soldado "luchando a la desesperada" (230) y que ahora era un fantasma (232) Pero el dato más inquietante lo proporciona el misterioso marido de Frau Else cuando insinúa que el Quemado tenía planes macabros para Udo que excedían el juego, “en las pesadillas de ese pobre muchacho el juicio es tal vez el acto más importante del juego, el único por el que vale la pena pasarse tantas horas jugando. ¡Colgar a los nazis!” (325)

Es aquí cuando el epígrafe de Dürrenmatt ilumina los hilos de la trama que une sólo a Udo y al Quemado. Al final, las predicciones no se cumplen, el Quemado no cuelga a Udo, ni lo golpea hasta desangrarse, simplemente lo derrota en su propio juego y lo obliga a experimentar el miedo visceral del condenado. En la última noche de Udo en la playa, en medio de una tormenta, el alemán es llevado violentamente hacia el interior de la fortaleza de patines como si entrara en el túnel del tiempo, "vi al Quemado yéndose del pueblo y del país por un camino zigzagueante hecho de dibujos animados y pesadillas (...) como el eterno doliente” (347) “Afuera el Quemado se reía”...

Finalmente no se comete ningún crimen, pero al refuncionalizar los elementos que remiten al código del policial entendemos que el crimen nunca se concreta en el texto porque ya ha sido cometido. Son los crímenes de la historia, de los cuales el Quemado es memoria viviente. La justicia -que en la melancólica condición de paria del Quemado parece tener las aristas de la revancha, nunca de la venganza -se ensaya en el 
tablero de juegos y se vislumbra en la escritura de Udo que se sabe derrotado, se ha vuelto el vencedor vencido. Sin embargo del tenso enfrentamiento final volvemos a las más trivial cotidianeidad de Udo, regresando de sus vacaciones, por la autopista. No sin antes haberse despedido a su modo de su gran contrincante: le regala al Quemado el Tercer Reich. Luego aparecen retazos sin importancia, pequeñas informaciones sobre el destino de los personajes (como el anexo de Monsieur Pain).

Cuando Joan Ramon Resina reconstruye el panorama de la novela policiaca española explica la ausencia del género durante los primeros años de la postguerra a través del siguiente interrogante: “¿qué interés puede despertar la violencia oculta en una sociedad constituida por una violencia transparente?" (Resina 1999: 44). Si traducimos la pregunta a la realidad de las dictaduras en el Cono Sur, sin embargo, los términos se invierten para señalar una violencia que el Estado ejerce en la clandestinidad, en los centros clandestinos de detención, el sótano de una casa como sala de torturas (Nocturno de Chile). El Tercer Reich se publica póstumamente pero Bolaño lo había imaginado en 1989. Argentina y Uruguay ya habían comenzado a transitar la democracia, en Chile la palabra dictadura agonizaba, no así sus consecuencias, ni su estructura legal y política. El estado de alerta constante desplegado por el código policíaco da cuenta de los dobleces de una realidad construida, para delatar las zonas que la apariencia quiere ocultar, así como los centros clandestinos de tortura intentaban camuflarse en los espacios de una ciudad militarizada. El Quemado se refugia en su fortaleza de patines pero las marcas en su cuerpo torturado no pueden ocultarse.

Los elementos del código de la narrativa policial que Bolaño pone a funcionar en los engranajes de sus relatos parecen apuntar a ese vacío horroroso que los estados latinoamericanos instalaron, esa insistencia en el crimen, y el peligro convoca la imperiosa necesidad de llenar los huecos de la historia, en los procesos de articulación de una memoria que necesariamente lleve a la justicia. En su teoría del iceberg Hemingway advertía que omitir lo desconocido genera agujeros en el relato (Hemingway 1953) y son estos agujeros los que permiten el ingreso del lector en la construcción literaria. Es el lector quien intenta una y otra vez llenar los agujeros del relato. La pista de hielo de Bolaño, como dijimos, solo permite el deslizamiento a la deriva o la vuelta en círculos que no conduce a nada, porque la superficie resbaladiza del policial no permite desentrañar lo oculto. 
En El Tercer Reich, atisbo temprano de los temas y tonos que la narrativa de Bolaño plasmará vigorosa y visceralmente luego, esto se da no sólo a partir de personajes 'con pasado' como el Quemado, o los usos del policial sino también mediante otros guiños al lector, como el epígrafe de Dürremantt. La vuelta de tuerca provocada por la estética de Bolaño instala repetidamente la cuestión de la memoria, de la justicia. A través de la lógica del policial la novela fragua en el lector la teoría del iceberg, y las tesis sobre el cuento de Piglia, para luego traicionarlas: no sabemos que hay debajo del icerberg porque se ha transformado en pista de hielo, la historia secreta permanecerá oculta pero contaminará la superficie. La lucha mental -simbólica- entre Udo y el Quemado cifra las batallas de la historia occidental en el arco que une el horror sudamericano con Europa, que bajo la lente de Bolaño se reduce a un juego de temporada, en la costa catalana porque ya no puede haber lugar para grandes gestas, en una Europa "amnésica, sin épica y sin heroísmo" (118).

Las rescrituras del fantástico y el policial- dos modalidades divulgadas por Borges- se enmarcan en una revisión más amplia de las generaciones literarias anteriores a Bolaño, particularmente del universo cultural del boom. Creemos que la potencialidad de la narrativa bolañana reside en esa implosión que realiza al interior de la literatura latinoamericana para expandirse al resto del mundo occidental. Si de precursores se trata, la figura de Borges se instala como epicentro del huracán Bolaño para dar cuenta de las posibilidades 'universales' de la literatura por encima de fronteras geoculturales. Sin embargo, para Bolaño, a diferencia de Borges, su puerto de partida siempre es América Latina y sus intereses giran en torno de la historia y la política, antes que la filosofía. Los ecos de Borges resuenan en toda la narrativa de Bolaño, como constataremos una vez más en 2666. 


\section{REINSCRIPCIONES DE LA MEMORIA EN EL PRESENTE DE AMÉRICA}

\section{LATINA: 2666}

Que la amnesia nunca nos bese en la boca. Que nunca nos bese

Roberto Bolaño, Déjenlo todo nuevamente

La violencia y el mal han sido los ejes desde los cuales se han organizado las lecturas críticas de 2666, sobre todo a partir del capítulo que lista los cuerpos mutilados, violentados y abandonados en el desierto de las mujeres asesinadas en Santa Teresa, "La parte de los crímenes". ${ }^{160}$ No es ninguna novedad que Bolaño estuvo interesado en documentarse e informarse acerca de los crímenes de Ciudad Juárez, en México, ${ }^{161}$ y que Santa Teresa figura esa ciudad fronteriza, el escenario de más de setecientos feminicidios, siendo el período más feroz desde 1993 a 2003 (Del Sarto 2012: 54). Esta forma de violencia asociada al crimen, desde las esferas del poder (político, económico -e ilegal) convive en la novela con otros tipo de violencia. Una es la política, la ideológica y la otra es la simbólica, la que se escurre entre los personajes, permea espacios y atmósferas. En una confluyen los crímenes de la historia, la otra se instala en el presente continuo de la existencia y ambas son elaboradas a partir de la reflexión del lugar de la cultura, del arte y la literatura en semejante oasis de horror. Además, precisamente porque ese horror es constitutivo del "abismo que nos rodea" (Bolaño 2003: 215) y llamamos América Latina, 2666 es también un engranaje más que Bolaño pone a funcionar en su máquina trituradora $\mathrm{y}$ recicladora de tradiciones. ${ }^{162}$

\footnotetext{
${ }^{160}$ Entre otros nos referimos a los trabajos de Cánovas (2009), Candia (2006, 2010), Huneeus (2011) o González (2011).

161 "Hace algunos años, mis amigos que viven en México se cansaron de que les pidiera información, cada vez más detallada, además, sobre los asesinatos de mujeres de Ciudad Juárez..." cuenta Bolaño (2004: 214) al comenzar su reseña del libro de Sergio González Rodríguez, Huesos en el desierto crónica de los crímenes y fuente de 2666 (la figura ficcionalizada de González Rodríguez también aparece en la novela).

${ }^{162}$ Creemos que el epígrafe de Baudelarie que abre la novela puede leerse autorreferencialmente. Es la novela de Bolaño el oasis, de horror por supuesto (cómo no serlo si aborda el nazismo, los feminicidios de Juárez), que aparece en medio del desierto de aburrimiento que implicó la literatura latinoamericana dedicada a repetir formulaicamente los epígonos del boom, la última gran generación literaria. Es 2666 la
} 
Exploraremos los modos en que la violencia (y sus derivas -el crimen, el mal) se instala como eje omnipresente no sólo en la representación de América Latina sino también en su tradición literaria, en las posibilidades de la literatura misma y en sus vínculos con la historia reciente. Tres conceptos se ponen en movimiento -barbarie, mal, violencia- a partir de distintas matrices de pensamiento, todos apuntan sin embargo a un mismo verdugo, al que hay que desencapuchar: la oculta cara de la razón, el progreso, la modernidad. ${ }^{163}$ Y, como señaló Georges Bataille, la literatura no es inocente (2000: 23)

\section{1. Cultura y barbarie}

Uno de los pasajes más citados de las "Tesis de filosofía de la historia" de Walter Benjamin es sin duda el que revela el legado de la violencia opresora en los bienes culturales de la humanidad, el que nos recuerda que cultura y barbarie son una unidad contradictoria y no polos excluyentes, o etapas diferentes del progreso histórico. Bolaño no se cansa de actualizar la Tesis VII ${ }^{164}$ y a lo largo de más de mil páginas explora los vínculos entre el mal, la violencia y la literatura, ensaya diversas figuras de escritor (y lector) para pensar posibles salidas (o entradas) del abismo al mismo tiempo que traza los perfiles más oscuros del mapa latinoamericano, que es también sólo un oasis de horror en el mapamundi de Occidente.

En la primera parte de la novela, "La parte de los críticos", cuatro académicos europeos especializados en la obra del escritor alemán Benno von Archimboldi emprenden una búsqueda fanática del desaparecido autor, retomando una obstinación bolañiana: el misterio del escritor faro y perdido en algún rincón del planeta. ${ }^{165}$ Ese será uno de los hilos conductores que unan las partes autónomas de 2666 que confluyen en la ciudad de Santa Teresa, esa ciudad de frontera donde se insiste en el cruce entre violencia y modernidad (de la cual nos ocuparemos más adelante).

que amalgama la tradición aventurera y apocalíptica que Bolaño rescata como las únicas posibles en el fin de siglo latinoamericano (2003: 215).

163 Reyes Mate resume: "Si buceáramos tras las esencias de Occidente (Dios, hombre, mundo), descubriríamos una sarta de intereses inconfesables (poder, dominio, dinero), cuyo precio ha sido declarar desechable otros elementos conceptuales menos glamurosos (el sufrimiento, la pobreza, la esclavitud)". "La violencia que nos ata", El País, 30 junio 2008.

${ }^{164}$ Ignacio López Vicuña, "Desdoblamientos literarios: Bolaño entre la civilización y la barbarie”, 2012 : 101)

${ }^{165}$ Cesárea Tinajero es su precursora más fiel y si la búsqueda que Lima y Belano emprenden en Los detectives salvajes no finaliza exitosamente ("Cesárea Tinajero es el horror", le anunciaba Ernesto San Epifanio a García Madero (Bolaño: 1998 85) el resultado de ésta no será diferente. 
La relación que une a los cuatro críticos no es solamente académica, hay una triángulo amoroso entre la inglesa Liz Norton con sus pares francés y español, Pelletier y Espinoza, que termina cuando Norton elige al profesor italiano Morini. El mundo de la literatura encerrada en congresos y conferencias universitarias es el otro lado del campo literario de los noventa que la segunda sección de Los detectives salvajes pone en escena. Si aquí prevalecen, con ironía y burla, los modos y modas de la academia (como por ejemplo el desdén por la literatura alemana frente al éxito de las letras inglesas particularmente desde el prisma poscolonialista) ${ }^{166}$ en Los detectives salvajes la literatura se desdibuja en las imposturas del mercado editorial, las ferias de libro, los premios. Este mapa europeo de especialistas en literatura está plagado de convenciones, futilidades del mundo universitario pero al mismo tiempo las rutinas académicas se van impregnando de un halo extraño, entre misterioso y a veces violento, a partir de la decisión de encontrar el paradero de Archimboldi. Aparecen las pesadillas (como la de Morini, primero en leer sobre los asesinatos de mujeres en Santa Teresa, 64), las veladas batallas por el amor de Liz Norton (como el deseo fugaz de Pelletier de que un avión estrellado fuese el de Espinoza, 83) y los repetidos encuentros en simposios y conferencias van transformándose en torbellinos de celos, paranoias y miedos.

La escena del taxista paquistaní es sin duda la más importante en esta primera parte pues resume el modo en que la novela exhibe la amalgama entre literatura y violencia, esa aleación sólo permeada por el humor, el sarcasmo y la ironía que en todo Bolaño funcionan como fuerzas erosivas que provocan distancia y permiten la crítica. Resulta que Espinoza y Pelletier visitan a su amante en Londres dispuestos a impedir que un cuarto en discordia (Pritchard, amigo de Liz Norton) se incorpore a su triángulo amoroso. Un viaje en taxi se convierte en la peor pesadilla del conductor a quien los profesores universitarios golpean ferozmente, insultan e incluso roban su auto para escapar. En un principio, el origen de semejante acción pareciera ser una reacción para defender a Norton, a quien el taxista paquistaní insulta en nombre de la dignidad y castidad femenina. Sin embargo, a medida que los golpes intensifican su brutalidad la violencia se confunde con el placer y parece ser éste el motor del acto.

La relación entre violencia y placer nos lleva a las reflexiones de George Bataille sobre el funcionamiento del Mal en la literatura y su poder para representar las pasiones.

\footnotetext{
${ }^{166}$ En un coloquio sobre literatura contemporánea la literatura alemana pierde ante la inglesa en cantidad de público "cuya asistencia masiva al diálogo inglés (o angloindio) era notablemente superior al escaso y grave público que acudía al diálogo alemán” (32, cursivas nuestras).
} 
El verdadero Mal, señala Bataille pensando en Emily Brontë, es el del goce ante la contemplación de la destrucción misma (30). Sin embargo el acto de violencia contra el paquistaní, orgásmico y pasional para los perpetradores, ${ }^{167}$ nunca rebasa los límites de la razón ni les hace perder la calma, al punto de no olvidar el detalle de borrar sus huellas del taxi. ${ }^{168}$ No sufren ningún rapto que los impulse a proceder de manera contraria a su voluntad, aunque esa haya sido la justificación de Espinoza, "por un pronto" (107), explica.

Se trata de lo que magistralmente Edgar Allan Poe llamó "the imp of the perverse", esa parte racional que, aunque oculta, incita a hacer el mal por el mal. Esto no implica una concepción del mal como algo natural, innato o propio de la esencia humana sino que llama la atención sobre aquellas formas del mal que provienen de los pilares que sostienen una racionalidad extrema que vuelven la mirada sobre el 'cómo es posible' y atenta contra la idea fácil de enfrentar el mal con un opuesto, el bien. No olvidemos que el narrador del relato de Poe, extremadamente lúcido y metódico, es un asesino justificando sus hechos desde una celda. En 2666, el episodio de violencia xenófoba es protagonizado por profesores universitarios evocando a Borges o al "más bien malo" (103) Salman Rushdie. A partir de la imagen del laberinto, "que mucho antes de Borges Dickens y Stevenson se habían referido a Londres utilizando ese tropo" (102) se desata la pelea y los eminentes críticos literarios atacan cruelmente al extranjero sin sustraerse a su profesión, sin perder el control de sí.

Tampoco estamos ante el mal definido desde la perspectiva cristiana ni burguesa $^{169}$ que lo encierra más allá de los confines de la razón, en una otredad carente de lo que se considera el Bien. Hannah Arendt también insistía en que la violencia es deudora de la civilización y el progreso, por lo tanto no es ni bestial ni es irracional (1970: 84). El violento ataque al taxista perpetrado por universitarios confirma las derivas oscuras de la cultura enclaustrada en la academia, embalsamada en vitrinas de moda y conformismo - una visión de la intelectualidad que Bolaño recurrentemente critica. Su contracara es la melancólica actitud de Amalfitano, "el soldado raso de una

\footnotetext{
167 "Pelletier se sentía como si se hubiera corrido. Lo mismo, con algunas diferencias y matices, Espinoza. Norton (...) parecía haber experimentado un orgasmo múltiple" (103)

${ }^{168} \mathrm{Si}$ la violencia xenófoba contra el taxista desata deseos ocultos en los europeos, el hecho no se ubica dentro de la esfera de lo irracional. Cf. “¿De qué hablamos cuándo hablamos del mal?: 2666”, Marcial Huneeus: 2011 257-259)

${ }^{169}$ Georges Sorel rechaza la concepción de violencia que la "filosofía burguesa derramara por el mundo; pues según ella, la violencia es rezago de la barbarie y está llamada a desaparecer por el influjo del progreso" (1907: 75). En Bolaño no hay una visión nostálgica ni condescendiente de la lucha armada, pero sí una mirada crítica a los restos del progreso, a las ruinas de la historia.
} 
batalla perdida de antemano contra la barbarie" (152) quien resume la cuestión en la radiografía de la ciudad letrada mexicana que describe a los profesores europeos. La diferencia está en los intereses, unos se preocupan por sobrevivir, a otros les interesa escribir (160), reflexiona. El pasaje discute la relación del poder y la cultura actualizando el mito platónico de la caverna- donde priman la falsedad y los intereses propios. La cultura se parece a un escenario montado para unos pocos o es una caverna, una mina desde donde los intelectuales sin sombra tratan de interpretar los ruidos que provienen de afuera y sólo consiguen domesticarlos, tergiversarlos. ${ }^{170}$ Amalfitano define con un gesto duchampsiano (245) la literatura en las antípodas de su enclaustramiento en universidades, congresos y coloquios. Se trata de la literatura a la intemperie, como el libro Testamento geométrico de Rafael Dieste que cuelga de la cuerda para la ropa para ver cómo resiste los embates del desierto (246), como el viento que sopla cuando la policía de Santa Teresa encuentra los cadáveres de las mujeres asesinadas (260). ${ }^{171}$

En el comienzo de la novela Bolaño juega con ese modo borgeano de deleitarse con el detalle de ediciones y lecturas de libros inexistentes para desnudar los hilos que sostienen la crítica literaria más banal y caníbal. Los detalles absurdos, el desmesurado hincapié en los datos más triviales a través de una prosa ordenada, casi obsesionada por las estructuras revelan, con tono irónico, la labor del crítico que coloca la literatura bajo la lupa, en una mesa de disección. Un ejemplo entre varios es la conversación telefónica entre Pelletier y Espinoza que se relata atendiendo a la duración de la llamada, o la cantidad de veces que se mencionan palabras (61-62). El estilo de "La parte de los críticos" ensaya la crítica del facsímil, "sólo un ojo que busca los elementos tangibles y no los juzga sino que los expone fríamente, arqueología del facsímil y por lo mismo arqueología de la fotocopiadora" (79), que los personajes critican con referencia a la edición sobre las minucias de la vida cotidiana del marqués de Sade (sus recetas médicas, su paso por la lavandería, etc). El objetivo sería documentar la mera existencia

\footnotetext{
170 "Su trabajo (...) es pobrísimo. Emplean la retórica allí donde se intuye un huracán, tratan de ser elocuentes allí donde intuyen la furia desatada, procuran ceñirse a la disciplina de la métrica allí donde sólo queda un silencio ensordecedor e inútil" (162-163).

${ }^{171}$ Amalfitano define las grandes obras (frente a obras menores) como "combates de verdad, en donde los grandes maestros luchan contra aquello, ese aquello que nos atemoriza a todos, ese aquello que acoquina y encacha, y hay sangre y heridas mortales y fetidez" (290)
} 
del escritor tal como lo intentan hacer los cuatro académicos empecinados en encontrar a Archimboldi. ${ }^{172}$

En la segunda parte, por el contrario, predomina el tono melancólico de Amalfitano, un lenguaje poético más afín a los pilares que definirán al escritor bolañano: la locura, la tristeza, la derrota, a través de una prosa plagada de metáforas. ${ }^{173}$ Aquí se exploran otras relaciones con la literatura que atraviesan imágenes de lo mutilado (como el pintor Edwin Jones de la primera parte), o tullido (como Morini), la locura (Lola y el poeta en Mondragón), la melancolía y lo marginal (Amalfitano).

Óscar Amalfitano es un profesor chileno de literatura exiliado en España de donde debe marcharse por un suceso relacionado con su velada homosexualidad. Termina en la universidad de Santa Teresa con su hija, Rosa, entre los fantasmas que escucha (hay una voz con la que dialoga y parece ser su padre muerto) y los que recuerda de su pasado. Como Lola, su mujer, cuya historia de alguna manera es espejo de la primera parte en tanto cifra también la historia del lector obsesionado por un escritor, lo que desata la "búsqueda del autor". Ella decide abandonar a su familia (Amalfitano y la pequeña Rosa) para ir en busca de su poeta favorito -y amor de juventud- quien está recluido en el manicomio de Mondragón. ${ }^{174}$ La diferencia con los críticos de la primera parte, radica en que Lola, luego de atravesar diversas complicaciones, se encuentra con el poeta pero es incapaz de reconocer el desdén con que es recibida, producto sobretodo de la delirante locura del autor ("que la ignoraba olímpicamente", 227). Pareciera que todo contacto entre lectores y escritores redunda en el más absurdo fracaso porque al fin y al cabo la relación más verdadera se entabla con la literatura misma. Es por ello que la novela también se detiene en los modos para sondar el complejo entramado de las palabras y las cosas.

"La parte de Amalfitano" corroe, también con un guiño a Borges, los sistemas de lectura que la filosofía ensaya para interpretar el mundo. Son los esquemas geométricos con nombres de filósofos que Amalfitano lista en el aburrimiento de una

\footnotetext{
172 Aunque sostengan que "hay que hacer investigación, crítica literaria, ensayos de interpretación, panfletos divulgativos (...) pero no este híbrido entre fantaciencia y novela negra inconclusa" (83) casi en una puesta en abismo de lo que ellos mismos hacen con Archimboldi durante todo el capítulo.

173 Así, por ejemplo, se describe una cena informal con miembros de la universidad donde Amalfitano trabaja: "La cara del rector (...) manifestó un miedo súbito que duró lo que dura el aleteo de una mariposa. Pero Amalfitano lo notó y por un instante (el segundo aleteo) el miedo del rector estuvo a punto de rozarle también a él la piel. Cuando se recuperó y miró a los demás comensales se dio cuenta de que nadie había percibido esa mínima sombra como un hoyo cavado aprisa y de donde se desprendía una fetidez alarmante", (281).

${ }^{174}$ Se ha identificado al personaje con el poeta español Leopoldo María Panero.
} 
clase e intenta luego dar sentido o la evocación de los inútiles intentos de Ramón Llull por explicar verdades. ${ }^{175}$ La máquina lógica que el filósofo mallorquín Ramón Llull ideó más para clasificar que conocer el mundo y llegar a las verdades de Dios se menciona para disparar la lectura cómplice que conoce los irónicos reparos de Borges a las clasificaciones arbitrarias que interpretan el mundo, cuestionando así los supuestos de verdad, orden, conocimiento y realidad (Guízar, 2004: 94). Si de esquemas para explicar al mundo se trata, precisamente el libro de Dieste que soporta a la intemperie las inclemencias del tiempo es un tratado de geometría. Y el gesto vanguardista que Amalfitano recupera pareciera reconocer por lo bajo el sinsentido de encasillar al mundo en teorías, especulaciones, leyes o catálogos. Tan absurdo como el libro de Lonko Kilapán sobre el origen araucano de O’Higgins y el origen griego de los araucanos que culmina con la telepatía de los mapuches o la posibilidad de que Kilapán sea "un nom de plume de Pinochet" (286) o de Aylwin o de Lagos.

Entonces no sólo se cuestiona la posibilidad de agotar toda obra literaria a través del trabajo crítico y sobre todo explicarla a la luz de su autor en tanto persona física (tal es la obsesión de "La parte de los críticos": el interés por ver o conocer personalmente a Archimboldi) sino también los intentos por dar cuenta de las verdades del mundo a través de estructuras y postulados. ${ }^{176} \mathrm{Al}$ fin y al cabo qué importancia tiene la pregunta inicial del capítulo, cuya respuesta Amalfitano ignora (qué ha venido a hacer a Santa Teresa, 211), cuando aparecen en el desierto los cadáveres de las mujeres asesinadas.

Otra pregunta -pero la misma desazón- inicia el capítulo siguiente, "La parte de Fate", y constituye otro paso más cerca del horror que fue filtrándose en las páginas precedentes. “¿Cuándo comenzó todo? (...) ¿En qué momento me sumergí?” (295), así se presenta el narrador al protagonista, como transcribiendo una suerte de breve monólogo interior que alude a sus pesadillas, fantasmas y dolor. Luego conocemos que Quincy Williams, de treinta años, es un periodista conocido como Oscar Fate, su madre acaba de morir y le ofrecen reemplazar al encargado de la subsección de boxeo recientemente asesinado en Chicago. Antes, con un tono rápido $\mathrm{y}$ descriptivo accedemos a la especialidad de Fate: las notas a personajes olvidados que han tenido un

175 "Recordó (pero como de pasada, como se recuerda un rayo) a Raimundo Lulio y su máquina prodigiosa. Prodigiosa por inútil” (265).

${ }^{176}$ Bolaño transcribe de la biografía de Calvin Tomkins sobre Marcel Duchamp (que Anagrama publica en 1999) el ánimo transgresor que Amafiltano melancólicamente homenajea con Dieste:"había disfrutado desacreditando "la seriedad de un libro cargado de principios"' (246) Y Borges clarifica respecto de la inútil "máquina de pensar de Lulio": "tampoco funcionan las teorías metafísicas y teológicas que suelen declarar quiénes somos y qué cosa es el mundo", en "La máquina de pensar de Raimundo Lulio", Textos cautivos (1937). Ver también: Borges "Nota sobre (hacia) Bernard Shaw", Otras inquisiciones, (1951) 
pasado de activismo y compromiso pero ya residen en los márgenes de la decadencia, como un ex pantera negra aficionado a la cocina en Detroit o el único miembro del partido comunista de Brooklyn. Los libros, sus comentarios y transcripciones también se destacan en esta parte, en especial La trata de esclavos de Hugh Thomas que Fate lee y el narrador reproduce. Los pasajes revelan la violencia de la esclavitud en una prosa desafectada que describe el comercio de seres humanos con sencillez y precisión, como una práctica naturalizada y amparada en la racionalidad del siglo XVIII. Este libro es el que Fate lee en el viaje a la frontera mexicana que cambiará su rumbo.

Con la idea de cubrir la pelea de boxeo entre un tal Count Pickett y un mexicano, Fate llega a Santa Teresa y la narración dejará por momentos el estilo estadounidense (casi de traducción hispana ${ }^{177}$ ), llano y coloquial. El relato se abrirá hacia las zonas oscuras de las sensaciones del periodista al mismo tiempo que el personaje se involucra en la noche ilegal y viciosa de Santa Teresa. Ya las primeras impresiones camino a la ciudad anuncian la muerte, se suceden las comparaciones macabras, ${ }^{178}$ y una reiterada sensación de irrealidad invade a Fate. No es casual que su vocación de escritor, que canalizará en el periodismo, sea la que lo lleve a involucrarse en la investigación de los crímenes de Santa Teresa y a ayudar a Rosa Amalfitano a escapar de la ciudad o a su colega Guadalupe Roncal a afrontar el encuentro en la cárcel con el presunto asesino. Así el estilo periodístico (de oficinas de redacción, despachos de detectives o encuentros callejeros) por momentos se diluye para dar lugar a la voz del propio Fate trastornada y perpleja, tal como había comenzado el capítulo. El extranjero (en duelo por la muerte de su madre, como otro extranjero: el Mersault de Albert Camus), un afroamericano con ganas de ser escritor e interesado en temas sociales, nos introduce en la siguiente sección.

“La parte de los crímenes" recorre en más de trescientas páginas el desierto poblado de cadáveres de las jóvenes asesinadas en Santa Teresa. El narrador elige comenzar el relato con el hallazgo de la primera muerta de 1993, Esperanza Gómez

\footnotetext{
${ }^{177}$ Es magistral el pasaje en el que Fate discute con su editor y le pide dejar de cubrir el boxeo para orientar su artículo a los asesinatos y la realidad en la frontera, "el mundo industrial del Tercer Mundo" (373) donde el exagerado uso de insultos adjetivados parodian las traducciones del inglés de términos como "fucking", "shit" o "motherfucker", tan usados sobre todo en las representaciones estereotipadas de afroamericanos (pág. 373-374).

${ }^{178}$ Como: "no se veía ninguna luz, como si los habitantes hubieran muerto esa misma noche y en el aire todavía quedara un hálito de sangre" (342), o cuando llama a su oficina en los Estados Unidos la voz que atiende "no hablaba como una secretaria neoyorquina sino como una campesina que acabara de salir de un cementerio" (347).
} 
Saldaña, ${ }^{179}$ y la lista pasará ante el lector como si en vez de estar leyendo una novela se estuviera mirando las fotos de un informe forense de las que, sin embargo, se desliza un resto que sacude el "mal de archivo" (Derrida) de las imágenes sepultadas por instituciones amnésicas. El detalle alterna entre dónde se encontró el cadáver, por quién, qué heridas o vejaciones presenta y su identificación, en la medida de lo posible. Esta sucesión macabra de cuerpos, descriptos con un lenguaje desafectado, citando los registros médicos y policiales (muchas veces el narrador explicita que así lo indican dichos informes) no intenta explicarse los crímenes ni investigar culpables sino sólo muestra a las víctimas. En una sociedad que las invisibiliza ${ }^{180}$ se trata de imponer sus presencia a través de la lista interminable que detalla los horrorosos hallazgos. Si el principio de la repetición no llega a desgastar el mecanismo es porque se salva ese riesgo, el del hartazgo, con la peculiaridad de cada asesinato, lo particular de cada víctima. Por lo tanto, al mismo tiempo el catálogo se desliza desde el informe forense o la crónica policial periodística hacia el documento con valor testimonial para desprenderse así de la mecánica administrativa de acopio, registro y también olvido. Nuevamente tenemos la presencia del testimonio en los textos de Bolaño que se articula con la ficción, como vimos. En este caso se apela al más crudo documento como garantía de la "verdad".

La acumulación de los detalles permite la visión del cadáver pero, como advierte Georges Didi-Huberman (2007), sólo son los jirones o fragmentos de una imagen o un archivo que la voz narrativa recupera para trabajarlos desbordando lo real y transformando el archivo en testimonio. Si como sugiere el análisis de Giorgio Agamben (2000) el archivo supone la reducción del sujeto a un función al margen que desaparece "en el rumor anónimo de los enunciados", el salto al testimonio intenta volver a colocar al sujeto en su puesto, aun sabiéndolo vacío. El narrador apela al archivo no sólo para dar testimonio del horror al que fueron sometidas las mujeres sino también para enunciar el horror que siguen padeciendo: la desidia social y la inercia de las autoridades tanto para esclarecer los crímenes como para evitarlos. Es el intento de convertirse en la voz que exhuma del olvido a las víctimas en la persistencia -de más de

\footnotetext{
179 “Aunque seguramente en 1992 murieron otras. Otras que quedaron fuera de la lista o que jamás nadie las encontró, enterradas en fosas comunes en el desierto (...)" (444)

${ }^{180}$ Sólo un ejemplo: "sobre la camilla (...) iba el cadáver de Emilia Menan Mena. Nadie se fijó en él" (466)
} 
trescientas páginas- por desclasificar los documentos forenses o policiales para sustraerlos de su anquilosada existencia de rutinas y silencios encajonados. ${ }^{181}$

Es un trabajo de memoria que con las apariencias de un informe, o una crónica para el futuro, sostiene la tensión entre narración y documento ${ }^{182}$ para que las mujeres de Santa Teresa no formen parte del cementerio del olvido del año 2666, tal como había vaticinado Auxilio Lacouture en Amuleto, o Césarea Tinajero en Los detectives salvajes. En estas novelas anteriores se anuncia el título como una profecía macabra, con la ambigüedad y el horror como características. Cesárea hablaba de "los tiempos que se avecinaban (...) allá por el año 2600. Dos mil seiscientos y pico" (Bolaño, 1998: 596) y dibujaba el plano de una fábrica de Santa Teresa, mientras que Auxilio vuelve a anclar el año en un espacio más explícito: un cementerio. ${ }^{183} 2666$ alude al año que materializa los enigmáticos vaticinios de Césarea o la imagen fúnebre de Auxilio pero juega también con las expectativas del género que ha puesto al futuro en primer plano. La radiografía del mal y la violencia que expone la novela está explícitamente anclada en el presente (en los últimos años que todavía son el presente) por lo que si el año 2666 refiere un futuro posible pareciera que no distará mucho del hoy, como si padeciera inexorablemente la repetición del pasado, acumulando ruinas, muertos, violencia. Es posible, entonces, evocar otra de las célebres alegorías de Benjamin para pensar cómo Bolaño figura los proceso históricos, como el ángel de la Tesis IX que es empujado "hacia el futuro (...) mientras que frente a él las ruinas se acumulan" (Benjamin en Löwy: 101). El mal y la violencia atraviesan tiempo (desde los griegos, según Kessler) y continentes, sea 1993 o 2666 "los arquetipos del crimen no cambian" (338) y la literatura puede ser tanto el camino hacia el horror como su propio antídoto.

"La parte de los crímenes" dialoga con la tesis del Profesor Kessler, experto en criminología, quien en el capítulo anterior, "La parte de Fate", teoriza sobre el mal cuya invención debemos a los griegos- y explica cómo la historia se ha encargado de acostumbrarnos al horror, cómo las grandes matanzas no alarmaron a nadie mientras que los crímenes particulares fueron "legibles" (339) para la sociedad en tanto las víctimas eran reconocibles, formaban parte de ella. En Santa Teresa nadie parece

\footnotetext{
${ }^{181} \mathrm{Si}$ vale la analogía de la escritura y la literatura con el montaje y las imágenes: "La imagen, no más que la historia, no resucita nada en absoluto. Pero redime: salva un saber, recita pese a todo, pese a lo poco que puede, la memoria de los tiempos" (Didi-Huberman, 2007: 256).

${ }^{182} \mathrm{La}$ idea es de Carlo Ginzburg citado por Didi-Huberman, sobre la necesidad "de aprender a leer los testimonios sosteniendo la tensión entre narración y documento" (2007).

183 "un cementerio del año 2666, un cementerio olvidado debajo de un párpado muerto o nonato" (Bolaño, 1999: 77)
} 
realmente comprometido ni espantado por las muertas -excepto quienes son enviados desde afuera para investigar (Fate, Rodriguez, Kessler)- ${ }^{184}$ por ello la lista de cadáveres se intercala con las historias que sí rompen con la rutina del pueblo, como la del Penitente que orina exageradamente en los atrios de las iglesias. El rol de los medios de comunicación partícipes del silenciamiento de los crímenes se exhibe en el espectáculo montado alrededor del profanador de iglesias. Por su parte, la diputada del PRI sólo se involucra para esclarecer la muerte de una amiga (cuya historia revela el ambiente denso de la política). Esta desidia ante los reiterados cuerpos que aparecen y no conmueven a nadie se manifiesta también en la actitud de la policía o los camilleros, que pueden hacer chistes machistas frente a las muertas (689) o pasar el parte por radio mientras piden tacos. ${ }^{185}$

Así, la sucesión de muertas se intercala con otras historias que parecen apartarse del foco inicial, pero aunque a veces distraen se vinculan complejamente para diseñar todas las aristas de Santa Teresa como topos del mal. "La parte de los crímenes" sondea la inserción social, laboral y cultural del mal. Santa Teresa se transforma así en el núcleo por donde convergen las formas de la violencia derivadas del narcotráfico, los conflictos de la frontera y la corrupción política, policial e industrial que promueven el crimen y la impunidad en los restos de una sociedad enferma, como los habitantes del basurero El Chile, muertos en vida.

La violencia de la historia se hace explícita en "La parte de Archimboldi" que transcurre mayormente en la Europa de la Segunda Guerra, y posguerra, se concentra en el nazismo y pone al día la tesis de Hannah Arendt acerca de la banalidad del mal. El escenario es la guerra en la frontera este ("principal escenario de sufrimientos", Arendt 2003: 125), del lado alemán la división de Hans Reiter combate de oeste a este, especialmente en Rumania, el avance soviético. Dada la derrota alemana, Reiter desiste seguir ocultándose en el bosque y se rinde ante soldados norteamericanos. En el campo de prisioneros conoce a Leo Sammer y su historia, un funcionario nazi que en una perdida aldea polaca administra el asesinato de casi quinientos judíos. El relato de Sammer conjuga la naturalización del mal con la constatación de cómo "lo horrible puede ser no sólo grotesco sino completamente cómico" (Arendt 2003: 34). El escenario

\footnotetext{
${ }^{184}$ Guadalupe Roncal confiesa a Fate: "Nadie presta atención a estos asesinatos, pero en ellos se esconde el secreto del mundo" (439)

185 ..."seis de carnita, tres con crema y tres sin crema, los seis bien picantes, y dos latas de Coca Cola" (533). Esta descripción trivial del menú del camillero contrasta con el paisaje donde el cadáver permanecería tres horas antes de que la policía llegara.
} 
es grotesco: una región gris con niños de diez años alcohólicos y adeptos al fútbol. Los niños polacos borrachos, tan sólo interesados en "partidos de fútbol etílicos" (956) serán los perpetradores de la masacre cuando ya no quede personal capaz de acatar las órdenes de Sammer. El principio de lo macabro sostiene también el discurso de Sammer, exageradamente burócratico, al punto de convertirlo en el "idiota moral" que Norbert Bilbeny (1993) define para describir a quien es incapaz de interpelar una orden, e irreflexivamente naturaliza el horror, con la apatía moral que evidencia el no utilizar su capacidad para distinguir el bien y del mal.

Sin embargo, Sammer sigue al pie de la letra la tesis de Arendt cuando revela la plena consciencia de sus actos y la necesidad de suavizarlos alegando ser sólo un pequeño engranaje, obedeciendo órdenes, cumpliendo debidamente con su trabajo. ${ }^{186} \mathrm{Su}$ relato insiste en las cuestiones administrativas que había que respetar ("me gustaría recibir esta orden por escrito, 949), nombra el asesinato como "operación", "tarea encomendada" (952) haciendo hincapié en el mecanismo y la organización que requieren cavar fosas en el bosque y disparar a poco menos de quinientas personas. El descaro final de su historia con el que apuesta al olvido y el perdón ${ }^{187}$ matiza el único acto de violencia consciente de Hans Reiter cuando decide estrangularlo (como confirmamos unas páginas más adelante). El sentimiento de culpa separa las consciencias de Sammer y Reiter. A diferencia del funcionario nazi, Reiter reconoce que el fantasma del asesino de judíos persigue su sombra, y para dejar de seguir “arrastrando la sombra infecta de Sammer" (972) será otro: cambiará de nombre y se volverá escritor.

\footnotetext{
${ }^{186}$ Casi que Sammer es la caricatura de Adolf Eichmann, utiliza los argumentos típicos de la defensa de criminales de lesa humanidad, sobre todo de aquello que antes que monstruos eran payasos (Arendt 2003, 37-39).

187 "Fui un administrador justo. Hice cosas buenas, guiado por mi carácter, y cosas malas, obligado por el azar de la guerra (...) Otro en mi lugar hubiera matado con sus propias manos a todos los judíos. Yo no lo hice. No está en mi carácter.” (959)
} 


\section{2. Desiertos de horror: América Latina, literatura y violencia}

Hasta aquí, algunos apuntes sobres las formas de la violencia que asedian la literatura y sus posibilidades de representación. Los vínculos que traman no solo permiten recuperar algo de la función social de la literatura, sus aportes para procesar acontecimientos históricos signados por la violencia y el trauma ${ }^{188}$ sino que también vuelven la mirada hacia los recorridos de la literatura misma en su especificidad. Pueden recuperarse, entonces, los diversos hilos que en la novela van tramando las imágenes de escritor que se rescatan así como la insistencia en varar las historias en el espacio latinoamericano.

La cultura y la literatura en América Latina están atravesadas por el impulso de la violencia que desde la Conquista ha fraguado relatos emanados de la apropiación y colonización del espacio latinoamericano. Octavio Paz condensa este origen violento, como marca identitaria del pueblo mexicano (extensible a todo el continente), a través de la figura de la Malinche, amante de Hernán Cortés, quien se fijó en el imaginario como traidora y Paz recupera a partir de la entrega y el ultraje poniendo el foco en la violación significada en la Conquista. ${ }^{189}$ La emergencia de los estados latinoamericanos y los comienzos de las literaturas nacionales también se constituyen desde el gesto violento de imponer, arrasar e invisibilizar al otro. David Viñas propone la violencia como punto de partida de toda una tradición literaria, por ejemplo, al instalar como escena inaugural de la narrativa argentina una "violación", las vejaciones que la

\footnotetext{
${ }^{188}$ Miguel Dalmaroni hace notar que "las reflexiones sobre problemas de memoria que toman las experiencias de la literatura y el arte suelen interrogar con especial énfasis los alcances que se conceden a nociones como las de resto, síntoma, trauma" (2009/2010): 10)

189 "¿qué es la Chingada? La Chingada es la Madre abierta, violada o burlada por la fuerza. El "hijo de la Chingada" es el engendro de la violación, del rapto o de la burla. Si se compara esta expresión con la española, "hijo de puta" se advierte inmediatarnente la diferencia. Para el español la deshonra consiste en ser hijo de una mujer que voluntariamente se entrega, una prostituta; para el mexicano, es ser fruto de una violación. (...) Si la Chingada es una representación de la Madre violada, no me parece forzado asociarla a la Conquista, que fue también una violación, no solamente en el sentido histórico, sino en la carne misma de las indias. El símbolo de la entrega es doña Malinche, la amante de Cortés. Es verdad que ella se da voluntariamente al Conquistador, pero éste, apenas deja de serle útil, la olvida, Doña Marina se ha convertido en una figura que representa a las indias, fascinadas, violadas o seducidas por 103 españoles. Y del, mismo modo que el niño no perdona a su madre que lo abandone para ir en busca de su padre, el pueblo mexicano no perdona su traición a la Malinche" (en El laberinto de la soledad).
} 
Mazorca rosista cometen contra el joven unitario en "El matadero" de Esteban Echeverría ${ }^{190}$

En las últimas décadas, la violencia ha despuntado diversas connotaciones, argumentos y relatos. En los sesenta/setenta, época fundamental para la historia política y cultural latinoamericana (Gilman 2002), tanto la izquierda, desde el mandato de la revolución, como la derecha, a partir de la Doctrina de la Seguridad Nacional fundamento de las dictaduras militares, han instituido como puntal la violencia con un sustento ideológico fuertemente manifiesto y polarizado.

Desde la izquierda, el intelectual revolucionario interpelado por Fidel Castro en las "Palabras a los intelectuales" (1961) adquiere también otra forma radical que será la del intelectual y escritor armado (Gatto 2004, Basile 2013) que recupera la violencia de foco como núcleo de su acción y de su poética. Como los "poetas combatientes" de Roque Dalton, casados con la Revolución, ${ }^{191}$ para quienes la violencia se figuraba como la "partera de la Historia" y "mamá del niño-pueblo". ${ }^{192}$ El imaginario de la violencia en los 60/70 incluye la figura del guerrillero héroe, cuyos valores (compañerismo, solidaridad, sacrificio) conjugan el carácter épico de la gesta revolucionaria con el elemento religioso que retoma no solo la idea de sacrificio sino de génesis en tanto la violencia constituye el acto fundacional de un nuevo orden. La estetización de la muerte, las imágenes del escritor-intelectual desde el compromiso a la lucha armada, los géneros literarios privilegiados para asumir las voces de la revolución, son marcas que la legitimación de la violencia imprime en los discursos literarios y culturales de la época.

\footnotetext{
${ }^{190}$ Ricardo Piglia agrega: "Se podría decir que la historia de la narrativa argentina empieza dos veces: en El matadero y en la primera página del Facundo. Doble origen, digamos, doble comienzo para una misma historia. De hecho los dos textos narran lo mismo y nuestra literatura se abre con una escena básica, una escena de violencia contada dos veces. La anécdota con la que Sarmiento empieza el Facundo y el relato de Echeverría son dos versiones (una triunfal, otra paranoica) de una confrontación que ha sido narrada de distinto modo a lo largo de nuestra literatura por lo menos hasta Borges. Porque en ese enfrentamiento se anudan significaciones diferentes que se centran, por supuesto, en la fórmula central acuñada por Sarmiento de la lucha entre la civilización y la barbarie" (en: La Argentina en pedazos. Ver también Alejandra Laera: "Para una historia de la literatura argentina: orígenes, repeticiones, revanchas", Prismas, Revista de historia intelectual, $\mathrm{N}^{\circ} 14,2010$, pp. 163-167, dic. 2010)

191 La figura es de Ernesto Cardenal, describiendo a Dalton.

192 Roque Dalton: "Sobre nuestra moral poética: No confundir, somos poetas que escribimos/ desde la clandestinidad en que vivimos./ No somos, pues, cómodos e impunes anonimistas:/de cara estamos contra el enemigo/ y cabalgamos muy cerca de él, en la misma pista. /Y al sistema y a los hombres / que atacamos desde nuestra poesía /con nuestra vida les damos la oportunidad de que se cobren, /día tras día."
} 
El ciclo de horror que se instala con las dictaduras ${ }^{193}$ abre nuevas aproximaciones a la violencia que desde las violaciones a los derechos humanos por parte de los estados promueve otros imaginarios, otras poéticas. La cuestión de la memoria se coloca en un espacio privilegiado de la agenda cultural para explorar los restos del pasado traumático desde diferentes aristas, como las víctimas o las derrotas. Desde la literatura, la pregunta por los modos de narrar el horror dará lugar a diferentes opciones estéticas para pensar las representaciones de la violencia. ${ }^{194}$ La posdictadura se asume entonces como un nuevo espacio de enunciación para el campo literario e intelectual atravesado por el impacto de las experiencias de las políticas de la violencia de Estado.

Los procesos democráticos, que en mayor o menor medida coinciden, de las décadas de los ochenta y noventa darán paso a nuevas coyunturas que son leídas desde los parámetros del neoliberalismo o la globalización. Así, para algunos las transiciones democráticas constituyeron el pasaje del "Estado moderno al mercado post-estatal" (Thayer, 1996), de la utopía al mercado (Avelar 2000) y la violencia se expande, sin ideologías ni consignas políticas, e impregna prácticas, discursos, saberes y relatos en tiempo presente. Las formas de la violencia traman diferentes niveles de complejidad que pueden resumirse en las tres categorizaciones propuestas por Slavoj Žižek (2009): la "violencia subjetiva" que es ejercida por sujetos reconocibles e identificables (como las formas del crimen), la "violencia sistémica o estructural", que ubicua y oculta, se enmascara en la red política y económica, y a diferencia de la primera resulta funcional al mantenimiento del orden de las cosas como normal o natural (es decir, no es desestabilizadora), y por último, la "violencia simbólica" que es la del lenguaje como tal y genera prácticas discursivas violentas (como las diferentes modalidades de discriminación). La violencia entonces se vuelve escritura, diseñando o visibilizando nuevas cartografías en el mapa cultural latinoamericano. Así, espacios que abren fronteras (en tanto territorio) a la conformación de nuevos imaginarios compartidos (como los sistemas político-económicos que no por democráticos, menos violentos)

193 La fecha simbólica de inicio de uno de los períodos más oscuros de América Latina, 11 de septiembre de 1973, excluye otros procesos dictatoriales pues se circunscribe al Cono Sur (ver Gilman, Beverley, Avelar)

194 La experiencia latinoamericana puede leerse a luz de otros nudos traumáticos de la historia occidental. Así, diferentes perspectivas se nutren de los debates que en otras regiones surgieron a partir sobre todo del nazismo. Como las posibilidades del testimonio (Levi, Agamben), o las (im)posibilidades de la representación (Adorno), la cuestión del mal, las culpas y complicidades (Arendt), el trauma (Felman, LaCapra), entre otros temas. 
trazarán los nuevos contornos de la literatura latinoamericana, bajo el prisma de la globalización y el neoliberalismo.

La profundización del modelo neoliberal y globalizador que desde la década del noventa ha transformado la arena social y política latinoamericana configuró un espectro de conceptos y categorías de análisis que desde las ciencias sociales o la crítica cultural focalizan en las alteraciones violentas experimentadas en diversos órdenes: inflación, privatización, desregulación, precarización, exclusión, empobrecimiento, marginalización, fragmentación. Los diversos ejes incluyen el rol del Estado respecto del bienestar público, el mercado laboral, las nuevas configuraciones del espacio urbano y las subjetividades (Borón, Minsburg, Ferrer, 1999). Los cambios no son ajenos a las visiones y representaciones del presente que la narrativa latinoamericana procesa e incorpora en mayor o menor grado, oblícua o explícitamente.

En 2666 se afianzan todas las imágenes que conforman el cuadro general de la representación del abismo en que se ha convertido -en la propia obra de Bolaño- eso llamado "América Latina". La violencia de las dictaduras militares, los desaciertos de la lucha revolucionaria y la derrota de la utopía configuran un complejo núcleo que genera y trastorna el Hipertexto-Bolaño. Pero Bolaño no se detiene allí, también se ocupa de la violencia del presente instalada en el escenario neoliberal que disfraza el horror con los harapos del progreso.

Es allí, en Santa Teresa, donde los ecos fúnebres del desierto de Juan Rulfo encarnan en un paisaje recorrido por los pasos perdidos de los personajes, cuyo rasgo esencial es la presencia de cadáveres. Es decir, la ciudad no está habitada por espectros, la ciudad está repleta de cuerpos torturados, vejados y mutilados. Exploraremos ahora los modos en que la violencia (y sus derivas -el crimen, el mal) se instala como eje omnipresente no sólo en la representación de América Latina sino también, desde su tradición literaria, en las posibilidades de la literatura misma.

Durante los sesenta-setenta, la revolución cubana apareció como un centro de entusiasmo y utopía que arma un mapa latinoamericano y europeo (podemos mencionar a Sartre para ilustrar las adhesiones provocadas en Europa) tal como estudia Iván de la Nuez en Fantasía roja (2006). ${ }^{195}$ En cambio en los noventa, el mapa que arma Bolaño no tiene que ver con el frenesí revolucionario que conectó América con Europa sino con

\footnotetext{
${ }^{195}$ Y se ilustra en la tapa de la primera edición, donde se ve a Ernesto Che Guevara sentado frente a Jean Paul Sartre, como si conversaran. El juego de perspectiva de la imagen hace que la figura del Che sea significativamente superior a la del filósofo francés.
} 
las escenas de barbarie y horror que instalaron las guerras, las dictaduras, los totalitarismos.

Aquella imagen idílica, mágica y maravillosa de América Latina que se articuló a partir de la revolución cubana y que posteriormente se convirtió en una imagen estereotipada y vacía que algunos perciben en el "macondismo" se quiebra en Santa Teresa, esta ciudad latinoamericana donde, como en su precursora Comala, lo único que fluye es la violencia. Cuando José Joaquín Brunner define el "macondismo" como un constructo que intenta plasmar una supuesta superioridad latinoamericana, una identidad exclusiva fraguada a partir de ciertos conceptos como naturaleza, exotismo o misterio no está apuntando contra la obra de García Márquez sino contra su posterior recepción. Tal es la línea que recupera Emil Volek cuando distingue una versión "posmoderna, facilona y degradada" del realismo mágico de lo que en verdad se desprende de las obras de Asturias, Carpentier, Arguedas, o Rulfo cuya estética revolucionaria abrió nuevos espacios a realidades antes marginadas. No es legítimo simplificar el potencial estético y crítico de los escritores del boom ni reducirlos apelando a un concepto posterior como el llamado "macondismo".

Es en esta línea que Bolaño fractura el optimismo identitario en su versión más simplista y estereotipada, y descarta sus herederos más abyectos: "sus hijos tarados" para decirlo con las palabras del mismo Bolaño en "Los mitos de Chtulhu” (2003: 173). Si Brunner asevera que se ve a América Latina como "el nuevo mundo desde donde surgirá una 'racionalidad alternativa' para Occidente" Bolaño nos propone que esa racionalidad camina junto a la barbarie y que no es alternativa pues ya es universal. Así, la respuesta de Bolaño a estos conceptos identitarios estancos no puede ser sino estética, es decir para discutir el "macondismo" Bolaño requiere de la literatura y recupera a Macondo via Comala ${ }^{196}$ y funda Santa Teresa.

La ciudad hilvana las cinco partes que conforman 2666, y desde la primera vez que se la menciona percibimos, los lectores de Bolaño, que nada bueno puede suceder en ella. En "La parte de los críticos" cuando los académicos europeos conocen a Amalfitano (el profesor experto en Benno von Archimboldi) la primera impresión fue "mala (...) perfectamente acorde con la mediocridad del lugar" (152). Amalfitano parece "un tipo fracasado", "un tipo muy triste" (153)-como el tono de toda la segunda parte dedicada a este profesor sudamericano exiliado en Europa, padre viudo, que ve

\footnotetext{
${ }^{196}$ En una genealogía que incluye a Santa María de Onetti, El Olivo de Donoso, Santa Mónica de los Venados de Carpentier.
} 
sombras y escucha voces y no sabe qué ha venido a hacer a Santa Teresa. Luego del encuentro con Amalfitano los críticos tienen pesadillas: Pelletier sueña con sangre y mierda, Espinoza con un cuadro en el desierto en el que "las palabras se abrían paso a través del aire enrarecido del cuadro como raíces víricas en medio de carne muerta" (154). Norton se ve en sus sueños inmóvil, inerte en la figura de una mujer, "es igual a mí, se dice, pero ella está muerta" (155).

En "La parte de Fate" la sensación que persigue al periodista estadounidense es la de irrealidad. Fate está acostumbrado a tratar con personajes fantasmales, los entrevistados de sus notas de "pintoresquismo sociológico" (332). Rumbo a Santa Teresa, en un restaurant en medio del desierto, Fate escucha desde su mesa la conversación entre un tipo joven y un tipo canoso quien esboza una especie de tratado sobre el mal, sobre su ocultamiento y a la vez su presencia, sobre cómo las sociedades se regodean con la espectacularidad del mal, sobre las relaciones entre injusticia y marginalidad. El tipo canoso es Albert Kessler, el experto criminólogo, quien respecto de Santa Teresa sentencia "lo mejor que podrían hacer es salir una noche al desierto y cruzar la frontera, todos sin excepción, todos" (339). A partir de entonces Fate manifestará constantes signos de enfermedad, náuseas, vómitos. Sin embargo, cuando termina su trabajo de cronista deportivo (sobre una pelea de boxeo) en lugar de regresar a Nueva York "donde todo volvería a tener la consistencia de la realidad" (396) decide permanecer en Santa Teresa atraído por el misterio de los crímenes y por la vida nocturna que revela historias de narcos, prostitución y muerte.

Si en el artículo sobre la literatura latinoamericana de los noventa ("Los mitos de Chtulhu”), que anteriormente mencionamos, Bolaño vislumbraba un destino apocalíptico “(...) allí mero donde se aburre una osamenta, se puede divisar Comala, la ciudad de la muerte. Hacia esa ciudad se dirige montado en un asno este discurso magistral y hacia esa ciudad me dirijo yo y todos ustedes, de una manera o de otra, con mayor o menor alevosía” (167). En 2666 redobla la apuesta y nos conduce a Santa Teresa, ese territorio crepuscular donde nunca llueve -a diferencia de Macondo y Comala. En esta ciudad, en medio del desierto, las únicas imágenes asociadas al agua tienen que ver con la muerte. En "La parte de los crímenes" se materializa lo que se viene anunciando: "En marzo no apareció ninguna muerta en la ciudad, pero en abril aparecieron dos, con escasos días de diferencia, y también las primeras críticas a la actuación policial, incapaz no sólo de detener la ola (o el goteo incesante) de crímenes sexuales" (565, énfasis nuestro). Esta imagen de "goteo incesante" es reiterada varias 
veces para describir "todas las muertas que literalmente brotaban del desierto de Santa Teresa" (701). El mal es el río que recorre las tierras fronterizas del desierto mexicano, que podría ser cualquier otro desierto. El mal, por supuesto, no es exclusivamente latinoamericano sino occidental, pero el centro gravitatorio está siempre en América Latina, y si la escritura que lo indague hará estallar la literatura y la historia latinoamericanas es para desde allí refractar -y detonar- hacia otras tradiciones, otras Historias.

Bolaño opera en el interior de la literatura latinoamericana más canonizada, la del boom, para quebrantar todo mito de totalidad asociado a una posible identidad continental de tintes optimistas, contra toda imagen que estanque la esencia exclusiva de lo latinoamericano como una identidad otra, fabulosa, exótica. Su narrativa desplaza ese realismo mágico anclado en el mundonovismo que intentaba explorar la naturaleza desbordante y la religiosidad americana hacia los territorios desolados de las dictaduras y la pérdida de la utopía, para articular una escritura visceral, sin épica, cuyo paisaje emblemático es el desierto. Este espacio simbólico tan utilizado en diferentes épocas y discursos que ha generado imaginarios, promovido preocupaciones políticas y culturales aparece en la novela resignificando la antinomia civilización y barbarie. Ambos conceptos se retroalimentan en Santa Teresa donde el desierto no es solo el espacio de lo bárbaro sino que alberga precisamente los despojos, los restos de la civilización. El desierto ha sido representado como escollo del progreso y, desde Domingo $\mathrm{F}$. Sarmiento, constituyó un sistema cuya dialéctica de excesos y limitaciones atentaba contra el avance civilizatorio; ${ }^{197}$ además de ser el espacio de los primeros genocidios en el sur de América que tienen su punto culminante con las Campañas al Desierto impulsadas por Julio A. Roca (1878-79). Bolaño rearma el mapa de la civilización y la barbarie en Santa Teresa. El escenario de los feminicidios presenta la pujanza de la industria y el progreso económico que, sin embargo, se enmarcan en lo que Sergio González Rodríguez describe como "exceso de desierto" (2002: 25) y ese desborde llama la atención sobre el "impulso de normalizar la barbarie en las sociedades contemporáneas” (González Rodríguez 2002: 12).

El escenario de la violencia entonces está configurado a partir del juego siniestro entre horror y progreso (modernización, industria, trabajo, etc.) y está representado por

${ }^{197}$ Ver al respecto: Fermín Rodríguez, "Sarmiento en el desierto. Exceso de vida, instinto de muerte" (2002). 
las maquiladoras de la frontera mexicana con Estados Unidos. ${ }^{198}$ Estas fábricas tercerizadas donde las mujeres acuden con vistas a mejorar y, si lo consiguen, intentar el cruce de la frontera hacia otra promesa de progreso resumen las diversas formas en que la violencia neoliberal corroe y aniquila todo. Las víctimas de Ciudad Juárez se constituyen en el ejemplo atroz de los efectos que han reconfigurado el clásico par civilización y barbarie, y como señala Rita Segato la "frontera entre la miseria-delexceso y la miseria-de-la-falta es un abismo". Si bien hay relatos conformados en torno a algunas hipótesis sobre los asesinatos (sobre todo a partir del narcotráfico) ${ }^{199}$ no es posible acceder a su núcleo central, a aquello que mueve los hilos del horror, cuando la violencia “es la vida misma” (Del Sarto 2012: 43). Esta imposibilidad, este nudo que se escapa es lo que Bolaño recupera en la versión descomunal que presenta en Santa Teresa y que hace sistema con los horrores de la historia que todo el Hipertexto-Bolaño pasa por el proceso inventivo de su literatura.

Si una de las obsesiones de Bolaño reside en las muertes de la historia reciente latinoamericana, vemos especialmente en esta novela póstuma que se detiene en los nudos incómodos de la historia (aquí está el nazismo también) sin anquilosar su pulsión narrativa que siempre va más allá, o sea siempre está en movimiento. Aquí también está la historia del presente (la frontera, el narcotráfico, el crimen social, etc.) y está también una tradición literaria que ha tratado de dar cuenta de procesos histórico-culturales. E1 tamiz perceptivo de lo real es la literatura, por eso para articular "la oscura raíz del mal" anclado en occidente -que es lo mismo que decir Chile, México, la intemperie latinoamericana o la Europa "amnésica, sin épica ni heroísmo" (Bolaño, 2010) - se conjuran las formas que la literatura ofrece. Si se interpela toda una biblioteca babélica, borgeana- primero se desempolvan las hojas estancas de la tradición latinoamericana para incorporar lo latinoamericano al resto del mundo prescindiendo de

\footnotetext{
198 Rita Segato inicia su excelente estudio sobre los femicidios mexicanos con esta apreciación significativa: "Ciudad Juárez es también, significativamente, un lugar emblemático de la globalización económica y del neo-liberalismo, con su hambre insaciable de ganancia. La sombra siniestra que cubre la ciudad y el miedo constante que sentí durante cada día y cada noche de la semana que allí estuve me acompañan hasta hoy, más de un mes después de mi regreso al Brasil” (Segato 2006).

${ }^{199}$ Es interesante la visión de Segato al respecto: “(...)autoridades y formadores de opinión, aunque pretenden hablar en nombre de la ley y los derechos, estimulan una percepción indiscriminada de la cantidad de crímenes misóginos que ocurren en esta localidad como en cualquier otra de México, de Centroamérica y del mundo: crímenes pasionales, violencia doméstica, abuso sexual, violaciones a manos de agresores seriales, crímenes por deudas de tráfico, tráfico de mujeres, crímenes de pornografía virtual, tráfico de órganos, etc. Entiendo esa voluntad de indistinción, así como también la permisividad y naturalidad con que en Ciudad Juárez se perciben todos los crímenes contra las mujeres, como un smokescreen, una cortina de humo cuya consecuencia es impedir ver claro un núcleo central que presenta características particulares y semejantes" (Segato 2006).
} 
esencias identitarias. Situar a Bolaño en el marco de una nueva literatura mundial, sin que esto se reduzca a plantear una cultura occidental homogénea, no implica descartar la importancia de de una tradición latinoamericana que se constituye en punto de partida, en el grado cero al que Bolaño regresa insistentemente. Aunque en Bolaño no hay "el retorno a la patria", ${ }^{200}$ sino por el contrario hay un viaje constante, idas y venidas que hilvanan una trama universal que si tiene un destino al que regresar éste es siempre la literatura. Por eso 2666 termina (no cierra) con "La parte de Archimboldi", donde los lectores (no los académicos europeos de la primera parte) encontramos a Benno von Archimboldi, el escritor gigante, el escritor alga que explora las profundidades del mar y los abismos de la tierra.

La figura de escritor que Archimblodi encarna en imágenes signadas por diversos atributos que recuperan motivos ya presentes en todo el Hipertexto-Bolaño. Lo defectuoso o fuera de lo común aparece en las diferentes imágenes de mutilación ya desde la primera parte con Morini en sillas de ruedas o la amputación del pintor Edwin Jones, Archimboldi es hijo de una coja y un tuerto. La locura o la enfermedad caracterizan a Lola, al poeta en Mondragón, la residencia de escritores desaparecidos que no es más que un manicomio o también la débil salud de Ingerborg y las vestiduras de loco que el uniforme de soldado de Reiter esconde como Parcifal. Otro rasgo que define a Archimboldi será lo salvaje y lo oculto, desde su niñez en la pequeña aldea donde pasaba horas lejos de su casa buceando o leyendo hasta su vida de escritor consagrado pero ajeno a los circuitos literarios (no se conocen más que sus obras). Se inicia en la lectura a los seis años cuando roba un libro (sobre animales y plantas, 799); tiene problemas con la lengua desde pequeño, habla con dificultad, luego durante la guerra pierde la voz y la recupera luego de leer el cuaderno de Ansky y soñar la muerte del judío de Kostekino. Finalmente se convierte en escritor, como si toda su vida hubiese ensayado la palabra hasta encontrar su rumbo. Ansky, escritor judío, soldado comunista perseguido por Stalin, por Hitler, por la sombra de una existencia ignota en el mundo literario, es su modelo e inspiración. La lectura del cuaderno de Ansky, desconocido como verdadero autor de las obras del famoso Ivanov (quien representa al escritor vinculado al estado, a las instituciones que Archimboldi rechazará), terminará

\footnotetext{
${ }^{200}$ Raúl Rodriguez Freire señala a propósito de Los detectives salvajes: "Los viajes de Ulises y Arturo (...), pueden ser leídos como la más radical deconstrucción (que no la simple inversión) del amor a Ítaca, como la narración del agotamiento de aquella política de filiación que vinculaba hasta la muerte (y, en algunos textos, incluso más allá de ella) tierra y destino, patria y vida. Se trata de una ruptura con la economía del retorno".
} 
de fraguar su vocación. De hecho, la mirada de Reiter ya no será la misma. Los días en su escondite del bosque terminan cuando finaliza la lectura de las anotaciones de Ansky y las percepciones respecto de la guerra se tornarán oscuramente metafóricas, como si la visión de Reiter ya fuese la de un escritor, como si la guerra lo afectara por primera vez. Así, los soldados que quedaban de su división "parecían locos huidos del manicomio" (924), una columna de tanques parecen "ataúdes de una civilización extraterrestre" (925), y se resumen los horrores de la guerra en las historias del general Entrescu y Leo Sammer.

Cuando Hans Reiter conoce estos abismos se convierte en escritor, cambia su nombre a Benno von Archimboldi y sólo le interesa escribir. Su vida de Hans Reiter nos ubica en la Alemania de guerras y posguerras, en aldeas con habitantes austeros y trabajadores, en las relaciones de aristócratas y generales, en el corazón de Europa. Sin embargo, en medio de este relato se abre la grieta que nos lleva otra vez a Santa Teresa. Primero cuando conoce a Ingerborg, luego su esposa, quien le cuenta sus teorías sobre los aztecas, con "sus pirámides teñidas de rojo con la sangre de la gente sacrificada cada día" (871), luego cuando Archimboldi sorpresivamente explica que el nombre Benno es una referencia a Benito Juárez (y no a Mussolini como hubiera parecido sospechoso, aunque lógico, para el editor Bubis). También, cuando al pasar conocemos que las pinturas perdidas de Halder son cuadros de mujeres, todas muertas (853), o el desierto mexicano repleto de cadáveres resuena en las tierras abarrotadas de huesos de la Europa de posguerra y finalmente cuando nos enteramos que el preso de Santa Teresa, Haas, es su sobrino, el hijo de Lotte, la hermana que tanto adoró Reiter. Y es un ida y vuelta si recordamos las lecturas de Amalfitano sobre el origen griego de la lengua mapuche. $\mathrm{O}$ si notamos la caracterización de un poeta soviético en la Universidad de Moscú, “tan inconsciente $\mathrm{y}$ necio $\mathrm{y}$ remilgado $\mathrm{y}$ timorato $\mathrm{y}$ melindroso como un poeta lírico mexicano" (908).

Se forma así el círculo perfecto, e infinito, que traza la narrativa de Bolaño. Si nos adentramos por los pasillos y residuos de la academia (en la primera parte) hacia los bajofondos del horror (en las tres partes que siguen), en el final -"La parte de Archimboldi"- se vislumbra una salida, porque es la parte donde prevalece la literatura: es una historia de amor, es la vida de un escritor (no la de sus críticos fanáticos y vacíos) y de su concepción de la literatura, reñida con la fama, en constante proliferación. (Las últimas palabras de la novela son "se marchó a México" (1119)). Y si coincidimos con Magda Sepúlveda cuando analiza las sub-versiones genéricas en 
2666 (el policial, la novela romántica, el gótico) y sugiere que Bolaño vuelve "a la literatura contra la literatura" (2011: 241), es porque la literatura es la clave del mundo Bolaño; es la literatura que mete la cabeza en el abismo, la que pende de una cuerda a la intemperie. 


\section{CODA}

La propuesta de lectura de la narrativa completa de Roberto Bolaño que hemos planteado ha recuperado la figura de escritor latinoamericano que muchas veces la crítica desestima al suponer un anclaje en el estereotipo de la generación del boom como último constructo identitario de América Latina al mundo (olvidando el potencial crítico e innovador que tuvo). En ocasiones, esta lectura simplifica los alcances de pensar a Bolaño como "autor latinoamericano" y ha recolocado el éxito de su obra como un "efecto del mercado". Pensar en América Latina como locus de enunciación de Bolaño no implica localizarlo ni encerrarlo en las fronteras simplistas del exotismo (como algunos ven en la recepción europea y anglosajona de su obra). Al mismo tiempo, situar a Bolaño en los desplazamientos y torsiones que la literatura latinoamericana realiza desde los años sesenta/setenta a los noventa atendiendo a la fuerte impronta que la coyuntura histórica de la región tuvo no le cierra las puertas de la denominada nueva literatura mundial, que ha sido recientemente centro de debates (Sánchez-Prado, Corral, Echeverría).

El horizonte desolador que dejaron las últimas dictaduras en el continente es telón de fondo en todo el Hipertexto-Bolaño. Hemos visto cómo el relato del trauma organiza e integra cada texto a través de diferentes operaciones que complejizan una obra difícil y por momentos hermética. Los tópicos de la "juventud castrada/sacrificada", del "sobreviviente", del "melancólico", entre otros articulan una trama complicada en la cual literatura y vida se vuelven inseparables. Esto mismo se presenta a través de una "escritura del trauma" y de un "trauma de la escritura" que aparecen somatizados en el relato a través de las torsiones y los desplazamientos que Bolaño realiza a las formas y a los géneros literarios (policial, fantástico, testimonio, etc.). Este núcleo traumático adquiere diversas inscripciones y figuras tales como lo siniestro/ominoso o el vacío en la metáfora de "la pista de hielo". La fuerte apuesta a la ficción fragua una escritura atenta a una enorme biblioteca "extraterritorial" (en la huella de Borges) con la cual dialoga (utilizamos la categoría que Ignacio Echeverría emplea cuando lee a Bolaño y que a su vez recupera del concepto que George Steiner usa al definir a todo escritor como un turista infatigable, con una escritura en exilio permanente). 
De allí que muchos vinculen los diferentes textos de Bolaño con un amplio corpus de escritores (tales como los lazos con la cuentística estadounidense de los ochenta señalados por Marcelo Cohen, y con las grandes narrativas de Mark Twain o Herman Melville, o con la pulsión kafkiana que los lúcidos trabajos de Ilse Logie desentrañan; y seguramente Matadero Cinco de Kurt Vonnegut abra otros umbrales a la lectura de 2666). En fin: como reconoce Echeverría, el "mapa de las devociones literarias" de Bolaño como entrada a sus textos impone una tarea al menos difícil sino imposible. En este trabajo hemos preferido recuperar ciertas zonas de la tradición literaria latinoamericana en las que Bolaño ingresa de manera arrolladora para configurar una escritura nada sencilla sobre América Latina, que recala en los nudos más terribles de su época: que remite a 1973, a 1990, y tal vez también a 2600 y pico. 


\section{BIBLIOGRAFÍA}

\section{De Roberto Bolaño:}

Consejos de un discípulo de Morrison a un fanático de Joyce, Rubí (Barcelona), Anthropos, 1984. En colaboración con Antonio García Porta.

La literatura nazi en América, Barcelona, Seix Barral, 1996.

Estrella distante, Barcelona, Anagrama, 1996

Llamadas telefónicas, Barcelona, Anagrama, 1997.

Los detectives salvajes, Barcelona, Anagrama, 1998.

Monsieur Pain, Barcelona, Anagrama, 1999. (1994, La senda de los elefantes, Ayuntamiento de Toledo)

Amuleto, Barcelona, Anagrama, 1999.

Nocturno de Chile, Barcelona, Anagrama, 2000.

Putas asesinas, Barcelona, Anagrama, 2001.

Amberes, Barcelona, Anagrama, 2002.

Una novelita lumpen, Barcelona, Mondadori, 2002.

La pista de hielo, Barcelona, Seix Barral, 2003. (1993, Alcalá de Henares)

El gaucho insufrible, Barcelona, Anagrama, 2003.

2666, Barcelona, Anagrama, 2004.

Entre paréntesis, Barcelona, Anagrama, 2005.

Bolaño por sí mismo, Entrevistas escogidas, Andrés Braithwaite (editor), Santiago, UDP, 2006.

El secreto del mal, Barcelona, Anagrama, 2007.

Los perros románticos y Tres, Montevideo, El Faro, 2008.

Los sinsabores del verdadero policía, Barcelona, Anagrama, 2011. 


\section{Sobre Roberto Bolaño:}

Aguilar Paula, "Literatura y melancolía en el contexto de la posdictadura chilena", en Edmundo Paz Soldán, y Gustavo Faberón Patriau (Eds.) Bolaño salvaje, Barcelona, Candaya, 2008.

Aguilar Paula, "Violencia y literatura. Acerca de cómo conjurar el pasado traumático latinoamericano", Alpha. Revista de Artes, Letras y Filosofía, Universidad de Los Lagos, Osorno, Chile, n 30, julio, 2010.

Aguilar, Gonzalo, "Roberto Bolaño, entre la historia y la melancolía" en Celina Manzoni (compilación, prólogo y edición), Roberto Bolaño. La escritura como tauromaquia, Bs. As., Corregidor, 2002, 145-151.

Aguilar, Gonzalo. "Los amuletos salvajes de un novelista" Suplemento Cultura y Nación, Clarín, Buenos Aires, 25 de marzo de 2001.

Almonte, Carlos "Acerca de Roberto Bolaño y su aporte a la narrativa chilena actual”, Universidad de Chile. Julio de 2005

Andrews, Chris ““Algo va a pasar': los cuentos de Roberto Bolaño”. Roberto Bolaño una literatura infinita. Coord. Fernando Moreno. Poitiers, Université de Poitiers, 2003, $33-40$.

Andrews, Chris, "Roberto Bolaño: elegía y alegría" en Revista Mensaje $\mathrm{N}^{\circ} 494$, Noviembre de 2003, en línea: http://www.letras.s5.com/rb100706.htm (12 ago 2009).

Areco Morales, Macarena Luz, "Los detectives salvajes de Roberto Bolaño y el juicio a la vanguardia", Anales de Literatura Chilena, 8:8, Dic 2007, 185-197.

Aspurúa Javier "Melancólicos a la intemperie", en Las Ultimas Noticias. 24 de octubre de 2001

Bisama, Álvaro "Cut \& Paste", en "Bolaño inmortal" Lanzallamas fanzine especial, en línea: www.lanzallamas.org/belano/21.html, 2008. (3 abr 2012).

Bolognese, Chiara, "Roberto Bolaño y Raúl Zurita: referencias cruzadas", Anales de literatura chilena, Año 11, Diciembre 2010, Número 14, 259-272.

Bolognese, Chiara, Pistas de un naufragio, Córdoba, Alción, 2010.

Burgos, Carlos, "Roberto Bolaño, la violencia, el mal, la memoria”, Nuevo texto crítico, vol 22, n 42-43, 123-144.

Candia, Alexis, “2666: La magia y el mal”, Taller de letras, n 38, 2006, 121-139. 
Candia, Alexis, "Todos los males el mal. La "estética de la aniquilación" en la narrativa de Roberto Bolaño", Revista Chilena de Literatura, n 76, Abril 2010, 43-70.

Candia, Alexis, "Tres: Arturo Belano, Santa Teresa y Sión. Palimpsesto total en la obra de Roberto Bolaño", Espéculo. Revista de estudios literarios. Universidad Complutense de Madrid. 2005Disponible en: http://www.ucm.es/info/especulo/numero31, (3 abr 2011).

Cánovas, Rodrigo, "Fichando "La parte de los crímenes" de Roberto Bolaño, incluida en su libro póstumo 2666", Anales de literatura chilena, año 10, junio, número 11, 2009, 241-249.

Casas, Fabián. "Simpatía por el demonio. Sobre El Tercer Reich de Roberto Bolaño", Perfil, domingo 02 de mayo, 2010, en línea: www.perfil.com.

Cobas Carral, Andrea ""Déjenlo todo nuevamente": Apuntes sobre el Movimiento Infrarrealista Mexicano", Universidad de Buenos Aires, 2005, en www.letras.s5.com.

Cobas Carral, Andrea y Verónica Garibotto, "Un epitafio en el desierto. Poesía y revolución en Los detectives salvajes." Bolaño salvaje. Eds. Edmundo Paz Soldán y Gustavo Faverón Patriau, Barcelona, Candaya, 2008. 43-58.

Corral, Wilfrido, Bolaño traducido. Nueva literatura mundial. Madrid, Escalera, 2011.

De Rosso, Ezequiel. “Una lectura conjetural. Roberto Bolaño y el relato policial”, en Manzoni, Celina ed. Roberto Bolaño. La escritura como tauromaquia, Buenos Aires, Corregidor, 2002.

Echevarría, Ignacio, "Bolaño internacional. Algunas reflexiones en torno al éxito internacional de Roberto Bolaño”, Estudios Públicos, 130, otoño 2013, 175-202.

Echeverría, Ignacio (1996) "Historia particular de una infamia” y (2002) "Bolaño extraterritorial" en Desvios, un recorrido crítico por la reciente narrativa latinoamericana, Universidad Diego Portales, Santiago, 2007.

Epple, Juan Armando, "El Nazismo en Chile, a propósito de un libro polémico" Pluvial, Revista de Literatura y humanidades: 86-93, 2000.

Espinosa Patricia “Roberto Bolaño, un umbral”, Revista Universitaria, No 89. Dic- Mar. 2006.

Espinosa Patricia "Vericuetos de una conciencia tenebrosa", Rocinante, marzo de 2001. Espinosa Patricia, "Bolaño y el manifiesto infrarrealista", Rocinante $\mathrm{N}^{\mathrm{o}} 84$, Octubre 2005.

Espinosa, Patricia (comp.), Territorios en fuga. Estudios críticos sobre la obra de Roberto Bolaño, Frasis, Santiago de Chile, 2003. 
Espinosa, Patricia. "Introducción: Entre el silencio y la estridencia.” Territorios en fuga: Estudios críticos sobre la obra de Roberto Bolaño. Santiago, Frasis, 2003. 13-32. Espinosa, Patricia. "Roberto Bolaño: un territorio por armar" en Celina Manzoni editora. Roberto Bolaño: la escritura como tauromaquia, Buenos Aires, Corregidor, 2002.

Faverón Patrieu, Gustavo, "El rehacedor: 'El gaucho insufrible' y el ingreso de Bolaño en la tradición argentina”. En: Paz Soldán, Edmundo y Faverón Patriau, Gustavo (eds.): Bolaño Salvaje. Barcelona, Candaya, 2008, 371-415.

Figueroa, Julio Sebastián, "Exilio interior y subjetividad pos-estatal: "El gaucho insufrible" de Roberto Bolaño", Revista Chilena de Literatura, Abril 2008, n. 72, 149 161.

Fresán, Rodrigo “The Savage Detective: The Only Protagonist of Roberto Bolaño's Work-the Authentic Heroine of His Books-Is Literature Itself”, Believer, vol. 5, no. 2, Mar 2007, 3-14.

Fresán, Rodrigo, "Pequeño Big Bang”, Página 12, 27 de julio, 2003 (en línea www.letras.s5.com)

Fresán, Rodrigo, "Volver al 79”, Radar Libros -Página 12, 13 de octubre 2002.

Gamboa Cárdenas, Jeremías. “¿Siameses o dobles? Vanguardia y Postmodernismo en Estrella distante de Roberto Bolaño". Bolaño salvaje. Edmundo Paz Soldán y Gustavo Faverón Patriau Eds. Barcelona, Candaya, 2008, 163-89

Gigena, María Martha "La negra boca de un florero: metáfora y memoria en Amuleto", en Manzoni (ed), 2003, 17-32.

González, Daniuska, La escritura bárbara: la narrativa de Roberto Bolaño, Lima: Fondo Editorial Cultura Peruana, 2010.

Gras Miravet Dunia "Entrevista con Roberto Bolaño", Cuadernos hispanoamericanos, Madrid, Ediciones Cultura Hispánica, n. 604 (octubre 2000), 53-65

Huneeus, Marcial, “¿De qué hablamos cuando hablamos del mal? 2666 de Roberto Bolaño", Roberto Bolaño. La experiencia del abismo, Fernando Moreno coord., Santiago: Ed. Lastarria, 2011, 253-268.

Jennerjahn, Ina, "Escritos en el cielo y fotografías del infierno. Las "acciones de arte" de Carlos Ramírez Hoffman según Roberto Bolaño", Revista de crítica literaria latinoamericana, año XXVIII, n 56, Lima-Hannover, 2 semestre 2002, 69-86.

Kohan Silvia Adela "Entre el juego y el olvido", Entrevista con Roberto Boalño, La Nación (Buenos Aires), Barcelona, 25/04/01. 
Logie. Ilse, "Roberto Bolaño y el mal: análisis de "El policía de las ratas"”, Lieux et figures de la barbarie, CECILLE-EA, Univ. De Lille 3, 2006-2008.

Lopez Vicuña, Ignacio, "Malestar en la literatura: Escritura y barbarie en Estrella distante $\mathrm{y}$

Lucero Bustos Ana Karina, "Novelita, Lumpen, Testimonio: Coordenadas y variables de un ejercicio", La santísima trinidad de las cuatro esquinas, jueves, 30 de mayo de 2013.

Madariaga Caro, Montserrat, Bolaño infra. 1975-1977, los años que inspiraron Los detectives salvajes, Santiago, RIL editores, 2010.

Magnet, Alberto “Las patrias de Roberto Bolaño”, El Mostrador, 21 de Enero del 2005.

Manzi, Joaquin, "Mirando caer otra Estrella Distante”, Caravelle 82, Toulouse, 2004, 125-141.

Manzoni, Celina (comp.), Roberto Bolaño. La escritura como tauromaquia, Buenos Aires, Corregidor, 2002.

Manzoni, Celina "Biografías mínimas/ínfimas y el equívoco del mal". En: Manzoni (ed.), 2002: 17-32.

Manzoni, Celina "Recorridos urbanos, fantasmagoría y espejismo en Amuleto", en Manzoni, Celina (ed.) La fugitiva contemporaneidad. Narrativa latinoamericana 19902000, Buenos Aires, Corregidor, 2003, 33-52.

Manzoni, Celina, "Reescritura como desplazamiento y anagnórisis en Amuleto de Roberto Bolaño", en: Hispamérica 94, 2003b, 25-32.

Moreno, Fernando "Los laberintos narrativos de Roberto Bolaño", en Moreno, Fernando (coord), Roberto Bolaño: la experiencia del abismo, Santiago, Lastarria, 2011, 333-344.

Nocturno de Chile de Roberto Bolaño", Revista Chilena de Literatura, vol. 75, Nov 2009, 199-215.

Paz Soldán, Edmundo, "Roberto Bolaño: Literatura y apocalipsis”. En: Paz Soldán, Edmundo y Faverón Patriau, Gustavo (eds.), Bolaño salvaje. Barcelona, Candaya, 2008.

Pino Mirian, "Roberto Bolaño y las relecturas de la novela negra: La pista de hielo", Literatura y Lingüistica, n 17, Santiago, 2006, 117-128.

Poblete Alday, Patricia "El hombre, ese fantasma: el yo como otredad en la narrativa de Roberto Bolaño”, Universum. 2004, vol.19, no.2, 186-197, en http://www.scielo.cl/scielo. (6 dic 2006). 
Quezada Iván, "La caída de Chile”. En: Patricia Espinosa (comp.). Territorios en fuga. Estudios críticos sobre la obra de Roberto Bolaño. Santiago de Chile: Frasis, 2003, p. 146.

Ríos Baeza, Felipe, La noción de margen en la narrativa de Roberto Bolaño. Tesis doctoral. Universidad Autónoma de Barcelona, 2011.

Ríos, Valeria de los, "Cartografía salvaje: mapa cognitivo y fotografías en la obra de Bolaño”, Taller de Letras, 41, 2007, 69-81. (También en: Bolaño salvaje)

Rodríguez Freire, Raúl, “El viaje del último Ulises. Bolaño y la figuración alegórica del infierno", "Fuera de quicio”. Sobre Bolaño en el tiempo de sus espectros, R. Rodríguez Freire, ed., Santiago, Ripio ediciones, 2012, 135-167.

Rojas Pachas, Daniel, "El discurso hipertextual como estrategia para la constitución de una memoria universal en la narrativa de Roberto Bolaño”, La Santísima Trinidad de las Cuatro Esquinas, noviembre 2009, año 1, n XII, Arica.

Rojo, Grínor, "Bolaño y Chile”, Anales de Literatura Chilena, 5:5, Dic 2004, 201-211. Sepúlveda, Magda, "La risa de Bolaño: el orden trágico de la literatura en 2666", Roberto Bolaño La experiencia del abismo, Fernando Moreno coord., Santiago, Ed. Lastarria, 2011, 233-242.

Solotorevsky Myrna, “Amberes y La pista de hielo, dos novelas de Bolaño, dos estéticas contrarias", Roberto Bolaño La experiencia del abismo, Fernando Moreno coord., Santiago, Ed. Lastarria, 2011, 97-106.

Solotorevsky Myrna, "El "espesor escritural” en dos cuentos de Roberto Bolaño: "Últimos atardeceres en la tierra" y "Dentista"”, Revista Laboratorio-UDP, n 2, otoño 2010, en: www.revistalaboratorio.cl/, (3 abr 2011). 


\section{Bibliografía general:}

AAVV "Declaración de Principios de la Junta Militar Chilena en 1974" (1974) en http://www.archivochile.com.

AAVV, Boletín 12 (2005) del Centro de Estudios de Teoría y Crítica Literaria, Facultad de Humanidades y Artes, Rosario, 7-77.

Achugar, Hugo "La historia y la voz del otro". La voz del otro: Testimonio, subalternidad y verdad narrativa. John Beverley y Hugo Achugar (editores). Lima y Pittsburgh, Latinoamericana Editores, 49-71, 1992.

Adorno Theodor W. "La educación después de Auschwitz" (Radio de Hesse el 18 de abril de 1966), disponible en: http://www.carpetashistoria.fahce.unlp.edu.ar

Adorno, Theodor, "Lukács y el equívoco del realismo" en VV AA Polémica sobre el realismo, Barcelona, Ediciones Buenos Aires, 1982.

Agambem, Giorgio, Lo que queda de Auschwitz. El archivo y el testigo. Homo sacer III, Valencia: Pretextos, 2000.

Agambem, Giorgio. ¿Qué es un campo?, enero de 1995, publicado en el número 1 de la revista Sibila. (En http://www.elcultural.com/eva/literarias/agamben)

Aira, César, Fragmento de un diario en los Alpes, Rosario, Beatriz Viterbo, 2004.

Alberca, Manuel, El pacto ambiguo. De la novela autobiográfica a la autoficción, Madrid, Biblioteca Nueva, 2007.

Amar Sánchez, Ana María, El relato de los hechos. Rodolfo Walsh: testimonio y escritura,

Rosario, Beatriz Viterbo, 1992.

Amar Sánchez, Ana María, Instrucciones para la derrota. Narrativas éticas y políticas de perdedores, Barcelona, Anthropos, 2010.

Amar Sánchez, Ana María, Juegos de seducción y traición. Literatura y cultura de masas, Rosario, Beatriz Viterbo, 2000

Amícola, José “Autoficción: una polémica vista desde los márgenes (Borges, Gombrowicz, Copi, Aira)", Olivar, 9: 12, 182-197, 2008.

Amícola, José , "Perlongher: memoria, luto y melancolía", VII Congreso Internacional Orbis Tertius, La Plata, 2009, Actas en www.orbistertius.unlp.edu.ar

Amícola, José, Autobiografía como autofiguración. Estrategias discursivas del yo y cuestiones de género. Rosario, Beatriz Viterbo Editora, 2008b.

Anderson Imbert, Enrique Teoría y técnica del cuento, Buenos Aires, Marymar, 1979. 
Ansaldi, Waldo. Las dictaduras del Cono Sur y las transiciones a la democracia hasta la actualidad (1964-2005). La historia reciente como desafío a la investigación y pensamiento en Ciencias Sociales, CAICYT CONICET. Disponible en: $<$ http://recursos.caicyt.gov.ar>, Argentina, 2010.

Arán, Pampa O. El fantástico literario. Aportes teóricos. Córdoba, Narvaja, 1999.

Arendt, Hannah Eichmann en Jerusalén. Un estudio sobre la banalidad del mal, Barcelona, Lumen, 2003.

Arendt, Hannah Sobre la violencia, Madrid, Alianza, 2006.

Arfuch, Leonor: "Cronotopías de la intimidad", en Leonor Arfuch (compiladora): Pensar este tiempo Espacios, afectos, pertenencias, Buenos Aires, Paidós, 2005.

Arfuch, Leonor: El espacio autobiográfico. Dilemas de la subjetividad contemporánea. Buenos Aires, Fondo de Cultura Económica, 2002.

Auerbach, Erich, Mimesis: La realidad en la literatura, México, Fondo de Cultura Económica, 1950.

Avelar, Idelber, "Alegoría y posdictadura: Notas sobre a memoria del mercado", Revista de crítica cultural 14, junio 1997, 22-27.

Avelar, Idelber, Alegorías de la derrota: La ficción postdictatorial y el trabajo del duelo, Santiago, Cuarto Propio, 2000.

Avelar, Idelber. "Bares desiertos y calles sin nombres: Literatura y experiencia en tiempos sombríos", Revista de crítica cultural 9, noviembre 1994, 37-43.

Avellaneda, Andrés, "Lecturas de la historia y lecturas de la literatura en la narrativa argentina de la década del ochenta" en Memoria colectiva y políticas del olvido, Buenos Aires, Beatriz Viterbo, 1997, 141-184.

Barrenechea, Ana María, (1957) La expresión de la irrealidad en la obra de Borges, Buenos Aires, CEAL, 1984.

Barrenechea, Ana María, "La crisis del contrato mimético en los textos contemporáneos", Revista Iberoamericana, vol. XLVIII, nº 118-119, enero-junio1982, 377-381.

Barrenechea, Ana María, La literatura fantástica en Argentina. México, Imprenta Universitaria, 1957.

Barthes Roland (1968) "La muerte del autor", El susurro del lenguaje, Barcelona, Paidós, 1987.

Barthes, Roland (1980) La cámara lúcida, Barcelona, Paidós, 1989. 
Barthes, Roland "Introducción al análisis estructural de los relatos", en AAVV, Análisis estructural del relato, México, Coyoacán, 1998.

Barthes, Roland, "El efecto de lo real", en AA VV Polémica sobre el realismo, Barcelona, Ediciones Buenos Aires, 1982.

Barthes, Roland, "Lección inaugural", El placer del texto y Lección inaugural. México, Siglo XXI, 1986.

Barthes, Roland, El grado cero de la escritura, México, Siglo XXI, 1973.

Bartra, Roger, El mito de la melancolía: literatura y ciencia en el Siglo de Oro, México, Universidad Iberoamericana, 1998, en http://www.fractal.com.mx

Basile, Teresa, "Aproximaciones a la posdictadura en el Cono Sur”, Dispositio/n XXIV 51, 2000, 115-133.

Basile, Teresa, "Nuevos escenarios: los intelectuales en el fin de siglo". Actas de IX Congreso de Literatura argentina, Río Cuarto, Facultad de Humanidades, 1997.

Bataille, Georges (1957) La literatura y el mal, Ediciones elaleph.com, 2000.

Benjamin, Walter (1936), "El narrador. Consideraciones sobre la obra de Nicolai Leskov", en Sobre el programa de la filosofía futura. Barcelona, Planeta-Agostini, 1986, 189-211.

Benjamin, Walter, "Tesis de filosofía de la historia” en Para una crítica de la violencia y otros ensayos, Madrid, Taurus, 1991.

Bernstein, Richard, El mal radical. Una indagación filosófica, Buenos Aires, Lilmod, 2004.

Bhabha Homi K (1990), "Narrating the Nation" en Fernández Bravo, Alvaro (Compilador), La invención de la Nación. Lecturas de la identidad de Herder a Homi Bhabha, Manantial, Buenos aires, 2000, 211-219.

Bianchi, Soledad, ¿La insoportable levedad...? (imágenes y textos, postdictadura y modernidad en Chile), Centro de investigaciones sociales, Universidad Arcis, $\mathrm{n}^{\mathrm{o}}$ 21, octubre 1997.

Bilbeny, Norbert, El idiota moral, Barcelona, Anagrama, 2003.

Borges, Jorge Luis (1948) "Prólogo" a La invención de Morel de Adolfo Bioy Casares, Disponible en: http://www.literatura.org/Bioy/Morelprologo.html (25 de julio 2012) Borges, Jorge Luis (2007) "El cuento policial” (Borges oral, 1979) en Obras completas 4, Buenos Aires, Emecé.

Borges, Jorge Luis, "Nueva refutación del tiempo". En Inquisiciones/ Otras inquisiciones. Buenos Aires, Debolsillo, 2012, 359-380. 
Borges, Jorge Luis, Historia universal de la infamia, Buenos Aires, DeBolsillo, 2011.

Borges, Jorge Luis, Inquisiciones/Otras inquisiciones, Buenos Aires, DeBolsillo, 2012.

Bourdieu, Pierre (1992) "La emergencia de una estructura dualista", "El mercado de los bienes simbólicos", en Las reglas del arte, Barcelona, Anagrama, 1995, 172-252.

Brescia Pablo y Evelia Romano, El ojo en el caleidoscopio, México, Universidad Autónoma de México, 2006.

Brescia, Pablo "La teoría del cuento desde Hispanoamérica", Actas XIII Congreso AIH, tomo III, 1998.

Brito, Cristián: "El género negro: su gestación anglosajona y colonización hispánica", en http://www.critica.cl/html/c_brito_09.htm

Brunner, José Joaquín “Tradicionalismo y modernidad en la cultura latinoamericana”, Escritos. Revista del Centro de Ciencias del Lenguaje, número 13-14, enero-diciembre, 1996, 301-333.

Brunner, José Joaquín, "Modernidad, democracia y cultura", Chile 2000, Santiago, Nueva Sociedad, 1988.

Burton, Robert, [1621] Anatomía de la melancolía, Buenos Aires, Espasa Calpe, 1947.

Calveiro, Pilar, Poder y desaparición: los campos de concentración en Argentina, Buenos Aires, Colihue, 2004.

Campra, Rosalba, Territorios De La Ficción: Lo Fantástico. Sevilla, Renacimiento, 2008 .

Cánovas, Rodrigo, Novela chilena, nuevas generaciones. El abordaje de los huérfanos, Santiago, Universidad Católica de Chile, 1997.

Capdevila, Analía, “Realismo, memoria, testimonio". En: Vallina, Cecilia (ed.): Crítica del testimonio. Ensayos sobre las relaciones entre memoria y relato. Rosario, Beatriz Viterbo, 2009, 132-148.

Carpentier, Alejo, "Prólogo", El reino de este mundo. Montevideo, Arca-Calicanto, 1966, 7-16.

Caruth, Cathy, Unclaimed Experience. Trauma, Narrative and History, Baltimore, Johns Hopkins UP, 1996.

Caruth, Cathy(ed). Trauma. Explorations in Memory. Baltimore, Baltimore, Johns Hopkins UP, 1995.

Catelli, Nora, En la era de la intimidad seguido de El espacio autobiográfico, Rosario, Beatriz Viterbo, 2006. 
Chartier Roger (1998) "Trabajar con Foucault: esbozo de una Genealogía de la “función-autor”, Signos Históricos I.1 (junio 1999), 11-27.

Chatellus, Adélaïde de (ed), El cuento hispanoamericano contemporáneo: Vivir del cuento, Paris, RILMA 2 -ADEHL, 2009.

Chiani Miriam, "Sobre el realismo en Marcelo Cohen", trabajo presentado en $I^{o}$ Congreso Regional del Instituto Internacional de Literatura Iberoamericana "Nuevas cartografías críticas: problemas actuales de la literatura iberoamericana”, junio de 2005, Rosario.

Collyer, Jaime, "Casus belli: todo el poder para nosotros", APSI, 415, Santiago., 24 febrero-8 marzo de 1992.

Colonna, Vincent, [1989]. L'autofiction (essai sur la fictionalisation de soi en Littérature), tesis para la obtención del grado de doctor de la École des Hautes Études en Sciences Sociales de París, Francia, 2004, disponible en: http://tel.archivesouvertes.fr

Contreras Sandra, Las vueltas de Aira, Rosario, Beatriz Viterbo, 2008.

Contreras, Sandra, “En torno al realismo”, Confines, n 17, diciembre 2005.

Cortázar, Julio, “Algunos aspectos del cuento”, Casa de las Américas, 2.15-16 (1962), en: Teorías del cuento I: Teorías de los cuentistas, Lauro Zavala (comp), México, UNAM- UAM-Xochimilco, 1993, 303-24.

Cortázar, Julio, "Del cuento breve y sus alrededores", Último round, México, Siglo XXI, 1969, 69-82.

Cortínez, Verónica, ed. Albricia. La novela chilena del fin del siglo, Santiago, Cuarto propio, 2000.

Cragnolini, Mónica B.: “Confesión y circuncisión: San Agustín en Derrida o ¿de qué sirve el amor que no se confiesa?", en Pensamiento de los confines 17, diciembre de 2005 .

Dalmaroni, Miguel "Lugones: La pulsión polémica”, Boletín/11 del Centro de Estudios de Teoría y Crítica Literaria, Diciembre de 2003.

Dalmaroni, Miguel, "El juicio del siglo: Leopoldo Lugones revisitado", Castilla. Estudios de Literatura, 1 (2010): 408-419.

Dalmaroni, Miguel, "La obra y el resto (literatura y modos de archivo)", Telar, n 7-8, año VI, 2009/2010, 9-30.

Dalmaroni, Miguel, La palabra justa, Santiago, Melusina, 2004.

Dalmaroni, Miguel, Una república de las letras, Rosario, Beatriz Viterbo, 2006. 
De Diego, José Luis, ¿Quién de nosotros escribirá el Facundo? Intelectuales y escritores en argentina (1970-1986), La Plata, Al margen, 2001.

De Man, Paul, "La autobiografía como desfiguración”, trad. de Ángel G. Loureiro, Suplementos Anthropos n 29, Barcelona, diciembre 1991, 113-118.

De Santis, Pablo, "Los ejes del policial argentino: melancolía y derrota", entrevista de Ezequiel Martinez, Revista N, Clarín, Buenos Aires, 2010.

Del Sarto, Ana, "Los afectos en los estudios culturales latinoamericanos. Cuerpos y subjetividades en Ciudad Juárez”, Cuadernos de literatura n 32, Julio-Diciembre 2012, 41-68.

Del Sarto, Ana, Sospecha y goce: una genealogía de la crítica cultural en Chile, Santiago, Cuarto propio, 2010.

Derrida, Jacques. Mal de archivo. Una impresión freudiana. Madrid, Trotta, 1997.

Díaz Eterovic, Ramón, "El neopolicial latinoamericano: del cuarto cerrado a las calles de la ciudad latinoamericana". Entrevistado por Freddy Vilches, Revista La negraNovela y cine negro, 2011, en línea: http://www.revistalanegra.cl/policial/careos

Díaz Eterovic, Ramón, "La narrativa policial chilena de los años 80 en adelante”, 2006, en línea http://gangsterera.free.fr/RepNPchilena.htm

Didi-Huberman, Georges, "El archivo arde", traducción de "Das Archivo brennt" (en: Georges Didi-Huberman y Knut Ebeling (eds.). Das Archiv brennt, Berlin: Kadmos, pp. 7-32.) por Juan Antonio Ennis, disponible en: filologiaunlp.wordpress.com. (3 abr 2012)

Didi-Huberman, Georges. Imágenes pese a todo. Memoria visual del Holocausto, Barcelona, Paidós, 2004.

Donoso, Jaime, Narrativas durante y después de la dictadura experiencia, comunidad y narración, Pittsburg, University of Pittsburg, 2006.

Dosse, François, El arte de la biografía: entre historia y ficción, México, Universidad Iberoamericana, 2007.

Dossier "1973-1998: Fracturas de la memoria, convulsiones del sentido": Eltit, Diamela "Las dos caras de la moneda"; Richard, Nelly "Servidumbre, mercado y éxtasis"; Morales Leonidas "Cartas de petición"; Victoriano Felipe "Lo desaparecido, su espera"; Galende "La izquierda entre el duelo, la melancolía y el trauma" Revista de crítica cultural 17, noviembre 1998, 28-47.

Dossier "Historia y memoria: El estallido 'Pinochet": Villalobos-Ruminott, Sergio “Chile y postdictadura: El escándalo Pinochet como síntoma de un país atribulado"; 
Vicuña, Miguel "El grado cero de la contingencia"; Pérez Villalobos, Carlos "Tono y dignidad"; Jocelyn-Holt, Alfredo, Julio Pinto y Gabriel Salazar "Debatir la historia", Revista de crítica cultural 18, junio 1999, 20-39.

Dossier "La memoria herida": Schmucler, Héctor "Las exigencias de la memoria"; Peña, Carlos "Derecho, moralidad y justicia"; Richar, Nelly "Las confesiones de un torturtador y su (abusivo) montaje periodístico"; Avelar, Idelber "La muerte y la doncella o la hollywoodización de la tortura"; Guerrero Manuel "El por qué de la imposible Historia Nacional"; Galende, Federico "El desaparecido, la desdicha del testigo". Revista de crítica cultural 22, junio 2001, 8-34.

Dossier: Lo que brilla por su ausencia": Richard, Nelly "Lo impúdico y lo público"; Lombardo, Francesca “Cuerpo, violencia y traición”; Eltit, Diamela "Vivir ¿dónde?”. (1995). Revista de crítica cultural 11, noviembre 1995, 29-43.

Eco, Umberto, Obra abierta, Barcelona, Ariel, 1990.

Felman Shoshana y Dori Laub, Testimony: Crises of Witnessing in Literature, Psychoanlaysis, and History, New York: Routledge, 1992, 68-69.

Ferro, Rafael, "La narrativa policial latinoamericana. Una encrucijada de senderos que se bifurcan e intersectan”, De la literatura y los restos, Buenos Aires, Liber, 2009.

Filer, Malva, "Funciones de lo fantástico en la narrativa argentina posterior al proceso: La ciudad ausente de Ricardo Piglia”. En: Signos literarios y lingüísticos, vol. II, $\mathrm{n}^{\mathrm{o}} 2$, julio-diciembre, 2000, 153-159

Fischer, Ersnt, "El problema de lo real en el arte moderno", en AAVV, Polémica sobre el realismo, Barcelona, Ediciones Buenos Aires, 1982.

Flores Angel, "Magical Realism in Spanish American fiction", Hispania, vol. XXXVIII, no 2, 1955, 187-192.

Foster, Hal, "The Return of the Real", The Return of the Real, October Books/MIT, 1996.

Foucault Michel (1969), “¿Qué es un autor?”, Trad. de Silvio Mattoni. Córdoba, Ediciones Literales, 2010.

Franco Marina y Florencia Levín (comps.) Historia reciente: perspectivas y desafios para un campo en construcción, Buenos Aires, Paidós, 2007.

Franken, Clemens, Crimen y verdad en la novela policial chilena actual, Santiago, Universidad de Santiago de Chile, 2003.

Franz Carlos, "Nueva narrativas, viejas picas", Carlos Olivares ed., Nueva narrativa chilena, Santiago, Lom, 1997,107-113. 
Freud, Sigmund, ([1917] 2000). "Duelo y melancolía", Obras completas. Vol XIV, Buenos Aires, Amorrurtu.

Freud, Sigmund, y Hoffman, E. El hombre de arena / Lo siniestro, Buenos Aires, JCE Ediciones, 2004.

Fröhlicher, Peter y Georges Güntert, Teoría e interpretación del cuento, Bern, Peter Lang, 1996.

Fuentes, Carlos, Los 68: París-Praga-México, Buenos Aires, Debate, 2005.

Fuguet Alberto y Sergio Gómez comp. (1996) McOndo, Barcelona, GrijalboMondadori.

Fuguet, Alberto, "21 notas sobre la nueva narrativa", Carlos Olivares ed., Nueva narrativa chilena, Santiago, Lom, 1997, 119-122.

Fuguet, Alberto y Sergio Gómez, "Prólogo", McOndo, Barcelona, Grijalbo-Mondadori, 1996.

Galende, Federico, "La izquierda entre el duelo, la melancolía y el trauma" Revista de crítica cultural 17, noviembre 1998, 28-47.

Gandolfo, Elvio, "La narrativa policial”, El libro de los géneros, Bs As, Grupo Editorial Norma, 2007.

García Ramos, Arturo, El cuento fantástico en el Río de la Plata. Madrid, La mirada malva, 2010.

García-Corrales Guillermo y Pino, Mirian. Poder y crimen en la narrativa chilena contemporánea. Las novelas de Heredia, Santiago, Mosquito Editores, 2002.

Gasparini, Philippe , Est-il je? Roman autobiographique et autofiction, Paris, Seuil, 2004.

Genette, Gérard, Palimpsestos, Madrid, Taurus, 1989.

Gilman, Claudia, Entre la pluma y el fusil. Debates y dilemas del escritor revolucionario en América latina, Buenos Aires, Siglo XXI Editores Argentina, 2003.

Giordano Alberto "Cultura de la intimidad y giro autobiográfico en la literatura argentina actual", Pensamiento de los confines, n. 21, Diciembre de 2007.

Giordano, Alberto El giro autobiográfico, Buenos Aires, Mansalva, 2008.

Giordano, Alberto Una posibilidad de vida. Escrituras intimas. Rosario, Beatriz Viterbo, 2006.

Girard, René, El chivo expiatorio, Barcelona: Anagrama, 1986.

Girard, René, La violencia y lo sagrado, Barcelona: Anagrama, 2005. 
Goloboff Mario, “Cortázar revisitado”, Orbis Tertius, año IV, n 7, 4-10. Disponible en http://www.orbistertius.unlp.edu.ar. 2000, (25 jul 2012).

González Rodríguez, Sergio, Huesos en el desierto, Barcelona, Anagrama, 2002.

Gramuglio, María Teresa (comp.) El imperio realista, Buenos Aires, Emecé, 2002.

Gramuglio, Maria Teresa, "La construcción de la imagen", en Tizón y otros, La escritura argentina, Santa Fe, Universidad Nacional del Litoral y Ed. La Cortada, 1992, $37-64$.

Gramuglio, María Teresa: "La crítica de la literatura. Un desplazamiento" en Punto de Vista, No 60, XXI, 60, Buenos Aires, abril de 1998, 3-7.

Groppo, Bruno y Patricia Flier compiladores. La imposibilidad del olvido. Recorridos de la memoria en Argentina, Chile y Uruguay. La Plata, Al Margen, 2001.

Groppo, Bruno, “Traumatismos de la memoria e imposibilidad del olvido en los países del Cono Sur", en Bruno Groppo y Patricia Flier compiladores. La imposibilidad del olvido. Recorridos de la memoria en Argentina, Chile y Uruguay. La Plata, Al Margen, 2001 .

Gundermann, Christian, Actos melancólicos: formas de resistencia en la posdictadura argentina, Rosario, Beatriz Viterbo Editora, 2007.

Hemigway, Ernest (1953), “El principio del iceberg”, entrevistado por George Plimpton para The Paris Review, en: Zavala, Lauro (ed) Teorías del cuento III. Poéticas de la brevedad, UAM, México, 1997.

Huyssen Andreas, "La cultura de la memoria: medios, políticas y amnesia", Revista de crítica cultural 18, junio 1999, 8-15.

Imbert, Gérard, Los escenarios de la violencia, Barcelona, Icaria, 1992.

Jackson, Rosemary, Fantasy: literatura y subversión, Buenos Aires, Catálogos, 1986.

Jakob Nielsen, Multimedia and Hypertext. The Internet and Beyond, San Diego, Academic Press, 1995.

Jakobson, Roman, "El realismo artístico", en AAVV Polémica sobre el realismo, Barcelona, Ediciones Buenos Aires, 1982.

Jelin, Elizabeth, "Exclusión, memorias y luchas políticas", Cultura, política y sociedad Perspectivas latinoamericanas. Daniel Mato. CLACSO, Consejo Latinoamericano de Ciencias Sociales, Ciudad Autónoma de Buenos Aires, Argentina, 2005.

Jitrik, Noé, Debate en "Ciclo de nueva narrativa latinoamericana", AAVV, Actual narrativa latinoamericana. La Habana, Casa de las Américas, 1970. 
Jocelyn-Holt, Alfredo, "Menos es más, o la historia que falta", Revista de Crítica Cultural, $\mathrm{n}^{\mathrm{o}} 18$, junio 1999.

Judge, William, "Mesmerismo" en http://www.upasika.com/docs/teosofia.pdf

Kamenszain, Tamara La boca del testimonio. Lo que dice la poesía. Buenos Aires, Norma, 2007.

Klein, Irene, La ficción de la memoria: la narración de historias de vida, Buenos Aires, Prometeo, 2007.

Kohan Martín, "Dos recientes lecturas modernas" y Sandra Contreras "Intervención”, Boletín/11 del Centro de Estudios de Teoría y Crítica Literaria, Rosario, diciembre 2003.

Kozak, Claudia (comp.) Deslindes. Ensayos sobre la literatura y sus límites en el siglo XX. Rosario, Beatriz Viterbo Editora, 2006.

Lancelotti, Mario, De Poe a Kafka para una teoría del cuento, Buenos Aires, Eudeba, 1974.

Laddaga, Reinaldo, Espectáculos de realidad. Ensayo sobre la narrativa latinoamericana de las últimas décadas. Rosario, Beatriz Viterbo Editora, 2007.

Laddaga, Reinaldo, Estética de la emergencia. La formación de otra cultura de las artes. Buenos Aires, Adriana Hidalgo Editora, 2006.

Lagmanovich David, Códigos y rupturas: textos hispanoamericanos, Roma, Bulzoni, 1988.

Landow George P., Hypertext. The Convergence of Contemporary Critical Theory Baltimore, 1992, http://www.cyberartsweb.org, 164-168 (17 oct 2011).

Leal Luis, "El realismo mágico en la literatura hispanoamericana", Cuadernos americanos, $\mathrm{n}^{\circ}$ 153, julio-agosto, 1967, 230-235.

Lejeune, Philippe., El pacto autobiográfico y otros estudios, coord. Angel G. Loureiro, Madrid, Megazul-Endymión, 1994.

Levi Primo, Los hundidos y los salvados, Barcelona, Muchnik, 1995.

Link, Daniel comp. El juego de los cautos. Literatura policial de Edgar A. Poe a P.D. James, Buenos Aires, La Marca, 2003.

List Arzubide Germán. La revolución literaria: el movimiento estridentista, México, Federación Editorial Mexicana S. A., 1988.

Louis, Annick, "Del rol de la delimitación del corpus en la teoría literaria. A propósito de la Introducción a la literatura fantástica de Tzvetan Todorov y de la crítica literaria hispanoamericana", Badebec, vol. 2, no 3, 2012, 118-142. 
Louis, Annick, 2012, "Del rol de la delimitación del corpus en la teoría literaria. A propósito de la Introducción a la literatura fantástica de Tzvetan Todorov y de la crítica literaria hispanoamericana", Badebec, n 3 vol 2, Rosario, 118-142.

Löwy, Michael, Walter Benjamin: Aviso de incendio. Una lectura de las tesis "Sobre el concepto de historia”, Buenos Aires, Fondo de cultura económica, 2002.

Ludmer, Josefina, "El resto del texto", Literal, 1, 1973, 47-52.

Lukács, Georg, “¿Narrar o describir? Contribución a la discusión sobre el naturalismo y el formalismo", en Goldman, Lucien y otros, Literatura y sociedad, Buenos Aires, CEDAL, 1978.

Lukács, Georg, “Realismo ¿experiencia socialista o naturalismo burocrático?”, en VV AA Polémica sobre el realismo, Barcelona, Ediciones Buenos Aires, 1982.

Mandel, Ernest, Crimen delicioso. Historia social del relato policiaco, Buenos Aires, RyR, 2011.

Maples Arce, Manuel, “Soberana juventud”, Nivel, II época, México DF, n. 86, 1970.

Martínez, Guillermo, "El cuento como sistema lógico", Con V de Vian, $\mathrm{n}^{\circ} 32$, febrero, 1998.

Mate, Reyes, "Memoria e historia: dos lecturas del pasado" en Letras libres, febrero de 2006, 44-48.

Mattalía, Sonia, La ley y el crimen. Usos del relato policial en la narrativa argentina (1880-2000), Madrid, Iberoamericana, 2008.

Mauro Castellarín, Teresita (coord.) Dossier: "El enigma, el crimen, la pesquisa: variaciones, reivenciones $\mathrm{y}$ simulacros en torno al relato policial en Hispanoamérica, Anales de Literatura Hispanoamericana, vol. 36, 2007, 19-121.

Menton Seymour (ed.), El cuento hispanoamericano. Antología crítico-histórica, México, Fondo de Cultura Económica, 1986.

Metz, Johannes Baptist, Por una cultura de la memoria, Anthropos, Barcelona. 1999.

Millares, S. y Madrid, A, "Última narrativa chilena: la escritura del desencanto" Cuadernos Hispanoamericanos 482-83: 1990, 113-122.

Molloy, Sylvia, Acto de presencia. La escritura autobiográfica en Hispanoamérica, México, Fondo de Cultura Económica, 1996.

Monterroso, Augusto, Cuentos, fábulas y Lo demás es silencio. México, Alfaguara, 1999. 
Mora, Gabriela, "Notas teóricas en torno a la colección de cuentos integrados", Brescia y Romano, El ojo en el caleidoscopio, México, Universidad Autónoma de México, 2006, 53-75.

Morales, Leonidas, La escritura de al lado. Géneros referenciales, Santiago, Cuarto propio, 2001.

Moreiras, Alberto, "Posdictadura y reforma del pensamiento", Revista de crítica cultural 7, noviembre 1993, 26-35.

Moulian, Tomás, "Olvido y consenso", Revista de crítica cultural 13, noviembre 1996, 44-45.

Moulian, Tomás, Chile Actual: Anatomía de un mito. Santiago de Chile, Ediciones Lom/Arcis, 1997.

Nesset, Kirk, The Stories of Raymond Carver. A Critical Study, Athens Ohio, Ohio University Press. 1995.

Olivárez, Carlos (ed.), Nueva narrativa chilena, Santiago, Lom, 1997.

Orellana, Carlos, "La cultura chilena en el momento del cambio" Cuadernos Hispanoamericanos 482-483, 1990, 49-54.

Osorio, Nelson, Manifiestos, proclamas y polémicas de la vanguardia literaria hispanoamericana, Caracas, Ayacucho, 1988.

Oyarzún Pablo, "Duelo y alegoría de la experiencia”, Revista de crítica cultural 21, noviembre 2000, 68-69.

Panesi, Jorge (1994) "Política y ficción o acerca del volverse literatura de cierta sociología argentina", Boletín/4 del Centro de Estudios de Teoría y Crítica Literaria, Rosario, abril 1995.

Pellicer, Rosa, "Críticos detectives y críticos asesinos. La busca del manuscrito en la novela policíaca hispanoamericana (1990-2006)", Anales de Literatura Hispanoamericana, vol. 36, Universidad Complutense de Madrid, 2007.

Pellicer, Rosa, "Notas sobre literatura fantástica rioplatense (del terror a los extraño)", CIF T XI, Fasc 1 y 2, 1985, 31-58.

Perez, Carlos V, Adriana Valdés y Nelly Richard, "Memoria, arte y política", Revista de crítica cultural 22, junio 2001, 46-53.

Peris Blanes, Jaume La imposible voz. Memoria y representación de los campos de concentración en Chile: la posición del testigo, Santiago, Cuarto Propio, 2005.

Piglia, Ricardo, "La ficción paranoica”, Clarín, 10 octubre 1991. 
Piglia, Ricardo, "Lo negro del policial”, en: Link, Daniel comp., El juego de los cautos. Literatura policial de Edgar A. Poe a P.D. James, Buenos Aires, La Marca, 2003.

Piglia, Ricardo, "Tesis sobre el cuento", "Nuevas tesis sobre el cuentos", Formas breves, Barcelona, Anagrama, 2000.

Piglia, Ricardo, Prólogo a Las Fieras, Antología del género policial argentino, Buenos Aires, Alfaguara, 1999.

Planells, Antonio, "El realismo mágico Hispanoamericano ante la crítica”, Chasqui, vol XVII, 1, mayo, 1988.

Poe, Edgar Allan. (1844) "Revelación mesmérica" en www.ciudadseva.com

Poe, Edgar Allan, "Filosofía de la composición", Ensayos y críticas, Trad. Julio Cortázar. Madrid, Alianza 1973, 65-79.

Poe, Edgar Allan, "The Imp of the Perverse", The Portable Edgar Allan Poe, London, Penguin Classics, 2006, 202-207.

Poniatowska, Elena La noche de Tlatelolco, México, Era, 1971.

Premat, Julio, Héroes sin atributos: figuras de autor en la literatura argentina, Buenos Aires, Fondo de Cultura Económica, 2009.

Premat, Julio, La dicha de Saturno, Rosario, Beatriz Viterbo, 2002.

Prieto, Adolfo, La literatura autobiográfica argentina, Buenos Aires, Jorge Alvarez, 1966.

Promis, José, La novela chilena del último siglo, Santiago, La Noria, 1993.

Rama, Ángel, "Fantasmas, delirios y alucinaciones". En AAVV, Actual narrativa latinoamericana, La Habana, Casa de las Américas, 1970, 39-65.

Rama, Ángel, 1970, "Fantasmas, delirios y alucinaciones", AAVV, Actual narrativa latinoamericana, La Habana: Casa de las Américas.

Resina, Joan Ramon El cadáver en la cocina. La novela criminal en la cultura del desencanto, Barcelona, Anthropos, 1999.

Richard, Nelly, “Lo político y lo crítico en el arte: ¿quién le teme a la neovanguardia?". pensamiento de los CONFINES número 15, diciembre 2004.

Richard, Nelly (editora), Políticas y estéticas de la memoria, Santiago, Cuarto propio, 2000 .

Richard, Nelly "Lo impúdico y lo público", Revista de Crítica Cultural, n 11, Noviembre 1995.

Richard, Nelly, "Cultura, política y democracia”, Revista de crítica cultural 5, año3, julio 1992, 5-8. 
Richard, Nelly, "Las reconfiguraciones del pensamiento crítico en la posdictadura”, en Carlos A. Jáuregui, Juan P. Dabove (eds), Heterotopias: narrativas de identidad y alteridad latinoamericana. Pittsburg, PA: Instituto Internacional de Literatura Iberoamericana, 2003, 287.

Richard, Nelly, "Lo político y lo crítico en el arte: ¿quién le teme a la neovanguardia?”, pensamiento de los Confines, número 15, diciembre 2004.

Richard, Nelly, La estratificación de los márgenes. Santiago, Zegers, 1989.

Richard, Nelly, La insubordinación de los signos. Santiago, Cuarto Propio, 1994.

Richard, Nelly, Residuos y Metáforas (Ensayos de crítica cultural sobre el Chile de la Transición). Santiago de Chile, Editorial Cuarto Propio, 1998.

Roas, David, "Más allá de los límites del lenguaje. Lo fantástico como subversión discursiva", Elton Honores (coord.) Lo fantástico en Hispanoamérica. Lima, Cuerpo de la metáfora, 2011, 263-272.

Rodríguez Monegal Emir [1952] Narradores de esta América, Buenos Aires, Alfa Argentina, 1976a.

Rodríguez Monegal Emir, "Borges: una teoría de la literatura fantástica". Revista Iberoamericana, abril-junio, 1976b, 177-189.

Rojas Sergio, "De esas pequeñas fantasías en plena tempestad", Revista de crítica cultural 16, junio 1998, 36-40.

Said Edward (1993), Representaciones del intelectual, Barcelona, Paidós Studio, 1996.

Said, Edward, Beginnings. Intention and Method, New York, Columbia University Press, 1985.

Salinas, Alexander. "Novela negra y memoria en Latinoamérica", Poligramas, ${ }^{\circ} 27$, junio 2007.

Saltzman, Arthur M., Understanding Raymond Carver, Columbia, University of South Carolina Press, 1988.

Sánchez Prado, Ignacio (ed.), América Latina en la literatura mundial, Pittsburg, IILI, 2006.

Sanguinetti, Edoardo (1969). "Sociología de la vanguardia", Literatura y sociedad, problemas de metodología en sociología de la literatura, Barcelona, Ediciones Martínez Roca, 1969, 13-33.

Santa Cruz, Guadalupe, "Impunidad inmunidad (economía de la violencia)”, Revista de crítica cultural 10, mayo 1995, 17-19. 
Sarlo Beatriz, “AArcaicos o marginales? Situación de los intelectuales en el fin de siglo", Revista de crítica cultural 8, mayo 1995, 8-13.

Sarlo, Beatriz, “Intelectuales: ¿escisión o mímesis?”. Punto de Vista número 25, Buenos Aires, diciembre 1985.

Sarlo, Beatriz, "Literatura e historia”, Boletín de historia social, n 3, La Plata, 1991, 25 36.

Sarlo, Beatriz, "Política, ideología y figuración literaria", AAVV Ficción y política. La narrativa argentina durante el proceso militar, Buenos Aires, Alianza Editorial, 1987.

Sarlo, Beatriz, Tiempo pasado. Cultura de la memoria y giro subjetivo. Una discusión, Buenos Aires, Siglo XXI, 2005.

Scantlebory, Marcia, "Paco Ignacio Taibo II: la novela negra es la gran novela social de fin de milenio", Caras, 2000, en línea, www.caras.cl

Schneider Luis Mario. El estridentismo o una literatura de la estrategia. México, INBA, 1970.

Schwartz Jorge, Las vanguardias literarias latinoamericanas. Textos programáticos y críticos, México, Fondo de Cultura Económica, 2006.

Schwob, Marcel, Vidas imaginarias, Buenos Aires, CEAL, 1980.

Sepúlveda, Magda, "Del género policial”, en Rodrigo Cánovas ed., Novela chilena, nuevas generaciones. El abordaje de los huérfanos, Santiago, Universidad Católica de Chile, 1997.

Segato, Rita, La escritura en el cuerpo de las mujeres asesinadas en Ciudad Juárez: territorio, soberanía y crímenes de segundo estado, México, Colección VocesUniversidad del Claustro de Sor Juana, 2006.

Song Rosi "En torno al género negro: ¿La disolución de una conciencia ética o la recuperación de un nuevo compromiso político?", Revista Iberoamericana, Vol. LXXVI, Núm. 231, Abril-Junio 2010, 459-475.

Sontag, Susan, Sobre la fotografía, México, Alfaguara, 2006.

Sorel, Georges, Reflexiones sobre la violencia, Buenos Aires, La Pléyade, 1978.

Spengler, Oswald, La decadencia de occidente, Bosquejo de una morfología de la Historia Universal, Edición original: 1918. Edición electrónica - Buenos Aires 2006, www.laeditorialvirtual.com.ar.

Speranza, Graciela, "Magias parciales del realismo", en milpalabras letras y artes en revista, $\mathrm{n}^{\mathrm{o}} 2$, verano de 2001 . 
Spiller Roland (2009) "Roberto Bolaño: fracasar con éxito o navigare necessum est", en Yvette Sánchez / Roland Spiller (Eds.), Poéticas del fracaso, Tübingen, Gunter Narr Verlag, 143-173.

Starobinski, Jean, La relación crítica [1970], Buenos Aires, Ediciones Nueva Visión, 2008 .

Subercaseaux, Bernardo, "Vanguardia heroica y recepción nacionalista", Athenea Concepción, 501, 2010, 53-71.

Thayer, Willy, "El golpe como consumación de la vanguardia", en "Arte y dictadura en América Latina", Confines, n 15, diciembre de 2004.

Todorov Tzvetan (1974) "Topología del relato policial" en El juego de los cautos. La literatura policial, comp. Daniel Link, Buenos Aires, La Marca, 1996.

Todorov, Tzvetan, Introducción a la literatura fantástica, Buenos Aires, Tiempo contemporáneo, 1974.

Toro, Vera; Schlickers, Sabine; Luengo, Ana (2010) "La auto(r)ficción: modelizaciones, problemas, estado de la investigación", Toro, Vera; Schlickers, Sabine; Luengo, Ana (eds.), La obsesión del yo - La auto(r)ficción en la literatura española y latinoamericana. Madrid, Iberoamericana, 2010, 7-29.

Trelles Paz, Diego, "Novela policial alternativa hispanoamericana (1960-2005)", Aisthesis, no 40, 2006, 79-91.

Umberto Eco, Interpretación y sobreinterpretación, Gran Bretaña, Cambridge University Press, 1995

Valcárcel, Eva, "El cuento hispanoamericano. Aproximación teórica”, en Eva Valcárcel (ed.), El cuento hispanoamericano del siglo XX. Teoría y práctica, A Coruña, Universidade, 1997, 21-29.

Vallejo César (1939) "Intensidad y altura”, Obra poética completa. Ed. Enrique Ballón Aguirre, Caracas, Biblioteca Ayacucho, 1979, 32.

Verdevoye, Paul, "Tradición y trayectoria de la literatura fantástica en el Río de la Plata", Anales de la literatura hispanoamericana, $\mathrm{n}^{\circ}$ 9, 1980, 283-303.

Vezzetti, Hugo, "Representaciones de los campos de concentración en la Argentina", Punto de vista 68, diciembre de 2000, 13-17.

Vezzetti, Hugo, "Variaciones de la memoria social". Punto de Vista número 56, Buenos Aires, diciembre 1996.

Vezzetti, Hugo, Sobre la violencia revolucionaria. Memorias y olvidos, Buenos Aires, Siglo Veintiuno editores, 2009. 
Vezzetti, Hugo. Pasado y presente, Buenos Aires, Siglo XXI, 2002.

Villalobos-Ruminott, Sergio, "El escándalo Pinochet como síntoma de un país atribulado", Revista de Crítica Cultural, n 18, junio 1999.

Volek Emil, “Análisis e interpretación de El reino de este mundo de Alejo Carpentier". En: Giacoman, Helmy (comp.): Homenaje a Alejo Carpentier, Nueva York, Las Américas, 1970, 147-178.

Volek, Emil, “José Martí, Nuestra (Macondo) América”, Universum, no 22, vol. 1, Universidad de Talca, Chile, 2007, 300-317.

Waldman, Gilda, "Memoria y política: consideraciones en torno a la nueva narrativa chilena" en Hispamérica 87 año XXIX, 2000, 51-64.

Wierviorka, Annette, The Era of the Witness, New York, Cornell University Press, Jared Stark translator, 2006.

Xirau, Ramón, “Crisis del realismo”. En: Fernández Moreno, César (coord.): América Latina en su literatura. México, Siglo Veintiuno / Unesco, 1972, 185-203.

Yerushalmi, Yosef, "Reflexiones sobre el olvido", en AAVV Usos del olvido. Comunicaciones al Coloquio de Royaumont, Buenos Aires: Nueva Visión, 1996, 13-50. Zaid Gabriel, “Tres conceptos de obra completa”, Letras libres, mayo 2004. Zambrano, María, La confesión: género literario, Madrid, Siruela, 1995. 